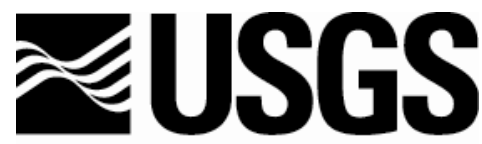

science for a changing world

\title{
Quantity, Quality, and Support for Research in the U.S. Fish and Wildlife Service: An Organizational Assessment
}

By Joan M. Ratz, Phadrea D. Ponds, Jennefer R. Neilson, Joyce Liverca, and Berton Lee Lamb

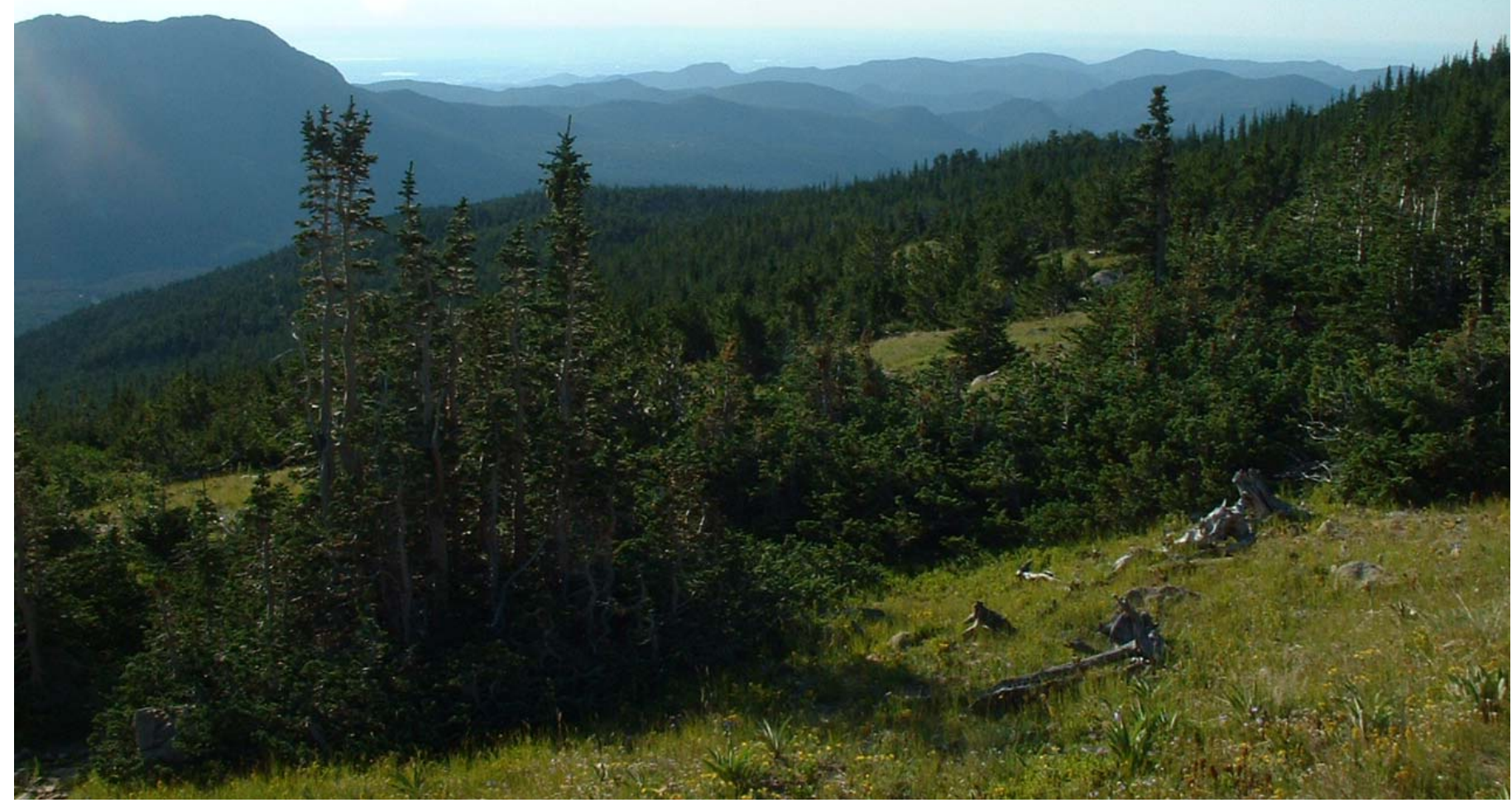

Any use of trade, firm, or product names is for descriptive purposes only and does not imply endorsement by the U.S. Government

\section{Open-File Report 2005-1391}

U.S. Department of the Interior

U.S. Geological Survey 
Cover photo courtesy of Katherine D. Wundrock 


\section{U.S. Department of the Interior \\ GALE A. NORTON, Secretary}

\section{U.S. Geological Survey \\ P. Patrick Leahy, Acting Director}

\section{U.S. Geological Survey, Reston, Virginia 2005}

This report is available online at:

http://www.fort.usgs.gov/products/publications/21528/21528.pdf

For product and ordering information:

World Wide Web: http://www.usgs.gov/pubprod

Telephone: 1-888-ASK-USGS

For more information on the USGS - the Federal source for science about the Earth, its natural and living resources, natural hazards, and the environment:

World Wide Web: http://www.usgs.gov

Telephone: 1-888-ASK-USGS

Suggested citation:

Ratz, J.M., Ponds, P.D., Neilson, J.R., Liverca, J., and Lamb, B.L., 2005, Quantity, quality, and support for research in the U.S. Fish and Wildlife Service: An organizational assessment: U.S. Geological Survey, Biological Resources Discipline, Open-File Report 2005-1391, 173 p.

Although this report is in the public domain, permission must be secured from the individual copyright owners to reproduce any copyrighted material contained within this report. 


\section{Contents}

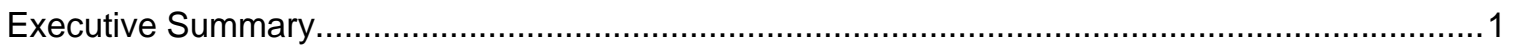

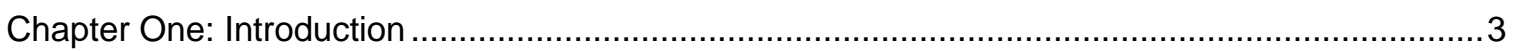

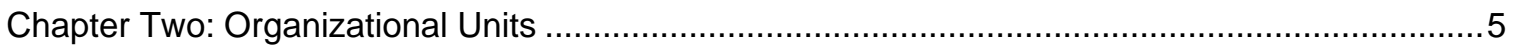

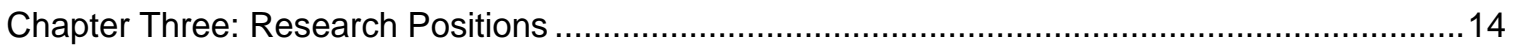

Chapter Four: Survey of Employees in Professional Series Positions within the U.S. Fish and

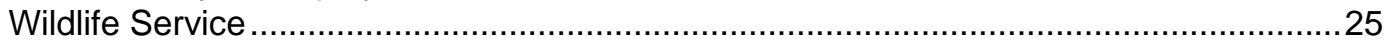

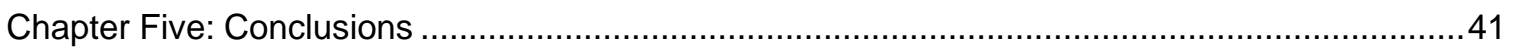

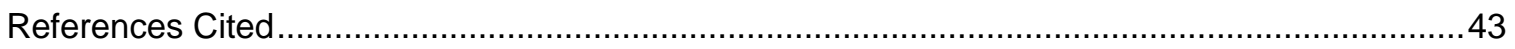

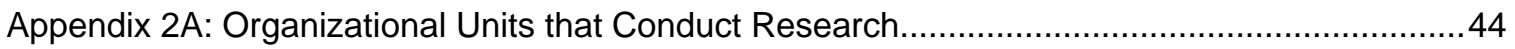

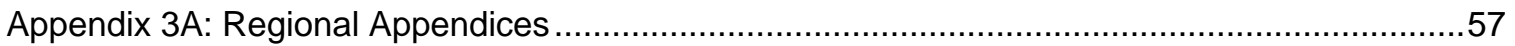

Appendix 3B: Manifest Content Analysis Results ...........................................................118

Appendix 3C: Latent Content Analysis Results................................................................ 122

Appendix 4A: Responses to Open-ended Question Asking All Respondents for

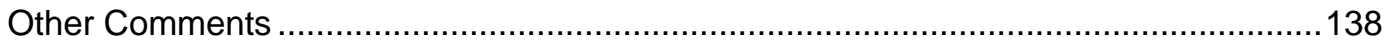

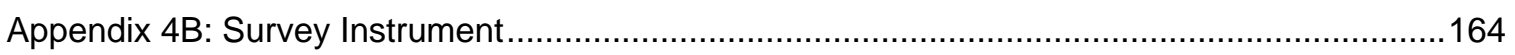

Appendix 4C: Demographic Comparison of Known Publishers versus Other Survey

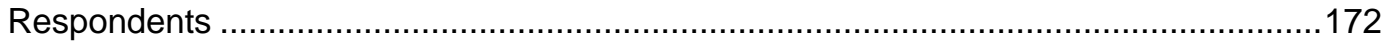




\title{
Quantity, Quality, and Support for Research in the U.S. Fish and Wildlife Service: An Organizational Assessment
}

\author{
By Joan M. Ratz, Phadrea D. Ponds, Jennefer R. Neilson, Joyce Liverca, and Berton Lee Lamb
}

\section{Executive Summary}

To develop a clearer picture of the nature, extent and quality of management support available for conducting research within the FWS, we completed investigations to identify organizational units within the U.S. Fish and Wildlife Service (FWS) that conduct research as a significant portion of their mission; identify positions in the FWS that include, in whole or in part, a component of scientific research; and assess the attitudes of employees and managers about the obstacles and opportunities for scientific research existing within the FWS.

\section{Objectives}

The objective of the organizational units task was to develop a comprehensive list of the units within the FWS that conduct research as either their primary or significant secondary mission. The objective of the research positions task was to identify individual position descriptions that are associated with or include the potential to conduct research. The objective of the attitudinal survey task was to ascertain the attitudes and perceptions of employees involved in research regarding the nature of their research assignment, resources available for research, reporting research results, use of research products, and the obstacles and opportunities for conducting research.

We defined research has having two principal components:

1. Testing formal hypotheses. This type of research is primarily driven by the state-of-the-art scientific literature in a given field. Although the research may be applicable to management issues, the primary purpose of study or investigation is to advance the state of scientific knowledge.

2. Gathering and analyzing data. This type of research is primarily driven by the needs of natural resource managers and/or policy-makers. Although the research may advance the state of scientific knowledge to some degree, the primary purpose is to help managers or decision-makers develop plans or policies or provide input to environmental impact statements, administrative rule-makings, permits, or licenses.

\section{Overview of Findings}

The FWS has a research capacity. That capacity derives from several factors. First, the employees of the FWS have a strong science orientation, which might be termed a science professional culture. The typical FWS employee is trained in the scientific method, enjoys the opportunity to conduct research, and appreciates the research elements of work assignments. Second, based on the respondent's answers to survey questions, the FWS maintains a sizeable data-gathering effort nationwide and especially at its network of fish and wildlife refuges. Third, the FWS includes within the ranks of its employees a range of experts in the natural sciences, especially in fields that apply generally to ecology and habitat and population monitoring. Fourth, a sizeable portion of FWS employees (11\%) have published articles in the scientific literature. 
However, the science capacity of the FWS is neither consistently highlighted in the public documents of the agency nor reflected in the official position descriptions of its employees. Although some FWS regions are more forthcoming about announcing research related activities in web pages and fact sheets, a review of these documents demonstrates that the public face of the agency is not reflective of the research that is underway. Similarly, the utility of position descriptions to highlight research-oriented jobs varies by region and there is little consistency among the regions in how research jobs are described.

From our review of public documents, position descriptions, and the attitudinal survey we have concluded that the research conducted by FWS employees is principally opportunistic. For the most part, research, while recognized as vital and encouraged, is not systematically promoted. Moreover, the most common methods for reporting research findings are through symposia, conferences, or the publications of other state or federal agencies, rather than through the peer reviewed literature.

Even so, FWS employees are basically satisfied with their jobs. Results of the survey show that employees are relatively neutral in assessing the encouragement to conduct or recognition for research they receive from supervisors. Employees expressed lower satisfaction with the management support they receive for research, but did indicate that they have the basic tools-such as computers, vehicles, etc. They are also less satisfied with the financial support or time they receive for research. Employees would strongly favor enhancements to the science reputation of the FWS and those not now involved in research would likely appreciate more research opportunities. 


\section{Chapter 1}

\section{Introduction}

The U.S. Fish and Wildlife Service (FWS) is responsible for managing the Nation's fish and wildlife so that these trust resources are preserved for the present and future use and enjoyment of the citizens of the United States. The FWS achieves this mission by managing many programs. These include the national system of refuges and fish hatcheries, Fish and Wildlife Management Assistance Offices, migratory bird programs, law enforcement, and working with tribal, state, and other Federal agencies to ensure protection of threatened and endangered species. Another role of the FWS is consulting with tribal, state, and other Federal agencies and private sector interests on the best conservation management practices consistent with federal law. Each of these activities requires a workforce that is recognized for its professionalism, dedication to public service, and expert knowledge (Cohn, 2005). Recognition for expert knowledge in fish and wildlife conservation is demonstrated, in part, when FWS personnel direct, conduct, and report research that is focused on questions of importance for natural resource management. The findings reported in this document result from a three-part study of the status of perceived organizational support for research in FWS. The study was commissioned by the FWS Directorate and funded by the FWS, and the Science Support Program and Fort Collins Science Center of the U.S. Geological Survey.

When commissioning this report, the FWS provided an historical and organizational context to serve as a guide. In 1994, the biological research functions of the FWS were transferred to the National Biological Survey, and subsequently into the U.S. Geological Survey. This transfer was accomplished, principally, by moving whole research units from one agency to the other, although some FWS research personnel were probably not transferred. Indeed, some research, information, and management needs of the FWS have continued to be met by studies conducted within the FWS itself despite the loss of much research capability, although the FWS does rely on staff of the U.S. Geological Survey and others for many investigations. The leadership of the FWS expressed the issue that the agency cannot rely solely on others for all of its research needs due to financial and time constraints; therefore, it is vital for FWS employees to be able to conduct such analytical tasks. It is in the best interest of the FWS to promote a culture necessary to support and encourage these activities. Such a culture would reflect organizationwide shared assumptions and values about the importance of research to the mission of the FWS. In commissioning this research, the FWS Directorate recognized that it would be to the advantage of the agency to more fully understand its research capacity.

To develop a clearer picture of the nature, extent, quality, and degree of management support available for conducting research within the FWS, we completed investigations to:

- identify organizational units within the FWS that conduct research as a significant portion of their mission;

- identify positions in the FWS that include scientific research as a component of the position description; and

- assess the attitudes of employees and managers toward the obstacles and opportunities for scientific research existing within the FWS.

In consultation with the FWS, we limited our investigations to individuals in professional series positions. We assumed that the education and skill level necessary for research would be primarily limited to individuals in professional series positions.

\section{Objectives}

To effectively meet the objectives of this study, it is necessary to define "research" rather precisely. For the purposes of this study, research has two principal components:

1. Testing formal hypotheses. This type of research is primarily driven by the state-of-the-art scientific literature in a given field. Although the research may be applicable to management issues, the primary purpose of study or investigation is to advance the state of scientific knowledge. 
2. Gathering and analyzing data. This type of research is primarily driven by the needs of natural resource managers and/or policy-makers. Although the research may advance the state of scientific knowledge to some degree, the primary purpose is to help managers or decision-makers develop plans or policies or provide input to environmental impact statements, management rule-makings, permits, or licenses. objective:

There are three tasks addressed in this organizational assessment study, each with a corresponding

- The organizational units task: to develop a comprehensive list of the units within the Service that conduct research as either their primary or significant secondary mission.

- The research positions task: to identify individual position descriptions that are associated with or includes the potential to conduct research.

- The attitudinal survey task: to ascertain the attitudes and perceptions of employees involved in research regarding the nature of their research assignment, resources available for research, reporting research results, use of research products, and the obstacles and opportunities for conducting research.

\section{Basic Approach}

We did not set out to test any hypotheses. Rather, we intended to provide descriptive information suitable for use by the FWS Directorate in designing improved recordkeeping systems, promoting future research activities, encouraging publication, and providing research guidance.

\section{The Organizational Units Task}

For the organizational units task, we took the following steps: (1) identified organizational units from the official Service directory for each regional office; (2) conducted a review of the unit web page or official documentation to identify unit mission; and (3) interviewed unit leaders to clarify unit mission. The result is a carefully screened listing of units that are potentially involved in research activities.

\section{The Research Positions Task}

For the research positions task we took the following steps: (1) telephoned the chief personnel officer in each Service region to discuss unique regional characteristics that might suggest the best methods available to identify potential positions, and enlisted their support and assistance with subsequent steps in the study; (2) asked personnel offices to query the Department of the Interior standard personnel reporting system to create a roster that included names, titles, series, grades, pay plans, position numbers, organizational codes, birth dates, gender, service computation dates, functional classifications, educational levels, supervisory levels, work schedules, tenures, and servicing personnel offices; and (3) using FWS Region 6 as a prototype, gathered position descriptions from each region to investigate the extent and type of research content in FWS positions descriptions.

We conducted a qualitative analysis of the position descriptions to identify types of research content using NVivo ${ }^{\mathrm{TM}}$, a software package that exports results from a qualitative to a quantitative format (Lamb and others, 2001). We then used the Statistical Package for the Social Sciences (SPSS $\left.{ }^{\mathrm{TM}}\right)$ to analyze the data. The results of this analysis permitted us to identify positions in the FWS with research-related components and specify the type of research content in these positions.

\section{The Attitude and Perception Survey Task}

The survey results answer these questions: What is nature of current research assignments? What resources are available for research studies? How are research results reported? How are research products used by managers? What are the obstacles and opportunities for conducting research? We pre-tested the survey instrument by asking the regional research coordinators and regional chiefs of human resources to complete the questionnaire and then we analyzed the results for internal consistency of measures, time required to complete the instrument, Internet accessibility of the questionnaire, and utility of the results. Before finalizing the survey instrument, we also conducted a pretest with several FWS field biologists. We have produced a Report to Respondents (Neilson and others, 2005), which includes a description of survey methods and the descriptive statistics for each question contained in the survey. 


\section{Chapter 2}

\section{Organizational Units}

The objective for this task was to develop a comprehensive list of the units within the FWS that have, as either their primary or significant secondary mission, the conduct of scientific research. The data represent the results of an organizational unit assessment conducted in the spring of 2004. Occasionally, direct quotes from websites and fact sheets are used to illustrate the findings.

By examining documents that are widely available to the public (e.g., websites and fact sheets), we have tried to illuminate the agency's self-understanding of its capacity to conduct research. Systematically gathering these data allowed us to build a broad overview of the FWS. Our goal was to develop an accurate and up-to-date list of FWS research units. Through this approach we also constructed a database linking published authors to FWS units, and examined specific textual information on FWS web pages and public fact sheets. We used three primary information sources to identify the research oriented organizational units:

1. Web of Science publication database,

2. official FWS websites, and

3. regional fact sheets (including specific organizational units such as refuges or fish hatcheries).

\section{Methods}

Data were collected in two steps. First, we aggregated information from the Web of Science database to identify the published FWS researchers in each of the eight FWS regions. Second, we analyzed text-based media (TBM) to find the names and number of units within the FWS that describe research on either their web pages or in their public fact sheets.

\section{Identification of Researchers}

The first step in our work involved identifying individuals within FWS who are engaged in research activities. We interviewed Regional Research Coordinators to identify individuals in the FWS who were conducting research. We expected to interview those individuals to ask for the names of other individuals likewise involved with research. Because we determined that this task could be accomplished more efficiently through a standardized database search and because we did not want to bias any potential respondents to the upcoming survey, we used the Web of Science to identify individuals affiliated with FWS who had published research-based articles during the time frame of 1995 through July 21, 2004. We crosschecked the resulting list with the names of those individual people who continue to be listed as employed by the FWS. The Web of Science database does not reference all publication outlets relevant for FWS employees, but it does include the broad subjects of natural sciences and water resources. It also includes more specific subjects such as earth resources, and wildlife and fishery/fisheries. Although we recognize that the resulting list of published researchers is most likely not exhaustive, the Web of Science database indexes several thousand journals (including Journal of Wildlife Management, Wildlife Society Bulletin, and North American Journal of Aquaculture) and should provide a rather good representation of those FWS employees who have published. We restricted the documents included in the search to research articles, research notes, and research-based reviews. The initial search resulted in the identification of 1,355 articles.

We looked at each article individually to determine if the author had been an FWS employee during the period 1995-2004, based on the FWS directory and the personnel roster. We used the FWS directory and roster to identify their current FWS organizational affiliations. We physically reviewed the articles if the journal was available at the U.S. Geological Survey library at the Fort Collins Science Center, at the library of Colorado State University, through interlibrary loan, or in online/electronic journals. Upon review of each article, if the author had another affiliation at the time of the study but a footnote indicated that his/her current address was with the FWS, that record was eliminated. For example, someone who published their master's thesis after joining the FWS would show a university affiliation at the time of the study and would not be counted as a published FWS employee. 
The result of this effort was a database of published FWS employees $(n=576)$. We found that 50 individuals were no longer FWS employees and those names were deleted from our list. Of the remaining 526 individuals identified as having published while employed by the FWS, 30 were in nonprofessional series positions. Accounting for these factors resulted in a list of 496 people who had published while in professional series positions while employed by the FWS from 1995-2004 (Table 2.1).

Table 2.1. Number of authors and organizational units identified by review of publications and websites.

\begin{tabular}{|c|c|c|c|c|}
\hline & \multicolumn{2}{|c|}{ \# published authors (between 1995-2004) } & \multirow{2}{*}{$\begin{array}{c}\text { \# organizational } \\
\text { units }\end{array}$} & \multirow[t]{2}{*}{ \# websites analyzed } \\
\hline FWS region & Non-professional series & Professional series & & \\
\hline Region 1 & 2 & 114 & 50 & 27 \\
\hline Region 2 & 6 & 36 & 27 & 16 \\
\hline Region 3 & 1 & 56 & 30 & 25 \\
\hline Region 4 & 5 & 61 & 41 & 17 \\
\hline Region 5 & 9 & 50 & 34 & 4 \\
\hline Region 6 & 2 & 64 & 40 & 23 \\
\hline Region 7 & 1 & 64 & 22 & 8 \\
\hline Region 9 & 4 & 51 & 14 & 1 \\
\hline Total & 30 & 496 & 258 & 121 \\
\hline
\end{tabular}

ancludes all identified authors without distinguishing between professional and non-professional series employees or current employees.

We believe this method yielded a higher volume of names in a shorter amount of time than would the interview-based approach. Additionally, the database search identified researchers in the most objective way possible and provided sufficient information to address the issues associated with each task of this study in a reliable and straightforward manner. This revision to the original study plan was essential and beneficial. Although identification of published researchers in this manner is not an ideal measure of research capability, we believe this technique was a valid means to identify those engaging in research. However, we acknowledge that individuals who are conducting research but are not publishing would not be identified by this approach. We used these names in the organizational units task to identify in which organizational units people were likely to be conducting research, in the research positions task to identify which position descriptions we should analyze, and in the attitudinal survey task to identify target individuals to receive the survey.

\section{Websites and Fact Sheets}

We used the World Wide Web (i.e., Internet) to search for relevant websites and facts sheets. We based our searches on phrases combining "Fish and Wildlife Service, FWS, refuges, research, and monitoring." We searched MSN (16,695,607 hits), Google (232,661,991 hits) and Netscape (1,350,000 hits). Comparing the three web search engines we found that the first 5 "hits" were typically the same in each case:

- U.S. Fish and Wildlife Service Home (www.fws.gov)

- For Kids: U.S. Fish and Wildlife Service Home (www.fws.gov/kids)

- Who We Are (www.fws.gov/who)

- Endangered Species Program, U.S. Fish and Wildlife Service (endangered.fws.gov)

- $\quad$ Southeast Region, U.S. Fish and Wildlife Service (southeast.fws.gov)

To select the FWS websites, we used the database of published individuals within FWS (as described above; Table 2.2). 
Table 2.2. Examples of information on selected Fish and Wildlife Service websites.

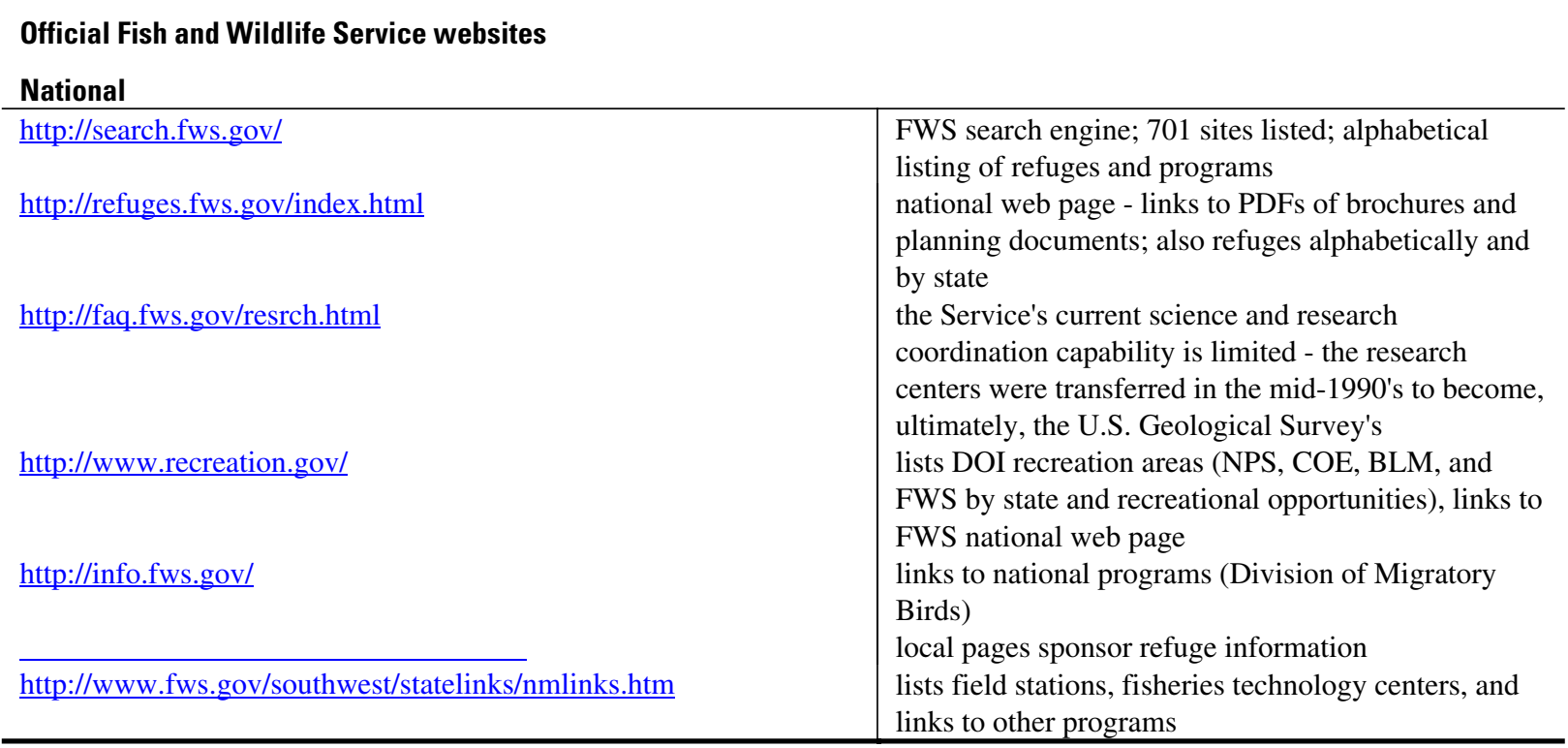

Official Fish and Wildlife websites

\begin{tabular}{|c|c|c|}
\hline \multicolumn{3}{|l|}{ By region } \\
\hline Region 1 & $\begin{array}{l}\text { http://pacific.fws.gov/refuges/ } \\
\underline{\text { http://www.fws.gov/pacific/oregoncoast/ }} \\
\underline{\text { http://www.fws.gov/pacific/pacificislands/ }} \\
\underline{\text { http://sacramento.fws.gov/about us.htm }}\end{array}$ & $\begin{array}{l}\text { easy to search drop down alphabetical list of refuges, } \\
\text { list fisheries and programs separately } \\
\text { Oregon Coast National Wildlife Refuge Complex } \\
\text { home page, featuring the six refuges of the complex }\end{array}$ \\
\hline Region 2 & http://www.fws.gov/southwest/refuges/index.html & $\begin{array}{l}\text { "featured refuge"; links refuges by states; links to } \\
\text { national site }\end{array}$ \\
\hline Region 3 & $\begin{array}{l}\underline{\mathrm{http}: / / \text { www.fws.gov/midwest/ }} \\
\underline{\mathrm{http}: / / \text { www.fws.gov/midwest/fisheries/ }} \\
\underline{\mathrm{http} / / / \text { www.fws.gov/midwest/InsideRegion3/ }}\end{array}$ & $\begin{array}{l}\text { links to offices and services in Region } 3 \text {; } \\
\text { "will work with the USGS to identify research } \\
\text { priorities" } \\
\text { inside Region } 3 \text { - information update of regional } \\
\text { activities; articles about monitoring and cooperative } \\
\text { research efforts and planning }\end{array}$ \\
\hline Region 4 & $\begin{array}{l}\text { http://www.fws.gov/southeast/refuges/ } \\
\underline{\text { http://www.fws.gov/southeastlouisiana/ }}\end{array}$ & $\begin{array}{l}\text { links to a regional page with links to refuges } \\
\text { alphabetically by state, Regional office news, etc. } \\
\text { most consistent website and content. } \\
\text { does not link back to Region } 4 \text { homepages; links to } \\
\text { regional, state and local pages; FWS national page; } \\
\text { and a map to SE LA refuges }\end{array}$ \\
\hline Region 5 & $\begin{array}{l}\text { http://northeast.fws.gov/ } \\
\text { http://www.fws.gov/patuxent/prrdefault.html } \\
\text { http://northeast.fws.gov/facts.html }\end{array}$ & $\begin{array}{l}\text { "reports from the field" } \\
\text { this page contains more than } 100 \text { fact sheets from } \\
\text { refuges, field offices, Fish Hatcheries, and } \\
\text { management districts }\end{array}$ \\
\hline Region 6 & $\begin{array}{l}\underline{\mathrm{http}: / / \text { mountain-prairie.fws.gov/ }} \\
\underline{\mathrm{http}: / / \text { mountain-prairie.fws.gov/preble/ }}\end{array}$ & $\begin{array}{l}\text { since } 1995, \text { much has been learned about PMJM due } \\
\text { to research conducted by the Colorado Division of } \\
\text { Wildlife, Wyoming Game and Fish Department, U.S. } \\
\text { Air Force, U.S. Department of Energy, U.S. Fish and } \\
\text { Wildlife Service, }\end{array}$ \\
\hline Region 7 & http://alaska.fws.gov/index.htm & $\begin{array}{l}\text { links to R7 Refuges, partnerships, science projects, } \\
\text { news and photos }\end{array}$ \\
\hline
\end{tabular}


We used a modified content analysis technique (Busch and others, 2005) to evaluate available FWS webbased and print media. We used the list of published researchers to search the Internet to find the Regional websites (Refuges, Fish Hatcheries, Field Offices, and affiliated science centers) and used an a priori coding method to establish key word categories (research, investigations, studies, projects, and monitoring) to perform our initial analysis of the websites and fact sheets (Weber, 1990). This consisted of identifying the existence of certain words and phrases used to communicate research. Afterwards, we examined the relationships of the words in the text to determine how the words or phrase were used to describe research (Busch and others, 2005). The following rules were used to select websites or fact sheets:

- $\quad$ all links had to include fws.gov;

- links to second level websites were included only if they were an "official" FWS website (e.g., a refuge, project, or supporting program website);

- graphics attached to the website depicting a monitoring activity (e.g., banding, electro-shocking, or specimen collecting) were not included;

- the link was included only if it described research that was physically and currently being conducted by FWS researchers;

- if the work was co-sponsored by FWS as an agency, the site was coded as "FWS sponsored research",

- we omitted Law Enforcement and FWS Administrative offices; and

- although often interesting, links to third-level websites were not included.

Once these data were collected, we identified common themes and organized the data into six distinct subcategories. To understand how the descriptors were used, we selected Refuges and Hatcheries because we believed they were more likely to conduct studies to meet specific management needs. The following categories represent recurring topics found on Refuge and Hatchery websites, and in fact sheets used to describe the application of research as:

1. specific management tools

2. applied or basic techniques

3. specific Refuge objectives

4. supported by other federal and state agencies

5. "promoted" or "encouraged"

6. a "major activity"

We created separate data sets and tabulations for each FWS region. Creating these tabulations was a rather complicated task because the currency and availability of fact sheets varied across regions. Region 3 made their complete fact sheets available online (for 2003). Regions 4, 5, and 6 informed us that individual fact sheets were available online. We were able to obtain fact sheets for Regions 1,2, and 7. We were able to obtain hard copies of fact sheets for all states, with the exception of California and Nevada, and for all regions except Region 9. We reviewed the hard copies of available fact sheets for indications that research was being conducted. Although fact sheets were usually available online and were usually linked to a unit's homepage, we discovered that these documents tended to represent general descriptions of the unit's goals and highlights of activities rather than descriptions of research.

\section{Findings}

\section{Individual Researchers}

Identifying individual known researchers was a critical first step for the successful completion of this study. For all FWS professional series employees, 1 out of $9(11 \%)$ had published (Table 2.3). Of the geographic regions, Region 1 had the most individual researchers ( $n=114 ; 23 \%$ of 496 who had published) and Region 2 had the fewest $(n=36 ; 7 \%)$. Region 7 had the highest ratio of researchers to professional series employees $(n=64 ; 20 \%)$. Other than for Region 7, the ratio of researchers to number of professional series employees per region was roughly proportional. Fourteen percent $(n=51)$ of employees in Region 9, the FWS Headquarters, had published. The proportion of published researchers in Region 3 (12\%) was slightly higher than either Regions 5 or $6(11 \%)$, and markedly higher than Regions 2 and 4 (9\%). 
Table 2.3. Percentages for publishers versus non-publishers in Fish and Wildlife Service, professional series positions (citations from 1995-2004, Web of Science database).

\begin{tabular}{l|l}
\hline Of the 4435 individuals in the FWS & $496(11 \%)$ of them have published \\
Of the 1142 individuals in Region 1 of the FWS & $114(10 \%)$ of them have published \\
Of the 420 individuals in Region 2 of the FWS & $36(9 \%)$ of them have published \\
Of the 465 individuals in Region 3 of the FWS & $56(12 \%)$ of them have published \\
Of the 706 individuals in Region 4 of the FWS & $61(9 \%)$ of them have published \\
Of the 449 individuals in Region 5 of the FWS & $50(11 \%)$ of them have published \\
Of the 561 individuals in Region 6 of the FWS & $64(11 \%)$ of them have published \\
Of the 321 individuals in Region 7 of the FWS & $64(20 \%)$ of them have published \\
Of the 371 individuals in Region 9 of the FWS & $51(14 \%)$ of them have published \\
\hline
\end{tabular}

Note: Percentages are rounded to the nearest whole number and therefore may not sum to 100.

Of the 496 individuals in the Fish and Wildlife Service who have published:

$114(23 \%)$ of them are located in Region 1
$36(7 \%)$ of them are located in Region 2
$56(11 \%)$ of them are located in Region 3
$61(12 \%)$ of them are located in Region 4
$50(10 \%)$ of them are located in Region 5
$64(13 \%)$ of them are located in Region 6
$64(13 \%)$ of them are located in Region 7
$51(10 \%)$ of them are located in Region 9

Note: Percentages are rounded to the nearest whole number and therefore may not sum to 100.

We used the four FWS programs to categorize each organizational unit into the following groupings:

1. National Wildlife Refuges and Complexes

2. FRO, FWMAO National Fish Hatcheries, Health Science Centers, Fish Technology Centers

3. Ecological Services

4. Migratory Bird

5. Region 9 (headquarters)

The Wildlife Refuges were responsible for $35 \%(n=173)$ of the research publications authored by FWS employees. Fish Resource Office (FRO) and Fish and Wildlife Management Assistance Office (FWMAO) were coded into a single variable that also included fish hatcheries and Health Science Centers collectively representing $25 \%(n=132)$ of the published researchers. Ecological Services $(n=126)$, including regional and field offices, accounted for another quarter $(25 \%)$ of known researchers. Less than $1 \%$ of the published researchers were found in Region 9 (Table 2.4).

Table 2.4. Number of published authors by organizational unit, including non-professional series personnel.

\begin{tabular}{l|c}
\hline Organizational unit variables & Number of published authors \\
\hline National Wildlife Refuges and Complexes & 173 \\
FRO, FWMAO, National Fisheries Hatcheries, Health Science Centers & 132 \\
and Fisheries Tech Centers & 126 \\
Ecological Services & 55 \\
Migratory Birds & 8 \\
Region 9 & 494 \\
Total & 8 \\
\hline
\end{tabular}




\section{Public Fact Sheets and Websites}

We reviewed all the available websites and fact sheets that indicated research was being conducted in an organizational unit (Appendix 2A). The degree to which research was identified in fact sheets varied a great deal from region to region and among organizational units. A total of 399 descriptors were collected using an a priori coding method. We found that the words "research," "investigations," "studies," "projects," and "monitoring" were often included under a heading of "Management Tools" or "Refuge Objectives" without any elaboration of the research being conducted (Table 2.5).

We found that these descriptors were used in different regions and in many combinations. Some examples of how the descriptors were used on websites and fact sheets to communicate research efforts include:

1. specific management tools - Clarks River NWR, Cross Creek NWR

2. applied or basic techniques - Hakalau Forest NWR, Cape Romain NWR

3. $\quad$ specific Refuge objectives - \#6 at Agassiz NWR, and \#7 at Turnbull NWR

4. supported by other federal and state agencies - Mississippi Sandhill Crane NWR

5. "promoted" or "encouraged" - Bayou Teche, NWR and Cameron Prairie NWR, Lee Metcalf NWR, Sacramento National Wildlife Refuge Complex

6. a "major activity" Florida Panther NWR and Sevilleta NWR

Organizational unit fact sheets included a range of specificity in descriptions of research. For example, the fact sheet for the Green Lake National Fish Hatchery in Maine included as a management activity to "Assist with ongoing Atlantic salmon research" but did not describe how the hatchery assisted or provided any specific information about the research. Other fact sheets are more specific; the fact sheet for the Willow Beach National Fish Hatchery in Arizona stated that the unit, "Successfully examined the effects of temperature on growth of razorback suckers, bonytail chub and humpback chub for captive propagation recovery."

\section{Regional Scenarios}

Of particular interest is Region 7's website. The Alaska region stands out as having the most organized and consistent mode of communicating research activities. Study plans for research projects that are either being conducted by FWS employees or in cooperation with other agencies are listed on each web page. The Alaska "science" web page was very specific:

Science is the foundation for the work of the Service. In our commitment to quality science we strive to ask the right questions, base our work on accepted scientific principles, seek independent peer review and publish our results (http://alaska.fws.gov/science/index.htm - retrieved 4/12/05).

The websites for Region 7 all included a link to "biological studies," biological projects" or "science." These pages consistently included links to management plans, publications, projects in progress, and graphs of population trends. Typical statements include:

Science is the backbone of the Fish and Wildlife Service. Quality scientific projects are the underpinning of good management and decision-making. Fish and Wildlife Service employees in the various programs and field offices in Alaska are engaged in a wide variety of scientific projects to meet our stewardship and conservation missions. (http://alaska.fws.gov/science/project.htm - retrieved 3/19/05)

The Refuge also sponsors and conducts basic and applied research projects, develops monitoring methods, and evaluates management strategies (http://alaska.fws.gov/nwr/kodiak/biowork.htm retrieved 3/19/05)

Websites and fact sheets for Region 4 consistently identified research as a "management tool." Unlike Region 7, there were no links to specific study plans or attribution of research projects to a specific FWS employee. The Region 4 documents tended to be very generic in describing projects with language such as the following:

Scientific research, investigations and monitoring projects on the refuge help us to answer the "what" and "why" questions about the Everglades-both the wildlife and their habitats. Projects such as alligator surveys help us understand how many alligators there are, how productive they are and how they relate to the world around them. Studies on tree islands help us to learn their 
importance to wildlife and how changes in water management may affect them. (http://loxahatchee.fws.gov/home/default.asp - retrieved 3/30/05).

Deer management includes medical and rehabilitation, habitat restoration and enhancement, routine herd health monitoring and population checks, and research on population density, behavior and migration patterns. (http://nationalkeydeer.fws.gov - retrieved 3/30/05)

The public documents for Region 4 and 6 link monitoring, research and management. For example, Loxahatchee NWR web page states:

Monitoring can be a part of research which is a systematic investigation into a subject in order to discover facts or principles.

Current research projects being conducted by refuge biologists include examining the impacts of hydrology on tree island vegetation and wildlife; answering the question: "Do melaleuca and lygodium influence the vegetation, insect, and bird communities on tree islands?", and "How does the body condition of alligators in the refuge relate to the body condition of alligators in other areas?" (http://loxahatchee.fws.gov/biology/research.asp)

A web page from Region 6 reports:

Monitoring/Research is being done at Long Lake National Wildlife Refuge (NWR) on all the following subjects with our limited staff and the help of volunteers.

This research includes total avian species richness, endangered/threatened species, including the piping plover, spring and fall waterfowl migration, duck production estimates with research on nest searches, nest success, nest predation and artificial nest structures, marsh/water birds, raptors, and other migratory bird observations are noted as part of this research.

(http://longlake.fws.gov/research.htm)

The website for Patuxent Research Refuge in Region 5 reports that it is the "Nation's only National Wildlife Refuge established to support wildlife research," however acknowledges the U. S. Geological Survey's research function: "Today most of the research on the refuge is conducted by the U.S. Geological Survey (USGS) through the Patuxent Wildlife Research Center."

Overall, in Regions 2, 3, and 5 the information regarding research in FWS was inconsistently presented in fact sheets and websites. However, there tended to be more consistency within these Regions in specifying site location, management objectives and available activities. 
Table 2.5. Examples of research and related terminology found on a sample of web pages.

\begin{tabular}{|c|c|}
\hline Investigations & $\begin{array}{l}\text { Our Bio-Monitoring Branch conducts field studies to determine sources of pollution, to } \\
\text { investigate pollution effects on fish and wildlife and their habitat and to investigate fish and } \\
\text { wildlife die-offs. (Sacramento FWS Office website) }\end{array}$ \\
\hline Monitoring & $\begin{array}{l}\text { Monitoring/Research is being done at Long Lake National Wildlife Refuge (NWR) on all the } \\
\text { following subjects with our limited staff and the help of volunteers. } \\
\text { (http://longlake.fws.gov/research.htm) }\end{array}$ \\
\hline Science & $\begin{array}{l}\text { Science is an integral part of the Fish and Wildlife Service. We employ many biologists, who } \\
\text { through our various field and laboratory programs, generate scientific information that supports } \\
\text { our conservation mission. The scientific activities we conduct are diverse, ranging from basic } \\
\text { inventories of fish and wildlife species on remote National Wildlife Refuge lands, to population } \\
\text { monitoring of select wildlife species, to applied research to help us make management decisions. } \\
\text { The ever-escalating complexity of natural resource conservation in Alaska demands that the } \\
\text { scientific information we collect and use is rigorous, timely and relevant. } \\
\text { (http://alaska.fws.gov/science/overview.htm) }\end{array}$ \\
\hline Research & $\begin{array}{l}\text { AFWO's diverse workload responsibility includes field research and monitoring, regulatory and } \\
\text { advisory roles in various federal agencies, habitat conservation planning on nonfederal lands, } \\
\text { permit review, and many other biological related activities. (http://www.ccfwo.rl.fws.gov/) } \\
\text { As a management tool (http://www.fws.gov/crosscreeks/) } \\
\text { “...the Patuxent Research Refuge is the nation's first and only National Wildlife Refuge devoted } \\
\text { to wildlife research.” (http://www.fws.gov/patuxent/prrdefault.html) } \\
\text { The refuge is engaged in research that is unlocking the natural history secrets of American and } \\
\text { least bitterns, moose and timber wolves (http://www.fws.gov/midwest/agassiz/) } \\
\text { The priorities of the Program are as follows...\#4 Coordinate and conduct research activities } \\
\text { (http://www.fws.gov/contaminants/issues/invasivespecies.cfm). } \\
\text { The Fish and Wildlife Service oversees the research program, working jointly with several } \\
\text { cooperating organizations and agencies. (http://midway.fws.gov/wildlife/research.html) } \\
\text { Refuge wildlife biologists conduct scientific research to understand how to better manage the } \\
\text { refuge for wildlife. (http://moosehorn.fws.gov/wildlife research.htm) }\end{array}$ \\
\hline Project & $\begin{array}{l}\text { 1) "For every scientific project that we conduct in the field, Service biologists are required to } \\
\text { analyze their data and write a report. In order to complete the scientific process, these reports are } \\
\text { reviewed, revised and then disseminated to managers, other researchers and the public. For } \\
\text { projects that pioneer new techniques, provide findings new to science, or are of high interest to } \\
\text { the scientific community, these reports may form the basis for manuscripts that are later submitted } \\
\text { to peer-reviewed scientific journals or are presented at scientific meetings." } \\
\text { (http://alaska.fws.gov/science/report.htm) } \\
\text { 2) A scientific study is complete when the manuscript summarizing the results of the work has } \\
\text { undergone peer review, been revised and disseminated to the scientific community. } \\
\text { (http://alaska.fws.gov/science/publication.htm) } \\
\text { This project is being conducted by researchers from Medicine Lake NWR, St. Cloud University, } \\
\text { and Earthspan... } \\
\text { (http://medicinelake.fws.gov/Wildlife/PelicanBrief.pdf) }\end{array}$ \\
\hline
\end{tabular}

\section{Discussion}

The purpose of the organizational unit assessment was to use at least three media sources to identify FWS units reporting research as either a primary or a secondary role or objective. We chose the three sources for this task (publications, websites, and fact sheets) because they were the most conspicuous and up-to-date references used to describe current FWS activities. Our findings suggest that the public documents of the FWS often point toward the existence of noteworthy site-specific research. This is indicated by the descriptive language and terminology we found on the web pages and fact sheets. However, the various FWS Regions use at least six distinct categories of language to describe the nature of research activities in which their organizational units are engaged. There is little consistency among the public documents and they do not appear to conform to any standard for research. 
We were able to identify 275 units that conduct research, and 496 individuals in professional series positions as having published since 1995. Science continues to be "the foundation for the work of the Service." Regions 7, 1, and 4 were the most consistent in reflecting this philosophy on their public documents. Their websites and fact sheets generally underscore their commitment to science by offering "science" or "project" pages.

It seemed that most of this work is aimed at using data to meet a specific management objective or goal. The public documents for Loxahatchee NWR are typical in suggesting that FWS managers believe research and monitoring provides a necessary foundation for successfully managing the unit.

Regions 9, 5, 3 and 6 were the most consistent in stating that the research functions of the FWS are now part of the U.S. Geological Survey. Their websites and fact sheets generally provide a link to the U.S. Geological Survey Biological Resources Division's website or, in the case of Patuxent Research Refuge, to the Patuxent Wildlife Research Center's website. Because the public documents do not consistently underscore the science commitment of the FWS, it is difficult to develop a sense from the public documents that science is an important part of the agency's management philosophy.

Our analysis of all the documents suggests that individual organizational units view themselves as conducting research to meet management obligations. Not all organizational unit web pages and fact sheets succeed in describing the research conducted, but taken together it is clear that the management needs of the FWS are being met by studies conducted within the FWS itself. Although it is apparent that for larger scale research the FWS relies on the U.S. Geological Survey and others for many investigations, the web pages and fact sheets are neither consistent across the regions nor between regions and headquarters. The overall impression is that the FWS conducts studies to meet management needs and larger scale scientific research is the business of someone else. 


\section{Chapter 3}

\section{Research Positions}

The objective for this task was to identify positions that are creating knowledge or conducting research, and to determine whether or not these position descriptions reflect a research capacity in the FWS. To that end, we used a query of the Federal Personnel/Payroll System (FPPS), interviews with Regional Personnel Officers, and analyses of position descriptions of select FWS employees to determine which positions had research-related content and what type of research content was present in these positions. The primary research strategy in addressing this objective was a content analysis of FWS position descriptions. The FPPS query and interviews were preliminary steps, which contributed to the content analysis.

\section{Methods}

\section{FPPS Query}

Personnel in the FWS Department of Human Resources queried the FPPS for us. The query provided us with a database of information for all individuals in the FWS who are in professional series positions (i.e., we excluded personnel in administrative, technical, clerical, and trade/labor positions). The database included name, title, series, grade, pay plan, position number, organizational code, birth date, gender, service computation date, functional classification, educational level, supervisory level, work schedule, tenure, and servicing personnel office. We did not analyze this personnel data extensively; rather, we used the data to facilitate the other aspects of this task. We derived questions for our interviews with the personnel officers from the personnel data. We used the personnel data in selecting a sample of position descriptions for the content analysis.

\section{Interviews with Regional Personnel Officers}

We generated a list of questions for our interviews with the Regional Personnel Officers (RPOs) including questions about characterizing the work of the region, classification of positions, and research within the region. We first interviewed the RPO for Region 6, and used his responses to edit our initial questions (Table 3.1).

We contacted the RPOs to arrange telephone interviews with them or delegates of their choice. Most RPOs opted to take part in the interview personally rather than delegate the responsibility, and some chose to include one or more classification specialists in the conversation. The responses to the interview questions that are most pertinent to the objective of this study are summarized here.

Consistently, the RPOs expressed the view that their region had characteristics (such as geography, habitats, or species) that set them apart from other regions. They frequently cited either the types or numbers of endangered species present as being a contributing factor to the uniqueness of their region. Other factors cited in response to this question include climate differences and interactions with outside entities such as Tribal nations or other countries. They suggested that these differences may affect research productivity and that some species and habitats may be more conducive to study or generate more research interest than others.

We were particularly interested in functional classification 11, which denotes the primary work content of a position as research and we used the FPPS database to identify individuals in each region with this functional classification. In our interviews with the Regional Personnel Officers, we asked them specifically about positions in their regions with a functional classification of 11 ( 6 of the 8 regions had personnel with this classification). Many of them expressed surprise to learn that any positions in their region were classified as 11 . We pressed the RPOs to verify the accuracy of these classifications, and in every region they judged the majority of these classifications to be inaccurate. We asked about the use of the Research Grade Evaluation Guide (RGEG) in personnel actions, and all of the RPOs indicated that they rarely used it. [As a side note, within the sample of position descriptions we analyzed 
Table 3.1. Interview questions asked of regional personnel officers.

General questions

1. Describe your region from a personnel perspective. How is the work done in Region X different from the work done in other regions? (e.g. some regions have more WMDs than others or different types of species that induce more research interest.)What is unique about this region in terms of personnel?

2. Any trends occurring in the professional series positions? (e.g., more or fewer professionals; grades increasing/ decreasing; series shifts?)

3. Is there a goal supervisory ratio in your region? Is the goal realized in the region?

4. We see about X code 4 supervisors in the professional series roster [Code 2 (official supervisor) and Code 4 (performs some supervisor functions, such as a team leader, but not the full range required to be officially titled a supervisor)] What are the circumstances under which you are using Code 4 ?

5. I see X titles in Region X using "lead" in the job title designating team lead's in the professional series roster. What is the situation with regard to the use of team leads in this region? Throughout the Fish and Wildlife Service?

6. What's the region's biggest challenge in terms of professional series classification?

7. How accurate do you think the educational level coding is in FPPS (Federal Personnel and Payroll System)?

\section{Research questions}

1. There are $\mathrm{X}$ employees in the roster who are assigned a functional research code (11). Do they go through peer review panels for promotions or does classification just use the RGE (Research Grade Evaluation) Guide to determine grade level?

2. Aside from those employees with a functional code of research (11), to your knowledge, are there any other employees doing research in your region? Any ideas on how they might be identified through the Personnel system?

3. What is the Fish and Wildlife Service policy (or Region X policy) on describing research activities in PDs?

4. How standardized are professional series PDs?

5. Are there any key words we should look for in PDs that might be suggestive of someone involved in research activities?

6. Are there particular entities (org codes) doing more research than others?

7. How accurate do you think the PDs are?

8. Do you think the other regions are similarly situated in regards to the extent of research going on, the ability to determine who is involved in research work, how the PDs are written, etc.?

\section{Request for position descriptions}

Part of this study involves an analysis of position descriptions between those of employees known to be doing research and a matched set of those where we do not know if they are doing research or not. For this purpose we need to obtain about XX position descriptions.

(discussed below), only one indicated that the RGEG had been used in classification. That position description was for a geneticist in Region 2.] While we were discussing classification issues with the RPOs, we asked them if they knew of any policy in the FWS or within their region regarding describing research activities in position descriptions. They unanimously agreed that there was no policy regarding this issue. Two of the RPOs added the comment to their response that research was not part of the mission of FWS, and that as a consequence no such policy would be necessary.

We asked the RPOs to identify other employees or organizational units doing research in their region. Their responses to these inquiries most commonly suggested that research is more likely to be done by individuals in fisheries, fish health, or technology centers. Two interview questions asked about identifying employees doing research through the personnel system or position descriptions. The RPOs were skeptical that researchers could be identified through either of those methods. Several keywords were suggested by the RPOs, which we used later as part of our content analysis of position descriptions.

Although the RPOs were in agreement on many of the questions we asked, they gave a broader range of answers to our questions regarding standardization and accuracy of position descriptions. The responses to the question about standardization ranged from there being so much standardization as to create the potential for overuse to there being little to no standardization of position descriptions. Their opinions about the accuracy of position descriptions ranged from very accurate to not at all accurate. 


\section{Analysis of Position Descriptions}

The primary aim for the research position component of the overall study was to identify positions that are creating knowledge or conducting research. Evaluation of required knowledge, skills, and abilities that relate to research provides information relevant to assessing the capacity within FWS for conducting research. The analysis of position descriptions gained in importance once we realized that the other personnel data obtained in the FPPS query, which we initially anticipated would be most useful, would not provide much of the information needed for analysis.

\section{Description of Content Analysis}

We opted to use the method commonly known as content analysis because of its systematic approach and applicability to textual information (Riffe and others, 1998). Content analysis can be used to evaluate content at two distinct levels: manifest and latent. The manifest content of a document is the surface level content and is commonly measured with counts of predetermined keywords. Latent content refers to the content meaning derived from text by an individual. In this case, we developed a predetermined set of research related content categories and determined whether or not there was content from each category represented in each position description. We conducted analyses of both manifest and latent content on a sample of FWS position descriptions.

Three caveats are important to note at this point, First, it must be emphasized that the focus of this analysis was the position descriptions, not the positions. Our analysis is directly applicable to the work of employees of the FWS only insofar as the position descriptions are representative of the actual work done by these employees. Our interviews of the RPOs indicate that we may need to interpret these results with some reservation because of questions about accuracy of position descriptions in describing the work done. This concern was reinforced by the fact that only $62 \%$ of survey respondents believed their position descriptions were accurate (see Neilson and others, 2005).

Second, subjective judgment is an inherent part of content analysis. We took the necessary measures to ensure that coding was as reliable as possible. The background of all three coders who coded the latent content of the position descriptions is in Industrial/Organizational Psychology. Although these coders are well versed with research methodology, they are unfamiliar with the particular sciences relevant to FWS. We found that some of the wording in the position descriptions was too vague to indicate research clearly and applied the interpretation of the categories as strictly as possible. As a result, there may be more research content in the position descriptions than we actually coded. What was unclear to us may have been crystal clear to coders with backgrounds in Wildlife or Fishery Biology who, had they been given the opportunity, may have coded the content differently.

Third, we initially intended to conduct analyses of the manifest and latent content of the entire set of position descriptions we sampled (the sampling procedure is described below). We did conduct analysis of the manifest content for the entire sample; however, due to the labor-intensive nature of the coding of the latent content, we could only code a subset of our original sample (Table 3.2). The smaller sample was not problematic overall, but did create some difficulties in interpreting within region analyses.

\section{Selection and Sampling of Position Descriptions}

We used the list of known published researchers generated from a search of the Web of Science database (Chapter 2) as the basis for selecting position descriptions. We requested position descriptions for all of the known published researchers. Additionally, we used the FPPS report to identify a matching set of individuals who were not on the list of known publishers. We treated the list of published researchers as a known group; we knew they were doing research. The matched sample may have been doing research, but they were not publishing (as far as we knew) and we consequently used that group as a proxy for non-researchers because there was no way for us to definitively identify non-researchers. We selected our matched sample to be as similar as possible to the published individuals in occupational classification, grade level, educational level and location. We included location as a matching variable based on our interviews with the RPOs. We did not match on Functional Classification because the interviews with personnel officers indicated that most of the classifications of 11 (Research) were unreliable. We used a matched sample because that strategy allowed us to identify characteristics in position descriptions that distinguish between individuals publishing research and those not publishing, while controlling for potential effects of occupational classification, grade level, and educational level. 
Table 3.2. Sample sizes for content analyses.

\begin{tabular}{|c|c|c|c|}
\hline & $\begin{array}{l}\text { Number of employees in } \\
\text { FPPS report }\end{array}$ & $\begin{array}{c}\text { Number of position } \\
\text { descriptions sampled } \\
\text { (manifest analysis) }\end{array}$ & $\begin{array}{c}\text { Number of position } \\
\text { descriptions coded for } \\
\text { content (latent analysis) }\end{array}$ \\
\hline $\begin{array}{r}\text { All FWS } \\
\text { (less Region 4) }\end{array}$ & 3729 & $\begin{array}{c}761 \\
(20 \% \text { of FWS })\end{array}$ & $\begin{array}{c}247 \\
(7 \% \text { of FWS }) \\
(32 \% \text { of FWS sample) }\end{array}$ \\
\hline Region 1 & 1142 & $\begin{array}{c}217 \\
(19 \% \text { of Region } 1)\end{array}$ & $\begin{array}{c}43 \\
(4 \% \text { of Region } 1) \\
(20 \% \text { of R1 sample) }\end{array}$ \\
\hline Region 2 & 420 & $\begin{array}{c}68 \\
\text { (16\% of Region 2) }\end{array}$ & $\begin{array}{c}31 \\
(7 \% \text { of Region } 2) \\
\text { (46\% of R2 sample) }\end{array}$ \\
\hline Region 3 & 465 & $\begin{array}{c}61 \\
\text { (13\% of Region 3) }\end{array}$ & $\begin{array}{c}29 \\
(6 \% \text { of Region 3) } \\
(48 \% \text { of R3 sample) }\end{array}$ \\
\hline Region 5 & 449 & $\begin{array}{c}95 \\
(21 \% \text { of Region } 5)\end{array}$ & $\begin{array}{c}32 \\
(7 \% \text { of Region 5) } \\
\text { (34\% of R5 sample) }\end{array}$ \\
\hline Region 6 & 561 & $\begin{array}{c}122 \\
(22 \% \text { of Region } 6)\end{array}$ & $\begin{array}{c}38 \\
(7 \% \text { of Region } 6) \\
(31 \% \text { of R6 sample) }\end{array}$ \\
\hline Region 7 & 321 & $\begin{array}{c}105 \\
\text { (33\% of Region 7) }\end{array}$ & $\begin{array}{c}36 \\
(11 \% \text { of Region } 7) \\
(34 \% \text { of R7 sample) }\end{array}$ \\
\hline Region 9 & 371 & $\begin{array}{c}93 \\
\text { (25\% of Region 9) }\end{array}$ & $\begin{array}{c}35 \\
(9 \% \text { of Region 9) } \\
\text { (38\% of R9 sample) }\end{array}$ \\
\hline
\end{tabular}

At the end of our phone interviews with the RPOs, we explained to them why we needed the position descriptions and requested that they provide us with the position descriptions for the individuals on the list that we had sent them about a week after their phone interviews. All of the regions complied with our request. However, because of ongoing changes in the personnel in the Region 4 Personnel Office, we did not receive the Region 4 position descriptions in time for them to be included in our analyses.

When we received the position descriptions, we examined them to remove any duplicates. Although we may have missed some duplicates, we did attempt to identify and eliminate them so that we analyzed a unique set of position descriptions. We used a scanner to create electronic versions of the position descriptions and then proofread the electronic versions for accuracy.

The sample of position descriptions we coded contained the following occupational classifications: 170 (History); 193 (Archaeology); 301 (Miscellaneous Administration and Program); 401 (General Biological Science); 408 (Ecology); 430 (Botany); 454 (Rangeland Management); 480 (Fish and Wildlife Administration); 482 (Fishery Biology); 485 (Wildlife Refuge Management); 486 (Wildlife Biology); 701 (Veterinary Medical Science); 1,320 (Chemistry); and 1530 (Statistician). The majority of position descriptions were from 401, 482 and 486 classifications.

\section{Manifest Content Analysis Procedure}

We identified keywords to use in the manifest content analysis based on the terms suggested by the RPOs, by reviewing the position descriptions of a small sample of known published FWS employees from Region 6 and handful of the research position descriptions in the U. S. Geological Survey. We looked for any words that might be indicative of research. We initially identified over 100 potential keywords. We used the small sample of Region 6 position descriptions to evaluate all the potential keywords and selected those that appeared in a minimum of $75 \%$ of the sampled position descriptions. The 10 keywords used in the manifest analysis are the following: analysis, evaluating, evaluation, methods, monitoring, national (not in a proper name such as the name of legislation or of a refuge), problems, research, scientific, and studies. 
We used the content analysis software NVivo ${ }^{\mathrm{TM}}$ to conduct a word count within each position description for each of the 10 keywords. We analyzed these data, specifically comparing the results of the word counts for the position descriptions of published individuals to the counts for the descriptions of non-published individuals, to determine if any of these keywords were characteristic of research position descriptions.

\section{Latent Content Analysis Procedure}

We developed a set of content categories derived in part from the research checklist used in the attitudinal survey component of this study (Chapter 4). We augmented this list with other categories we believed to be relevant to research, and added a list of research-related knowledge, skill, and ability requirements. Several members of our team reviewed and edited the initial list of categories. This internal review panel included an individual with expertise in position descriptions and two individuals who had previously worked in the FWS and were, therefore, uniquely qualified to assess the content of the coding categories. Our list includes seven primary categories of content, which break down into 27 total sub-categories. The seven primary categories are research, planning, execution, analysis, dissemination, application, collaboration, and research-related knowledge, skill, and ability requirements. The complete list of the categories, sub-categories and their definitions is provided in Table 3.3.

Because of the subjective nature of the judgments involved in conducting a latent content analysis, we incorporated a reliability check into our methods. We planned to have all of the position descriptions in the original sample coded by the primary coder with a sub-sample of the position descriptions coded by a secondary coder. We could then compare the coding values of the primary and secondary coder to determine how reliably the primary coder applied the content categories to the content of the position descriptions. Due to practical considerations, we were unable to code the entire sample of position descriptions. We coded the reliability sample for each region instead. So in this case, instead of only a sub-sample of the position descriptions being coded by a secondary coder, all of the position descriptions coded by the primary coder were coded by a secondary coder as well.

We determined the size of the reliability sample using a formula provided in Riffe, Lacy and Fico (1998). We used the random selection function of $S P S S^{\mathrm{TM}}$ to select a sub-sample of position descriptions from within each region. We used regional level data to calculate the reliability sample (Table 3.2).

Before beginning the actual coding, the coders trained themselves by studying and discussing the content categories, coding a sample of position descriptions, and calculating their inter-coder agreement. The coders did not begin the actual coding of position descriptions until their inter-coder agreement exceeded the minimally acceptable standard of $80 \%$ (Riffe and others, 1998).

When both coders completed the coding for a region, we calculated inter-coder agreement for the region overall and for each position description. For any position description on which the coders' level of agreement was less than $80 \%$, the coders discussed the coding of that description and reached a consensus about what the codes should be. Once the coders finalized their consensus coding for a region, we recalculated the overall inter-coder agreement. The average initial intercoder agreement was $90 \%$ (range $=85-94$ ), and the average consensus intercoder agreement was $92 \%$ (range $=90-96$ ). We also calculated kappa for each content category within each region. Kappa is an additional measure of inter-coder reliability that takes into account the possibility for chance agreement (Riffe and others, 1998). The majority of the kappa values were significant, indicating a sufficient level of agreement: The kappa values that were lower and non-significant most often occurred in content categories that were rarely used by the coders. The agreement levels along with the kappa values are provided for each region in the Regional Appendices (Appendix 3A). We used the primary coder's data as modified by the consensus discussions in the analyses. 
Table 3.3. Latent content category terms.

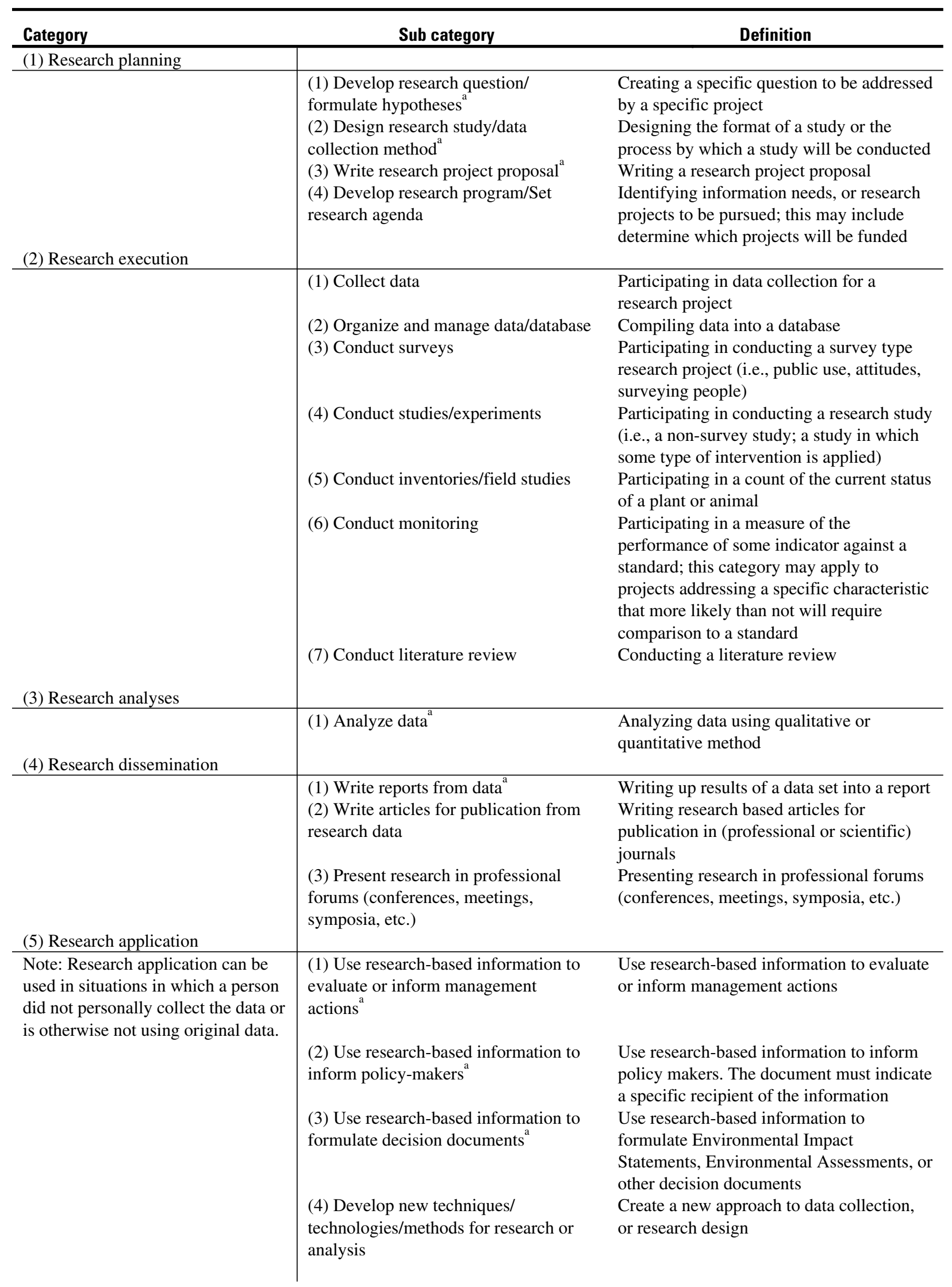




\begin{tabular}{|c|c|c|}
\hline $\begin{array}{l}\text { Category } \\
\text { (6) Research collaboration }\end{array}$ & Sub category & Definition \\
\hline \multirow{2}{*}{ (7) Knowledge/skill/ability required } & $\begin{array}{l}\text { (1) Collaborate with non-FWS } \\
\text { personnel on research projects } \\
\text { (2) Supervise or coordinate other FWS } \\
\text { employees on research projects } \\
\text { a } \\
\text { (3) Identify sources of funding for } \\
\text { research } \\
\text { (4) Write research funding proposals }\end{array}$ & $\begin{array}{l}\text { Working with any one outside of the FWS } \\
\text { on a research project in any capacity } \\
\text { Supervising or coordinating among other } \\
\text { FWS employees in any aspect of the } \\
\text { research process } \\
\text { Identifying sources of funding for research } \\
\text { Writing research grant or other funding } \\
\text { proposals }\end{array}$ \\
\hline & $\begin{array}{l}\text { (1) Knowledge/skill/ability - statistical } \\
\text { data analysis } \\
\text { (2) Knowledge/skill/ability - research } \\
\text { methods } \\
\text { (3) Knowledge/skill/ability - statistical } \\
\text { software } \\
\text { (4) Knowledge/skill/ability - document } \\
\text { preparation }\end{array}$ & $\begin{array}{l}\text { This position requires knowledge/skill/ } \\
\text { ability in data analysis techniques and } \\
\text { methods } \\
\text { This position requires knowledge/skill/ } \\
\text { ability in research methods, including data } \\
\text { collection techniques and study design } \\
\text { This position requires knowledge/skill/ } \\
\text { ability in use of statistical software } \\
\text { packages } \\
\text { This position requires knowledge/skill/ } \\
\text { ability to write reports, papers, manuscripts } \\
\text { based on research for dissemination or } \\
\text { publication }\end{array}$ \\
\hline
\end{tabular}

a This category reflects an item included on the list of activities that constitute involvement in research on the FWS survey.

\section{Results}

\section{Manifest Content Analysis}

We asked four questions regarding the link between keywords and publication status (published or not) of the individual in the position. We analyzed the data at an aggregate level (all FWS) as well as at regional levels. Our interest in these analyses was to determine if someone looking at this relationship within a particular region would come to the same conclusion as someone looking at this relationship within another region. We were not particularly interested in the degree to which this relationship differs across regions (i.e., is the relationship stronger in Region 3 than it is in Region 5). Therefore, rather than conducting an omnibus test to detect differences among regions, we decided to treat each region as a separate data set and conduct separate analyses within each set.

For all of these analyses, we believed that the implication of making a Type II error was much more problematic than making a Type I error within the context of this study. This component of the study is exploratory in nature and we believe that some leeway in statistical interpretation is acceptable. The consequences of Type I errors in this situation are negligible. It is highly unlikely that a significant relationship between a keyword and publication status, even if found in error, would have any impact on the science capacity of the FWS or even on the manner in which position descriptions are written. If the FWS did decide to revise position descriptions, it is likely that the agency would evaluate the PDs more comprehensively. Finally, we anticipated that the effect size of the relationship between these variables would be quite small. Although it seems that the sample size is more than adequate overall, it is barely adequate for detecting a small effect size (Murphy and Myors, 1998). In fact, at the regional level, the sample size is insufficient to detect any relationship smaller than a moderate effect size. Any attempt to minimize Type I error, such as an adjustment to the family-wise error rate, would further decrease statistical power (Murphy and Myors, 1998). For the reasons listed above, we opted to evaluate each statistical test with a $P$-value of .05 , even though doing so is contradictory to what most people understand as being the traditional approach to hypothesis testing. The complete results of these analyses are available in Appendix 3B. 
1. Is there a relationship between the presence (or absence) of each keyword in a position description and publication status? We used the Chi square measure of association for this analysis. At the aggregate level, the presence of four of the keywords (analysis, monitoring, research, and scientific) was significantly related to publication status. However in each of these cases the effect size (phi) was small indicating a weak relationship. Interestingly, of these four words only the term "research" had significant associations with publication at the regional level; "research" was related to publication status in regions 3 and 6. The words "evaluation" and "studies" showed significant relationships with publication status only in Region 3.

2. Is there a relationship between the sum of each keyword appearing at least once in a position description (range $=0-10$ ) and publication status? We used a t-test to evaluate this relationship. The two primary assumptions underlying use of a t-test are normality in distribution of the data and homogeneity of variance. We were not concerned about the normality issue because the t-test is robust to violation of this assumption when the sample size is large (Hays, 1988). Levene's test for equality of variances indicate that for this analysis we can assume equal variance for the two groups (published and non-published) at the aggregate as well as regional level. The results of t-test analyses indicate that the sum of the keywords was significantly related to publication at the aggregate level, as well as in Region 3.

3. Is there a relationship between the frequency of each keyword in a position description and publication status? We checked these data for equal variances for the two groups (published and non-published). When Levene's test for equality of variances indicated that the two groups were not equal we used Welch's t-test for unequal variances, otherwise we used a series of one-way analysis of variance (ANOVA) tests to determine whether or not an individual had published was related to the keyword frequency. At the aggregate level, publication status showed small but significant relationships with the frequencies of five of the keywords (analysis, monitoring, research, scientific, studies). The aggregate results were not consistent with regional results. However, of the five keywords, three of them had significant relationships with publication when analyzed at the regional level (analysis Regions 5 and 7; research - Regions 1 and 6; scientific - Regions 6 and 7). Additionally, two keywords demonstrated a significant relationship at the regional level (evaluation - Region 3; national - Region 5) but not at the aggregate level.

4. Is there a relationship between the sum of the frequencies of all keywords in a position description (all keyword frequencies summed) and publication status? We used ANOVA to evaluate the relation between the grand sum of keywords and publication status. We calculated Levene's test for equality of variances because homogeneity of variance is a critical assumption of the ANOVA statistic. The variance for the aggregate FWS was unequal and therefore we calculated a Welch's t-test. Variances were sufficiently similar for all of the regions to permit the use of ANOVA. The relationship was significant at the aggregate level and at the regional level for Regions 5 and 6.

We can identify some keywords in position descriptions that distinguish between people who have published and people who have not published, but only for some FWS regions. The keywords that distinguish between position descriptions of publishers and non-publishers differ across regions. A number of keywords showed significant relationship with publication at the aggregate level. However, in these cases, the effect size was small. It is likely that we found statistical significance for some of these keywords at the aggregate level as an effect of the large sample size, which increases the statistical power of our tests.

We conclude that evaluation of the surface level content of the position descriptions is likely to be an unreliable method for identifying positions involved in conducting research, particularly if one is comparing positions across regions. Conducting a closer examination of the content of the position descriptions provided us with more direct and more detailed information about the research content of the positions.

\section{Latent Content Analysis}

We calculated the frequencies for each content category. We also conducted Chi square analyses to determine if there were relationships between category content and publication status, GS-level, or occupational classification. The overall latent results, at both the aggregate level, for all of FWS-less Region 4, and at the regional level, are provided in Appendix 3C. Breakdowns for the overall FWS and for each region are provided separately in the Regional Appendices (Appendix 3A). For some of the analyses at the regional level, specifically the analyses of the relation between content categories and GS-level or occupational classification, the sample sizes within cells are too small to provide statistically reliable results. We provide frequencies at the regional level for the interest of the 
regions, but we are unable to determine statistical relationships between GS level and latent content or between occupational classification and latent content.

Of all of the information that the latent content analysis yielded, the most useful is the frequencies with which each content category appeared in the sample of position descriptions. A list of the categories and their frequencies for the overall FWS, in order of most to least frequent, is provided in Table 3.4. The most frequent categories coded in the position descriptions were knowledge, skill, and ability for research methods (7-2) and data analysis (7-1), confirming the presence within the FWS for conducting research. The third most frequent category, application of research information to management actions (5-1), supports the mission of the FWS as a management agency rather than a research agency. However, the fact that the next three most frequent content categories, designing studies (1-2), analyzing data (3-1), and collecting data (2-1), are all related to conducting research reinforces the contention of many in the FWS that, while basic research may not be part of their mission, applied research is an essential component of resource management.

Table 3.4. Content categories organized by frequencies, number of position descriptions coded $=244$.

\begin{tabular}{lcc}
\hline Coding category & Present in PD & Not present in PD \\
\hline (7-2) Knowledge/skill/ability required - research methods & $117(48)^{\mathrm{a}}$ & $127(52)^{\mathrm{a}}$ \\
(7-1) Knowledge/kill/ability required - data analysis & $104(43)$ & $140(57)$ \\
(5-1) Research application - management actions & $103(42)$ & $141(58)$ \\
(1-2) Research planning - design study & $96(39)$ & $148(61)$ \\
(3-1) Research analyses - analyze data & $95(39)$ & $149(61)$ \\
(2-1) Research execution - collect data & $93(38)$ & $151(62)$ \\
(2-5) Research execution - conduct inventories & $82(34)$ & $162(66)$ \\
(6-1) Research collaboration - non-FWS & $78(32)$ & $166(68)$ \\
(6-2) Research collaboration - supervision & $59(24)$ & $185(76)$ \\
(7-4) Knowledge/skill/ability required - document preparation & $58(24)$ & $186(76)$ \\
(4-1) Research dissemination - write reports & $57(23)$ & $187(77)$ \\
(1-4) Research planning - develop research program & $49(20)$ & $195(80)$ \\
(2-6) Research execution - conduct monitoring & $46(19)$ & $198(81)$ \\
(2-2) Research execution - database management & $29(12)$ & $215(88)$ \\
(4-2) Research dissemination - publication & $28(12)$ & $216(89)$ \\
(7-3) Knowledge/skill/ability required - statistical software & $27(11)$ & $217(89)$ \\
(4-3) Research dissemination - presentation & $21(9)$ & $223(91)$ \\
(5-4) Research application - new techniques & $21(9)$ & $223(91)$ \\
(1-3) Research planning - write proposal & $12(5)$ & $232(95)$ \\
(2-4) Research execution - conduct studies/experiments & $11(5)$ & $233(96)$ \\
(2-7) Research execution - conduct literature review & $11(5)$ & $233(96)$ \\
(5-2) Research application - policy makers & $9(4)$ & $235(96)$ \\
(5-3) Research application - decision documents & $7(3)$ & $237(97)$ \\
(6-4) Research collaboration - write funding proposal & $6(3)$ & $238(98)$ \\
(1-1) Research planning - develop question & $4(2)$ & $240(98)$ \\
(6-3) Research collaboration - identify funding & $3(1)$ & $241(99)$ \\
(2-3) Research execution - conduct surveys & $2(1)$ & $242(99)$ \\
\hline & & \\
Percentages in parentheses. & & \\
& & \\
\end{tabular}

At the other end of the spectrum, the content category that was coded the least frequently was conducting surveys (2-3). This is probably the result of the category definition. We defined surveys as being targeted towards people. There were many position descriptions that included statements regarding conducting wildlife surveys; those statements were coded as conducting inventories/field studies (2-5). Two of the infrequent content categories dealt with obtaining research funding, (6-3) and (6-4). Given that the emphasis of the FWS is on management rather than research, it is not surprising that these content areas would occur only rarely in position descriptions. Similarly, content category (1-1) was defined as defining a research question or formulating hypotheses, and would be more likely to occur in a position description of someone who was conducting basic rather than applied research.

Due to some sparseness in our tables, we used the Fisher's Exact test to evaluate the results of these analyses. Our analyses to determine if each content category related to publication status yielded significant results for the eight categories listed in Table 3.5. Specific statistical information regarding these relationships is provided in the "All FWS" portion of the regional appendix (3A). The presence of these content categories in a position description is associated with an increase in the likelihood that an individual has published. This analysis also 
provides a form of validation for our content categories. Our intent was for the categories to capture research-related content. Our assumptions that the categories and coding would capture what we intended are supported when categories that have content specifically related to the process of conducting and publishing research relate statistically to whether or not a person has published.

Similarly, our categories contain content at varied levels of complexity. We therefore expected and confirmed that some of the content categories would show differential relationships with GS level. In other words, we expected the proportion of position descriptions containing a given category to vary across GS levels. The sample of position descriptions we coded contained position descriptions at GS grades 7, 9, 11, 12, 13, 14, and 15, with the majority of descriptions concentrated at grades 11,12, and 13. Due to sparseness in the tables, we conducted analyses only with data for GS levels $11-14$. Even with this reduction, some categories occurred too infrequently to permit statistical analysis. The nine categories in Table 3.6 related significantly to GS level.

Table 3.5. Categories with significant relationships to publication status.

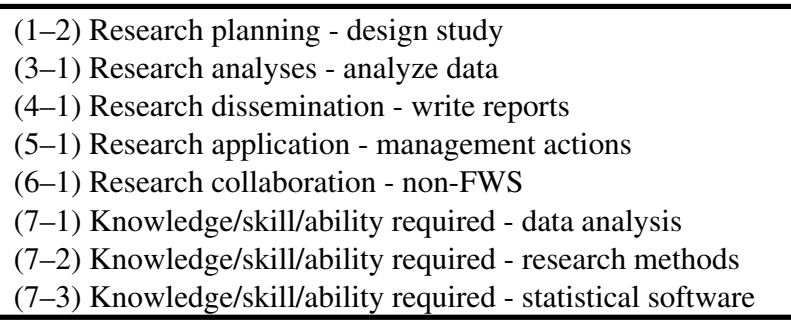

Notes. Categories listed appeared with greater frequency in the position descriptions of published versus non-published individuals.

Table 3.6. Categories with significant relationships to GS-Level in the range of GS 11, 12, 13, 14 .

(1-2) Research planning - design study

(2-1) Research execution - collect data

(2-5) Research execution - conduct inventories

(2-6) Research execution - conduct monitoring

(3-1) Research analyses - analyze data

(4-1) Research dissemination - write reports

(4-2) Research dissemination - publication

(7-1) Knowledge/skill/ability required - data analysis

(7-4) Knowledge/skill/ability required - document preparation

Table 3.7. Categories with significant relationships to occupational classification.

(1-2) Research planning - design study

(2-1) Research execution - collect data

(2-5) Research execution - conduct inventories

(2-6) Research execution - conduct monitoring

(3-1) Research analyses - analyze data

(4-1) Research dissemination - write reports

(4-2) Research dissemination - publication

(5-4) Research application - new techniques

(6-1) Research collaboration - non-FWS

(7-1) Knowledge/skill/ability required - data analysis

(7-2) Knowledge/skill/ability required - research methods

Due to the varied nature of positions in the FWS, we expected and confirmed that some of the content categories would show differential relationships with occupational classification. The occupational classifications differed greatly in terms of the work conducted by individuals in each classification. We expected that each content category would not be equally applicable to all occupations. Due to sparseness in the distribution of the data, we conducted analyses only with data for the most common Occupational Classifications: 401 (General Biological Science; 480 (Fish and Wildlife Administration); 482 (Fishery Biology); 485 (Wildlife Refuge Management); and 486 (Wildlife Biology). 
Even with this reduction, some categories occurred too infrequently to permit statistical analysis. The 11 categories listed in Table 3.7 were significantly associated with occupational classification. More detailed information on both the GS level and the occupational classification analyses are included in the "All FWS" portion of the regional appendix (Appendix 3A).

\section{Discussion}

We conclude from the information we obtained from the Research Positions task that while clearly there are positions in the FWS that involve conducting research, there is no simple and direct method of identifying them. We found no data in the FPPS report to enable identification of researchers. In fact, we learned that a person who used the functional classification for research to pinpoint researchers would likely be misled. Interviews with the Regional Personnel Officers suggested that there was no easy way to identify researchers and that differences among regions may prevent such identification. Similarly, the word count method of the manifest content analysis yielded results that varied across regions.

The analysis of the latent content of the position descriptions provided useful information regarding research-related work done by FWS employees. Nearly half of the position descriptions we coded indicated a requirement for knowledge, skill and ability related to research methods and data analysis. However, we still lack a direct means to identify researchers. Many of the position descriptions of non-published individuals contained research-related content, so looking for publications is not a fool-proof way to identify researchers. Research content was not restricted to the position descriptions of a particular GS level or a particular set of occupational classifications. Even within classifications, some position descriptions would indicate research content and others would not. Our best guess, given the information we have, is that factors of the level of experience, capability, and possibly personal interest converge with occupational type, culture of region, and location to create opportunity to conduct and publish research (see Chapter 4 regarding attitudes and expectations of employees).

Although we cannot offer a direct method for identification of researchers within the FWS, we can state that the content of the position descriptions clearly indicates that research, primarily research directed toward answering questions important for management, is being conducted by some FWS employees as part of their jobs. Given the content of the position descriptions, we assert with confidence that the FWS is an agency with substantial research capability. 


\section{Chapter 4}

\section{Survey of Employees in Professional Series Positions within the U.S. Fish and Wildlife Service}

\section{Introduction}

The objective for this task was to ascertain the attitudes and perceptions of employees involved in research regarding the obstacles and opportunities for research. We designed the survey to answer the following questions: What is the nature of current research assignments? What resources are available for research studies? How are research results reported? How are research products used by managers? What are the obstacles and opportunities for conducting research?

\section{Methods}

\section{Participants}

Our goal was to select a sample of employees who had job titles and grades that made them candidates to conduct research. We queried the Federal Personnel/Payroll System (FPPS) for FWS employees and limited this query to professional positions (including biologists, ecologists, hydrologists, economists, etc); this procedure eliminated administrative, technical, clerical, and other positions. Subsequently, we created a database of all FWS employees who were obtained from this query. We defined this database of employees as our population $(N=$ $3,939)$; this is the total population of FWS employees who hold positions that might allow them to conduct research. We used standard probability statistics to determine that a sample size of 843 employees would allow us to say with 95\% confidence that the error attributable to sampling and other random effects would be plus or minus $3 \%$ for the overall survey. In survey research, it is common to have a response rate in the range of $65 \%$; therefore, in order to obtain at least 843 respondents, and to make sure our completed sample was representative of the population, we administered the survey to at least 1,297 individuals.

We also wanted to ensure that the eight FWS regions (Regions: 1-7, and 9) were proportionately represented in the survey sample. We stratified the random sample so that the number of participants in the survey sample from each region represented the proportion that each region makes up of the study population. We calculated the percentage of employees that each region contributed to the entire study population. We established parameters within $S P S S^{\mathrm{tm}}$ so that the program would randomly select a percentage of employees from each region that corresponds to the region's percentage of the study population. For example, Region 1 makes up approximately $25 \%$ of the total study population of potential FWS researchers. We used the SPSS ${ }^{\mathrm{tm}}$ software to randomly select 353 employees from Region 1 so that employees from this region would make up approximately $25 \%$ of the study sample. Once we made certain that the appropriate percentage of participants from each region was represented in the study sample, we ended up with a sample size of 1,392.

In addition to the stratified random sample of potential FWS researchers, we identified a group of FWS employees who had published at least one article in a peer-reviewed, scientific journal since 1995 while they were employees of the FWS (see Chapter 2). This search process resulted in 496 names. Out of this group of "known" researchers, we included in our study sample those who were in professional series positions and for whom we had email addresses $(n=471)$. Adding the known researchers to the random sample of 1,392 professional series employees (Table 4.1) resulted in a total sample size of $1,863$. 
Table 4.1. Description of sampling design.

\begin{tabular}{r|cc}
\hline & \# of individuals receiving the survey & \% of overall study sample \\
\hline Region 1 & 353 & 25 \\
Region 2 & 157 & 11 \\
Region 3 & 149 & 11 \\
Region 4 & 214 & 15 \\
Region 5 & 132 & 10 \\
Region 6 & 176 & 13 \\
Region 7 & 93 & 7 \\
Region 9 & 118 & 9 \\
& & \\
Known researchers & Total $=1,392$ & \\
& 471 & \\
\hline
\end{tabular}

\section{Survey Development}

Our objective for the survey instrument was to ask questions that would ascertain the attitudes and perceptions of employees involved in research regarding: (1) the nature of their research assignments, (2) the resources available for their research activities, (3) how their research results are reported, (4) how their research results are used, (5) both the obstacles and the opportunities for conducting research, and (6) the level of satisfaction they experienced associated with working in a research capacity at the FWS. We wrote a number of questions to map onto these objectives. Two pre-tests of the survey instrument were conducted to improve the survey.

The first pre-test of the survey instrument took the form of a review by FWS regional research coordinators who were asked to either pre-test the survey instrument themselves or identify someone in their region who would be willing to do so. Specifically, they were asked to serve as a pre-test panel by completing the questionnaire and recording the time required and noting any difficulties they encountered. There were also encouraged to provide specific feedback on any of the items encountered on the survey. Seven individuals served on the first pre-test panel, one from Region 5, five from Region 6, and one from Region 9. The second pre-test was given to five field office employees of the FWS. These employees were asked to complete the questionnaire, record the time required, and comment on any problems encountered. The results from these employees were examined to ascertain whether or not significant problems could be identified. Finally, three scientists outside of the USGS were asked to review the survey instrument regarding its content, structure, and wording. The comments and suggestions from both pre-tests and the peer review were incorporated into the final survey instrument.

\section{Procedures}

Dillman's (2000) Tailored Design Method was followed to conduct the survey. Data were collected primarily via an interactive web page located on a server housed at the Fort Collins Science Center. Because most of the employees of the FWS have access to computers connected to the Internet, we followed Dillman's method by sending email invitations to the FWS employees included in the study sample that asked them to access a web page to complete the questionnaire. We provided three follow-up invitations via email. Because we recognized that some remote FWS locations would not have adequate Internet access and anticipated that we might encounter technical difficulties in administering an Internet survey, we provided a back-up procedure. All of the study participants were given the options of either downloading a PDF version of the questionnaire or requesting that a hard copy of the questionnaire be mailed to them. Before the survey began, notification was given to employees indicating that the study was an official activity of the FWS. A total of 1,149 respondents (88.9\%) used the Internet to complete the questionnaire, and $144(11.1 \%)$ either requested a paper questionnaire or downloaded the PDF file and submitted the questionnaire through the mail. The overall response rate for this survey, including Internet and mail-back, was $69.4 \%(n=1,293$; Table 4.2). 
Table 4.2. Description of sample by region of the Fish and Wildlife Service.

\begin{tabular}{r|cc}
\hline & \# of individuals completing the survey & \% of study sample \\
\hline Region 1 & 233 & 25.8 \\
Region 2 & 89 & 9.9 \\
Region 3 & 95 & 10.5 \\
Region 4 & 135 & 15 \\
Region 5 & 95 & 10.5 \\
Region 6 & 134 & 14.9 \\
Region 7 & 64 & 7.1 \\
Region 9 & 56 & 6.2 \\
& Total =901 \\
Known researchers & (+ 24 who left region blank) \\
& Total number of respondents = 1,293 \\
\hline
\end{tabular}

The average age of survey participants was 44.5 years, with a standard deviation of 8.8 years. Sixty-six percent of the sample was male. The participants have worked for the FWS an average of 12.8 years, with a standard deviation of 8.9 years. We asked participants to designate their highest completed academic degree and found that $37 \%$ had completed a Bachelor's Degree, $49 \%$ had completed a Master's Degree, and $11 \%$ had completed a Doctor of Philosophy Degree. The other 3\% of the sample completed another type of degree (e.g., High School diploma, Associate's Degree, Medical Degree, etc.). We conducted a check for non-response bias by contacting via telephone a sample of 31 people who had not answered the survey (Text Box). Although there were minor differences among the demographic variables of the non-respondents and survey respondents, non-response bias was not detected.

\section{Follow-up phone interview}

We chose a sub-sample of our original study sample for a phone interview. The purpose of this phone interview was to examine whether non-response bias occurred for the survey. Non-response bias occurs when survey respondents provide different responses than would have been provided by sample members who did not respond. Fifty individuals, who were part of our study sample but did not respond to the survey, were randomly selected for a follow-up interview. Work phone numbers could only be obtained for 31 of these 50 individuals, and ten of those phone numbers proved to be invalid (resulting a follow-up sample $=21)$. The non-respondents were slightly older $($ mean $=46.6)$ than the survey respondents $($ mean $=44.5)$ and more likely to be male (76\%) than the survey respondents (66\%). The average non-respondent was a GS12 with a higher average number of years of service (mean $=14.8)$ than the survey respondents $(m e a n=12.8)$. The non-respondents had a variety of occupational titles: fish and/or wildlife biologist $(n=9)$, refuge manager $(n=3)$, geneticist $(n=1)$, project leader $(n=1)$, fire management officer $(n=1)$, lead instructional specialist $(n=1)$, fisheries coordinator $(n=1)$, biology technician $(n=1)$, and others $(n=3)$.

Of those who told us why they did not answer the questionnaire 52\% $(n=11)$ said it was a matter of available time. Nineteen percent $(n=4)$ said that they felt the study survey was not relevant to them. One of the non-respondents $(5 \%)$ had technical difficulty with the on-line survey. Finally, $24 \%(n=5)$ of the non-respondents chose the "other" option for why they did not respond to the survey. Of the individuals who responded with the "other" option, one said that she did not respond because she was on maternity leave. Another did not respond because of problems with an office computer. Two said that they did not respond because they were skeptical about the usefulness of the survey results. A fifth non-respondent reported being told by a supervisor not to respond to the survey.

It appears that no non-response bias occurred for the study survey. The fact that the average age of the non-respondents was slightly higher than for the survey respondents may raise red flags for some, possibly indicating that older individuals were less likely to participate in the survey because it was presented as an on-line survey. However, $19 \%(n=4)$ of the non-respondents were in their early 30s. Furthermore, only one non-respondent said that the reason for not participating in the survey was due to technical difficulties and this individual was between 30 and 40 years of age.

Although a higher percentage of males were in the non-respondent group, there is sparse literature about why men would be less likely to participate in the survey than women. Past researchers (Dillman and others, 2001) found that for household surveys, non-respondents were more likely to be female, and that a higher proportion of males respond to web questionnaires (http://survey.sesrc.wsu.edu/dillman/papers.htm).

Another difference is higher average length of service in the FWS among the non-respondents. It is possible that individuals who have worked for the FWS for a long time were less likely to participate in the study survey. However, it is worth noting that out of the two non-respondents who said that they did not participate because they were skeptical that the results would be useful, one had 29 years of service and the other 12 years. 
We asked participants if their research responsibilities had changed in the past three years to include more or less research responsibility. We found that $9 \%$ moved to a job within the FWS that included more research responsibilities, $12 \%$ moved from a job within the FWS that included more research responsibilities, $13 \%$ remained in their current jobs but now have added research responsibilities, $9 \%$ remained in their current jobs but now have fewer research responsibilities, and 56\% indicated that none of the options applied to them. From this information it can be concluded that approximately $21 \%$ of the survey participants reported that their research responsibilities had changed to include fewer research responsibilities, while 22\% reported that their research responsibilities had changed to include more research responsibilities.

\section{Findings}

\section{Overall Feedback on Survey}

At the end of the survey instrument all respondents were asked "Please tell us if you have any other comments, suggestions, or information." Two hundred and fifty respondents answered this open-ended question (Appendix 4A). The category with the most responses included comments regarding research in the FWS. That category accounted for $52 \%(n=130)$ of the responses to this open-ended question. We subdivided the category into subgroups. Of those, the most responses were received about the necessity of research in the FWS. Twenty-one percent $(n=53)$ wrote about this aspect. They said things such as: "Fish and Wildlife should be involved in more monitoring activities," "The FWS needs to upgrade their research," "Encourage more research without jeopardizing our management responsibilities." In a longer statement, one respondent made the following observations:

I believe that data gathering through responsible research should be top priority for the FWS. The FWS cannot responsibly update the status of species or resources under our jurisdiction without appropriate data. Biologists should be directed and encouraged to coordinate, lead, and/or supervise research activities or research possibilities (e.g., partnerships, contracts, or grants) that would better assist the FWS in making properly-informed management and recovery decisions. Without the necessary tools and support, FWS biologists cannot provide the Agency with the best available information to conserve and enhance fish and wildlife resources.

A similar set of sentiments was expressed about the resources needed to conduct research in the FWS (18\%; $n=46)$. One respondent said, "I partner like crazy all the time, [to get research resources] but that is still not satisfactory, it isn't working." A longer response highlighted specific concerns:

Research is not important or emphasized by the RO. Participation in professional societies and symposia is not encouraged or supported. Individual Development Plans are left unsigned/ unapproved and in some cases been used as an excuse not to permit attendance/participation a professional conferences because they are not signed. It is critical and essential for those of us in natural resource management and research to stay in touch with our respective fields and all the information that is being generated today. I find the Service ultra conservative in its attitude and philosophy towards research and professional society participation of its employees.

Other comments in this category addressed a conundrum of publicly-funded research:

Research is needed, but we need to get our house in order. Adequate funding needs to be obtained for core activities before funding is spent on research activities. If core funding is not obtained how can a non-core activity like research even be considered? The research needs to be linked to a core activity so something useful could possibly come out of it.

As one respondent said, "Increased base funding would be nice, but I am sure everyone says that!"

Also in the category of research within the FWS we received responses about perceptions of the FWS as a research agency $(10 \% ; n=24)$ and outside influences on research $(6 \% ; n=15)$. About FWS as a research agency, one respondent observed the following: "Most positions in the Service are not oriented towards research. In general, we provide oversight of program funding, review of actions, and evaluate impacts." Another said, "I have been told more than once that "FWS does not do research...." Some comments were very pointed: 
When I asked four other employees if they were filling out this survey, they laughed at me and said 'research in FWS is a joke,' and 'why bother - they will just add a little spin control and it will all mean nothing because "everything is fine." If you complain, you get passed over for advancement. FWS is amassing a large bobble-head collection of biologists under the current regime.

The comments about outside influences on research were also sharp. As the observations of one respondent illustrate, this is a multi-level concern:

Politics plays way too much of a role in our agency's decisions and in funding from D.C. Hiring practices weigh heavily on nepotism and cronyism and most offices are very incestuous. The managers at every level are populated by climbers who show up to work to work on their next promotion, not working to recover listed species and their habitats.

Others said, "the politicization of science is extremely disturbing, and I object to a non-scientist defining "bad science" for me." "[T]he perception that BRD should do research... leaves the perception that the Service does "hobby science." "Policies are instituted based on political influence, not biological facts." One respondent summed the category this way: "A scientifically-based management agency without a R\&D arm is left to accept new and evolving information $\mathrm{w} / \mathrm{n}$ the context of political priorities, budgeting shortfalls, agency ownership issues which is not conducive to 'good science' or the scientific method."

Twenty-five percent of the comments we received were about the questionnaire itself or about the survey. Of those, $6 \%(n=63)$ were generally positive, thanking us for conducting the survey and $4 \%(n=11)$ were generally negative. The negative comments included statements such as "Research should be better defined for your survey purposes." "Do not request any personal info." "The website was slow and not user friendly." A further 9\% $(n=22)$ thought that the survey was not applicable to them.

Typical statements from those respondents were the following: "My position does not involve conducting research; therefore most of the questions in this survey were left blank." "Your questionnaire is not really geared to those who coordinate research." Finally, 6\% $(n=14)$ criticized specific questions on the survey instrument.

Another main category of responses to the open-ended question concerned a respondent's personal background. Three percent $(n=7)$ described their time in the job--most were recently employed by the FWS—and $4 \%(n=9)$ described experience they had received in other agencies. Ten percent of respondents $(n=24)$ presented information about the amount of research content in their jobs. For example, three people said: "I am more of a data manager than a researcher." "I have just started in a job that has more research potential." "I value the opportunity I have to apply that which I have learned through practical experience to policy and management decisions." An additional 5\% $(n=13)$ discussed the type of research content in their jobs. One respondent said: "The research that I'm involved in project monitoring." Another commented: "My current involvement with 'research' does not include field work; thus, my responses about 'research' covers not only field data-gathering, but data and related problem analysis (for example, computer-based analysis). Two percent $(n=6)$ made a variety of comments, such as "I hope to complete my $\mathrm{PhD}$ within a year" that we categorized as miscellaneous comments about respondent's background. A general category of miscellaneous comments $(9 \% ; n=23)$ included a statement that the agency should, "Fund research that is specific to questions that need to be answered to address management issues. Do not fund research projects that study the same issue over and over, or are simply written to obtain publications. Resources are too meager to support research for research's sake." But many statements in this category simply said "none" or "good luck."

\section{Type of Research Activities}

The question of what type of research activity employees are engaged in was the first to be addressed. A list of research activities was given to the respondents and they were asked to select any of the activities that they perform in their current positions with the FWS. Table 4.3 shows the list of research activities and the number of participants who answered that they engage in each of the activities as part of their current position. 
Table 4.3. Research activities claimed by respondents.

\begin{tabular}{|c|c|c|}
\hline & $\begin{array}{l}\text { \# respondents answering } \\
\text { "yes" }\end{array}$ & $\begin{array}{l}\text { \# respondents answering } \\
\text { "no" }\end{array}$ \\
\hline Test hypotheses that further the state of scientific knowledge & $396(30.6 \%)$ & $897(69.4 \%)$ \\
\hline Design methods of data collection for research projects & $526(40.7 \%)$ & $767(59.3 \%)$ \\
\hline Write research project proposals & $485(37.5 \%)$ & $808(62.5 \%)$ \\
\hline Analyze data (statistically or qualitatively) & $697(53.9 \%)$ & $596(46.1 \%)$ \\
\hline Write reports of research results & $557(43.1 \%)$ & $736(56.9 \%)$ \\
\hline $\begin{array}{l}\text { Collect data and use those data to evaluate particular management } \\
\text { actions }\end{array}$ & $665(51.4 \%)$ & $628(48.6 \%)$ \\
\hline $\begin{array}{l}\text { Collect data and use those data to inform managers or decision- } \\
\text { makers who develop plans or policies }\end{array}$ & $672(52.0 \%)$ & $621(48.0 \%)$ \\
\hline $\begin{array}{l}\text { Collect data and use those data to provide input to environmental } \\
\text { impact statements }\end{array}$ & $237(18.3 \%)$ & $1056(81.7 \%)$ \\
\hline $\begin{array}{l}\text { Use monitoring data to detect environmental or ecological trends or } \\
\text { causes of trends }\end{array}$ & $622(48.1 \%)$ & $671(51.9 \%)$ \\
\hline $\begin{array}{l}\text { Collaborate with individuals from other organizations (e.g., U.S. } \\
\text { Geological Survey, universities) on a research project where they } \\
\text { may be the Principal Investigator, but you write some portion of the } \\
\text { final research output }\end{array}$ & $513(39.7 \%)$ & $780(60.3 \%)$ \\
\hline $\begin{array}{l}\text { Supervise or coordinate the efforts of other FWS employees who } \\
\text { are engaged in one or more of the research activities listed above }\end{array}$ & $567(43.9 \%)$ & $726(56.1 \%)$ \\
\hline
\end{tabular}

Notes. $n=1293$. These results reflect the entire survey sample, both Question Track 1 respondents $(n=981,76 \%)$ and Question Track 2 respondents $(n=312,24 \%)$.

The majority of this sample of FWS employees reported that they engage in some sort of research activity. The research activities most frequently reported by respondents included: (a) analyze data (53.9\%), (b) collect data and use those data to inform managers or decision-makers who develop plans or policies (52.0\%), and (c) collect data and use those data to evaluate particular management actions (51.4\%). Additionally, participants were asked how much of their research they would consider to be applied (i.e., collecting data with the goal of solving a practical problem) and how much of their research they would consider to be basic (i.e., collecting data with the goal of increasing scientific knowledge). The responses to these questions were in the form of a five-point Likert-type scale $(1=$ None, $2=$ Very Little, $3=$ Some, $4=$ Most, $5=$ All $)$. On average, survey respondents answered that some to most of their research is considered applied (mean $=3.89, \mathrm{SD}=1.01, \mathrm{n}=959)$ and that very little to some of their research is considered basic $($ mean $=2.43, \mathrm{SD}=1.11, \mathrm{n}=949)$.

\section{Employees Conducting Research}

There are a couple of ways in our survey instrument to answer the question of how many people conduct research in the FWS. First, anyone who answered that they engage in one of the listed research activities was considered to be someone who conducts research as part of their position. As shown in Table 4.3, 76\% of the survey sample (Question Track 1, $n=981$ ) affirmed participation in at least one of these listed research activities. A second way to answer this question is to examine the number of survey respondents who reported that a significant portion of their jobs involve research. In this sample, $38 \%$ of respondents $(n=371)$ said that at least $75 \%$ of their job involves conducting research (Table 4.4).

Table 4.4. Percent of job that involves research.

\begin{tabular}{lcc}
\hline & Frequency (\#) & Percentage (\%) \\
\hline Said that $\geq 75 \%$ of job involves research & 77 & 8 \\
Said that $\geq 50 \%$ of job involves research & 217 & 22 \\
Said that $\geq 25 \%$ of job involves research & 371 & 38 \\
\hline
\end{tabular}

Notes. Only respondents who answered Question Track $1(n=981)$ were presented this question. Eleven of the Question Track 2 respondents left this question blank. Therefore, the percentages reflect the number of respondents in each of the categories divided by the total number of respondents who answered the question $(n=970)$. 


\section{Presentation or Publication of Research Results}

A third study question asked with what frequency FWS employees publish their research. Using a Likerttype Scale ( 1 = Never, 2 = Infrequently, 3 = Frequently, 4 = Always), survey participants were asked to answer how frequently they present the results of their research in any one of a variety of outlets. When asked about publishing research in peer-reviewed scientific journals, participants' mean response was infrequently $($ mean $=1.76, \mathrm{SD}=.78)$. In Table 4.5, a list of possible sources for presenting one's research is given, along with the mean level of responses from the sample for each possible source. Seventeen percent $(17 \%)$ of the survey respondents said that they published their research in peer-reviewed scientific journals either Frequently or Always $(\mathrm{n}=949)$. Although presentation of results for all types of outlets scored as infrequent, the most frequent outlet for presentation of research products was scientific symposia or conferences $($ mean $=2.05)$, followed closely by publications of the FWS or other government agencies (mean $=1.96)$.

Table 4.5. Outlets for presentation of research results.

\begin{tabular}{|c|c|c|c|}
\hline \multirow{3}{*}{$\frac{2}{\text { Infrequently }}$} & \multirow{2}{*}{$\frac{3}{\text { Frequently }}$} & \multicolumn{2}{|c|}{4} \\
\hline & & \multicolumn{2}{|c|}{ Always } \\
\hline & Mean & St. Dev. & $n$ \\
\hline Publications of the FWS or other government agencies & 1.96 & .89 & 947 \\
\hline Peer-reviewed scientific journals & 1.76 & .78 & 949 \\
\hline Peer-reviewed professional or trade journals & 1.33 & .54 & 944 \\
\hline Non-peer-reviewed magazines & 1.33 & .51 & 943 \\
\hline Newspaper or TV media & 1.56 & .66 & 944 \\
\hline Web-based media & 1.57 & .73 & 942 \\
\hline Scientific symposia or conferences & 2.09 & .83 & 949 \\
\hline Chapters in edited books & 1.24 & .48 & 946 \\
\hline Sole-authorship books & 1.03 & .19 & 943 \\
\hline Multiple-authorship books & 1.13 & .37 & 942 \\
\hline FWS internal symposia or conferences & 1.87 & .74 & 930 \\
\hline
\end{tabular}

Notes. Only respondents who answered Question Track $1(n=981)$ were presented these items. Therefore, for each item, some respondents left the item blank.

\section{The Value of Science to FWS Employees}

Although there were no specific questions in the survey that directly asked FWS employees if they value science, one question asked participants how likely it is that they would be happier with their jobs at the FWS if they included greater opportunities for research. A second question asked how likely it is that they would be happier with their jobs at the FWS if their work included fewer research obligations. The response options for these two question were presented on a 5-point Likert-type Scale ( $1=$ Completely unlikely, $2=$ Somewhat unlikely, $3=$ Neither Unlikely nor Likely, 4 = Somewhat Likely, 5 = Completely Likely). These two items were negatively correlated ( $\mathrm{r}=$ -.31). Responses to these questions can be considered an indication of how much the employees of FWS value a research role. Table 4.6 shows average responses to these two items for this sample of employees and the percentage of respondents who answered using each response option. The survey findings indicate that employees on average are likely to be happier with greater opportunities for research (62\% answered with a 4 or 5 to the first question) and are unlikely to be happier with fewer research obligations ( $69 \%$ answered with a 1 or 2 to the second question). 
Table 4.6 Measure of the value of science to individual Fish and Wildlife Service employees as measured by asking how happy respondents would be if their jobs included more or fewer opportunities for research.

\begin{tabular}{|c|c|c|c|c|c|c|c|}
\hline \multirow{3}{*}{$\frac{1}{\text { Completely unlikely }}$} & \multirow{2}{*}{\multicolumn{2}{|c|}{$\begin{array}{c}3 \\
\begin{array}{c}\text { Neither unlikely } \\
\text { nor likely }\end{array}\end{array}$}} & \multicolumn{3}{|c|}{4} & \multicolumn{2}{|l|}{5} \\
\hline & & & \multicolumn{3}{|c|}{ Somewhat likely } & \multicolumn{2}{|c|}{ Completely likely } \\
\hline & Mean & St. Dev. & 1 & 2 & 3 & 4 & 5 \\
\hline $\begin{array}{l}\text { 1. How likely is it that you would be happier } \\
\text { with your job at the FWS if it included greater } \\
\text { opportunities for research? }\end{array}$ & 3.61 & 1.24 & $\begin{array}{c}103 \\
(11 \%)\end{array}$ & $\begin{array}{c}59 \\
(6 \%)\end{array}$ & $\begin{array}{l}205 \\
(21 \%)\end{array}$ & $\begin{array}{c}340 \\
(35 \%)\end{array}$ & $\begin{array}{c}255 \\
(27 \%)\end{array}$ \\
\hline $\begin{array}{l}\text { 2. How likely is it that you would be happier } \\
\text { with your job at the FWS if it included fewer } \\
\text { research obligations? }\end{array}$ & 1.96 & 0.96 & $\begin{array}{c}389 \\
(41 \%)\end{array}$ & $\begin{array}{c}272 \\
(28 \%)\end{array}$ & $\begin{array}{c}251 \\
(26 \%)\end{array}$ & $\begin{array}{c}31 \\
(3 \%)\end{array}$ & $\begin{array}{c}13 \\
(1 \%)\end{array}$ \\
\hline
\end{tabular}

Notes. These two questions are negatively correlated $(r=-.31, P<.001)$. For Question $1, n=962$ and for Question $2, n=956$. Only respondents who answered Question Track $1(n=981)$ were presented these questions. Therefore, some respondents left these two questions blank. Due to rounding, percentages may not equal $100 \%$.

\section{Management Support for Research}

The fifth study question asked about employees' perceptions of management support for research in the FWS. Five items on the survey addressed this question. Table 4.7 shows these five questions along with the average response of the survey participants and the percentage of participants who chose each of the response options $(1=$ Strongly Disagree to $5=$ Strongly Agree). Overall, the results indicated that the majority of survey respondents disagreed that there is management support for research at the FWS. Feelings of lack of support were expressed most strongly on measures of career opportunities ("There is a clear career path leading to advancement for me through conducting research' [mean =2.12]) and obtaining "financial resources that are necessary to conduct research from FWS funds" (mean = 2.21). Respondents were nearly neutral about management support in the form of supervisory $($ mean $=2.97)$ and agency encouragement $($ mean $=3.05)$ to be involved in research.

We know from organizational psychology literature (e.g., Robinson, 1995) that employees' perceived psychological contracts, or beliefs about promises made by the organization or expectations of the organization, can influence employees' attitudes towards their employer. One item of the survey asked respondents if they initially sought employment with the FWS because they expected research opportunities. Of the 945 individuals who responded to this item, $387(41 \%)$ responded in the affirmative. The relationships between this expectation of research opportunities and respondents' satisfaction with the FWS, intent to look for another job, and attitudes towards increasing or decreasing the research opportunities at the FWS were all examined using $t$-tests. The results indicated that general satisfaction with the FWS was lower for respondents who said that they initially sought employment with the FWS because they expected research opportunities (mean $=2.98$ ) than for respondents who said that they did not entertain such expectations (mean $=3.23 ; t_{923}=-4.71, P<.001$ ). The results also demonstrated that respondents who expected research opportunities working for the FWS were more likely to look for another job outside of the FWS (mean $=2.34)$ than respondents who did not expect research opportunities $\left(\right.$ mean $=1.67 ; t_{939}=$ 8.25, $P<.001)$. Additionally, respondents who expected research opportunities working for the FWS reported that they would be happier with their jobs if they included greater opportunities for research $($ mean $=4.09)$ as compared with respondents who did not expect research opportunities (mean $\left.=3.26 ; t_{935}=10.61, P<.001\right)$. In contrast, respondents who did not expect research opportunities working for the FWS reported that they would be happier with their jobs if they included fewer opportunities for research (mean $=2.17$ ) as compared with respondents who expected research opportunities $\left(\right.$ mean $\left.=1.68 ; t_{929}=-7.85, P<.001\right)$. 
Table 4.7. Administrative support for research.

\begin{tabular}{|c|c|c|c|c|c|c|c|c|}
\hline 1 & 2 & & 3 & & 4 & & 5 & \\
\hline \multirow[t]{2}{*}{ Strongly disagree } & \multicolumn{2}{|c|}{ Somewhat disagree } & \multicolumn{2}{|l|}{ Neutral } & \multicolumn{2}{|c|}{ Somewhat agree } & \multicolumn{2}{|c|}{ Strongly agree } \\
\hline & Mean & St. Dev. & 1 & 2 & 3 & 4 & 5 & $n$ \\
\hline $\begin{array}{l}\text { 1. There is a clear career path } \\
\text { leading to advancement for } \\
\text { me through conducting } \\
\text { research. }\end{array}$ & 2.12 & 1.12 & $\begin{array}{c}362 \\
(37 \%)\end{array}$ & $\begin{array}{c}284 \\
(29 \%)\end{array}$ & $\begin{array}{c}203 \\
(21 \%)\end{array}$ & $\begin{array}{c}89 \\
(9 \%)\end{array}$ & $\begin{array}{c}33 \\
(3 \%)\end{array}$ & 972 \\
\hline $\begin{array}{l}\text { 2. I am able to obtain the } \\
\text { financial resources that are } \\
\text { necessary to conduct research } \\
\text { from FWS funds. }\end{array}$ & 2.21 & 1.10 & $\begin{array}{c}309 \\
(32 \%)\end{array}$ & $\begin{array}{c}330 \\
(34 \%)\end{array}$ & $\begin{array}{c}183 \\
(19 \%)\end{array}$ & $\begin{array}{c}130 \\
(13 \%)\end{array}$ & $\begin{array}{c}22 \\
(2 \%)\end{array}$ & 974 \\
\hline $\begin{array}{l}\text { 3. My supervisor encourages } \\
\text { me to publish research. }\end{array}$ & 2.97 & 1.24 & $\begin{array}{c}163 \\
(17 \%)\end{array}$ & $\begin{array}{c}143 \\
(15 \%)\end{array}$ & $\begin{array}{c}358 \\
(37 \%)\end{array}$ & $\begin{array}{c}175 \\
(18 \%)\end{array}$ & $\begin{array}{c}132 \\
(14 \%)\end{array}$ & 971 \\
\hline $\begin{array}{l}\text { 4. I feel that the FWS } \\
\text { encourages me to publish } \\
\text { research. }\end{array}$ & 2.72 & 1.12 & $\begin{array}{c}173 \\
(18 \%)\end{array}$ & $\begin{array}{c}215 \\
(22 \%)\end{array}$ & $\begin{array}{c}341 \\
(35 \%)\end{array}$ & $\begin{array}{c}194 \\
(2 \%)\end{array}$ & $\begin{array}{c}47 \\
(5 \%)\end{array}$ & 970 \\
\hline $\begin{array}{l}\text { 5. I feel that the FWS } \\
\text { encourages me to get } \\
\text { involved in research. }\end{array}$ & 3.05 & 1.16 & $\begin{array}{c}113 \\
(12 \%)\end{array}$ & $\begin{array}{c}204 \\
(21 \%)\end{array}$ & $\begin{array}{c}253 \\
(26 \%)\end{array}$ & $\begin{array}{c}318 \\
(33 \%)\end{array}$ & $\begin{array}{c}82 \\
(8 \%)\end{array}$ & 970 \\
\hline
\end{tabular}

Notes. Only respondents who answered Question Track $1(n=981)$ were presented these questions. Therefore, some respondents left these questions blank. Due to rounding, percentages may not add up to100\%.

\section{Employee Satisfaction}

The question of how satisfied FWS employees are with their jobs was the sixth issue to be addressed. The survey participants were asked five questions about their satisfaction with various aspects of working at the FWS. These questions appear in Table 4.8 along with the average response to each question and the percentage of respondents who chose each of the response options. The response options to the satisfaction questions were in the form of a five-point Likert-type scale ( 1 = Completely Dissatsified to 5 = Completely Satisfied). Overall, respondents tend to be somewhat satisfied with their current positions in the FWS (mean $=3.91)$ and nearly neutral about the level of encouragement they receive from supervisors to do research $($ mean $=3.38)$ and the weight given to research as part of their individual performance evaluation (mean $=3.25)$. They are far less satisfied with the level of financial support they receive for research $($ mean $=2.54)$ and the amount of time they have to conduct research $($ mean $=2.55)$. 
Table 4.8. Measure of job satisfaction.

\begin{tabular}{ccccc}
\hline 1 & 2 & 3 & 4 & 5 \\
\hline $\begin{array}{c}\text { Completely } \\
\text { dissatisfied }\end{array}$ & $\begin{array}{c}\text { Somewhat } \\
\text { dissatisfied }\end{array}$ & Neutral & Somewhat satisfied & Completely satisfied
\end{tabular}

\begin{tabular}{|c|c|c|c|c|c|c|c|c|}
\hline How satisfied are you with: & Mean & St. Dev. & 1 & 2 & 3 & 4 & 5 & $n$ \\
\hline 1. Your current position at the FWS & 3.91 & 1.04 & $\begin{array}{c}20 \\
(2 \%)\end{array}$ & $\begin{array}{c}135 \\
(14 \%)\end{array}$ & $\begin{array}{c}47 \\
(5 \%)\end{array}$ & $\begin{array}{c}477 \\
(49 \%)\end{array}$ & $\begin{array}{c}294 \\
(30 \%)\end{array}$ & 975 \\
\hline $\begin{array}{l}\text { 2. The weight that is given to research } \\
\text { productivity in your performance } \\
\text { evaluations, in your current position at } \\
\text { the FWS }\end{array}$ & 3.25 & 1.11 & $\begin{array}{c}54 \\
(6 \%)\end{array}$ & $\begin{array}{c}184 \\
(19 \%)\end{array}$ & $\begin{array}{c}341 \\
(35 \%)\end{array}$ & $\begin{array}{c}230 \\
(24 \%)\end{array}$ & $\begin{array}{c}152 \\
(16 \%)\end{array}$ & 961 \\
\hline $\begin{array}{l}\text { 3. The level of financial support you } \\
\text { receive for research in your current } \\
\text { position }\end{array}$ & 2.54 & 1.13 & $\begin{array}{c}180 \\
(19 \%)\end{array}$ & $\begin{array}{c}347 \\
(36 \%)\end{array}$ & $\begin{array}{c}217 \\
(23 \%)\end{array}$ & $\begin{array}{c}171 \\
(18 \%)\end{array}$ & $\begin{array}{c}47 \\
(5 \%)\end{array}$ & 962 \\
\hline $\begin{array}{l}\text { 4. The level of encouragement you } \\
\text { receive from your supervisor for } \\
\text { research in your current position }\end{array}$ & 3.38 & 1.22 & $\begin{array}{c}77 \\
(8 \%)\end{array}$ & $\begin{array}{c}151 \\
(16 \%)\end{array}$ & $\begin{array}{c}280 \\
(29 \%)\end{array}$ & $\begin{array}{c}235 \\
(24 \%)\end{array}$ & $\begin{array}{c}219 \\
(23 \%)\end{array}$ & 962 \\
\hline $\begin{array}{l}\text { 5. The amount of research time you } \\
\text { have, free from other commitments, in } \\
\text { your current position }\end{array}$ & 2.55 & 1.19 & $\begin{array}{c}176 \\
(18 \%)\end{array}$ & $\begin{array}{c}378 \\
(40 \%)\end{array}$ & $\begin{array}{c}172 \\
(17 \%)\end{array}$ & $\begin{array}{c}155 \\
(16 \%)\end{array}$ & $\begin{array}{c}74 \\
(8 \%)\end{array}$ & 955 \\
\hline
\end{tabular}

Notes. Only respondents who answered Question Track $1(n=981)$ were presented these questions. Therefore, some respondents left these questions blank. Due to rounding, percentages may not add up to $100 \%$.

\section{Comparison of Known Researchers with Other Professional Series Employees}

A seventh study question was whether those participants who had been identified as known researchers (see Chapter 2) were more likely to say that they engage in basic science research activities than those not identified as researchers. We measured participation in four activities thought to be associated with traditional research: testing hypotheses, designing research methods, writing research project proposals, and writing reports of research results. On each of these activities, known researchers were more likely than other professional series employees to report that they participated in these research-related activities.

For the activity "testing hypotheses that further the state of scientific knowledge" more of the known researchers answered "yes" than answered "no," while amongst the non-known researchers a larger proportion answered no than yes to this activity (Figure 4.1). A Chi-square test revealed that these differences were statistically significant $\left(\chi^{2}=57.18, d f=1, P<.001\right)$. For the activity "design methods of data collection for research projects" more of the known researchers answered yes than no, while among other respondents more answered no than yes to this activity (Figure 4.2). A Chi-square test revealed that these differences were statistically significant $\left(\chi^{2}=45.74\right.$, $d f=1, P<.001$ ). For the activity, "write research project proposals," more known researchers answered yes than no while amongst the non-known researchers more answered no than yes to this activity (Figure 4.3). A Chi-square test revealed that these differences were significant $\left(\chi^{2}=52.84, d f=1, P<.001\right)$. For the activity "write reports of research results," more known researchers answered yes than no, while amongst the non-known researchers more answered no than yes to this activity (Figure 4.4). A Chi-square test revealed that these differences were significant $\left(\chi^{2}=53.09, d f=1, P<.001\right)$. These findings suggest that although many FWS employees participate in some kind of research activity, those with a closer involvement in designing studies and describing the findings are more likely to be the ones who are actively involved in publishing. These findings may also suggest that there exists in FWS a cadre of employees who might best be described as principally conducting research. 
Figure 4.1.

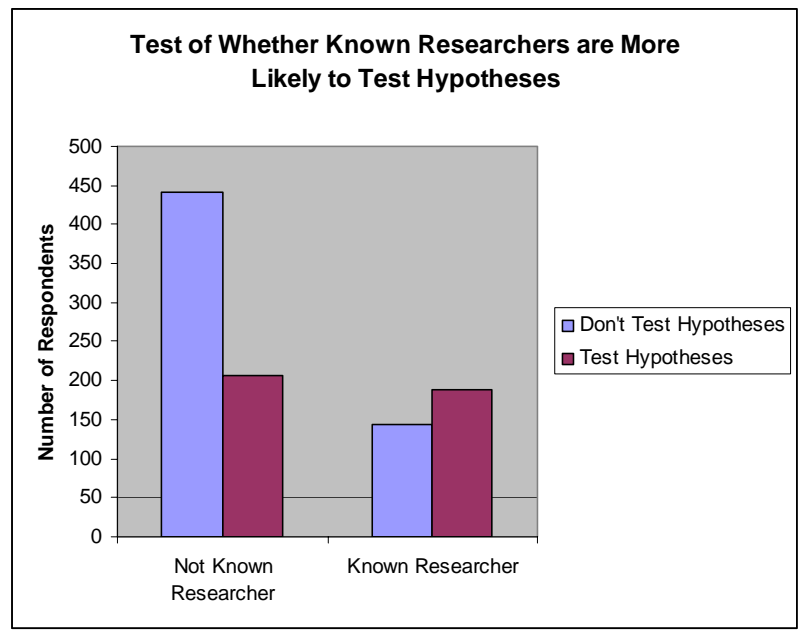

Figure 4.3.

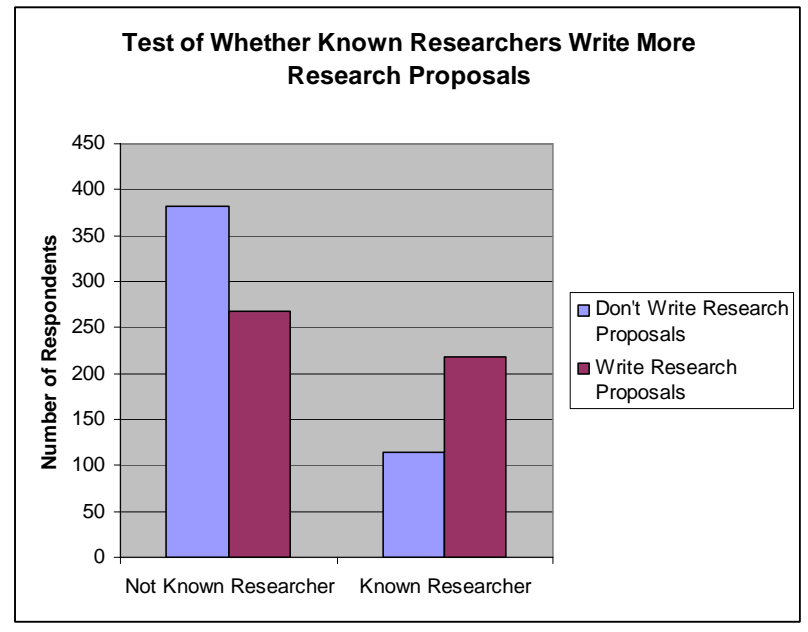

Figure 4.2.

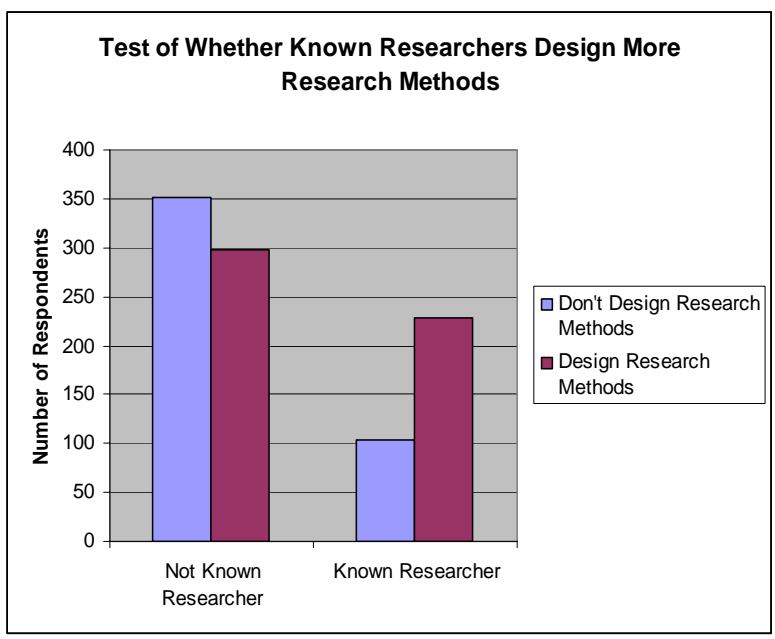

Figure 4.4 .

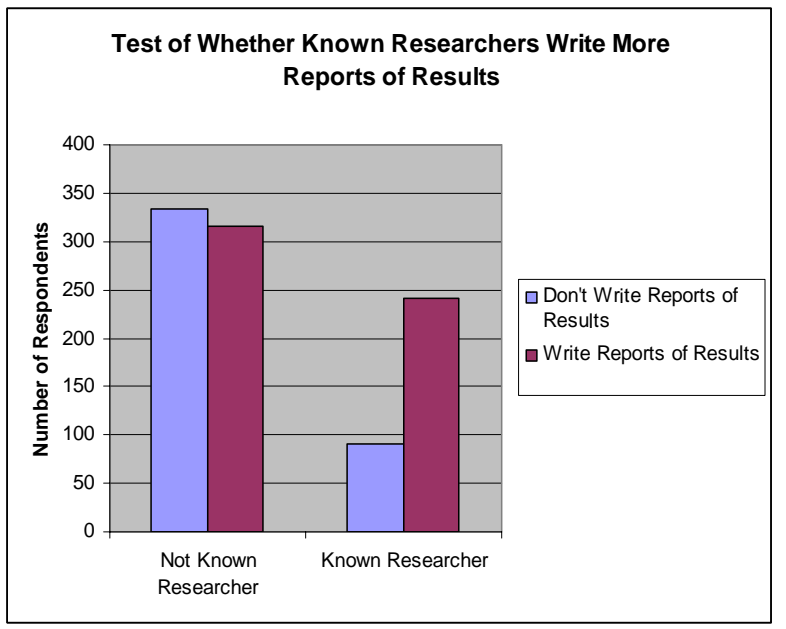

To cross-check this possibility, we asked both the known researchers and the other survey respondents what percentage of their jobs involve research. Because these data were in the form of a proportion (percentage) we graphed a box-plot of the distribution of the responses grouped by published versus non-published status in order to check for unequal variances, which is a common problem with proportional data. The box-plots indicate differences in the variances for the two groups. Therefore, all subsequent analyses using this percentage item were conducted using Welch's t-test (also known as t-test with unequal variances). The Welch's test revealed that the known researchers $($ mean $=31.12, S D=26.04)$ reported a higher mean percentage of their work involving research than did the other professional series employees (mean $\left.=21.91, S D=23.95 ; t_{1,615}=28.75, P<.001\right)$. Those who had published were more likely to report that they spend more time on research activities than were other employees (For other differences between publishers and other survey respondents, see also Appendix 4C).

Similarly, we examined whether those who claimed involvement in any particular research activity were associated with reporting a larger percentage of research in the job. The relationships between the percentage of the job involving research and all of the 11 research activities were investigated using Welch's t-test. For all but one research activity, there was a relationship between claiming the research activity and the percentage of research in the job. Those who claimed involvement in these items reported higher percentages of their jobs involving research as compared to those who did not endorse these research activity items. Only the activity "supervise or coordinate the efforts of other FWS employees who are engaged in one or more of the research activities listed above", was not related to the percentage of job involving research (Table 4.9). This finding also supports the notion that there is a cadre of scientists in the FWS whose job it is to actually conduct research endeavors. To further investigate this finding, the responses to the research activities were used to create two groups: (1) participants endorsing only the "supervise or coordinate the efforts of other FWS employees who are engaged in one or more of the research 
activities" and (2) participants endorsing any of the other research activities, excluding the supervisory activity. The first group of participants was considered "non-active researchers" and the second group was considered "active researchers." These groups were compared on general satisfaction with the FWS and on responses to an item that measured respondents' perceptions that they are expected to conduct research as part of their normal job duties. The results indicated that active researchers were more likely to perceive that they are expected to conduct research as part of their normal job duties (mean $=3.17$ ) than non-active researchers (mean $=2.17 ; t_{971}=-7.34, P<.001$ ). However, there was no group difference in level of satisfaction with working at the FWS, with regards to research $\left(t_{944}=0.42, n s\right)$. The mean level of satisfaction for the active researchers $($ mean $=3.12)$ was almost the same as the mean level of satisfaction for the non-active researchers (mean $=3.16$ ).

Table 4.9. Percentage of job involving research reported by individuals engaged in specific types of research activity.

\begin{tabular}{|c|c|c|c|c|}
\hline Research activity & $\begin{array}{l}\text { Welch's t-test } \\
\text { results }\end{array}$ & $\begin{array}{l}\text { Significance } \\
\text { level }\end{array}$ & $\begin{array}{l}\text { Mean for group } \\
\text { answering } \\
\text { "no" }\end{array}$ & $\begin{array}{l}\text { Mean for group } \\
\text { answering } \\
\text { "yes" }\end{array}$ \\
\hline $\begin{array}{l}\text { Test hypotheses that further the state of } \\
\text { scientific knowledge }\end{array}$ & $t_{1,697}=172.65$ & $P<.0001$ & 16.64 & 37.30 \\
\hline $\begin{array}{l}\text { Design methods of data collection for research } \\
\text { projects }\end{array}$ & $t_{1,916}=209.23$ & $P<.0001$ & 13.88 & 34.53 \\
\hline Write research project proposals & $t_{1.919}=132.41$ & $P<.0001$ & 16.39 & 33.79 \\
\hline Analyze data (statistically or qualitatively) & $t_{1,776}=179.53$ & $P<.0001$ & 11.63 & 30.41 \\
\hline Write reports of research results & $t_{1,932}^{1,766}=260.19$ & $P<.0001$ & 12.39 & 34.48 \\
\hline $\begin{array}{l}\text { Collect data and use those data to evaluate } \\
\text { particular management actions }\end{array}$ & $t_{1,618}=25.22$ & $P<.0001$ & 19.26 & 27.74 \\
\hline $\begin{array}{l}\text { Collect data and use those data to inform } \\
\text { managers or decision-makers who develop } \\
\text { plans or policies }\end{array}$ & $t_{1,764}=119.38$ & $P<.0001$ & 13.86 & 30.08 \\
\hline $\begin{array}{l}\text { Collect data and use those data to provide } \\
\text { input to environmental impact statements }\end{array}$ & $t_{1,412}=12.71$ & $P<.0001$ & 23.47 & 29.96 \\
\hline $\begin{array}{l}\text { Use monitoring data to detect environmental } \\
\text { or ecological trends or causes of trends }\end{array}$ & $t_{1,764}=30.69$ & $P<.0001$ & 19.31 & 28.30 \\
\hline $\begin{array}{l}\text { Collaborate with individuals from other } \\
\text { organizations (e.g., U.S. Geological Survey, } \\
\text { universities) on a research project where they } \\
\text { may be the Principal Investigator, but you } \\
\text { write some portion of the final research output }\end{array}$ & $t_{1,960}=84.33$ & $P<.0001$ & 17.62 & 31.69 \\
\hline $\begin{array}{l}\text { Supervise or coordinate the efforts of other } \\
\text { FWS employees who are engaged in one or } \\
\text { more of the research activities listed above }\end{array}$ & $t_{1,906}=1.44$ & $P=.23$ & 23.92 & 25.86 \\
\hline
\end{tabular}

\section{Job Satisfaction and Likelihood to Seek Other Employment}

We asked respondents: "How likely are you to begin looking for another job outside of the FWS in the next six months, due to a lack of opportunity for research in the FWS?" The scores on this question were represented by a Likert-type scale ranging from $1=$ Completely Unlikely to $5=$ Completely Likely. By assessing the number of respondents who reported the intent to begin looking for another job outside of the FWS in the next six months due to a lack of opportunity for research in the FWS, we hoped to explore the intensity of satisfaction or dissatisfaction present. The survey findings indicate that most of the respondents were unlikely to have this intent, because $54.6 \%$ $(n=529)$ answered that they were completely unlikely to begin looking for another job, $17.4 \%(n=168)$ indicated that they were somewhat unlikely to begin looking for another job, $12.3 \%(n=119)$ answered that they were neither unlikely nor likely to begin looking for another job, $9.5 \%(n=92)$ indicated that they were somewhat likely to begin looking for another job, and only $6.2 \%(n=60)$ answered that they were completely likely to begin looking for another job. The total number of respondents who answered this survey item represented 968 out of the 981 respondents who replied to Track 1. 
There were five items measuring job satisfaction on the survey (Table 4.8). We averaged these five measures together to form a general satisfaction variable and calculated a Pearson's Correlation Coefficient between the general satisfaction variable and the item measuring the intent to look for another job. The results indicate that as satisfaction increases, intent to look for another job decreases proportionately $(r=-.42, P<.01)$.

\section{Science Encouragement and Job Satisfaction}

Is there is a relationship between being encouraged to conduct research and satisfaction working at the FWS? Respondents used a five-point Likert-type scale ( $1=$ Strongly Disagree to $5=$ Strongly Agree $)$ to answer three items that measured encouragement to conduct research. The first item stated "my supervisor encourages me to publish research," the second item stated "I feel that the FWS encourages me to publish research," and the third item stated "I feel that the FWS encourages me to get involved in research." An individual's responses to these items were averaged to form a general Encouraged to Conduct Research variable. To measure satisfaction, survey respondents used a five-point Likert-type scale $(1=$ Completely Dissatisfied to $5=$ Completely Satisfied $)$ to indicate their level of satisfaction (See Table 4.8 for a list of the items measuring satisfaction). An individual's responses to the five satisfaction measures were averaged to form a general Satisfaction with working at the FWS variable. A Pearson's correlation coefficient was calculated that indicated these two aggregate variables are positively correlated $(\mathrm{r}=.47, \mathrm{P}<.001)$. For the whole sample, encouragement to conduct research is associated with job satisfaction.

Table 4.10. Type of science open-ended question. Responses exceed the number of respondents because some entered more than one type of research.

\begin{tabular}{lc}
\hline Type of research & Number of responses (\%) \\
\hline Education, outreach & $3(0.02 \%)$ \\
Silvaculture & $2(0.02 \%)$ \\
Invertebrate monitoring, ecology & $26(2.1 \%)$ \\
No research & $29(2.3 \%)$ \\
Hydrology & $36(2.9 \%)$ \\
Population assessments & $40(3.2 \%)$ \\
Fire ecology, management & $64(5.1 \%)$ \\
Protocols, techniques, methods & $70(5.6 \%)$ \\
Other & $89(7.1 \%)$ \\
Contaminants & $108(8.7 \%)$ \\
Vertebrate monitoring & $165(13.2 \%)$ \\
Fish ecology, behavior, habitat & $192(15.4 \%)$ \\
Habitat and/or vegetation & $207(16.6 \%)$ \\
Wildlife ecology, behavior, habitat & $217(17.4 \%)$ \\
Total of all mentions & $1248 \mathrm{a}$ \\
\hline a Does not equal 100\% due to rounding &
\end{tabular}

\section{Type of Research Engaged in by FWS Employees}

We asked respondents to indicate the type of research that they are currently doing or in which they recently had been involved. We compressed the narrative responses into 14 common categories (Table 4.10). Almost half (49.4\%) of the responses to this open-ended question were classified as fish and wildlife ecology, habitat, or behavior. Monitoring accounted for $18.5 \%$ of all reported research types, if "population assessments" is included in that category. Contaminants research accounted for $8.7 \%$ of responses to this question.

\section{Impediments or Inducements to Research}

It is evident from the answers to the Likert-type fixed response questions that respondents rated finances and availability of time as important limits on their ability to conduct research. To learn more about the impediments to research in the FWS we asked the question: "Is there any other information you would like to provide regarding 
the support, lack of support, obstacles, inducements, or resources at the FWS with regard to research?" A total of 415 respondents answered this question, which was available only to those who answered Track 1 of the survey instrument. We condensed the open-ended answers, resulting in four general categories: Support, Lack of Support, Obstacles, and Other (Table 4.11).

Table 4.11. Open-ended responses to the question: Is there any other information you would like to provide regarding the support, lack of support, obstacles, inducements, or resources at the Fish and Wildlife Service with regard to research? $(n=415)$

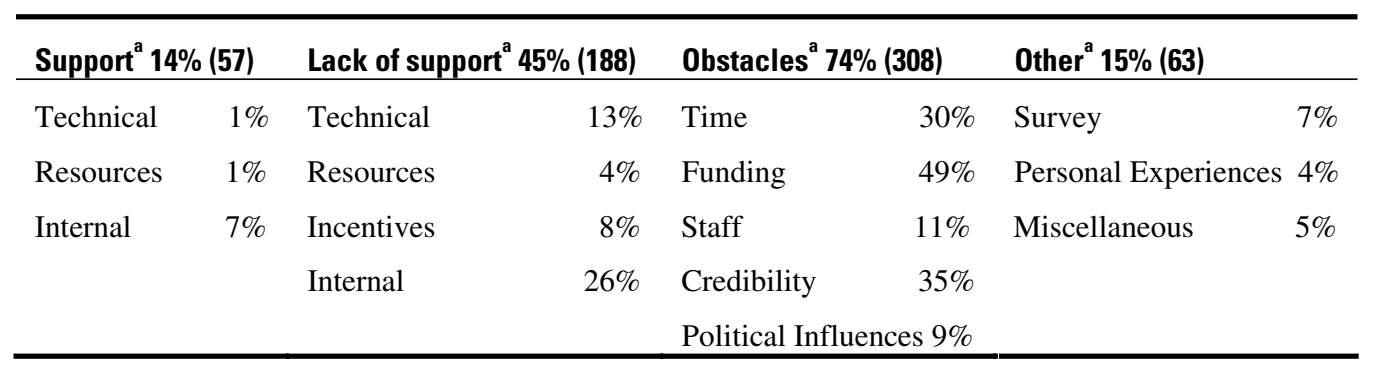

a Totals more than $100 \%$ because respondents provided multiple responses.

Fourteen percent of those who provided an answer to this open-ended question remarked upon items we categorized as "support" for research. About 1\% $(n=5)$ indicated that technical support was important. A typical respondent wrote: "The primary support that I get within the USFWS is one or two seasonal Biotech positions, which is very valuable support." Less than $1 \%(n=3)$ said resources were important. A response typical of this group was: "Recent additions to FWS library, on-line journals, and literature search [are] a Big plus for remote refuges." Internal support was mentioned by $7 \%$ of respondents to this question $(n=29)$, with a typical response being "My supervisor, who is new, is supportive of research but past supervisors were not and in fact frowned on research efforts."

Forty-five percent of respondents to this question $(n=188)$ indicated that a lack of support was evident in the FWS. Of these, $13 \%(n=55)$ said that technical issues were a problem and a typical response along these lines was "FWS does not actively support networking with their peers, participation in professional symposia and/or conferences." Only 4\% ( $n=18)$ of those who mentioned lack of support said that the problem was "resources" such as the availability of literature and reference materials. A response typical of this category was as follows: "Better access to web-based scientific journals and literature-reviewing databases would be an improvement." We categorized 8\% $(n=18)$ as falling in the realm of incentives and advancement (e.g., "I am not going to get a promotion by doing great science. There are few opportunities for field biologists to advance as biologists within the FWS.") Similarly, one respondent wrote that, "There should be more recognition for those biologists [who] publish their results in peer reviewed publications than there currently is - perhaps grade increases." We place $26 \%(n=$ 107 ) in the category of internal lack of support, which is typified by comments such as: "I am baffled at the lack of support for research - this has been the single largest frustration in my career."

Seventy-four percent $(n=308)$ were categorized as having remarked upon obstacles to conducting research. Of these 30\% ( $n=123)$ mentioned time availability (See also Table 4.8) with comments such as this: "Those that are involved with FWS research projects are rarely given adequate staff time to analyze and prepare results. More often, staff time is being usurped by administrative reports and activities." Another survey respondent observed the following: "The required paperwork and daily demands to oversee on-the-ground management actions make it very difficult to take time for reading current peer reviewed journals, and for data analysis and writing." Funding was mentioned as an obstacles by $49 \%(n=205)$ of those who answered this question (See also Table 4.8). Those who mentioned funding said things such as these: "The Fish and Wildlife Service should be granted more capacity for research and should be funded to do so," "I find it frustrating that we have little base-funding or time to conduct baseline research so that we can make better and more informed management decisions." Staffing was an obstacle mentioned by $11 \%(n=47)$. Some of those remarks included: "The greatest weakness in the refuge system is the lack of biological staff that can spend the time necessary with research to give managers better information with which to make decisions." Another respondent said, "It's tough when you've never even been staffed at your minimum staffing level, and then lose more positions through attrition, to even begin to think about research."

An additional obstacle mentioned was political influences. Nine percent $(n=39)$ of respondents to this question said something about this subject. A typical statement was: "To be very candid, the current political climate does not seem to be conducive to Service scientists coming out with studies that contradict the current administration's policies, or that contradict some special business interest's agenda." The largest number of 
respondents in this grouping remarked upon the subject of credibility. Thirty-five percent $(n=145)$ expressed thoughts about the need for sound science, feelings that the loss of research capability was detrimental to the FWS, and that more research is needed. Respondents we placed in this category made statements such as these:

- Our credibility in the public arena suffers when we are not perceived as experts in our field. We need to maintain active research in order to preserve our credibility and to (slowly) address important management issues. We also need to continue research in order to maintain our creativity in the ways in which we address management issues.

- It is very frustrating for biologists to be judged or required to sustain their ideas and rationale under the concept of "best scientific information available" when research appears not to be a priority for the Field Offices and the biologists are not encouraged or supported to obtain data from research activities about the resources.

- It is my understanding that when the research capabilities of the FWS went to USGS in the mid 1990s, our agency lost considerable conservation opportunities, research flexibility, and departmental respect/integrity.

- This may have actually started when the national biological survey (precursor to BRD) was formed perhaps resulting in an unspoken mindset that Interior's best $\&$ brightest scientists were siphoned off into that new agency. I think it has resulted in an unintended and unfortunate paradigm shift that there are others (outside FWS) that 'do science' and we just apply it.

Fifteen percent $(n=63)$ of respondents remarked upon other subjects. These included the survey instrument itself $(7 \% ; n=27)$. Most of these comments were critical of some aspect of the questionnaire. Personal experience accounted for another $4 \%(n=18)$ of responses, with statements such as "My first position with the service was $100 \%$ research. My current position is largely management and I am trying to incorporate a research component." Finally, a grouping we labeled miscellaneous contained 5\% $(n=19)$ of responses, including statements of this kind: "I feel FWS should continue to foster research opportunities for tribal governments and Native organizations on Refuges while maintaining a lead role, but should absolutely not consider contracting our research efforts to the private sector."

\section{Discussion}

Our findings suggest that research is a key component to working with employees of the FWS, and that issues that cloud the scientific reputation of the FWS are likely to be strong negative motivators.

The purpose of the administration of the scaled-response survey instrument was to ascertain the attitudes and perceptions of employees involved in research regarding the obstacles and opportunities for research at the FWS. The items included on the survey instrument were chosen to address a number of questions about the obstacles and opportunities for research at the FWS. The survey instrument was also intended to assess the nature of research activity in which FWS employees have been engaged recently.

The results of the survey indicated that the majority of the survey respondents (76\%) are involved in some sort of research activity. Additionally, a large percentage of the respondents reported that the majority of their jobs (75\%) involve research. Most of the research in question is applied versus basic in nature; in fact, two of the research activities that respondents reported engaging in most frequently were (1) using data to evaluate management actions, and (2) using data to inform decision-makers. The survey results indicated that FWS employees tend to report the results of their research most frequently at scientific symposia or in publications of the FWS or other government agencies; however, at least $17 \%$ of the survey respondents said that they publish in peerreviewed scientific journals either frequently or always. The responses of the survey participants suggested that FWS employees value scientific research, as the majority of the participants reported that they were likely to be happier with their jobs at the FWS if there were greater research opportunities and unlikely to be happier with their jobs if there were fewer research opportunities.

The survey instrument included items addressing the perceptions of management support for research at the FWS. The respondents generally perceived a lack of management support for research. Their responses to the survey items indicated that there is a perception that there is lack of a clear career path leading to advancement through conducting research at the FWS. Respondents tended to feel that they cannot obtain the financial resources they need to conduct research. Additionally, respondents tended to disagree with the statement that the FWS encourages them to publish research. The respondents' feelings were more neutral on the perception that their supervisors encourage them to publish research and the perception that the FWS encourages them to get involved in research. 
The survey instrument included items addressing satisfaction with working at the FWS in regards to research opportunities and obstacles, as well as respondents' general satisfaction with their current positions at the FWS. The respondents' overall level of satisfaction with their current positions was high with $79 \%$ answering that they were somewhat or completely satisfied with their current positions at the FWS. The survey participants tend to be dissatisfied with the level of financial support they receive for research and with the amount of research time they have, free from other commitments. Participants concern over financial support for research appears to be a reoccurring theme from the survey data.

The data from the survey were used to assess whether known researchers are more likely to engage in "basic" science research activities when compared to survey participants who were not predetermined to be researchers. Testing hypotheses, designing research methods, writing research project proposals, and writing reports of research results were considered basic science activities for the purpose of this study. For all of these basic science activities, the percentage of respondents who reported engaging in the research activities was larger for the group of participants who were known researchers than for participants who were not predetermined to be known researchers.

The findings from the survey indicate that known researchers were more likely to report that a larger percentage of their jobs involve research than the group of participants who were not predetermined to be researchers. Additionally, the data suggest that all but one of the research activities listed on the survey (See Table 1 ), were associated with reporting that a large percentage of one's job involves research. The only activity that this relationship did not hold true for was supervising or coordinating the efforts of other FWS employees who are engaged in research activity. Finally, the findings drawn from the survey indicate that respondents who felt encouraged to conduct research, by either their supervisors or by the FWS, were more satisfied with their jobs and with various aspects of their jobs related to research. 


\section{Chapter 5}

\section{Conclusions}

It is vitally important for FWS employees to be known as experts in the fields of fish and wildlife conservation. It is also important for the FWS to have ready access to research-based information that can help inform decision-making. Although the FWS can and does contract out for a great many studies, promoting an internal culture to support and encourage in-house research activities remains an important consideration. In commissioning this research, the Directorate of the FWS recognized that it would be to the advantage of the agency to more fully understand its own research capacity.

To develop a clearer picture of the nature, extent, quality, and degree of management support available for conducting research within the FWS, we completed investigations to:

1. identify organizational units within the FWS that may conduct research as a significant portion of their unit mission;

2. identify positions in the FWS that may include, in whole or in part, a component of scientific research; and

3. assess the attitudes of employees and managers about the obstacles and opportunities for scientific research existing within the FWS.

We conclude that the FWS does possess some capacity to conduct research, and that the agency has been measurably successful in doing so as part of its own programs and with its own employees. Although most of the research work done in the FWS does not directly involve testing formal, explicitly stated hypotheses, the agency is engaged in the formal gathering and systematic analysis of data.

As evidence for this finding we point to the 1,355 articles published by 496 different employees who were employed by the FWS in professional series positions over the period 1995-2004. These employees represent 275 units located across the country that were involved in a wide variety of scientific activities. Given the obstacles to conducting research that were reported by FWS employees, it is impressive that 1 out of $9(11 \%)$ of professional series employees had published during the nine-year span we investigated. A high proportion of this publication activity can be accounted for in Wildlife Refuges and Fish Hatcheries (34\%).

However, the public face of the FWS does not reflect the intensity or diversity of this research activity. Our review of public documents suggests that because the agency does not consistently underscore its science commitment, it is difficult to develop a sense that science is an important part of the FWS's management philosophy. An inescapable fact is that a person reviewing web pages or fact sheets would have a very different impression of the research capacity of the FWS, depending on which of these documents was examined. This might be described as an inconsistency in how the FWS portrays itself, perhaps due to the lack of a formal policy regarding presentation of research activities.

That inconsistency was evident in our discussions with regional personnel managers. Many of them expressed surprise to learn that any positions in their region were classified as function code 11 (meaning involved in research). When we pressed the personnel officers to verify the accuracy of these classifications they judged the majority of these classifications to be inaccurate in every FWS region. One thing the personnel officers agreed about is that there is no policy about using the Research Grade Evaluation Guide (RGEG) to classify FWS personnel.

In fact, the personnel officers were skeptical that researchers could be identified through either review of position descriptions or the examination of the official personnel databases. Although $62 \%$ of respondents to our survey thought their individual position descriptions were accurate, the personnel officers were basically correct about issues of standardization and accuracy of position descriptions. The manner in which the research characteristics of position descriptions are written varies considerably across regions.

When we looked simply at the presence/absence, frequency, or sum of keywords related to research and compared position descriptions to publication status, we could identify some keywords that distinguish between people who have published from those who have not published. However, this was only true for some regions. 
Moreover, the keywords that distinguish between publishers and non-publishers differ from region to region. On one hand, evaluation of the surface level content of the position descriptions (i.e., keywords) is likely to be an unreliable method for identifying positions involved in conducting research. On the other hand, a catalog of keywords suitable for use in preparing research-oriented position descriptions might be helpful in closing this gap.

We know from the data on number of publications, number of organizational units conducting research, number of people who have published, and ratio of publishers to non-publishers, that FWS employees are capable of conducting research. When we examined position descriptions beyond mere keywords we found that the most frequent categories of capability were knowledge, skill, and ability for research methods and data analysis; the next most frequently mentioned category was application of research information to management actions. These two categories were followed by additional research-related categories such as designing studies and collecting data, which suggests that the FWS may wish to focus on enhancing employee skills to either perform these tasks or work effectively with those who do. It is encouraging to note that the majority of position descriptions containing research language were concentrated at GS grades 11, 12, and 13. Because of the importance of encouraging a science culture in the FWS, it might be quite advantageous to rework position descriptions systematically across the agency so that the research component is directly evident.

If the FWS looks a bit inconsistent about its research capacity as seen through the eyes of its public documents and personnel records, how does it appear to its own employees? If we were to judge from the answers given to the open-ended questions on our survey instrument, the answer is that many employees are concerned about the FWS's reputation for science and want to see that reputation enhanced. Fifty-two percent of those who answered the final open-ended question addressed this general issue. It is certainly evident from those responses that there is a group of employees who are somewhat cynical in their attitudes about whether or not the FWS can become the strong research-based organization they wish it were.

We designed the survey to answer several questions: (1) What is the nature of current research assignments in the FWS? (2) What resources are available for research studies? (3) How are research results reported? (4) How are research products used by managers? and (5) what are the obstacles and opportunities for conducting research? First, we examined the nature of the research and found that employees report participating in a wide range of research-related activities. The majority of this sample of FWS employees reported that they engage in some sort of research activity. Almost 54\% said they analyze data, more than half (52\%) collect and use data to inform managers or decision-makers, and a majority (51\%) collect and use data to evaluate particular management actions. It is interesting to note that $38 \%$ of respondents said that at least three-quarters of their job involve conducting research. The research in which employees are involved includes almost half working in fish and wildlife ecology, habitat or behavior, $19 \%$ in monitoring, and about $9 \%$ in contaminants. In short, there is a sizeable group within the agency that understands itself to be part of a research community, research assignments appear to be rather practical in nature, and studies focus on issues of direct practical concern to the FWS.

Second, what resources are available for research studies? Overall, the results indicate that the majority of survey respondents disagreed that there is adequate management support for research at the FWS. Feelings of lack of support were expressed most strongly on measures of career opportunities ("There is a clear career path leading to advancement for me through conducting research' [mean $=2.12]$ ) and obtaining "financial resources that are necessary to conduct research from FWS funds" (mean $=2.21)$. Survey respondents were nearly neutral about management support in the form of supervisory (mean $=2.97)$ and agency encouragement $($ mean $=3.05)$ to be involved in research.

Third, how are research results reported? We found more than 1,300 publications from FWS employees, and respondents reported that they publish only infrequently in the peer reviewed literature. The most frequent methods for reporting research results were through symposia or conferences, or in the publications of other government agencies. These types of publications would not have been discoverable through a search of the Web of Science.

Fourth, how are research products used by managers? Managers who answered our survey instrument indicated that almost $85 \%(n=312)$ use the results of others' research studies in the course of their work (Neilson and others, 2005). In a question that asked respondents to prioritize their sources of information, an average of $25 \%$ $(n=235)$ reported that they relied on scientific journals. A similar average percentage relied on "colleagues within the FWS" $(23 \% ; n=270)$. Conferences $(13 \% ; n=208)$, the Internet $(18 \% ; n=204)$, personal contacts $(16 \% ; n=$ $216)$, colleagues in other agencies $(18 \% ; n=257)$ and reports of other agencies $(16 \% ; n=211)$ made up other items on the priority list. Open media sources such as newspapers and TV received the lowest average ranking at $7 \%(n=$ 119) (Neilson and others, 2005). 
Fifth, what are the obstacles and opportunities for conducting research? Respondents rated finances and availability of time as important limits on their ability to conduct research. To learn more about the impediments to research, we asked the question: "Is there any other information you would like to provide regarding the support, lack of support, obstacles, inducements, or resources at the FWS with regard to research?" A total of 415 respondents answered this question, which was available only to those who classified themselves as involved in research. We condensed the open-ended answers, resulting in $74 \%(n=308)$ who remarked upon obstacles to conducting research. Of these $30 \%(n=123)$ mentioned time availability.

Finally, we examined the value of science to FWS employees and employee satisfaction. Few told us they were planning to leave the FWS. Rather, employees indicated a high value for science. By and large, they came into the FWS expecting to do some research and would feel more satisfied if their current positions included more research and science-based activities. Overall, respondents tend to be somewhat satisfied with their current positions in the FWS, nearly neutral about the level of encouragement to do research they receive from supervisors, and neutral about the weight given to research as part of their individual performance evaluations. Respondents expressed far less satisfaction with the level of financial support they receive for research and with the amount of time they have to do research.

\section{Acknowledgments}

We are thankful for the assistance of Brian S. Cade, Cynthia Melcher, Kimberly J. Morgan, M. Earlene Swann, Jonathan G. Taylor, and Katherine D. Wundrock in the completion of this report. The findings and conclusions expressed in this paper are those of the authors and do not necessarily reflect the policies of the U.S. Geological Survey, U.S. Fish and Wildlife Service, or Department of the Interior.

\section{References Cited}

Busch, C., De Maret, P.S., Flynn, T., Kellum, R., Meyers, S.L.B., Saunders, M., White, R., and Palmquist, M., 2005, Content analysis. Fort Collins, Colorado: Colorado State University Department of English. Retrieved [May 4, 2005] from http://writing.colostate.edu/references/research/content/.

Cohn, J.P., 2005, After the divorce: Improving science at federal wildlife agencies: Bioscience, v. 55, no. 1, p. 1-14.

Dillman, D.A., 2000, Mail and internet surveys: The tailored design method, (2nd ed.): New York: John Wiley \& Sons, Inc.

Hays, W.L. (1988). Statistics, (4th ed.): Holt, Rinehart and Winston, Fort Worth, Texas.

Lamb, B.L., Burkardt, N., Gillette S.C., and Taylor, J., 2001, Briefing on the case study analysis of the North Umpqua hydropower relicensing negotiations: report to the United States Forest Service: Administrative Report, Fort Collins, Colorado: U.S. Geological Survey (available from the authors).

Murphy, K.R., and Myors, B., 1998, Statistical power analysis: A simple and general model for traditional and modern hypothesis tests: Mahwah, New Jersey, Lawrence Erlbaum Associates.

Neilson, J.R., Lamb, B.L., Swann, E.M., Ratz, J., Ponds, P.D., and Liverca, J., 2005, Attitudinal survey component of the study quantity, quality, and support for research in the U.S. Fish and Wildlife Service: An organizational assessment: Report of methods and frequencies: Administrative Report. Fort Collins, Colorado: U.S. Geological Survey (available from the authors).

Riffe, D., Lacy, S., and Fico, F.G., 1998, Analyzing media messages: Using quantitative content analysis in research: Mahwah, New Jersey, Lawrence Erlbaum Associates.

Robinson, S.L., 1995, Violation of psychological contracts: Impact on employee attitudes, in Tetrick, L. E. and Barling, J. eds., Changing employment relations: Behavioral and social perspectives. Washington, D.C; American Psychological Association, p. 91-108.

Weber, R.P., 1990, Basic content analysis, (2nd ed.) Sage Publications: Newbury Park, California. 


\section{Appendix 2A. Organizational Units that Conduct Research}

\begin{tabular}{|c|c|c|c|c|}
\hline Region & $\begin{array}{l}\text { Published } \\
\text { Authors }\end{array}$ & Org Unit & Website & Notes \\
\hline 9 & 3 & $\begin{array}{l}\text { Aquatic Animal Drug Appr. } \\
\text { Partnership }\end{array}$ & & \\
\hline 9 & 2 & $\begin{array}{l}\text { Division of Bird Habitat } \\
\text { Initiatives }\end{array}$ & & \\
\hline 9 & 2 & $\begin{array}{l}\text { Division of Environmental } \\
\text { Quality }\end{array}$ & & \\
\hline 9 & 2 & $\begin{array}{l}\text { Division of Fish and Wildlife } \\
\text { Management and Habitat } \\
\text { Restoration }\end{array}$ & & \\
\hline 9 & 26 & $\begin{array}{l}\text { Division of Migratory Bird } \\
\text { Management }\end{array}$ & http://migratorybirds.fws.gov & $\begin{array}{l}\text { Research Links point to } \\
\text { Patuxent Wildlife Research } \\
\text { Center's web page and } \\
\text { "monitoring efforts" }\end{array}$ \\
\hline 9 & 4 & Division of Natural Resources & & \\
\hline 9 & 1 & $\begin{array}{l}\text { Division of the National Fish } \\
\text { Hatchery System }\end{array}$ & & \\
\hline 9 & 1 & $\begin{array}{l}\text { Division of Environmental } \\
\text { Quality }\end{array}$ & & \\
\hline 9 & 1 & ECON & & \\
\hline 9 & 4 & $\begin{array}{l}\text { National Conservation Training } \\
\text { Center }\end{array}$ & & \\
\hline 9 & 4 & National Forensic Laboratory & & \\
\hline 9 & 1 & $\begin{array}{l}\text { National Wetlands Inventory } \\
\text { Center }\end{array}$ & & $\begin{array}{l}\text { Wetlands Mapper - Meta data } \\
\text { (in cooperation with the } \\
\text { National Map and USGS) }\end{array}$ \\
\hline 9 & 1 & National Wildlife Refuges & & \\
\hline 9 & 2 & $\begin{array}{l}\text { Office of Conservation and } \\
\text { Classification }\end{array}$ & & \\
\hline 9 & 1 & $\begin{array}{l}\text { Patuxent Analytical Control } \\
\text { Facility }\end{array}$ & & \\
\hline 14 & 55 & 55 & & \\
\hline 7 & 5 & $\begin{array}{l}\text { Alaska Maritime National } \\
\text { Wildlife Refuge }\end{array}$ & $\begin{array}{l}\text { http://alaska.fws.gov/nwr/akma } \\
\text { r/index.htm }\end{array}$ & $\begin{array}{l}\text { In the } 1980 \text { establishing act } \\
\text { forming the Alaska Maritime } \\
\text { National Wildlife Refuge, the } \\
\text { U.S. Congress mandated that } \\
\text { this refuge conduct national } \\
\text { and international scientific } \\
\text { research on marine resources - } \\
\text { We use information from } \\
\text { inventorying and monitoring } \\
\text { to pose questions such as } \\
\text { "what is causing an observed } \\
\text { change?" Thus, we can direct } \\
\text { our research and special } \\
\text { studies to learn more about } \\
\text { marine and island ecosystem } \\
\text { processes, the interaction } \\
\text { among species, and the } \\
\text { ecology of little-known } \\
\text { species that are found only } \\
\text { here (endemics). }\end{array}$ \\
\hline
\end{tabular}




\begin{tabular}{|c|c|c|c|c|}
\hline Region & $\begin{array}{l}\text { Published } \\
\text { Authors }\end{array}$ & Org Unit & Website & Notes \\
\hline 7 & 1 & $\begin{array}{l}\text { Alaska Migratory Bird Co- } \\
\text { Management }\end{array}$ & & \\
\hline 7 & 4 & $\begin{array}{l}\text { Arctic National Wildlife } \\
\text { Refuge }\end{array}$ & $\begin{array}{l}\text { http://alaska.fws.gov/nwr/arctic } \\
\text { /index.htm }\end{array}$ & $\begin{array}{l}\text { Partial bibliography of } \\
\text { scientific research conducted } \\
\text { on the Refuge by U.S. Fish } \\
\text { and Wildlife Service } \\
\text { biologists and others }\end{array}$ \\
\hline 7 & 5 & Conservation Genetics Lab & & $\begin{array}{l}\text { various projects representing } \\
\text { "first steps" toward genetic } \\
\text { identification }\end{array}$ \\
\hline 7 & 4 & $\begin{array}{l}\text { Division of Fisheries and } \\
\text { Habitat Conservation }\end{array}$ & & $\begin{array}{l}\text { From "science" web page: } \\
\text { "Science is the foundation for } \\
\text { the work of the Service, In our } \\
\text { commitment to quality } \\
\text { science, we strive to ask the } \\
\text { right questions, base our work } \\
\text { on accepted scientific } \\
\text { principles, and seek } \\
\text { independent peer review, and } \\
\text { publish our results. }\end{array}$ \\
\hline 7 & 6 & $\begin{array}{l}\text { Division of Marine Mammals } \\
\text { Management }\end{array}$ & & "research" publication listing \\
\hline 7 & 8 & $\begin{array}{l}\text { Division of Migratory Birds } \\
\text { Management }\end{array}$ & & $\begin{array}{l}\text { identify "monitor," "determine } \\
\text { effects," "obtain information } \\
\text { from subsistence harvesting } \\
\text { by Alaska Natives" }\end{array}$ \\
\hline 7 & 2 & Division of Natural Resources & & \\
\hline 7 & 1 & $\begin{array}{l}\text { Division of Visitor Services } \\
\text { and Communications }\end{array}$ & & \\
\hline 7 & 4 & $\begin{array}{l}\text { Fish and Wildlife Field Office } \\
\text { Anchorage, AK }\end{array}$ & & $\begin{array}{l}\text { The scientific activities we } \\
\text { conduct are diverse, ranging } \\
\text { from basic inventories of fish } \\
\text { and wildlife species on remote } \\
\text { National Wildlife Refuge } \\
\text { lands, to population } \\
\text { monitoring of select wildlife } \\
\text { species, to applied research to } \\
\text { help us make management } \\
\text { decisions. }\end{array}$ \\
\hline 7 & 1 & $\begin{array}{l}\text { Fish and Wildlife Field Office } \\
\text { Fairbanks, AK }\end{array}$ & & $\begin{array}{l}\text { Radio telemetry is one } \\
\text { example of research methods } \\
\text { that yield new information } \\
\text { about species that will be used } \\
\text { for more effective } \\
\text { management of the population } \\
\text { and its habitats. }\end{array}$ \\
\hline 7 & 4 & $\begin{array}{l}\text { Fish and Wildlife Field Office } \\
\text { Fairbanks, AK }\end{array}$ & & \\
\hline 7 & 2 & $\begin{array}{l}\text { Fish and Wildlife Field Office } \\
\text { Juneau, AK }\end{array}$ & & \\
\hline 7 & 2 & $\begin{array}{l}\text { Kenai National Wildlife } \\
\text { Refuge }\end{array}$ & $\begin{array}{l}\text { http://alaska.fws.gov/nwr/kenai } \\
\text { /index.htm }\end{array}$ & $\begin{array}{l}\text { Refuge purpose: (iv) to } \\
\text { provide opportunities for } \\
\text { research, interpretations, } \\
\text { environmental education, and } \\
\text { land management training; }\end{array}$ \\
\hline
\end{tabular}




\begin{tabular}{|c|c|c|c|c|}
\hline Region & $\begin{array}{l}\text { Published } \\
\text { Authors }\end{array}$ & Org Unit & Website & Notes \\
\hline 7 & 1 & $\begin{array}{l}\text { Kodiak National Wildlife } \\
\text { Refuge }\end{array}$ & $\begin{array}{l}\text { http://alaska.fws.gov/nwr/kodia } \\
\text { k/index.htm }\end{array}$ & $\begin{array}{l}\text { The Refuge also sponsors and } \\
\text { conducts basic and applied } \\
\text { research projects, develop } \\
\text { monitoring methods, and } \\
\text { evaluate management } \\
\text { strategies. }\end{array}$ \\
\hline 7 & 1 & $\begin{array}{l}\text { Koyukuk/ Nowitna National } \\
\text { Wildlife Refuge }\end{array}$ & $\begin{array}{l}\text { http://alaska.fws.gov/nwr/koyu } \\
\text { kuk/index.htm }\end{array}$ & \\
\hline 7 & 5 & $\begin{array}{l}\text { Non-game Migratory Bird } \\
\text { Management }\end{array}$ & & \\
\hline 7 & 1 & Office of the Regional Director & & $\begin{array}{l}\text { Science is the backbone of the } \\
\text { Fish and Wildlife Service. } \\
\text { Quality scientific projects are } \\
\text { the underpinning of good } \\
\text { management and decision- } \\
\text { making. Fish and Wildlife } \\
\text { Service employees in the } \\
\text { various programs and field } \\
\text { offices in Alaska are engaged } \\
\text { in a wide variety of scientific } \\
\text { projects to meet our } \\
\text { stewardship and conservation } \\
\text { missions. }\end{array}$ \\
\hline 7 & 1 & $\begin{array}{l}\text { Selawik National Wildlife } \\
\text { Refuge }\end{array}$ & $\begin{array}{l}\text { http://alaska.fws.gov/nwr/selaw } \\
\text { ik/index.htm }\end{array}$ & Biological projects \\
\hline 7 & 1 & $\begin{array}{l}\text { Tetlin National Wildlife } \\
\text { Refuge }\end{array}$ & $\begin{array}{l}\text { http://alaska.fws.gov/nwr/tetlin/ } \\
\text { index.htm }\end{array}$ & Biological projects \\
\hline 7 & 4 & $\begin{array}{l}\text { Yukon Delta National Wildlife } \\
\text { Refuge }\end{array}$ & $\begin{array}{l}\text { http://alaska.fws.gov/nwr/yuko } \\
\text { ndelta/index.htm }\end{array}$ & \\
\hline 22 & 63 & 64 & 8 & \\
\hline 6 & 1 & Bozeman Fish Health Center & $\begin{array}{l}\text { http://bozemanfishhealth.fws.g } \\
\text { ov/ or } \\
\text { http://fisheries.fws.gov/FTC/FT } \\
\text { Cbzmn.htm }\end{array}$ & $\begin{array}{l}\text { The Center maintains } \\
\text { expertise in several laboratory } \\
\text { disciplines: virology, } \\
\text { bacteriology, parasitology, } \\
\text { histology, epidemiology, } \\
\text { pathology, and molecular } \\
\text { biology. }\end{array}$ \\
\hline 6 & 1 & $\begin{array}{l}\text { Bozeman Fish Technology } \\
\text { Center }\end{array}$ & $\begin{array}{l}\text { http://bozemanfishtech. } \\
\text { fws.gov/ }\end{array}$ & $\begin{array}{l}\text { "The Center maintains } \\
\text { expertise in several laboratory } \\
\text { disciplines: virology, } \\
\text { bacteriology, parasitology, } \\
\text { histology, epidemiology, } \\
\text { pathology, and molecular } \\
\text { biology." }\end{array}$ \\
\hline 6 & 1 & $\begin{array}{l}\text { C M Russel National Wildlife } \\
\text { Refuge }\end{array}$ & http://cmr.fws.gov/ & \\
\hline 6 & 2 & $\begin{array}{l}\text { Colorado Fish and Wildlife } \\
\text { Management Assistance Office }\end{array}$ & $\begin{array}{l}\text { http://www.r6.fws.gov/fisheries } \\
\text { /co/colorado_fwmao.htm }\end{array}$ & \\
\hline 6 & 3 & $\begin{array}{l}\text { Colorado River Fishery Project } \\
\text { Grand Junction, CO }\end{array}$ & $\begin{array}{l}\text { http://grandjunctionfishandwild } \\
\text { life.fws.gov/) }\end{array}$ & \\
\hline
\end{tabular}




\begin{tabular}{|c|c|c|c|c|}
\hline Region & $\begin{array}{l}\text { Published } \\
\text { Authors }\end{array}$ & Org Unit & Website & Notes \\
\hline 6 & 2 & $\begin{array}{l}\text { Colorado River Fishery Project } \\
\text { Vernal, UT }\end{array}$ & $\begin{array}{l}\text { http://vernalfishandwildlife.fws } \\
\text { gov/ }\end{array}$ & $\begin{array}{l}\text { Project activities include } \\
\text { basin-wide monitoring } \\
\text { programs for the endangered } \\
\text { fishes and their habitats, } \\
\text { management-oriented research } \\
\text { activities, instream flow } \\
\text { assessments and } \\
\text { recommendations, database } \\
\text { management and data } \\
\text { analyses, and experimental } \\
\text { population augmentation and } \\
\text { restoration programs }\end{array}$ \\
\hline 6 & 2 & $\begin{array}{l}\text { Des Lacs National Wildlife } \\
\text { Refuge }\end{array}$ & $\begin{array}{l}\text { http://mountain- } \\
\text { prairie.fws.gov/dslcomplex/desl } \\
\text { acs.htm OR } \\
\text { http://deslacs.fws.gov/dsl.htm }\end{array}$ & \\
\hline 6 & 1 & $\begin{array}{l}\text { Division of Bird Habitat } \\
\text { Conservation Initiatives }\end{array}$ & & \\
\hline 6 & 1 & Division of Federal Aid & & \\
\hline 6 & 4 & Division of Migratory Birds & & \\
\hline 6 & 5 & $\begin{array}{l}\text { Ecological Services Field } \\
\text { Office Cheyenne, WY }\end{array}$ & & \\
\hline 6 & 1 & $\begin{array}{l}\text { Ecological Services Field } \\
\text { Office Grand Junction, CO }\end{array}$ & & \\
\hline 6 & 5 & $\begin{array}{l}\text { Ecological Services Field } \\
\text { Office Helena, MT }\end{array}$ & http://montanafieldoffice.fws.gov/ & \\
\hline 6 & 2 & $\begin{array}{l}\text { Ecological Services Field } \\
\text { Office Pierre, SD }\end{array}$ & & \\
\hline 6 & 2 & $\begin{array}{l}\text { Ecological Services Field } \\
\text { Office Salt Lake City, UT }\end{array}$ & & \\
\hline 6 & 1 & Ennis National Fish Hatchery & http://ennis.fws.gov/ & \\
\hline 6 & 1 & $\begin{array}{l}\text { Ft. Niobrara National Wildlife } \\
\text { Refuge }\end{array}$ & http://fortniobrara.fws.gov/ & \\
\hline 6 & 1 & $\begin{array}{l}\text { Gavins Point National Fish } \\
\text { Hatchery }\end{array}$ & http://gavinspoint.fws.gov/ & \\
\hline 6 & 1 & $\begin{array}{l}\text { Great Plains Fish and Wildlife } \\
\text { Management Assistance Office }\end{array}$ & $\begin{array}{l}\text { http://mountain- } \\
\text { prairie.fws.gov/greatplains/resp } \\
\text { onsibilities.html }\end{array}$ & $\begin{array}{l}\text { Conducting research and } \\
\text { management activities leading } \\
\text { to the recovery of Federally } \\
\text { listed threatened and } \\
\text { endangered species such as } \\
\text { pallid sturgeon. }\end{array}$ \\
\hline 6 & 2 & Grizzly Bear Recovery Office & $\begin{array}{l}\text { http://mountain- } \\
\text { prairie.fws.gov/species/mamma } \\
\text { ls/grizzly/ }\end{array}$ & \\
\hline 6 & 4 & $\begin{array}{l}\text { Habitat and Population } \\
\text { Evaluation Team, Bismarck }\end{array}$ & & \\
\hline 6 & 1 & $\begin{array}{l}\text { J. Clark Salyer National } \\
\text { Wildlife Refuge }\end{array}$ & http://jclarksalyer.fws.gov/ & \\
\hline 6 & 4 & Kansas Field Office & & \\
\hline 6 & 1 & $\begin{array}{l}\text { Kulm Waterfowl Management } \\
\text { District }\end{array}$ & http://kulmwetlands.fws.gov/ & \\
\hline 6 & 1 & $\begin{array}{l}\text { Lostwood National Wildlife } \\
\text { Refuge }\end{array}$ & http://lostwood.fws.gov/ & \\
\hline 6 & 1 & $\begin{array}{l}\text { Medicine Lake National } \\
\text { Wildlife Refuge }\end{array}$ & http://medicinelake.fws.gov/ & White Pelican research \\
\hline
\end{tabular}




\begin{tabular}{|c|c|c|c|c|}
\hline Region & $\begin{array}{l}\text { Published } \\
\text { Authors }\end{array}$ & Org Unit & Website & Notes \\
\hline 6 & 1 & $\begin{array}{l}\text { Missouri River Coordinator } \\
\text { Office }\end{array}$ & & \\
\hline 6 & 1 & $\begin{array}{l}\text { Missouri River Fish and } \\
\text { Wildlife Management } \\
\text { Assistance Office }\end{array}$ & $\begin{array}{l}\text { http://missouririverfishandwildl } \\
\text { ife.fws.gov/ }\end{array}$ & \\
\hline 6 & 1 & Montana FWMAO & & $\begin{array}{l}\text { We conduct detailed } \\
\text { investigations of fish } \\
\text { entrainment in the Saint Mary } \\
\text { Canal. These studies are } \\
\text { aimed at estimating the } \\
\text { density, species composition, } \\
\text { and timing (diel and seasonal) } \\
\text { of fish entrained in the canal } \\
\text { and determining the efficacy } \\
\text { of an electric fish barrier } \\
\text { installed at the canal } \\
\text { headgates. Entrainment nets } \\
\text { installed on the headgates are } \\
\text { operated periodically during } \\
\text { the irrigation season (April- } \\
\text { September). At the end of the } \\
\text { season, after the canal } \\
\text { headgates are closed and the } \\
\text { canal is drained, netting } \\
\text { surveys are also conducted in } \\
\text { isolated canal pools. Native } \\
\text { fish that are encountered are } \\
\text { released back into the St. } \\
\text { Mary River. }\end{array}$ \\
\hline 6 & 1 & $\begin{array}{l}\text { Montana Native Fish } \\
\text { Coordinator }\end{array}$ & & \\
\hline 6 & 1 & $\begin{array}{l}\text { National Black-Footed Ferret } \\
\text { Conservation Center }\end{array}$ & $\begin{array}{l}\text { http://southdakotafieldoffice.fw } \\
\text { s.gov/FERRET.HTM }\end{array}$ & \\
\hline 6 & 1 & National Elk Refuge & http://nationalelkrefuge.fws.gov & $\begin{array}{l}\text { http://nationalelkrefuge.fws.g } \\
\text { ov/NERResearch\&Science.ht } \\
\text { ml }\end{array}$ \\
\hline 6 & 1 & Ouray National Fish Hatchery & http://ourayhatchery.fws.gov/ & \\
\hline 6 & 1 & $\begin{array}{l}\text { Rainwater Basin Wetland } \\
\text { Management District }\end{array}$ & & \\
\hline 6 & 1 & $\begin{array}{l}\text { RO National Wildlife Refuge } \\
\text { Systems }\end{array}$ & & \\
\hline 6 & 1 & $\begin{array}{l}\text { Rocky Mountain Arsenal } \\
\text { National Wildlife Refuge }\end{array}$ & http://rockymountainarsenal.fws.gov & $\begin{array}{l}\text { Beginning this spring, } \\
\text { biologists at RMA will be } \\
\text { trapping and darting Mule and } \\
\text { White-tailed Deer as part of } \\
\text { an on-going study to } \\
\text { determine why the deer herds } \\
\text { are producing fewer fawns. }\end{array}$ \\
\hline 6 & 1 & $\begin{array}{l}\text { Roosevelt Fish and Wildlife } \\
\text { Management Assistance } \\
\text { Office, UT }\end{array}$ & & \\
\hline 6 & 1 & $\begin{array}{l}\text { South Dakota Partners for Fish } \\
\text { and Wildlife }\end{array}$ & & \\
\hline
\end{tabular}




\begin{tabular}{|c|c|c|c|c|}
\hline Region & $\begin{array}{l}\text { Published } \\
\text { Authors }\end{array}$ & Org Unit & Website & Notes \\
\hline 6 & 2 & $\begin{array}{l}\text { Upper Colorado River } \\
\text { Endangered Fish Recovery } \\
\text { Program }\end{array}$ & http://coloradoriverrecovery.fws.gov & $\begin{array}{l}\text { In 1979, the U. S. Fish and } \\
\text { Wildlife Service's Colorado } \\
\text { River Fisheries Project began } \\
\text { coordinating research on } \\
\text { endangered fish. These early } \\
\text { research projects provided } \\
\text { background information } \\
\text { necessary to guide current } \\
\text { research studies. } \\
\text { (http://coloradoriverrecovery.f } \\
\text { ws.gov/Crrpres.) }\end{array}$ \\
\hline 6 & 1 & $\begin{array}{l}\text { Valley City National Fish } \\
\text { Hatchery }\end{array}$ & http://valleycity.fws.gov/ & \\
\hline 40 & 66 & 64 & 24 & \\
\hline 5 & 2 & ARD Ecological Services & $\begin{array}{l}\text { http://northeast.fws.gov/ecologi } \\
\text { calservices/ }\end{array}$ & \\
\hline 5 & 3 & ARD Fisheries & & \\
\hline 5 & 1 & $\begin{array}{l}\text { Canaan Valley National } \\
\text { Wildlife Refuge }\end{array}$ & & \\
\hline 5 & 4 & Chesapeake Bay Field Office & http://www.fws.gov/chesapeakebay & \\
\hline 5 & 2 & Division of Federal Aid & http://www.fws.gov/r5fedaid/ & \\
\hline 5 & 1 & Division of Migratory Birds & & \\
\hline 5 & 1 & $\begin{array}{l}\text { Eastern Shore of Virginia } \\
\text { National Wildlife Refuge }\end{array}$ & & \\
\hline 5 & 1 & Gulf of Maine Project & & \\
\hline 5 & 1 & Connecticut River Coord. & & \\
\hline 5 & 8 & FR Lamar Fish Tech Center & $\begin{array}{l}\text { http://northeast.fws.gov/fishery } \\
\text { center/ }\end{array}$ & $\begin{array}{l}\text { Assists in the development of } \\
\text { management strategies } \\
\text { through assessment and } \\
\text { applied research to support the } \\
\text { protection of wild stocks and } \\
\text { recovery of threatened and } \\
\text { endangered species. }\end{array}$ \\
\hline 5 & 1 & $\begin{array}{l}\text { FR Lower Great Lakes Fishery } \\
\text { Resource Office }\end{array}$ & & \\
\hline 5 & 1 & $\begin{array}{l}\text { Great Dismal Swamp National } \\
\text { Wildlife Refuge }\end{array}$ & & \\
\hline 5 & 1 & Gulf of Maine Coastal Program & & \\
\hline 5 & 3 & $\begin{array}{l}\text { Lake Champlain Fish and } \\
\text { Wildlife Resource Office }\end{array}$ & & \\
\hline 5 & 1 & $\begin{array}{l}\text { Long Island National Wildlife } \\
\text { Refuge Complex }\end{array}$ & & \\
\hline 5 & 2 & $\begin{array}{l}\text { Lower Great Lakes Fishery } \\
\text { Resource Office }\end{array}$ & & $\begin{array}{l}\text { The LGLFRO coordinates the } \\
\text { Northeast Region ANS } \\
\text { Program, which includes four } \\
\text { components: monitoring, } \\
\text { research, education, and } \\
\text { technical assistance and } \\
\text { coordination. }\end{array}$ \\
\hline 5 & 2 & $\begin{array}{l}\text { Maine Ecological Services } \\
\text { Field Office }\end{array}$ & & \\
\hline 5 & 1 & $\begin{array}{l}\text { Maine Fisheries Program } \\
\text { Complex }\end{array}$ & & \\
\hline 5 & 2 & $\begin{array}{l}\text { Maryland Fishery Resource } \\
\text { Office }\end{array}$ & & \\
\hline
\end{tabular}




\begin{tabular}{|c|c|c|c|c|}
\hline Region & $\begin{array}{l}\text { Published } \\
\text { Authors }\end{array}$ & Org Unit & Website & Notes \\
\hline 5 & 4 & New England Field Office & & \\
\hline 5 & 2 & New Jersey Field Office & & \\
\hline 5 & 2 & New York Field Office & & \\
\hline 5 & 1 & $\begin{array}{l}\text { Ohio River Islands National } \\
\text { Wildlife Refuge }\end{array}$ & & \\
\hline 5 & 1 & Pennsylvania Field Office & & \\
\hline 5 & 1 & $\begin{array}{l}\text { Pittsford National Fish } \\
\text { Hatchery }\end{array}$ & & \\
\hline 5 & 1 & $\begin{array}{l}\text { Potomac River National } \\
\text { Wildlife Refuge }\end{array}$ & & \\
\hline 5 & 3 & $\begin{array}{l}\text { Prime Hook National Wildlife } \\
\text { Refuge }\end{array}$ & & \\
\hline 5 & 1 & $\begin{array}{l}\text { R. Cronin National Salmon } \\
\text { Station }\end{array}$ & & \\
\hline 5 & 1 & Regional Biologist-North & & \\
\hline 5 & 1 & RO - ES & & \\
\hline 5 & 1 & $\begin{array}{l}\text { Blackwater National Wildlife } \\
\text { Refuge }\end{array}$ & & \\
\hline 5 & 1 & $\begin{array}{l}\text { Susquehanna River } \\
\text { Coordinator }\end{array}$ & & \\
\hline 5 & 2 & Virginia Field Office & & \\
\hline 5 & 1 & $\begin{array}{l}\text { Virginia Fisheries Coordinator } \\
\text { Office }\end{array}$ & & \\
\hline 34 & 61 & & & \\
\hline 4 & 2 & $\begin{array}{l}\text { Alligator River National } \\
\text { Wildlife Refuge }\end{array}$ & http://alligatorriver.fws.gov/ & $\begin{array}{l}\text { The Refuge encourages } \\
\text { outside entities to propose } \\
\text { wildlife research projects on } \\
\text { Refuge lands. Selected } \\
\text { projects must benefit the } \\
\text { Refuge, as well as provide } \\
\text { needed information on } \\
\text { wildlife populations or } \\
\text { habitats. }\end{array}$ \\
\hline 4 & 1 & ARD Ecological Services & http://www.fws.gov/southeast/es/ & \\
\hline 4 & 1 & $\begin{array}{l}\text { Bear's Bluff National Fish } \\
\text { Hatchery }\end{array}$ & & \\
\hline 4 & 1 & $\begin{array}{l}\text { Cat Island National Wildlife } \\
\text { Refuge }\end{array}$ & $\begin{array}{l}\text { http://www.fws.gov/southeast/c } \\
\text { atisland/index.html }\end{array}$ & \\
\hline 4 & 1 & Division of Migratory Birds & & \\
\hline 4 & 1 & $\begin{array}{l}\text { Ecological Services Ashville, } \\
\text { NC }\end{array}$ & & \\
\hline 4 & 3 & $\begin{array}{l}\text { Ecological Services Boqueron, } \\
\text { PR }\end{array}$ & & \\
\hline 4 & 2 & $\begin{array}{l}\text { Ecological Services Charlston, } \\
\text { SC }\end{array}$ & & \\
\hline 4 & 1 & $\begin{array}{l}\text { Ecological Services Clemson, } \\
\text { SC }\end{array}$ & & \\
\hline 4 & 1 & $\begin{array}{l}\text { Ecological Services Conway, } \\
\text { AR }\end{array}$ & & \\
\hline 4 & 2 & $\begin{array}{l}\text { Ecological Services Daphne, } \\
\text { AL }\end{array}$ & & \\
\hline 4 & 1 & $\begin{array}{l}\text { Ecological Services Field } \\
\text { Office Athens, GA }\end{array}$ & & \\
\hline 4 & 4 & $\begin{array}{l}\text { Ecological Services Field } \\
\text { Office Panama City, FL }\end{array}$ & & \\
\hline
\end{tabular}




\begin{tabular}{|c|c|c|c|c|}
\hline Region & $\begin{array}{l}\text { Published } \\
\text { Authors }\end{array}$ & Org Unit & Website & Notes \\
\hline 4 & 1 & $\begin{array}{l}\text { Ecological Services Frankfort, } \\
\text { KY }\end{array}$ & & \\
\hline 4 & 4 & $\begin{array}{l}\text { Ecological Services Jackson, } \\
\text { MS }\end{array}$ & & \\
\hline 4 & 2 & $\begin{array}{l}\text { Ecological Services } \\
\text { Jacksonville, FL }\end{array}$ & & \\
\hline 4 & 1 & $\begin{array}{l}\text { Ecological Services Lafayette, } \\
\text { LA }\end{array}$ & & \\
\hline 4 & 2 & $\begin{array}{l}\text { Ecological Services Raleigh, } \\
\text { NC }\end{array}$ & & \\
\hline 4 & 2 & $\begin{array}{l}\text { Ecological Services Vero } \\
\text { Beach, FL }\end{array}$ & & \\
\hline 4 & 1 & $\begin{array}{l}\text { Florida Panther National } \\
\text { Wildlife Refuge }\end{array}$ & $\begin{array}{l}\text { http://floridapanther.fws.gov/in } \\
\text { dex.html }\end{array}$ & $\begin{array}{l}\text { Research is a major activity } \\
\text { on the refuge and most of this } \\
\text { work focuses on prescribed } \\
\text { fire and its impacts to refuge } \\
\text { resources. }\end{array}$ \\
\hline 4 & 1 & FWE_PAPR & & \\
\hline 4 & 1 & $\begin{array}{l}\text { Lacassine National Wildlife } \\
\text { Refuge }\end{array}$ & http://lacassine.fws.gov/index.htm & \\
\hline 4 & 1 & $\begin{array}{l}\text { Lower Mississippi River } \\
\text { Fisheries Coordination Office }\end{array}$ & & \\
\hline 4 & 1 & $\begin{array}{l}\text { Lower Suwannee River } \\
\text { National Wildlife Refuge }\end{array}$ & & \\
\hline 4 & 1 & $\begin{array}{l}\text { Loxahatchee National Wildlife } \\
\text { Refuge }\end{array}$ & $\begin{array}{l}\text { http://loxahatchee.fws.gov/hom } \\
\text { e/default.asp }\end{array}$ & $\begin{array}{l}\text { Research: Scientific research, } \\
\text { investigations and monitoring } \\
\text { projects on the refuge help us } \\
\text { to answer the what and why } \\
\text { questions about the } \\
\text { Everglades-both the wildlife } \\
\text { and their habitats. Projects } \\
\text { such as alligator surveys help } \\
\text { us understand how many } \\
\text { alligators there are, how } \\
\text { productive they are and how } \\
\text { they relate to the world around } \\
\text { them. Studies on tree islands } \\
\text { help us to learn their } \\
\text { importance to wildlife and } \\
\text { how changes in water } \\
\text { management may affect them. }\end{array}$ \\
\hline 4 & 1 & $\begin{array}{l}\text { Mississippi Sandhill Crane } \\
\text { National Wildlife Refuge }\end{array}$ & $\begin{array}{l}\text { http://mississippisandhillcrane.f } \\
\text { ws.gov/ }\end{array}$ & \\
\hline 4 & 2 & $\begin{array}{l}\text { National Key Deer National } \\
\text { Wildlife Refuge }\end{array}$ & $\begin{array}{l}\text { http://nationalkeydeer.fws.gov// } \\
\text { index.html }\end{array}$ & $\begin{array}{l}\text { Management tool: Deer } \\
\text { management as an endangered } \\
\text { species, including medical and } \\
\text { rehabilitation, habitat } \\
\text { restoration and enhancement, } \\
\text { routine herd health monitoring } \\
\text { and population checks, and } \\
\text { research on population } \\
\text { density, behavior and } \\
\text { migration patterns. }\end{array}$ \\
\hline 4 & 2 & $\begin{array}{l}\text { National Wildlife Refuge } \\
\text { System }\end{array}$ & & \\
\hline
\end{tabular}




\begin{tabular}{|c|c|c|c|c|}
\hline Region & $\begin{array}{l}\text { Published } \\
\text { Authors }\end{array}$ & Org Unit & Website & Notes \\
\hline 4 & 1 & $\begin{array}{l}\text { North Louisiana Refuges } \\
\text { Complex }\end{array}$ & $\begin{array}{l}\text { http://northlouisiana.fws.gov/in } \\
\text { dex.html }\end{array}$ & \\
\hline 4 & 4 & $\begin{array}{l}\text { Noxubee National Wildlife } \\
\text { Refuge }\end{array}$ & http://noxubee.fws.gov/ & \\
\hline 4 & 1 & $\begin{array}{l}\text { Okefenokee National Wildlife } \\
\text { Refuge }\end{array}$ & http://www.fws.gov/okefenokee/ & \\
\hline 4 & 5 & $\begin{array}{l}\text { Panama City Fishery Resource } \\
\text { Office, FL }\end{array}$ & & \\
\hline 4 & 1 & $\begin{array}{l}\text { Sabine National Wildlife } \\
\text { Refuge }\end{array}$ & http://www.fws.gov/sabine/index.html & \\
\hline 4 & 1 & $\begin{array}{l}\text { Mississippi Sandhill Crane } \\
\text { National Wildlife Refuge }\end{array}$ & $\begin{array}{l}\text { http://mississippisandhillcrane.f } \\
\text { ws.gov/ }\end{array}$ & $\begin{array}{l}\text { in cooperation with USGS } \\
\text { Patuxent Wildlife Research } \\
\text { Center }\end{array}$ \\
\hline 4 & 2 & Savannah Coastal Refuges & & \\
\hline 4 & 1 & SE Louisiana Refuges & $\begin{array}{l}\text { http://www.fws.gov/southeastlo } \\
\text { uisiana/ }\end{array}$ & \\
\hline 4 & 1 & $\begin{array}{l}\text { St. Marks National Wildlife } \\
\text { Refuge }\end{array}$ & http://www.fws.gov/saintmarks/ & \\
\hline 4 & 1 & $\begin{array}{l}\text { Tennessee National Wildlife } \\
\text { Refuge }\end{array}$ & http://www.fws.gov/tennesseerefuge/ & \\
\hline 4 & 2 & $\begin{array}{l}\text { Warm Springs Fish Health } \\
\text { Center }\end{array}$ & & \\
\hline 4 & 1 & $\begin{array}{l}\text { Warm Springs Fish } \\
\text { Technology Center }\end{array}$ & & \\
\hline 4 & 1 & $\begin{array}{l}\text { Wildlife Habitat and } \\
\text { Management Office Auburn }\end{array}$ & $\begin{array}{l}\text { http://fisheries.fws.gov/FTC/FT } \\
\text { Cwarms.htm }\end{array}$ & \\
\hline 41 & 66 & & & \\
\hline 3 & 2 & $\begin{array}{l}\text { Agassiz National Wildlife } \\
\text { Refuge }\end{array}$ & http://midwest.fws.gov/agassiz/ & $\begin{array}{l}\text { Refuge Objective \#6 } \\
\text { "Conduct Research" }\end{array}$ \\
\hline 3 & 1 & $\begin{array}{l}\text { Alpena Fishery Resources } \\
\text { Office }\end{array}$ & http://midwest.fws.gov/alpena/ & \\
\hline 3 & 2 & ARD Ecological Services & & \\
\hline 3 & 1 & $\begin{array}{l}\text { Ashland Fishery Resources } \\
\text { Office }\end{array}$ & $\begin{array}{l}\text { http://midwest.fws.gov/ashland/ } \\
\text { Mission.html }\end{array}$ & \\
\hline 3 & 1 & $\begin{array}{l}\text { Big Oaks National Wildlife } \\
\text { Refuge }\end{array}$ & $\begin{array}{l}\text { http://midwest.fws.gov/bigoaks } \\
\text { /bonwrintro.htmR }\end{array}$ & $\begin{array}{l}\text { Ball State professor Dr. } \\
\text { Kamal Islaam and graduate } \\
\text { student Kirk Roth and the } \\
\text { refuge staff are conducting a } \\
\text { 2-year study on habitat } \\
\text { selection and reproductive } \\
\text { success of cerulean warblers } \\
\text { at Big Oaks National Wildlife } \\
\text { Refuge }\end{array}$ \\
\hline 3 & 1 & $\begin{array}{l}\text { Carterville Fishery Resources } \\
\text { Office }\end{array}$ & http://midwest.fws.gov/Carterville/ & \\
\hline 3 & 1 & $\begin{array}{l}\text { Division of Bird Habitat } \\
\text { Initiatives }\end{array}$ & & \\
\hline 3 & 1 & $\begin{array}{l}\text { Driftless Area National } \\
\text { Wildlife Refuge }\end{array}$ & http://midwest.fws.gov/Driftless/ & \\
\hline 3 & 3 & $\begin{array}{l}\text { Ecological Services Field } \\
\text { Office Bloomington, IN }\end{array}$ & $\begin{array}{l}\text { http://midwest.fws.gov/Bloomi } \\
\text { ngton/ }\end{array}$ & $\begin{array}{l}\text { Develop biotic indicators and } \\
\text { status of coastal wetlands } \\
\text { within the entire Great Lakes } \\
\text { system }\end{array}$ \\
\hline
\end{tabular}




\begin{tabular}{|c|c|c|c|c|}
\hline Region & $\begin{array}{l}\text { Published } \\
\text { Authors }\end{array}$ & Org Unit & Website & Notes \\
\hline 3 & 3 & $\begin{array}{l}\text { Ecological Services Field } \\
\text { Office East Lansing, MI }\end{array}$ & http://midwest.fws.gov/EastLansing/ & $\begin{array}{l}\text { Apply problem-solving } \\
\text { attitude to natural resource } \\
\text { issues of federal interest in } \\
\text { Michigan and the Great Lakes } \\
\text { ecosystem }\end{array}$ \\
\hline 3 & 2 & $\begin{array}{l}\text { Ecological Services Field } \\
\text { Office Green Bay, WI }\end{array}$ & http://midwest.fws.gov/GreenBay & \\
\hline 3 & 2 & $\begin{array}{l}\text { Ecological Services Field } \\
\text { Office Rock Island, IL }\end{array}$ & http://midwest.fws.gov/RockIsland/ & $\begin{array}{l}\text { RIFO compiled an annotated } \\
\text { bibliography of threatened and } \\
\text { endangered species for the } \\
\text { Corps of Engineers } \\
\text { Navigation expansion study. - } \\
\text { RIFO led the development of } \\
\text { habitat based evaluations } \\
\text { using Habitat Evaluation } \\
\text { Procedure for site specific } \\
\text { habitat assessment studies at } \\
\text { locks and dams. }\end{array}$ \\
\hline 3 & 1 & $\begin{array}{l}\text { Ecological Services } \\
\text { Reynoldsburg, } \mathrm{OH}\end{array}$ & & \\
\hline 3 & 1 & $\begin{array}{l}\text { Ecological Services Twin } \\
\text { Cities, MN }\end{array}$ & http://midwest.fws.gov/TwinCities/ & $\begin{array}{l}\text { Investigate, prevent and } \\
\text { remediate effects of toxic } \\
\text { pollution to maximize quality } \\
\text { habitat for Service trust } \\
\text { species }\end{array}$ \\
\hline 3 & 1 & ES - Columbia, MO & http://midwest.fws.gov/ColumbiaES/ & $\begin{array}{l}\text { Investigate and remediate } \\
\text { effects on environment } \\
\text { contaminants on fish and } \\
\text { wildlife and coordinate } \\
\text { restoration of trust resources }\end{array}$ \\
\hline 3 & 1 & Genoa National Fish Hatchery & http://midwest.fws.gov/Genoa/ & \\
\hline 3 & 3 & $\begin{array}{l}\text { Green Bay Fishery Resources } \\
\text { Office }\end{array}$ & $\begin{array}{l}\text { http://midwest.fws.gov/GreenB } \\
\text { ayFisheries/ }\end{array}$ & \\
\hline 3 & 1 & La Crosse District & & \\
\hline 3 & 1 & LaCrosse Fish Health Center & $\begin{array}{l}\text { http://midwest.fws.gov/LaCross } \\
\text { eFishHealthCenter }\end{array}$ & $\begin{array}{l}\text { Research projects on } \\
\text { parasitological, viral and } \\
\text { bacteriological fish disease } \\
\text { agents }\end{array}$ \\
\hline 3 & 3 & $\begin{array}{l}\text { LaCrosse Fishery Resources } \\
\text { Office }\end{array}$ & $\begin{array}{l}\text { http://midwest.fws.gov/LaCross } \\
\text { eFisheries/ }\end{array}$ & \\
\hline 3 & 3 & Ludington Biostation & http://midwest.fws.gov/Ludington/ & $\begin{array}{l}\text { Activity Highlights: Develop } \\
\text { and implement enhanced } \\
\text { lamprey control techniques }\end{array}$ \\
\hline 3 & 1 & $\begin{array}{l}\text { Mark Twain National Wildlife } \\
\text { Refuge }\end{array}$ & http://midwest.fws.gov/marktwain/ & \\
\hline 3 & 16 & Marquette Biological Station & http://midwest.fws.gov/Marquette/ & \\
\hline 3 & 1 & $\begin{array}{l}\text { Migratory Birds and State } \\
\text { Programs }\end{array}$ & http://www.r1.fws.gov/mbsp/ & \\
\hline 3 & 1 & $\begin{array}{l}\text { Pendills Creek National Fish } \\
\text { Hatchery }\end{array}$ & $\begin{array}{l}\text { http://midwest.fws.gov/Pendills } \\
\text { Creek/ }\end{array}$ & \\
\hline 3 & 1 & Regional Director Region 3 & & \\
\hline
\end{tabular}




\begin{tabular}{|c|c|c|c|c|}
\hline Region & $\begin{array}{l}\text { Published } \\
\text { Authors }\end{array}$ & Org Unit & Website & Notes \\
\hline 3 & 1 & Regional Office-Fisheries & http://midwest.fws.gov/Fisheries/ & $\begin{array}{l}\text { Services the Fish Health } \\
\text { Center provides include fish } \\
\text { disease diagnostics, inspection } \\
\text { and certification of disease } \\
\text { presence in production } \\
\text { facilities, confirmation of } \\
\text { specific fish pathogens from } \\
\text { other health labs, applied } \\
\text { research, technical } \\
\text { information exchange and fish } \\
\text { health management training } \\
\text { for the people who work } \\
\text { directly with fish production. }\end{array}$ \\
\hline 3 & 1 & $\begin{array}{l}\text { Seney National Wildlife } \\
\text { Refuge }\end{array}$ & http://midwest.fws.gov/seney/ & \\
\hline 3 & 1 & $\begin{array}{l}\text { Tamarac National Wildlife } \\
\text { Refuge }\end{array}$ & http://midwest.fws.gov/Tamarac/ & \\
\hline 3 & 1 & $\begin{array}{l}\text { Upper Mississippi River } \\
\text { National Fish and Wildlife } \\
\text { Refuge }\end{array}$ & $\begin{array}{l}\text { http://midwest.fws.gov/Upper } \\
\text { MississippiRiver/ }\end{array}$ & \\
\hline 30 & 59 & 55 & & \\
\hline 2 & 1 & ARD Ecological Services & http://ifw2es.fws.gov/ & \\
\hline 2 & 4 & $\begin{array}{l}\text { Arizona Ecological Services } \\
\text { Field Office }\end{array}$ & http://arizonaes.fws.gov/ & \\
\hline 2 & 2 & $\begin{array}{l}\text { Arizona Fishery Resource } \\
\text { Office Flagstaff, AZ }\end{array}$ & & \\
\hline 2 & 1 & $\begin{array}{l}\text { Bosque Del Apache National } \\
\text { Wildlife Refuge }\end{array}$ & $\begin{array}{l}\text { http://www.fws.gov/southwest/ } \\
\text { refuges/newmex/bosque/index. } \\
\text { html }\end{array}$ & \\
\hline 2 & 1 & $\begin{array}{l}\text { Deep Fork National Wildlife } \\
\text { Refuge }\end{array}$ & $\begin{array}{l}\text { http://www.fws.gov/southwest/ } \\
\text { refuges/oklahoma/deep\%20fork } \\
\text { /index.html }\end{array}$ & \\
\hline 2 & 1 & $\begin{array}{l}\text { Dexter National Fish Hatchery } \\
\text { and Technology Center }\end{array}$ & $\begin{array}{l}\text { http://fisheries.fws.gov/FTC/FT } \\
\text { Cdexter.htm }\end{array}$ & \\
\hline 2 & 3 & Division of Migratory Birds & & \\
\hline 2 & 1 & Ecological Services Austin, TX & $\begin{array}{l}\text { http://ifw2es.fws.gov/TexasOffi } \\
\text { ces.cfm }\end{array}$ & \\
\hline 2 & 1 & $\begin{array}{l}\text { Ecological Services Field } \\
\text { Office Arlington }\end{array}$ & http://www.fws.gov/arlingtontexas/ & \\
\hline 2 & 2 & $\begin{array}{l}\text { Ecological Services Field } \\
\text { Office Corpus Christi, TX }\end{array}$ & $\begin{array}{l}\text { http://ifw2es.fws.gov/CorpusCh } \\
\text { ristiTexas/ }\end{array}$ & \\
\hline 2 & 1 & $\begin{array}{l}\text { Ecological Services Field } \\
\text { Office Houston, TX }\end{array}$ & & \\
\hline 2 & 1 & $\begin{array}{l}\text { Fishery Resource Office } \\
\text { Parker, AZ }\end{array}$ & & \\
\hline 2 & 2 & $\begin{array}{l}\text { Laguna Atascosa National } \\
\text { Wildlife Refuge }\end{array}$ & $\begin{array}{l}\text { http://www.fws.gov/southwest/ } \\
\text { refuges/texas/laguna.html }\end{array}$ & \\
\hline 2 & 2 & $\begin{array}{l}\text { Lower Rio Grande Valley } \\
\text { National Wildlife Refuge }\end{array}$ & $\begin{array}{l}\text { http://www.fws.gov/southwest/ } \\
\text { refuges/texas/lrgv.html }\end{array}$ & \\
\hline 2 & 1 & $\begin{array}{l}\text { McFaddin National Wildlife } \\
\text { Refuge }\end{array}$ & $\begin{array}{l}\text { http://www.fws.gov/southwest/refu } \\
\text { ges/texas/mcfaddin/index.html }\end{array}$ & \\
\hline 2 & 1 & $\begin{array}{l}\text { Mescalero National Fish } \\
\text { Hatchery }\end{array}$ & & \\
\hline 2 & 2 & Mora National Fish Hatchery & $\begin{array}{l}\text { http://fisheries.fws.gov/FTC/FT } \\
\text { Cdexter.htm }\end{array}$ & \\
\hline
\end{tabular}




\begin{tabular}{|c|c|c|c|c|}
\hline Region & $\begin{array}{l}\text { Published } \\
\text { Authors }\end{array}$ & Org Unit & Website & Notes \\
\hline 2 & 3 & $\begin{array}{l}\text { New Mexico Ecological } \\
\text { Services Field Office }\end{array}$ & & \\
\hline 2 & 2 & $\begin{array}{l}\text { New Mexico Fishery } \\
\text { Resources Office }\end{array}$ & & \\
\hline 2 & 4 & $\begin{array}{l}\text { Oklahoma Ecological Services } \\
\text { Field Office }\end{array}$ & http://ifw2es.fws.gov/Oklahoma/ & \\
\hline 2 & 1 & $\begin{array}{l}\text { Ozark Plateau National } \\
\text { Wildlife Refuge }\end{array}$ & $\begin{array}{l}\text { http://www.fws.gov/southwest/refu } \\
\text { ges/oklahoma/ozark/index.html }\end{array}$ & \\
\hline 2 & 1 & $\begin{array}{l}\text { San Bernardino/Leslie Canyon } \\
\text { National Wildlife Refuge }\end{array}$ & $\begin{array}{l}\text { http://www.fws.gov/southwest/ } \\
\text { refuges/arizona/sanb.html }\end{array}$ & \\
\hline 2 & 3 & $\begin{array}{l}\text { San Marcos National Fish } \\
\text { Hatchery and Technology } \\
\text { Center }\end{array}$ & $\begin{array}{l}\text { http://fisheries.fws.gov/FTC/FT } \\
\text { Csanmrs.htm }\end{array}$ & $\begin{array}{l}\text { Conduct research on life } \\
\text { history, ecological } \\
\text { requirements, genetics, and } \\
\text { culture - Conduct research on } \\
\text { restocking refugium species }\end{array}$ \\
\hline 2 & 1 & Service Aviation Manager & & \\
\hline 2 & 1 & $\begin{array}{l}\text { Sevilleta National Wildlife } \\
\text { Refuge }\end{array}$ & & $\begin{array}{l}\text { Sevilleta NWR is managed } \\
\text { primarily as a research area, } \\
\text { and is closed to most } \\
\text { recreational uses. }\end{array}$ \\
\hline 2 & 1 & $\begin{array}{l}\text { Willow Beach National Fish } \\
\text { Hatchery }\end{array}$ & & \\
\hline 27 & 44 & 43 & & \\
\hline 1 & 6 & $\begin{array}{l}\text { Abernathy Salmon Fish } \\
\text { Technology Center }\end{array}$ & http://pacific.fws.gov/aftc & $\begin{array}{l}\text { The major emphases of the } \\
\text { Center is applied research } \\
\text { (Conduct applied research } \\
\text { studies at National Fish } \\
\text { Hatcheries to examine effects } \\
\text { of natural rearing practices.) }\end{array}$ \\
\hline 1 & 2 & Arcata Fish and Wildlife Office & http://arcata.fws.gov/ & \\
\hline 1 & 2 & $\begin{array}{l}\text { Big Island National Wildlife } \\
\text { Refuge Complex }\end{array}$ & $\begin{array}{l}\text { http://www.fws.gov/pacific/pacifici } \\
\text { slands/wnwr/bignwrindex.html }\end{array}$ & \\
\hline 1 & 4 & CA/NV Fish Health Center & & \\
\hline 1 & 2 & CA/NV Operations Office & & \\
\hline 1 & 9 & $\begin{array}{l}\text { Carlsbad Fish and Wildlife } \\
\text { Office }\end{array}$ & http://www.fws.gov/pacific/carlsbad/ & \\
\hline 1 & 1 & $\begin{array}{l}\text { Coleman National Fish } \\
\text { Hatchery }\end{array}$ & & \\
\hline 1 & 6 & $\begin{array}{l}\text { Columbia River Fisheries } \\
\text { Program Office }\end{array}$ & http://columbiariver.fws.gov/ & $\begin{array}{l}\text { The CRFPO also provides for } \\
\text { science-based management of } \\
\text { aquatic resources on federal } \\
\text { and tribal lands in the area } \\
\text { from the Columbia River } \\
\text { mouth upstream - conducts } \\
\text { interagency research - The } \\
\text { CAT-Team may also provide } \\
\text { guidance on experimental } \\
\text { design, modeling and analysis } \\
\text { for FWS research and } \\
\text { monitoring projects } \\
\text { (http://columbiariver.fws.gov/ } \\
\text { programs.htm) }\end{array}$ \\
\hline 1 & 1 & $\begin{array}{l}\text { Colusa National Wildlife } \\
\text { Refuge }\end{array}$ & $\begin{array}{l}\text { http://www.fws.gov/pacific/sacra } \\
\text { mentovalleyrefuges/colusa.htm }\end{array}$ & \\
\hline 1 & 1 & Division of Engineering & & \\
\hline
\end{tabular}




\begin{tabular}{|c|c|c|c|c|}
\hline Region & $\begin{array}{l}\text { Published } \\
\text { Authors }\end{array}$ & Org Unit & Website & Notes \\
\hline 1 & 1 & $\begin{array}{l}\text { Division of Migratory Bird } \\
\text { Management }\end{array}$ & & \\
\hline 1 & 2 & $\begin{array}{l}\text { Division of Migratory Birds } \\
\text { and Habitat Programs }\end{array}$ & & \\
\hline 1 & 6 & $\begin{array}{l}\text { Ecological Services Field } \\
\text { Office Pacific Islands }\end{array}$ & & \\
\hline 1 & 2 & Environmental Contaminants & & \\
\hline 1 & 1 & $\begin{array}{l}\text { Hanford Reach National } \\
\text { Monument/Saddle Mountain } \\
\text { NWR }\end{array}$ & http://hanfordreach.fws.gov/ & $\begin{array}{l}\text { The Monument supports a } \\
\text { variety of approved research, } \\
\text { survey and inventory projects. } \\
\text { Current research subjects } \\
\text { include burrowing owls, } \\
\text { butterflies, migratory and } \\
\text { resident songbirds, } \\
\text { amphibians and reptiles, } \\
\text { invasive species, microbiotic } \\
\text { crust, migratory waterfowl, } \\
\text { salmonid and riverine species, } \\
\text { and shrub-steppe restoration. }\end{array}$ \\
\hline 1 & 1 & $\begin{array}{l}\text { Humboldt Bay National } \\
\text { Wildlife Refuge }\end{array}$ & http://pacific.fws.gov/humboldtbay/ & \\
\hline 1 & 1 & Idaho Fish Health Center & http://idfishhealth.fws.gov/ & $\begin{array}{l}\text { The Idaho Fish Health Center } \\
\text { (IFHC) is co-located with } \\
\text { Dworshak National Fish } \\
\text { Hatchery } \\
\text { (http://idfishhealth.fws.gov/re } \\
\text { search.htm - Skin } \\
\text { Reflectance) }\end{array}$ \\
\hline 1 & 4 & Idaho Fishery Resource Office & http://idahofro.fws.gov/ & \\
\hline 1 & 1 & $\begin{array}{l}\text { Kauai National Wildlife } \\
\text { Refuge Complex }\end{array}$ & $\begin{array}{l}\text { http://www.fws.gov/pacific/pac } \\
\text { ificislands/wnwr/kauainwrinde } \\
\text { x.html }\end{array}$ & \\
\hline 1 & 1 & $\begin{array}{l}\text { Klamath Basin National } \\
\text { Wildlife Refuge Complex }\end{array}$ & http://klamathbasinrefuges.fws.gov/ & \\
\hline 1 & 1 & $\begin{array}{l}\text { Klamath Falls Fish and } \\
\text { Wildlife Office }\end{array}$ & & \\
\hline 1 & 1 & $\begin{array}{l}\text { Kooskia National Fish } \\
\text { Hatchery }\end{array}$ & & \\
\hline 1 & 1 & $\begin{array}{l}\text { Kootenai National Wildlife } \\
\text { Refuge }\end{array}$ & & \\
\hline 1 & 1 & $\begin{array}{l}\text { Lahontan National Fish } \\
\text { Hatchery }\end{array}$ & & \\
\hline 1 & 1 & $\begin{array}{l}\text { Leavenworth National Fish } \\
\text { Hatchery Complex }\end{array}$ & $\begin{array}{l}\text { http://leavenworth.fws.gov/proj } \\
\text { ects.htm }\end{array}$ & \\
\hline 1 & 2 & $\begin{array}{l}\text { Little White Salmon/ Willard } \\
\text { National Fish Health Center }\end{array}$ & & \\
\hline 1 & 1 & $\begin{array}{l}\text { Malheur National Wildlife } \\
\text { Refuge }\end{array}$ & http://malheur.fws.gov/ & \\
\hline 1 & 1 & $\begin{array}{l}\text { Nevada Fish and Wildlife } \\
\text { Office }\end{array}$ & & \\
\hline 1 & 2 & $\begin{array}{l}\text { Nisqually National Wildlife } \\
\text { Refuge Complex }\end{array}$ & http://nisqually.fws.gov/ & \\
\hline 1 & 1 & Oahu National Wildlife Refuge & $\begin{array}{l}\text { http://www.fws.gov/pacific/pacifici } \\
\text { slands/wnwr/oahunwrindex.html }\end{array}$ & \\
\hline 1 & 1 & Olympia Fish Hatchery Center & http://olympiafishhealth.fws.gov/ & Provides technical services \\
\hline
\end{tabular}




\begin{tabular}{|c|c|c|c|c|}
\hline Region & $\begin{array}{l}\text { Published } \\
\text { Authors }\end{array}$ & Org Unit & Website & Notes \\
\hline 1 & 1 & $\begin{array}{l}\text { Oregon Coast National } \\
\text { Wildlife Refuge Complex }\end{array}$ & $\begin{array}{l}\text { http://www.fws.gov/pacific/ore } \\
\text { goncoast/ }\end{array}$ & \\
\hline 1 & 3 & $\begin{array}{l}\text { Oregon Fish and Wildlife } \\
\text { Office }\end{array}$ & http://oregonfwo.fws.gov/ & \\
\hline 1 & 3 & $\begin{array}{l}\text { Pacific Islands National } \\
\text { Wildlife Refuge Complex }\end{array}$ & $\begin{array}{l}\text { http://www.fws.gov/pacific/pac } \\
\text { ificislands/ }\end{array}$ & \\
\hline 1 & 1 & $\begin{array}{l}\text { Red Bluff Fish and Wildlife } \\
\text { Office }\end{array}$ & & \\
\hline 1 & 1 & $\begin{array}{l}\text { Ruby Lake National Wildlife } \\
\text { Refuge }\end{array}$ & $\begin{array}{l}\text { http://pacific.fws.gov/refuges/fi } \\
\text { eld/NV_rubylk.htm }\end{array}$ & \\
\hline 1 & 9 & $\begin{array}{l}\text { Sacramento Fish and Wildlife } \\
\text { Office }\end{array}$ & & \\
\hline 1 & 2 & $\begin{array}{l}\text { Sacramento National Wildlife } \\
\text { Refuge Complex }\end{array}$ & $\begin{array}{l}\text { http://www.fws.gov/pacific/sacra } \\
\text { mentovalleyrefuges/index.htm }\end{array}$ & $\begin{array}{l}\text { Research is encouraged, and } \\
\text { staff is involved with } \\
\text { initiating and conducting } \\
\text { studies that have direct } \\
\text { applications to management. } \\
\text { Recent examples include } \\
\text { studies on the effects of } \\
\text { mosquito abatement activities } \\
\text { on refuge biota, giant garter } \\
\text { snake ecology, and causes of } \\
\text { avian cholera outbreaks. }\end{array}$ \\
\hline 1 & 1 & $\begin{array}{l}\text { San Diego National Wildlife } \\
\text { Refuge Complex }\end{array}$ & $\begin{array}{l}\text { http://www.fws.gov/pacific/san } \\
\text { diegorefuges/south_bay.htm }\end{array}$ & \\
\hline 1 & 1 & $\begin{array}{l}\text { San Francisco Bay National } \\
\text { Wildlife Refuge Complex }\end{array}$ & & \\
\hline 1 & 2 & $\begin{array}{l}\text { SE Idaho National Wildlife } \\
\text { Refuge Complex }\end{array}$ & $\begin{array}{l}\text { http://pacific.fws.gov/refuges/fi } \\
\text { eld/ID_seid.htm }\end{array}$ & \\
\hline 1 & 2 & $\begin{array}{l}\text { Sheldon Hart National Wildlife } \\
\text { Refuge }\end{array}$ & http://sheldon-hartmtn.fws.gov/ & \\
\hline 1 & 2 & $\begin{array}{l}\text { Snake River Basin Fish and } \\
\text { Wildlife Office }\end{array}$ & & \\
\hline 1 & 1 & $\begin{array}{l}\text { Stillwater National Wildlife } \\
\text { Refuge }\end{array}$ & & \\
\hline 1 & 1 & $\begin{array}{l}\text { Stockton Fish and Wildlife } \\
\text { Office }\end{array}$ & http://www.delta.dfg.ca.gov/usfws/ & \\
\hline 1 & 5 & $\begin{array}{l}\text { Upper Columbia Fish and } \\
\text { Wildlife Office }\end{array}$ & & Provides technical services \\
\hline 1 & 1 & $\begin{array}{l}\text { Ventura Fish and Wildlife } \\
\text { Office }\end{array}$ & & \\
\hline 1 & 1 & $\begin{array}{l}\text { Washington Maritime National } \\
\text { Wildlife Refuge Complex }\end{array}$ & & \\
\hline 1 & 6 & $\begin{array}{l}\text { Western Washington Fish and } \\
\text { Wildlife Office }\end{array}$ & & \\
\hline 1 & 1 & $\begin{array}{l}\text { Willapa National Wildlife } \\
\text { Refuge Complex }\end{array}$ & http://willapa.fws.gov/ & \\
\hline 1 & 1 & Yreka Fish and Wildlife Office & & \\
\hline 50 & 112 & & & \\
\hline
\end{tabular}




\section{Appendix 3A. Regional Appendices}

\section{All FWS}

\section{Latent Content Analysis Results}

Total number of position descriptions (PDs) coded for FWS = 244

Number of PDs from published individuals $=125$

Number of PDs from non published individuals $=119$

Percentages are rounded and may not total 100.

\section{Publication Status}

Each coding category was analyzed using a Chi-square, Fisher's exact test when necessary due to sparseness, to determine if the category related to whether or not a person had published. Significant $($ at $p<.05)$ results were found for the following categories:

(1-2) Research planning - Design research study/data collection method $\chi^{2}=9.60$

$p h i=.20$. This measure of the strength of the association indicates a moderate relationship.

\section{Category 1-2 present in PD?}

\begin{tabular}{r|ccc}
\multicolumn{1}{c}{} & \multicolumn{1}{c}{ Publication status } \\
\multicolumn{1}{c}{} & No & Yes & Total \\
\cline { 2 - 4 } No & 84 & 64 & 148 \\
Yes & 35 & 61 & 96 \\
Total & 119 & 125 & 244
\end{tabular}

Of the people who had published, $49 \%$ of them had category 1-2 content in their PDs.

Of the people who had category 1-2 content in their PDs, $64 \%$ of them had published.

(3-1) Research analyses - Analyze data using qualitative or quantitative methods.

$\chi^{2}=8.86$

$p h i=.19$. This measure of the strength of the association indicates a moderate relationship.

\section{Category 3-1 present in PD?}

Of the people who had published, $48 \%$ of them had category 3-1 content in their PDs.

\section{Publication status}

\begin{tabular}{rccc}
\multicolumn{1}{c}{} & No & Yes & Total \\
\cline { 2 - 4 } No & 84 & 65 & 149 \\
Yes & 35 & 60 & 95 \\
Total & 119 & 125 & 244
\end{tabular}

Of the people who had category 3-1 content in their PDs, 63\% of them had published. 
(4-1) Research dissemination - Write reports from data

$\chi^{2}=5.57$

$p h i=.15$. This measure of the strength of the association indicates a weak relationship.

\section{Category 4-1 present in PD?}

\begin{tabular}{|c|c|c|c|}
\hline & \multicolumn{3}{|c|}{ Publication status } \\
\hline & No & Yes & Total \\
\hline No & 99 & 88 & 187 \\
\hline Yes & 20 & 37 & 57 \\
\hline Total & 119 & 125 & 244 \\
\hline
\end{tabular}

Of the people who had published, $30 \%$ of them had category 4-1 content in their PDs.

Of the people who had category 4-1 content in their PDs, $65 \%$ of them had published.

(5-1) Research application - Use research-based information to evaluate or inform management actions.

$\chi^{2}=7.04$

$p h i=.17$. This measure of the strength of the association indicates a weak relationship.

\section{Category 5-1 present in PD?}

\begin{tabular}{|c|c|c|c|}
\hline & \multicolumn{3}{|c|}{ Publication status } \\
\hline & No & Yes & Total \\
\hline No & 79 & 62 & 141 \\
\hline Yes & 40 & 63 & 103 \\
\hline Total & 119 & 125 & 244 \\
\hline
\end{tabular}

Of the people who had published, 50\% of them had category 5-1 content in their PDs.

Of the people who had category 5-1 content in their PDs, $61 \%$ of them had published.

(6-1) Research collaboration - Collaborate with non-FWS personnel on research projects.

$\chi^{2}=10.94$

$p h i=.21$. This measure of the strength of the association indicates a moderate relationship.

\section{Category 6-1 present in PD?}

\begin{tabular}{|c|c|c|c|}
\hline & & ation & \\
\hline & No & Yes & Total \\
\hline No & 93 & 73 & 166 \\
\hline Yes & 26 & 52 & 78 \\
\hline Total & 119 & 125 & 244 \\
\hline
\end{tabular}

Of the people who had published, $42 \%$ of them had category 6-1 content in their PDs.

Of the people who had category 6-1 content in their PDs, $67 \%$ of them had published.

(7-1) Knowledge/Skill/Ability Required-Statistical data analysis

$\chi^{2}=9.22$

$p h i=.19$. This measure of the strength of the association indicates a moderate relationship.

\section{Category 7-1 present in PD?}

Of the people who had published, 52\% of them had category 7-1 content in their PDs.

\section{Publication status}

\begin{tabular}{rccc}
\multicolumn{1}{r}{} & No & Yes & Total \\
\cline { 2 - 4 } No & 80 & 60 & 140 \\
Yes & 39 & 65 & 104 \\
Total & 119 & 125 & 244
\end{tabular}

Of the people who had category 7-1 content in their PDs, $63 \%$ of them had published. 
(7-2) Knowledge/Skill/Ability Required-Research methods

$\chi^{2}=14.91$

$p h i=.25$. This measure of the strength of the association indicates a moderate relationship.

Category 7-2 present in PD?

\begin{tabular}{|c|c|c|c|}
\hline & \multicolumn{3}{|c|}{ Publication status } \\
\hline & No & Yes & Total \\
\hline No & 77 & 50 & 127 \\
\hline Yes & 42 & 75 & 117 \\
\hline Total & 119 & 125 & 244 \\
\hline
\end{tabular}

Of the people who had published, $60 \%$ of them had category 7-2 content in their PDs.

Of the people who had category 7-2 content in their PDs, $64 \%$ of them had published.

(7-3) Knowledge/Skill/Ability Required- Statistical software

$\chi^{2}=4.45$

$p h i=.14$. This measure of the strength of the association indicates a weak relationship.

\section{Category 7-3 present in PD?}

\begin{tabular}{rccc}
\multicolumn{1}{c}{} & \multicolumn{3}{c}{ Publication status } \\
\multicolumn{1}{c}{} & No & Yes & Total \\
\cline { 2 - 4 } No & 111 & 106 & 217 \\
Yes & 8 & 19 & 27 \\
Total & 119 & 125 & 244
\end{tabular}

Of the people who had published, $15 \%$ of them had category 7-3 content in their PDs.

Of the people who had category 7-3 content in their PDs, $70 \%$ of them had published.

\section{GS Level}

Due to small sample sizes at GS 7, 9 and 15, the analyses were limited to GS levels in the range from 11 to 14 . However, frequencies for the entire range of GS levels are provided. Each coding category was analyzed using a Chi-square to determine if the category related to the GS level of the PD. Significant (at $p<.05)$ results were found for the following categories:

(1-2) Research planning - Design research study/data collection method

$\chi^{2}=18.39$

Cramer's V $=.29$. This measure of the strength of the association indicates a moderate relationship.

Category 1-2 present in PD?

\begin{tabular}{rcccccccc}
\multicolumn{1}{c}{} & \multicolumn{8}{c}{ GS level } \\
\cline { 3 - 10 } & $\mathbf{7}$ & $\mathbf{9}$ & $\mathbf{1 1}$ & $\mathbf{1 2}$ & $\mathbf{1 3}$ & $\mathbf{1 4}$ & $\mathbf{1 5}$ & Total \\
\cline { 2 - 10 } Nes & 1 & 4 & 24 & 42 & 51 & 18 & 8 & 148 \\
Total & 0 & 6 & 31 & 36 & 21 & 2 & 0 & 96 \\
& 1 & 10 & 55 & 78 & 72 & 20 & 8 & 244
\end{tabular}

$60 \%$ of GS-9, $56 \%$ of GS-11, $46 \%$ of GS-12, $29 \%$ of GS-13, and 10\% of GS-14 position descriptions had category $1-2$ content.

Of the GS 11-14 people who had category 1-2 content in their PDs, 34\% were GS-11, 40\% were GS-12, 23\% were GS-13, and 2\% were GS-14. 
(2-1) Research execution - Collect data

$\chi^{2}=23.58$

Cramer's $V=.32$. This measure of the strength of the association indicates a moderately strong relationship.

\section{Category 2-1 present in PD?}

\begin{tabular}{r|cccccccc}
\multicolumn{10}{c}{} & \multicolumn{8}{c}{ GS level } \\
\cline { 2 - 9 } \multicolumn{1}{c}{} & $\mathbf{7}$ & $\mathbf{9}$ & $\mathbf{1 1}$ & $\mathbf{1 2}$ & $\mathbf{1 3}$ & $\mathbf{1 4}$ & $\mathbf{1 5}$ & Total \\
\cline { 2 - 10 } Yes & 0 & 3 & 23 & 44 & 55 & 18 & 8 & 151 \\
Total & 1 & 7 & 32 & 34 & 17 & 2 & 0 & 93 \\
& 1 & 10 & 55 & 78 & 72 & 20 & 8 & 244
\end{tabular}

$100 \%$ of GS-7, $70 \%$ of GS-9, $58 \%$ of GS-11, $44 \%$ of GS-12, 24\% of GS-13, and 10\% of GS-14 position descriptions had category 2-1 content.

Of the GS 11-14 people who had category 2-1 content in their PDs, 38\% were GS-11, 40\% were GS-12, $20 \%$ were GS-13, and $2 \%$ were GS-14.

(2-5) Research execution - Conduct Inventories/Field studies

$\chi^{2}=21.75$

Cramer's $\mathrm{V}=.31$. This measure of the strength of the association indicates a moderately strong relationship.

\section{Category 2-5 present in PD?}

\begin{tabular}{r|cccccccc}
\multicolumn{10}{c}{} & \multicolumn{8}{c}{ GS level } \\
\cline { 2 - 9 } & $\mathbf{7}$ & $\mathbf{9}$ & $\mathbf{1 1}$ & $\mathbf{1 2}$ & $\mathbf{1 3}$ & $\mathbf{1 4}$ & $\mathbf{1 5}$ & Total \\
\cline { 2 - 10 } Nos & 1 & 3 & 27 & 46 & 60 & 17 & 8 & 162 \\
Total & 0 & 7 & 28 & 32 & 12 & 3 & 0 & 82 \\
& 1 & 10 & 55 & 78 & 72 & 20 & 8 & 244
\end{tabular}

$70 \%$ of GS-9, $51 \%$ of GS-11, $41 \%$ of GS-12, $17 \%$ of GS-13, and 15\% of GS-14 position descriptions had category $2-5$ content.

Of the GS 11-14 people who had category 2-5 content in their PDs, 37\% were GS-11, 43\% were GS-12, $16 \%$ were GS-13, and 4\% were GS-14.

(2-6) Research execution - Conduct monitoring

$\chi^{2}=9.34$

Cramer's $\mathrm{V}=.20$. This measure of the strength of the association indicates a moderate relationship.

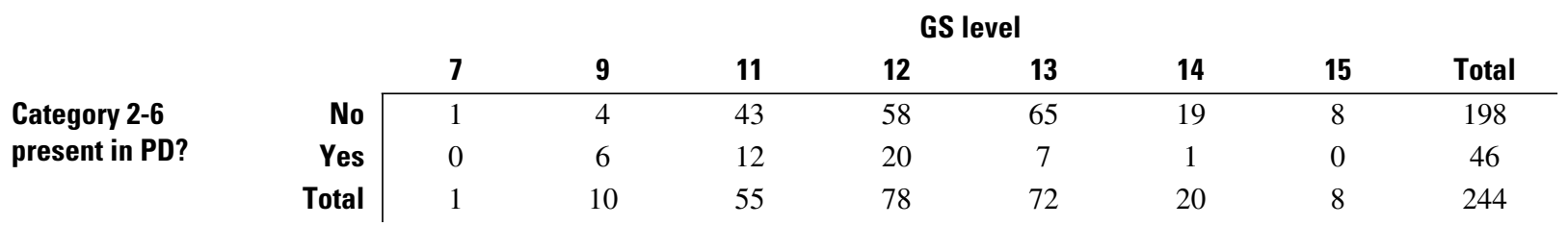

$60 \%$ of GS-9, $26 \%$ of GS-11, 43\% of GS-12, $15 \%$ of GS-13, and 5\% of GS-14 position descriptions had category $2-6$ content.

Of the GS 11-14 people who had category 2-6 content in their PDs, 30\% were GS-11, 50\% were GS-12, $18 \%$ were GS-13, and 3\% were GS-14.

(3-1) Research analyses - Analyze data using qualitative or quantitative methods.

$\chi^{2}=15.96$

Cramer's $\mathrm{V}=.27$. This measure of the strength of the association indicates a moderate relationship.

Category 3-1 present in PD?

\begin{tabular}{r|cccccccc}
\multicolumn{10}{c}{} & \multicolumn{9}{c}{ GS level } & \multicolumn{1}{c}{} & \multicolumn{1}{c}{ Total } \\
\cline { 2 - 9 } No & $\mathbf{7}$ & $\mathbf{9}$ & $\mathbf{1 1}$ & $\mathbf{1 2}$ & $\mathbf{1 3}$ & $\mathbf{1 4}$ & $\mathbf{1 5}$ & 149 \\
Yes & 1 & 3 & 28 & 39 & 53 & 17 & 8 & 95 \\
Total & 0 & 7 & 27 & 39 & 19 & 3 & 0 & 244
\end{tabular}

$70 \%$ of GS-9, $49 \%$ of GS-11, 50\% of GS-12, $26 \%$ of GS-13 and $15 \%$ of GS-14 position descriptions had category $3-1$ content. 
(4-1) Research dissemination - Write reports from data.

$\chi^{2}=17.63$

Cramer's $\mathrm{V}=.28$. This measure of the strength of the association indicates a moderate relationship.

\section{Category 4-1 present in PD?}

\begin{tabular}{|c|c|c|c|c|c|c|c|c|}
\hline & \multicolumn{8}{|c|}{ GS level } \\
\hline & 7 & 9 & 11 & 12 & 13 & 14 & 15 & Total \\
\hline No & 1 & 7 & 37 & 51 & 64 & 19 & 8 & 187 \\
\hline Yes & 0 & 3 & 18 & 27 & 8 & 1 & 0 & 57 \\
\hline Total & 1 & 10 & 55 & 78 & 72 & 20 & 8 & 244 \\
\hline
\end{tabular}

$30 \%$ of GS-9, 33\% of GS-11, 35\% of GS-12, 11\% of GS-13 and 5\% of GS-14 position descriptions had category 4-1 content.

Of the GS 11-14 people who had category 4-1 content in their PDs, 33\% were GS-11, 50\% were GS-12, $15 \%$ were GS-13, and $2 \%$ were GS-14.

(4-2) Research dissemination - Publication

$\chi^{2}=9.76$

Cramer's $\mathrm{V}=.21$. This measure of the strength of the association indicates a moderate relationship.

Category 4-2 present in PD?

\begin{tabular}{r|cccccccc}
\multicolumn{1}{c}{} & \multicolumn{8}{c}{ GS level } \\
\cline { 2 - 9 } & $\mathbf{7}$ & $\mathbf{9}$ & $\mathbf{1 1}$ & $\mathbf{1 2}$ & $\mathbf{1 3}$ & $\mathbf{1 4}$ & $\mathbf{1 5}$ & Total \\
Nes & 1 & 9 & 47 & 63 & 68 & 20 & 8 & 216 \\
Total & 0 & 1 & 8 & 15 & 4 & 0 & 0 & 28 \\
& 1 & 10 & 55 & 78 & 72 & 20 & 8 & 244
\end{tabular}

$10 \%$ of GS-9, $15 \%$ of GS-11, $19 \%$ of GS-12, and $6 \%$ of GS-13 position descriptions had category 4-2 content.

Of the GS 11-14 people who had category 4-2 content in their PDs, 30\% were GS-11, 56\% were GS-12, and 15\% were GS-13.

(7-1) Knowledge/Skill/Ability Required - Statistical data analysis

$\chi^{2}=15.88$

Cramer's $V=.27$. This measure of the strength of the association indicates a moderate relationship.

Category 7-1 present in PD?

\begin{tabular}{r|cccccccc}
\multicolumn{1}{c}{} & \multicolumn{8}{c}{ GS level } \\
\cline { 2 - 9 } & $\mathbf{7}$ & $\mathbf{9}$ & $\mathbf{1 1}$ & $\mathbf{1 2}$ & $\mathbf{1 3}$ & $\mathbf{1 4}$ & $\mathbf{1 5}$ & Total \\
\cline { 2 - 10 } Yes & 1 & 3 & 25 & 37 & 49 & 17 & 8 & 140 \\
Total & 0 & 7 & 30 & 41 & 23 & 3 & 0 & 104 \\
& 1 & 10 & 55 & 78 & 72 & 20 & 8 & 244
\end{tabular}

$70 \%$ of GS-9, $55 \%$ of GS-11, 53\% of GS-12, 32\% of GS-13, and 15\% of GS-14 position descriptions had category 7-1 content.

Of the GS 11-14 people who had category 7-1 content in their PDs, 31\% were GS-11, 42\% were GS-12, 24\% were GS-13, and 3\% were GS-14.

(7-4) Knowledge/Skill/Ability Required - Document preparation

$\chi^{2}=7.96$

Cramer's $V=.19$. This measure of the strength of the association indicates a moderate relationship.

Category 7-4 present in PD?

\begin{tabular}{r|cccccccc}
\multicolumn{1}{c}{} & \multicolumn{9}{c}{ GS level } \\
\cline { 3 - 9 } & $\mathbf{7}$ & $\mathbf{9}$ & $\mathbf{1 1}$ & $\mathbf{1 2}$ & $\mathbf{1 3}$ & $\mathbf{1 4}$ & $\mathbf{1 5}$ & Total \\
\cline { 2 - 10 } Nos & 1 & 5 & 38 & 55 & 61 & 18 & 8 & 186 \\
Total & 0 & 5 & 17 & 23 & 11 & 2 & 0 & 58 \\
& 1 & 10 & 55 & 78 & 72 & 20 & 8 & 244
\end{tabular}

$50 \%$ of GS-9, $31 \%$ of GS-11, $29 \%$ of GS-12, $15 \%$ of GS-13, and $10 \%$ of GS-14 position descriptions had category $7-4$ content. 


\section{Occupational Classification}

Due to small sample sizes for some occupational classifications, the analyses were limited to the occupational classifications of 401,480, 482, 485, and 486. However, frequencies for the entire range of occupational classifications are provided. Each coding category was analyzed using a Chi-square to determine if the category related to the occupational classification of the PD. Significant (at $p<.05)$ results were found for the following categories:

(1-2) Research planning - Design research study/data collection method $\chi^{2}=21.80$

Cramer's $V=.31$. This measure of the strength of the association indicates a moderately strong relationship.

Occupational classification

\begin{tabular}{|c|c|c|c|c|c|c|c|c|c|c|c|c|c|c|c|c|}
\hline \multirow{4}{*}{$\begin{array}{l}\text { Category 1-2 } \\
\text { present in PD? }\end{array}$} & & 170 & 193 & 301 & 401 & 408 & 430 & 454 & 480 & 482 & 485 & 486 & 701 & 1320 & 1530 & Total \\
\hline & No & 1 & 0 & 1 & 46 & 0 & 0 & 1 & 15 & 36 & 17 & 29 & 0 & 1 & 1 & 148 \\
\hline & Yes & 0 & 1 & 0 & 25 & 1 & 1 & 0 & 0 & 26 & 3 & 35 & 1 & 1 & 2 & 96 \\
\hline & Total & 1 & 1 & 1 & 71 & 1 & 1 & 1 & 15 & 62 & 20 & 64 & 1 & 2 & 3 & 244 \\
\hline
\end{tabular}

100\% of 193 (Archaeology), 35\% of 401 (General Biological Science), 100\% of 408 (Ecology), 100\% of 430 (Botany), $42 \%$ of 482 (Fishery Biology), 15\% of 485 (Wildlife Refuge Management), 55\% of 486 (Wildlife Biology), 100\% of 701 (Veterinary Medical Science), 50\% of 1320 (Chemistry), and 67\% of 1530 (Statistician) position descriptions had category 1-2 content.

Of the $401,480,482,485$, and 486 positions that had category $1-2$ content in their PDs, $28 \%$ were $401,29 \%$ were $482,3 \%$ were 485 , and $39 \%$ were 486 classifications.

(2-1) Research execution - Collect data

$\chi^{2}=18.81$

Cramer's $\mathrm{V}=.29$. This measure of the strength of the association indicates a moderately strong relationship.

\begin{tabular}{|c|c|c|c|c|c|c|c|c|c|c|c|c|c|c|c|c|}
\hline \multirow{3}{*}{$\begin{array}{l}\text { Category 2-1 } \\
\text { present in PD? }\end{array}$} & & \multicolumn{15}{|c|}{ Occupational classification } \\
\hline & & 170 & 193 & 301 & 401 & 408 & 430 & 454 & 480 & 482 & 485 & 486 & 701 & 1320 & 1530 & Total \\
\hline & No & 1 & 0 & 1 & 37 & 1 & 0 & 0 & 15 & 34 & 17 & 43 & 0 & 1 & 1 & 151 \\
\hline & Yes & 0 & 1 & 0 & 34 & 0 & 1 & 1 & 0 & 28 & 3 & 21 & 1 & 1 & 2 & 93 \\
\hline & Total & 1 & 1 & 1 & 71 & 1 & 1 & 1 & 15 & 62 & 20 & 64 & 1 & 2 & 3 & 244 \\
\hline
\end{tabular}

$100 \%$ of 193 (Archaeology), $48 \%$ of 401 (General Biological Science), 100\% of 430 (Botany), 100\% of 454 (Rangeland Management), $45 \%$ of 482 (Fishery Biology), 15\% of 485 (Wildlife Refuge Management), 33\% of 486 (Wildlife Biology), 100\% of 701 (Veterinary Medical Science), $50 \%$ of 1320 (Chemistry), and $67 \%$ of 1530 (Statistician) position descriptions had category 2-1 content.

Of the $401,480,482,485$, and 486 positions that had category $2-1$ content in their PDs, $40 \%$ were $401,33 \%$ were $482,3 \%$ were 485 , and $24 \%$ were 486 classifications.

(2-5) Research execution - Conduct Inventories/Field Studies

$\chi^{2}=32.79$

Cramer's $V=.38$. This measure of the strength of the association indicates a moderately strong relationship.

\begin{tabular}{|c|c|c|c|c|c|c|c|c|c|c|c|c|c|c|c|c|}
\hline \multirow{3}{*}{$\begin{array}{l}\text { Category 2-5 } \\
\text { present in PD? }\end{array}$} & & \multicolumn{15}{|c|}{ Occupational classification } \\
\hline & & 170 & 193 & 301 & 401 & 408 & 430 & 454 & 480 & 482 & 485 & 486 & 701 & 1320 & 1530 & Total \\
\hline & No & 1 & 0 & 1 & 49 & 1 & 0 & 1 & 15 & 48 & 15 & 25 & 1 & 2 & 3 & 162 \\
\hline & Yes & 0 & 1 & 0 & 22 & 0 & 1 & 0 & 0 & 14 & 5 & 39 & 0 & 0 & 0 & 82 \\
\hline & Total & 1 & 1 & 1 & 71 & 1 & 1 & 1 & 15 & 62 & 20 & 64 & 1 & 2 & 3 & 244 \\
\hline
\end{tabular}

$100 \%$ of 193 (Archaeology), 31\% of 401 (General Biological Science), 100\% of 430 (Botany), 23\% of 482 (Fishery Biology), $25 \%$ of 485 (Wildlife Refuge Management), and $61 \%$ of 486 (Wildlife Biology) position descriptions had category 2-5 content. 
(2-6) Research execution - Conduct Monitoring

$\chi^{2}=21.06$

Cramer's $\mathrm{V}=.30$. This measure of the strength of the association indicates a moderately strong relationship.

\begin{tabular}{|c|c|c|c|c|c|c|c|c|c|c|c|c|c|c|c|c|}
\hline \multirow{3}{*}{$\begin{array}{l}\text { Category 2-6 } \\
\text { present in PD? }\end{array}$} & & \multicolumn{15}{|c|}{ Occupational classification } \\
\hline & & 170 & 193 & 301 & 401 & 408 & 430 & 454 & 480 & 482 & 485 & 486 & 701 & 1320 & 1530 & Total \\
\hline & No & 1 & 1 & 1 & 65 & 0 & 0 & 0 & 15 & 54 & 16 & 42 & 0 & 1 & 2 & 198 \\
\hline & Yes & 0 & 0 & 0 & 6 & 1 & 1 & 1 & 0 & 8 & 4 & 22 & 1 & 1 & 1 & 46 \\
\hline & Total & 1 & 1 & 1 & 71 & 1 & 1 & 1 & 15 & 62 & 20 & 64 & 1 & 2 & 3 & 244 \\
\hline
\end{tabular}

$8 \%$ of 401 (General Biological Science), 100\% of 408 (Ecology), 100\% of 430 (Botany), 100\% of 454 (Rangeland Management), $13 \%$ of 482 (Fishery Biology), 20\% of 485 (Wildlife Refuge Management), 34\% of 486 (Wildlife Biology), 100\% of 701 (Veterinary Medical Science), 50\% of 1320 (Chemistry), and 33\% of 1530 (Statistician) position descriptions had category 2-6 content.

Of the $401,480,482,485$, and 486 positions that had category 2- 6 content in their PDs, $15 \%$ were $401,20 \%$ were $482,10 \%$ were 485 , and $55 \%$ were 486 classifications.

(3-1) Research analyses - Analyzing data using qualitative of quantitative methods.

$\chi^{2}=19.10$

Cramer's $V=.29$. This measure of the strength of the association indicates a moderately strong relationship.

Occupational classification

\begin{tabular}{|c|c|c|c|c|c|c|c|c|c|c|c|c|c|c|c|c|}
\hline \multirow{4}{*}{$\begin{array}{l}\text { Category 3-1 } \\
\text { present in PD? }\end{array}$} & & 170 & 193 & 301 & 401 & 408 & 430 & 454 & 480 & 482 & 485 & 486 & 701 & 1320 & 1530 & Total \\
\hline & No & 1 & 1 & 1 & 45 & 0 & 0 & 1 & 14 & 34 & 18 & 31 & 1 & 1 & 1 & 149 \\
\hline & Yes & 0 & 0 & 0 & 26 & 1 & 1 & 0 & 1 & 28 & 2 & 33 & 0 & 1 & 2 & 95 \\
\hline & Total & 1 & 1 & 1 & 71 & 1 & 1 & 1 & 15 & 62 & 20 & 64 & 1 & 2 & 3 & 244 \\
\hline
\end{tabular}

37\% of 401 (General Biological Science), 100\% of 408 (Ecology), 100\% of 430 (Botany), 7\% of 480 (Fish and Wildlife Administration), $45 \%$ of 482 (Fishery Biology), 10\% of 485 (Wildlife Refuge Management), 52\% of 486 (Wildlife Biology), $50 \%$ of 1320 (Chemistry), and $67 \%$ of 1530 (Statistician) position descriptions had category 3-1 content.

Of the $401,480,482,485$, and 486 positions that had category $3-1$ content in their PDs, $29 \%$ were $401,1 \%$ were $480,31 \%$ were $482,2 \%$ were 485 , and $37 \%$ were 486 classifications.

(4-1) Research dissemination - Write reports from data

$\chi^{2}=13.84$

Cramer's $V=.24$. This measure of the strength of the association indicates a moderate relationship.

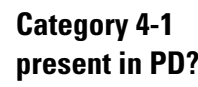

\begin{tabular}{rccccccccccccccc}
\multicolumn{1}{c}{} & $\mathbf{1 7 0}$ & $\mathbf{1 9 3}$ & $\mathbf{3 0 1}$ & $\mathbf{4 0 1}$ & $\mathbf{4 0 8}$ & $\mathbf{4 3 0}$ & $\mathbf{4 5 4}$ & $\mathbf{4 8 0}$ & $\mathbf{4 8 2}$ & $\mathbf{4 8 5}$ & $\mathbf{4 8 6}$ & $\mathbf{7 0 1}$ & $\mathbf{1 3 2 0}$ & $\mathbf{1 5 3 0}$ & Total \\
\cline { 2 - 12 } No & 1 & 1 & 1 & 49 & 1 & 0 & 1 & 15 & 48 & 20 & 46 & 1 & 2 & 1 & 187 \\
Yes & 0 & 0 & 0 & 22 & 0 & 1 & 0 & 0 & 14 & 0 & 18 & 0 & 0 & 2 & 57 \\
Total & 1 & 1 & 1 & 71 & 1 & 1 & 1 & 15 & 62 & 20 & 64 & 1 & 2 & 3 & 244
\end{tabular}

$31 \%$ of 401 (General Biological Science), 100\% of 430 (Botany), 23\% of 482 (Fishery Biology), 28\% of 486 (Wildlife Biology), and 67\% of 1530 (Statistician) position descriptions had category 4-1 content.

Of the $401,480,482,485$, and 486 positions that had category $4-1$ content in their PDs, $41 \%$ were $401,26 \%$ were 482 , and $33 \%$ were 486 classifications. 
(4-2) Research dissemination - Write articles for publication from research data

$\chi^{2}=22.84$

Cramer's $\mathrm{V}=.31$. This measure of the strength of the association indicates a moderately strong relationship.

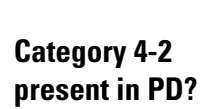

\begin{tabular}{rccccccccccccccc} 
& $\mathbf{1 7 0}$ & $\mathbf{1 9 3}$ & $\mathbf{3 0 1}$ & $\mathbf{4 0 1}$ & $\mathbf{4 0 8}$ & $\mathbf{4 3 0}$ & $\mathbf{4 5 4}$ & $\mathbf{4 8 0}$ & $\mathbf{4 8 2}$ & $\mathbf{4 8 5}$ & $\mathbf{4 8 6}$ & $\mathbf{7 0 1}$ & $\mathbf{1 3 2 0}$ & $\mathbf{1 5 3 0}$ & Total \\
\cline { 2 - 13 } & 1 & 1 & 1 & 70 & 0 & 0 & 1 & 15 & 55 & 20 & 49 & 1 & 1 & 1 & 216 \\
Yes & 0 & 0 & 0 & 1 & 1 & 1 & 0 & 0 & 7 & 0 & 15 & 0 & 1 & 2 & 28 \\
Total & 1 & 1 & 1 & 71 & 1 & 1 & 1 & 15 & 62 & 20 & 64 & 1 & 2 & 3 & 244
\end{tabular}

$1 \%$ of 401 (General Biological Science), $100 \%$ of 408 (Ecology), 100\% of 430 (Botany), 11\% of 482 (Fishery Biology), $23 \%$ of 486 (Wildife Biology), $50 \%$ of 1320 (Chemistry) and $67 \%$ of 1530 (Statistician) position descriptions had category 4-2 content.

Of the $401,480,482,485$, and 486 positions that had category $4-2$ content in their PDs, $4 \%$ were $401,30 \%$ were 482 , and $65 \%$ were 486 classifications.

(5-4) Research application - Develop new techniques/technologies/methods for research or analysis.

$\chi^{2}=22.72$

Cramer's $\mathrm{V}=.31$. This measure of the strength of the association indicates a moderately strong relationship.

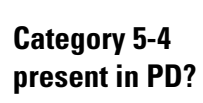

\begin{tabular}{|c|c|c|c|c|c|c|c|c|c|c|c|c|c|c|c|}
\hline & \multicolumn{15}{|c|}{ Occupational classification } \\
\hline & 170 & 193 & 301 & 401 & 408 & 430 & 454 & 480 & 482 & 485 & 486 & 701 & 1320 & 1530 & Total \\
\hline No & 1 & 1 & 1 & 69 & 1 & 1 & 1 & 15 & 59 & 20 & 50 & 1 & 2 & 1 & 223 \\
\hline Yes & 0 & 0 & 0 & 2 & 0 & 0 & 0 & 0 & 3 & 0 & 14 & 0 & 0 & 2 & 21 \\
\hline Total & 1 & 1 & 1 & 71 & 1 & 1 & 1 & 15 & 62 & 20 & 64 & 1 & 2 & 3 & 244 \\
\hline
\end{tabular}

$3 \%$ of 401 (General Biological Science), $5 \%$ of 482 (Fishery Biology), 22\% of 486 (Wildlife Biology), and $67 \%$ of 1530 (Statistician) position descriptions had category 5-4 content.

Of the $401,480,482,485$, and 486 positions that had category $5-4$ content in their PDs, $11 \%$ were $401,16 \%$ were 482 , and $73 \%$ were 486 classifications.

(6-1) Research collaboration - Collaborate with non-FWS personnel on research projects

$\chi^{2}=11.75$

Cramer's $\mathrm{V}=.23$. This measure of the strength of the association indicates a moderate relationship.

Occupational classification

\begin{tabular}{|c|c|c|c|c|c|c|c|c|c|c|c|c|c|c|c|c|}
\hline Category 6-1 & & 170 & 193 & 301 & 401 & 408 & 430 & 454 & 480 & 482 & 485 & 486 & 701 & 1320 & 1530 & Total \\
\hline nt in PD? & No & 0 & 0 & 1 & 56 & 0 & 0 & 1 & 13 & 44 & 10 & 38 & 0 & 1 & 2 & 166 \\
\hline & Yes & 1 & 1 & 0 & 15 & 1 & 1 & 0 & 2 & 18 & 10 & 26 & 1 & 1 & 1 & 78 \\
\hline & Total & 1 & 1 & 1 & 71 & 1 & 1 & 1 & 15 & 62 & 20 & 64 & 1 & 2 & 3 & 244 \\
\hline
\end{tabular}

$100 \%$ of 170 (History), 100\% of 193 (Archaeology), 21\% of 401 (General Biological Science), 100\% of 430 (Botany), 13\% of 480 (Fish and Wildlife Administration), 29\% of 482 (Fishery Biology), 50\% of 485 (Wildlife Refuge Management), $41 \%$ of 486 (Wildlife Biology), $100 \%$ of 701 (Veterinary Medical Science), 50\% of 1320 (Chemistry), and 33\% of 1530 (Statistician) position descriptions had category 6-1 content.

Of the $401,480,482,485$, and 486 positions that had category $6-1$ content in their PDs, $21 \%$ were $401,3 \%$ were $480,25 \%$ were $482,14 \%$ were 485 , and $37 \%$ were 486 classifications. 
(7-1) Knowledge/skill/ability required - Statistical data analysis

$\chi^{2}=44.16$

Cramer's $V=.44$. This measure of the strength of the association indicates a strong relationship.

\section{Category 7-1 present in PD?}

\section{Occupational classification}

\begin{tabular}{|c|c|c|c|c|c|c|c|c|c|c|c|c|c|c|c|}
\hline & 170 & 193 & 301 & 401 & 408 & 430 & 454 & 480 & 482 & 485 & 486 & 701 & 1320 & 1530 & Total \\
\hline No & 1 & 1 & 1 & 43 & 1 & 1 & 0 & 14 & 44 & 17 & 17 & 0 & 0 & 0 & 140 \\
\hline Yes & 0 & 0 & 0 & 28 & 0 & 0 & 1 & 1 & 18 & 3 & 47 & 1 & 2 & 3 & 104 \\
\hline Total & 1 & 1 & 1 & 71 & 1 & 1 & 1 & 15 & 62 & 20 & 64 & 1 & 2 & 3 & 244 \\
\hline
\end{tabular}

$39 \%$ of 401 (General Biological Science), 100\% of 454 (Rangeland Management), $7 \%$ of 480 (Fish and Wildlife Administration), $29 \%$ of 482 (Fishery Biology), 15\% of 485 (Wildlife Refuge Management), 73\% of 486 (Wildlife Biology), 100\% of 701 (Veterinary Medical Science), $100 \%$ of 1320 (Chemistry), and $100 \%$ of 1530 (Statistician) position descriptions had category 7-1 content.

Of the $401,480,482,485$, and 486 positions that had category $7-1$ content in their PDs, $29 \%$ were $401,1 \%$ were $480,19 \%$ were $482,3 \%$ were 485 , and $48 \%$ were 486 classifications.

(7-2) Knowledge/skill/ability required - Research methods

$\chi^{2}=42.16$

Cramer's $\mathrm{V}=.43$. This measure of the strength of the association indicates a strong relationship.

Occupational classification

\begin{tabular}{|c|c|c|c|c|c|c|c|c|c|c|c|c|c|c|c|c|}
\hline \multirow{4}{*}{$\begin{array}{l}\text { Category 7-2 } \\
\text { present in PD? }\end{array}$} & & 170 & 193 & 301 & 401 & 408 & 430 & 454 & 480 & 482 & 485 & 486 & 701 & 1320 & 1530 & Total \\
\hline & No & 0 & 1 & 1 & 32 & 0 & 0 & 0 & 14 & 39 & 19 & 19 & 0 & 1 & 1 & 127 \\
\hline & Yes & 1 & 0 & 0 & 39 & 1 & 1 & 1 & 1 & 23 & 1 & 45 & 1 & 1 & 2 & 117 \\
\hline & Total & 1 & 1 & 1 & 71 & 1 & 1 & 1 & 15 & 62 & 20 & 64 & 1 & 2 & 3 & 244 \\
\hline
\end{tabular}

$100 \%$ of 170 (History), 55\% of 401 (General Biological Science), 100\% of 408 (Ecology), 100\% of 430 (Botany), 100\% of 454 (Rangeland Management), $7 \%$ of 480 (Fish and Wildlife Administration), 37\% of 482 (Fishery Biology), 5\% of 485 (Wildlife Refuge Management), 70\% of 486 (Wildlife Biology), 100\% of 701 (Veterinary Medical Science), 50\% of 1320 (Chemistry), and 67\% of 1530 (Statistician) position descriptions had category $7-2$ content.

Of the $401,480,482,485$, and 486 positions that had category $7-2$ content in their PDs, $36 \%$ were $401,1 \%$ were $480,21 \%$ were $482,1 \%$ were 485 , and $41 \%$ were 486 classifications 


\section{Frequencies}

Number of position descriptions coded $=244$

\begin{tabular}{lcc}
\hline Coding category & Present in PD & Not present in PD \\
\hline (1-1) Research planning - Develop question & $4(2)^{\mathrm{a}}$ & $240(98)^{\mathrm{a}}$ \\
(1-2) Research planning - Design study & $96(39)$ & $148(61)$ \\
(1-3) Research planning - Write proposal & $12(5)$ & $232(95)$ \\
(1-4) Research planning - Develop research program & $49(20)$ & $195(80)$ \\
(2-1) Research execution - Collect data & $93(38)$ & $151(62)$ \\
(2-2) Research execution - Database management & $29(12)$ & $215(88)$ \\
(2-3) Research execution - Conduct surveys & $2(1)$ & $242(99)$ \\
(2-4) Research execution - Conduct studies/experiments & $11(5)$ & $233(96)$ \\
(2-5) Research execution - Conduct inventories & $82(34)$ & $162(66)$ \\
(2-6) Research execution - Conduct monitoring & $46(19)$ & $198(81)$ \\
(2-7) Research execution - Conduct literature review & $11(5)$ & $233(96)$ \\
(3-1) Research analyses - Analyze data & $95(39)$ & $149(61)$ \\
(4-1) Research dissemination - Write reports & $57(23)$ & $187(77)$ \\
(4-2) Research dissemination - Publication & $28(12)$ & $216(89)$ \\
(4-3) Research dissemination - Presentation & $21(9)$ & $223(91)$ \\
(5-1) Research application - Management actions & $103(42)$ & $141(58)$ \\
(5-2) Research application - Policy makers & $9(4)$ & $235(96)$ \\
(5-3) Research application - Decision documents & $7(3)$ & $237(97)$ \\
(5-4) Research application - New techniques & $21(9)$ & $223(91)$ \\
(6-1) Research collaboration - Non-FWS & $78(32)$ & $166(68)$ \\
(6-2) Research collaboration - Supervision & $59(24)$ & $185(76)$ \\
(6-3) Research collaboration - Identify funding & $3(1)$ & $241(99)$ \\
(6-4) Research collaboration - Write funding proposal & $6(3)$ & $238(98)$ \\
(7-1) Knowledge/skill/ability required - Data analysis & $104(43)$ & $140(57)$ \\
(7-2) Knowledge/skill/ability required - Research methods & $117(48)$ & $127(52)$ \\
(7-3) Knowledge/skill/ability required - Statistical software & $27(11)$ & $217(89)$ \\
(7-4) Knowledge/skill/ability required - Document preparation & $58(24)$ & $186(76)$ \\
\hline
\end{tabular}

${ }^{\mathrm{a}}$ Percentages in parentheses. 


\section{Region 1}

\section{Intercoder Agreement}

\begin{tabular}{|c|c|c|c|c|}
\hline \multirow[b]{2}{*}{ Variable } & \multicolumn{2}{|c|}{$\begin{array}{c}\text { Original data } \\
\% \text { agreement }=89 \%\end{array}$} & \multicolumn{2}{|c|}{$\begin{array}{c}\text { Consensus data } \\
\% \text { agreement }=91 \%\end{array}$} \\
\hline & Kappa & Significance & Kappa & Significance \\
\hline (1-1) Planning - Research question & & - & & - \\
\hline (1-2) Planning - Design & $.81^{\mathrm{a}}$ & .00 & $.81^{\mathrm{a}}$ & .00 \\
\hline (1-3) Planning - Write proposal & & - & & - \\
\hline (1-4) Planning - Develop program & $.38^{\mathrm{a}}$ & .00 & $.38^{\mathrm{a}}$ & .00 \\
\hline (2-1) Execution - Data collection & $.56^{\mathrm{a}}$ & .00 & $.61^{\mathrm{a}}$ & .00 \\
\hline (2-2) Execution - Manage data & $.45^{\mathrm{a}}$ & .00 & $.45^{\mathrm{a}}$ & .00 \\
\hline (2-3) Execution - Survey & & - & & - \\
\hline (2-4) Execution - Study & .13 & .38 & .22 & .14 \\
\hline (2-5) Execution - Inventory & $.72^{\mathrm{a}}$ & .00 & $.82^{\mathrm{a}}$ & .00 \\
\hline (2-6) Execution - Monitoring & $.56^{\mathrm{a}}$ & .00 & $.61^{\mathrm{a}}$ & .00 \\
\hline (2-7) Execution - Literature review & $.38^{\mathrm{a}}$ & .00 & $.48^{\mathrm{a}}$ & .00 \\
\hline (3) Analyses & $.70^{\mathrm{a}}$ & .00 & $.76^{\mathrm{a}}$ & .00 \\
\hline (4-1) Dissemination - Reports & $.57^{\mathrm{a}}$ & .00 & $.67^{\mathrm{a}}$ & .00 \\
\hline (4-2) Dissemination - Publication & $.72^{\mathrm{a}}$ & .00 & $.72^{\mathrm{a}}$ & .00 \\
\hline (4-3) Dissemination - Presentation & $.85^{\mathrm{a}}$ & .00 & $.85^{\mathrm{a}}$ & .00 \\
\hline (5-1) Application - Management & $.39^{\mathrm{a}}$ & .01 & $.81^{\mathrm{a}}$ & .00 \\
\hline (5-2) Application - Policy makers & $.30^{\mathrm{a}}$ & .01 & $.38^{\mathrm{a}}$ & .00 \\
\hline (5-3) Application - Decision documents & -.03 & .82 & -.02 & .88 \\
\hline (5-4) Application - New approaches & $.31^{\mathrm{a}}$ & .01 & $.38^{\mathrm{a}}$ & .00 \\
\hline (6-1) Collaboration - Non-FWS & $.52^{\mathrm{a}}$ & .00 & $.66^{\mathrm{a}}$ & .00 \\
\hline (6-2) Collaboration - Supervision & .24 & .10 & $.34^{\mathrm{a}}$ & .01 \\
\hline (6-3) Collaboration - Funding & & - & $\mathrm{b}$ & - \\
\hline (6-4) Collaboration - Grants & b & - & b & - \\
\hline (7-1) KSA - Data analysis & $.91^{\mathrm{a}}$ & .00 & $.91^{\mathrm{a}}$ & .00 \\
\hline (7-2) KSA - Methods & $.86^{\mathrm{a}}$ & .00 & $.86^{\mathrm{a}}$ & .00 \\
\hline (7-3) KSA - Software & $.90^{\mathrm{a}}$ & .00 & $.90^{\mathrm{a}}$ & .00 \\
\hline (7-4) KSA - Document & $.38^{\mathrm{a}}$ & .00 & $.62^{\mathrm{a}}$ & .00 \\
\hline
\end{tabular}

a Significant at $p<.05$

${ }^{\mathrm{b}}$ Kappa is not computed when at least one variable in the 2-way table is a constant. 


\section{Region 1}

\section{Latent Content Analysis}

Total number of position descriptions (PDs) coded for Region $1=43$

Number of PDs from published individuals $=22$

Number of PDs from non published individuals $=21$

Percentages are rounded and may not total 100 .

\section{Publication Status}

Each coding category was analyzed using a Chi-square, Fisher's exact test when necessary due to sparseness, to determine if the category related to whether or not a person had published. Significant (at $p<.05)$ results were found for the following categories:

(7-2) Knowledge/skill/ability required - Research methods

$\chi^{2}=5.22$

$p h i=.35$. This measure of the strength of the association indicates a moderately strong relationship.

Category 7-2 present in PD?

\begin{tabular}{|c|c|c|c|}
\hline & \multicolumn{3}{|c|}{ Publication status } \\
\hline & No & Yes & Total \\
\hline No & 14 & 7 & 21 \\
\hline Yes & 7 & 15 & 22 \\
\hline Total & 21 & 22 & 43 \\
\hline
\end{tabular}

Of the people who had published, $68 \%$ of them had category 7-2 content in their PDs.

Of the people who had category 7-2 content in their PDs, $68 \%$ of them had published. 
Even when using only the GS levels with the highest numbers of PDs, there was still too much sparseness in the data to allow for analyses at the regional level. The frequencies are provided for all content categories.

\begin{tabular}{|c|c|c|c|c|c|c|c|c|}
\hline $\begin{array}{l}\text { Category 1-1 } \\
\text { present in PD? }\end{array}$ & $\begin{array}{r}\text { No } \\
\text { Yes }\end{array}$ & 1 & 11 & 20 & 7 & 2 & 2 & $\begin{array}{c}43 \\
0\end{array}$ \\
\hline $\begin{array}{l}\text { Category 1-2 } \\
\text { present in PD? }\end{array}$ & $\begin{array}{r}\text { No } \\
\text { Yes }\end{array}$ & 1 & $\begin{array}{l}6 \\
5\end{array}$ & $\begin{array}{c}13 \\
7\end{array}$ & $\begin{array}{l}5 \\
2\end{array}$ & 2 & 2 & $\begin{array}{l}28 \\
15\end{array}$ \\
\hline $\begin{array}{l}\text { Category 1-3 } \\
\text { present in PD? }\end{array}$ & $\begin{array}{r}\text { No } \\
\text { Yes }\end{array}$ & 1 & 11 & 20 & 7 & 2 & 2 & $\begin{array}{c}43 \\
0\end{array}$ \\
\hline $\begin{array}{l}\text { Category 1-4 } \\
\text { present in PD? }\end{array}$ & $\begin{array}{r}\text { No } \\
\text { Yes }\end{array}$ & 1 & $\begin{array}{l}9 \\
2\end{array}$ & $\begin{array}{c}17 \\
3\end{array}$ & $\begin{array}{l}6 \\
1\end{array}$ & $\begin{array}{l}1 \\
1\end{array}$ & 2 & $\begin{array}{c}36 \\
7\end{array}$ \\
\hline $\begin{array}{l}\text { Category 2-1 } \\
\text { present in PD? }\end{array}$ & $\begin{array}{r}\text { No } \\
\text { Yes }\end{array}$ & 1 & $\begin{array}{l}7 \\
4\end{array}$ & $\begin{array}{c}16 \\
4\end{array}$ & $\begin{array}{l}4 \\
3\end{array}$ & 2 & 2 & $\begin{array}{l}31 \\
12\end{array}$ \\
\hline $\begin{array}{l}\text { Category 2-2 } \\
\text { present in PD? }\end{array}$ & $\begin{array}{r}\text { No } \\
\text { Yes }\end{array}$ & 1 & $\begin{array}{l}9 \\
2\end{array}$ & $\begin{array}{c}17 \\
3\end{array}$ & 7 & 2 & $\begin{array}{l}1 \\
1\end{array}$ & $\begin{array}{c}37 \\
6\end{array}$ \\
\hline $\begin{array}{l}\text { Category 2-3 } \\
\text { present in PD? }\end{array}$ & $\begin{array}{r}\text { No } \\
\text { Yes }\end{array}$ & 1 & 11 & 20 & 7 & 2 & 2 & $\begin{array}{c}43 \\
0\end{array}$ \\
\hline $\begin{array}{l}\text { Category 2-4 } \\
\text { present in PD? }\end{array}$ & $\begin{array}{r}\text { No } \\
\text { Yes }\end{array}$ & 1 & $\begin{array}{c}10 \\
1\end{array}$ & $\begin{array}{c}19 \\
1\end{array}$ & 7 & $\begin{array}{l}1 \\
1\end{array}$ & 2 & $\begin{array}{c}40 \\
3\end{array}$ \\
\hline $\begin{array}{l}\text { Category 2-5 } \\
\text { present in PD? }\end{array}$ & $\begin{array}{r}\text { No } \\
\text { Yes }\end{array}$ & 1 & $\begin{array}{l}6 \\
5\end{array}$ & $\begin{array}{c}16 \\
4\end{array}$ & 7 & 2 & 2 & $\begin{array}{l}33 \\
10\end{array}$ \\
\hline $\begin{array}{l}\text { Category 2-6 } \\
\text { present in PD? }\end{array}$ & $\begin{array}{r}\text { No } \\
\text { Yes }\end{array}$ & 1 & $\begin{array}{l}8 \\
3\end{array}$ & $\begin{array}{c}15 \\
5\end{array}$ & 7 & 2 & 2 & $\begin{array}{c}34 \\
9\end{array}$ \\
\hline $\begin{array}{l}\text { Category 2-7 } \\
\text { present in PD? }\end{array}$ & $\begin{array}{r}\text { No } \\
\text { Yes }\end{array}$ & 1 & 11 & $\begin{array}{c}19 \\
1\end{array}$ & 7 & 2 & 2 & $\begin{array}{c}42 \\
1\end{array}$ \\
\hline $\begin{array}{l}\text { Category 3-1 } \\
\text { present in PD? }\end{array}$ & $\begin{array}{r}\text { No } \\
\text { Yes }\end{array}$ & 1 & $\begin{array}{l}6 \\
5\end{array}$ & $\begin{array}{c}14 \\
6\end{array}$ & 7 & 2 & 2 & $\begin{array}{l}31 \\
12\end{array}$ \\
\hline $\begin{array}{l}\text { Category 4-1 } \\
\text { present in PD? }\end{array}$ & $\begin{array}{r}\text { No } \\
\text { Yes }\end{array}$ & 1 & $\begin{array}{l}7 \\
4\end{array}$ & $\begin{array}{c}17 \\
3\end{array}$ & 7 & 2 & 2 & $\begin{array}{c}35 \\
8\end{array}$ \\
\hline $\begin{array}{l}\text { Category 4-2 } \\
\text { present in PD? }\end{array}$ & $\begin{array}{r}\text { No } \\
\text { Yes }\end{array}$ & 1 & $\begin{array}{l}9 \\
2\end{array}$ & $\begin{array}{c}18 \\
2\end{array}$ & 7 & 2 & 2 & $\begin{array}{c}39 \\
4\end{array}$ \\
\hline $\begin{array}{l}\text { Category 4-3 } \\
\text { present in PD? }\end{array}$ & $\begin{array}{r}\text { No } \\
\text { Yes }\end{array}$ & 1 & $\begin{array}{l}9 \\
2\end{array}$ & $\begin{array}{c}18 \\
2\end{array}$ & 7 & 2 & 2 & $\begin{array}{c}39 \\
4\end{array}$ \\
\hline $\begin{array}{l}\text { Category 5-1 } \\
\text { present in PD? }\end{array}$ & $\begin{array}{r}\text { No } \\
\text { Yes }\end{array}$ & 1 & $\begin{array}{l}6 \\
5\end{array}$ & $\begin{array}{c}11 \\
9\end{array}$ & 7 & $\begin{array}{l}1 \\
1\end{array}$ & 2 & $\begin{array}{l}27 \\
16\end{array}$ \\
\hline $\begin{array}{l}\text { Category 5-2 } \\
\text { present in PD? }\end{array}$ & $\begin{array}{r}\text { No } \\
\text { Yes }\end{array}$ & 1 & 11 & $\begin{array}{c}19 \\
1\end{array}$ & 7 & 2 & 2 & $\begin{array}{c}42 \\
1\end{array}$ \\
\hline $\begin{array}{l}\text { Category 5-3 } \\
\text { present in PD? }\end{array}$ & $\begin{array}{r}\text { No } \\
\text { Yes }\end{array}$ & 1 & 11 & $\begin{array}{c}19 \\
1\end{array}$ & 7 & 2 & 2 & $\begin{array}{c}42 \\
1\end{array}$ \\
\hline
\end{tabular}




\begin{tabular}{|c|c|c|c|c|c|c|c|c|}
\hline \multirow{3}{*}{$\begin{array}{l}\text { Category 5-4 } \\
\text { present in PD? }\end{array}$} & \multirow{3}{*}{$\begin{array}{r}\text { No } \\
\text { Yes }\end{array}$} & \multicolumn{7}{|c|}{ GS level } \\
\hline & & 9 & 11 & 12 & 13 & 14 & 15 & Total \\
\hline & & 1 & $\begin{array}{c}10 \\
1\end{array}$ & 20 & 7 & 2 & 2 & $\begin{array}{c}42 \\
1\end{array}$ \\
\hline $\begin{array}{l}\text { Category 6-1 } \\
\text { present in PD? }\end{array}$ & $\begin{array}{r}\text { No } \\
\text { Yes }\end{array}$ & 1 & $\begin{array}{l}7 \\
4\end{array}$ & $\begin{array}{c}14 \\
6\end{array}$ & $\begin{array}{l}6 \\
1\end{array}$ & 2 & 2 & $\begin{array}{l}29 \\
14\end{array}$ \\
\hline $\begin{array}{l}\text { Category 6-2 } \\
\text { present in PD? }\end{array}$ & $\begin{array}{r}\text { No } \\
\text { Yes }\end{array}$ & 1 & $\begin{array}{l}9 \\
2\end{array}$ & $\begin{array}{c}15 \\
5\end{array}$ & $\begin{array}{l}6 \\
1\end{array}$ & 2 & 2 & $\begin{array}{l}33 \\
10\end{array}$ \\
\hline $\begin{array}{l}\text { Category 6-3 } \\
\text { present in PD? }\end{array}$ & $\begin{array}{r}\text { No } \\
\text { Yes }\end{array}$ & 1 & 11 & 20 & 7 & 2 & 2 & $\begin{array}{c}43 \\
0\end{array}$ \\
\hline $\begin{array}{l}\text { Category 6-4 } \\
\text { present in PD? }\end{array}$ & $\begin{array}{r}\text { No } \\
\text { Yes }\end{array}$ & 1 & 11 & 20 & 7 & 2 & 2 & $\begin{array}{c}43 \\
0\end{array}$ \\
\hline $\begin{array}{l}\text { Category 7-1 } \\
\text { present in PD? }\end{array}$ & $\begin{array}{r}\text { No } \\
\text { Yes }\end{array}$ & 1 & $\begin{array}{l}3 \\
8\end{array}$ & $\begin{array}{c}8 \\
12\end{array}$ & 7 & $\begin{array}{l}1 \\
1\end{array}$ & 2 & $\begin{array}{l}21 \\
22\end{array}$ \\
\hline $\begin{array}{l}\text { Category 7-2 } \\
\text { present in PD? }\end{array}$ & $\begin{array}{l}\text { No } \\
\text { Yes }\end{array}$ & 1 & $\begin{array}{l}4 \\
7\end{array}$ & $\begin{array}{l}10 \\
10\end{array}$ & $\begin{array}{l}5 \\
2\end{array}$ & 2 & 2 & $\begin{array}{l}21 \\
22\end{array}$ \\
\hline $\begin{array}{l}\text { Category 7-3 } \\
\text { present in PD? }\end{array}$ & $\begin{array}{l}\text { No } \\
\text { Yes }\end{array}$ & 1 & $\begin{array}{l}9 \\
2\end{array}$ & $\begin{array}{c}18 \\
2\end{array}$ & 7 & 2 & 2 & $\begin{array}{c}38 \\
5\end{array}$ \\
\hline $\begin{array}{l}\text { Category 7-4 } \\
\text { present in PD? }\end{array}$ & $\begin{array}{r}\text { No } \\
\text { Yes }\end{array}$ & 1 & $\begin{array}{l}8 \\
3\end{array}$ & $\begin{array}{c}16 \\
4\end{array}$ & 7 & 2 & 2 & $\begin{array}{c}36 \\
7\end{array}$ \\
\hline Total in GS Level & & 1 & 11 & 20 & 7 & 2 & 2 & 43 \\
\hline
\end{tabular}


Even when using only the occupational classifications with the highest numbers of PDs, there was still too much sparseness in the data to allow for analyses at the regional level. The frequencies are provided for all content categories.

\begin{tabular}{|c|c|c|c|c|c|c|c|c|c|}
\hline & & 401 & 408 & 480 & 482 & 485 & 486 & 701 & Total \\
\hline $\begin{array}{l}\text { Category 1-1 } \\
\text { present in PD? }\end{array}$ & $\begin{array}{r}\text { No } \\
\text { Yes }\end{array}$ & 14 & 1 & 2 & 10 & 8 & 7 & 1 & $\begin{array}{c}43 \\
0\end{array}$ \\
\hline $\begin{array}{l}\text { Category 1-2 } \\
\text { present in PD? }\end{array}$ & $\begin{array}{r}\text { No } \\
\text { Yes }\end{array}$ & 14 & 1 & 2 & $\begin{array}{l}5 \\
5\end{array}$ & $\begin{array}{l}7 \\
1\end{array}$ & 7 & 1 & $\begin{array}{l}28 \\
15\end{array}$ \\
\hline $\begin{array}{l}\text { Category 1-3 } \\
\text { present in PD? }\end{array}$ & $\begin{array}{r}\text { No } \\
\text { Yes }\end{array}$ & 14 & 1 & 2 & 10 & 8 & 7 & 1 & $\begin{array}{c}43 \\
0\end{array}$ \\
\hline $\begin{array}{l}\text { Category 1-4 } \\
\text { present in PD? }\end{array}$ & $\begin{array}{r}\text { No } \\
\text { Yes }\end{array}$ & 14 & 1 & 2 & $\begin{array}{l}8 \\
2\end{array}$ & $\begin{array}{l}6 \\
2\end{array}$ & $\begin{array}{l}4 \\
3\end{array}$ & 1 & $\begin{array}{c}36 \\
7\end{array}$ \\
\hline $\begin{array}{l}\text { Category 2-1 } \\
\text { present in PD? }\end{array}$ & $\begin{array}{l}\text { No } \\
\text { Yes }\end{array}$ & $\begin{array}{c}10 \\
4\end{array}$ & 1 & 2 & $\begin{array}{l}5 \\
5\end{array}$ & 8 & $\begin{array}{l}5 \\
2\end{array}$ & 1 & $\begin{array}{l}31 \\
12\end{array}$ \\
\hline $\begin{array}{l}\text { Category 2-2 } \\
\text { present in PD? }\end{array}$ & $\begin{array}{r}\text { No } \\
\text { Yes }\end{array}$ & $\begin{array}{c}12 \\
2\end{array}$ & 1 & $\begin{array}{l}1 \\
1\end{array}$ & $\begin{array}{l}9 \\
1\end{array}$ & 8 & $\begin{array}{l}5 \\
2\end{array}$ & 1 & $\begin{array}{c}37 \\
6\end{array}$ \\
\hline $\begin{array}{l}\text { Category 2-3 } \\
\text { present in PD? }\end{array}$ & $\begin{array}{r}\text { No } \\
\text { Yes }\end{array}$ & 14 & 1 & 2 & 10 & 8 & 7 & 1 & $\begin{array}{c}43 \\
0\end{array}$ \\
\hline $\begin{array}{l}\text { Category 2-4 } \\
\text { present in PD? }\end{array}$ & $\begin{array}{r}\text { No } \\
\text { Yes }\end{array}$ & 14 & 1 & 2 & $\begin{array}{l}8 \\
2\end{array}$ & 8 & $\begin{array}{l}6 \\
1\end{array}$ & 1 & $\begin{array}{c}40 \\
3\end{array}$ \\
\hline $\begin{array}{l}\text { Category 2-5 } \\
\text { present in PD? }\end{array}$ & $\begin{array}{r}\text { No } \\
\text { Yes }\end{array}$ & $\begin{array}{c}13 \\
1\end{array}$ & 1 & 2 & 10 & $\begin{array}{l}6 \\
2\end{array}$ & 7 & 1 & $\begin{array}{l}33 \\
10\end{array}$ \\
\hline $\begin{array}{l}\text { Category 2-6 } \\
\text { present in PD? }\end{array}$ & $\begin{array}{r}\text { No } \\
\text { Yes }\end{array}$ & $\begin{array}{c}13 \\
1\end{array}$ & 1 & 2 & 10 & $\begin{array}{l}7 \\
1\end{array}$ & $\begin{array}{l}2 \\
5\end{array}$ & 1 & $\begin{array}{c}34 \\
9\end{array}$ \\
\hline $\begin{array}{l}\text { Category 2-7 } \\
\text { present in PD? }\end{array}$ & $\begin{array}{r}\text { No } \\
\text { Yes }\end{array}$ & $\begin{array}{c}13 \\
1\end{array}$ & 1 & 2 & 10 & 8 & 7 & 1 & $\begin{array}{c}42 \\
1\end{array}$ \\
\hline $\begin{array}{l}\text { Category 3-1 } \\
\text { present in PD? }\end{array}$ & $\begin{array}{r}\text { No } \\
\text { Yes }\end{array}$ & $\begin{array}{c}11 \\
3\end{array}$ & 1 & 2 & $\begin{array}{l}8 \\
2\end{array}$ & $\begin{array}{l}7 \\
1\end{array}$ & $\begin{array}{l}2 \\
5\end{array}$ & 1 & $\begin{array}{l}31 \\
12\end{array}$ \\
\hline $\begin{array}{l}\text { Category 4-1 } \\
\text { present in PD? }\end{array}$ & $\begin{array}{r}\text { No } \\
\text { Yes }\end{array}$ & $\begin{array}{c}12 \\
2\end{array}$ & 1 & 2 & $\begin{array}{l}7 \\
3\end{array}$ & 8 & $\begin{array}{l}4 \\
3\end{array}$ & 1 & $\begin{array}{c}35 \\
8\end{array}$ \\
\hline $\begin{array}{l}\text { Category 4-2 } \\
\text { present in PD? }\end{array}$ & $\begin{array}{r}\text { No } \\
\text { Yes }\end{array}$ & 14 & 1 & 2 & $\begin{array}{l}9 \\
1\end{array}$ & 8 & $\begin{array}{l}5 \\
2\end{array}$ & 1 & $\begin{array}{c}39 \\
4\end{array}$ \\
\hline $\begin{array}{l}\text { Category 4-3 } \\
\text { present in PD? }\end{array}$ & $\begin{array}{r}\text { No } \\
\text { Yes }\end{array}$ & 14 & 1 & 2 & $\begin{array}{l}9 \\
1\end{array}$ & 8 & $\begin{array}{l}5 \\
2\end{array}$ & 1 & $\begin{array}{c}39 \\
4\end{array}$ \\
\hline $\begin{array}{l}\text { Category 5-1 } \\
\text { present in PD? }\end{array}$ & $\begin{array}{r}\text { No } \\
\text { Yes }\end{array}$ & $\begin{array}{c}12 \\
2\end{array}$ & 1 & 2 & $\begin{array}{l}5 \\
5\end{array}$ & $\begin{array}{l}6 \\
2\end{array}$ & $\begin{array}{l}2 \\
5\end{array}$ & 1 & $\begin{array}{l}27 \\
16\end{array}$ \\
\hline $\begin{array}{l}\text { Category 5-2 } \\
\text { present in PD? }\end{array}$ & $\begin{array}{r}\text { No } \\
\text { Yes }\end{array}$ & 14 & 1 & 2 & 10 & $\begin{array}{l}7 \\
1\end{array}$ & 7 & 1 & $\begin{array}{c}42 \\
1\end{array}$ \\
\hline
\end{tabular}




\begin{tabular}{|c|c|c|c|c|c|c|c|c|c|}
\hline & & \multicolumn{8}{|c|}{ Occupational classification } \\
\hline & & 401 & 408 & 480 & 482 & 485 & 486 & 701 & Total \\
\hline $\begin{array}{l}\text { Category 5-3 } \\
\text { present in PD? }\end{array}$ & $\begin{array}{r}\text { No } \\
\text { Yes }\end{array}$ & $\begin{array}{c}13 \\
1\end{array}$ & 1 & 2 & 10 & 8 & 7 & 1 & $\begin{array}{c}42 \\
1\end{array}$ \\
\hline $\begin{array}{l}\text { Category 5-4 } \\
\text { present in PD? }\end{array}$ & $\begin{array}{r}\text { No } \\
\text { Yes }\end{array}$ & 14 & 1 & 2 & 10 & 8 & $\begin{array}{l}6 \\
1\end{array}$ & 1 & $\begin{array}{c}42 \\
1\end{array}$ \\
\hline $\begin{array}{l}\text { Category 6-1 } \\
\text { present in PD? }\end{array}$ & $\begin{array}{r}\text { No } \\
\text { Yes }\end{array}$ & 14 & 1 & 2 & $\begin{array}{l}5 \\
5\end{array}$ & $\begin{array}{l}4 \\
4\end{array}$ & $\begin{array}{l}4 \\
3\end{array}$ & 1 & $\begin{array}{l}29 \\
14\end{array}$ \\
\hline $\begin{array}{l}\text { Category 6-2 } \\
\text { present in PD? }\end{array}$ & $\begin{array}{r}\text { No } \\
\text { Yes }\end{array}$ & $\begin{array}{c}11 \\
3\end{array}$ & 1 & 2 & $\begin{array}{l}7 \\
3\end{array}$ & 8 & $\begin{array}{l}3 \\
4\end{array}$ & 1 & $\begin{array}{l}33 \\
10\end{array}$ \\
\hline $\begin{array}{l}\text { Category 6-3 } \\
\text { present in PD? }\end{array}$ & $\begin{array}{r}\text { No } \\
\text { Yes }\end{array}$ & 14 & 1 & 2 & 10 & 8 & 7 & 1 & $\begin{array}{c}43 \\
0\end{array}$ \\
\hline $\begin{array}{l}\text { Category 6-4 } \\
\text { present in PD? }\end{array}$ & $\begin{array}{r}\text { No } \\
\text { Yes }\end{array}$ & 14 & 1 & 2 & 10 & 8 & 7 & 1 & $\begin{array}{c}43 \\
0\end{array}$ \\
\hline $\begin{array}{l}\text { Category 7-1 } \\
\text { present in PD? }\end{array}$ & $\begin{array}{r}\text { No } \\
\text { Yes }\end{array}$ & $\begin{array}{l}7 \\
7\end{array}$ & 1 & 2 & $\begin{array}{l}6 \\
4\end{array}$ & $\begin{array}{l}5 \\
3\end{array}$ & 7 & 1 & $\begin{array}{l}21 \\
22\end{array}$ \\
\hline $\begin{array}{l}\text { Category 7-2 } \\
\text { present in PD? }\end{array}$ & $\begin{array}{r}\text { No } \\
\text { Yes }\end{array}$ & $\begin{array}{l}7 \\
7\end{array}$ & 1 & 2 & $\begin{array}{l}4 \\
6\end{array}$ & $\begin{array}{l}7 \\
1\end{array}$ & $\begin{array}{l}1 \\
6\end{array}$ & 1 & $\begin{array}{l}21 \\
22\end{array}$ \\
\hline $\begin{array}{l}\text { Category 7-3 } \\
\text { present in PD? }\end{array}$ & $\begin{array}{r}\text { No } \\
\text { Yes }\end{array}$ & $\begin{array}{c}13 \\
1\end{array}$ & 1 & 2 & $\begin{array}{l}9 \\
1\end{array}$ & 8 & $\begin{array}{l}4 \\
3\end{array}$ & 1 & $\begin{array}{c}38 \\
5\end{array}$ \\
\hline $\begin{array}{l}\text { Category 7-4 } \\
\text { present in PD? }\end{array}$ & $\begin{array}{r}\text { No } \\
\text { Yes }\end{array}$ & $\begin{array}{c}12 \\
2\end{array}$ & 1 & 2 & $\begin{array}{l}9 \\
1\end{array}$ & 8 & $\begin{array}{l}4 \\
3\end{array}$ & 1 & $\begin{array}{c}36 \\
7\end{array}$ \\
\hline $\begin{array}{l}\text { Total in Occ. } \\
\text { Class }\end{array}$ & & 14 & 1 & 2 & 10 & 8 & 7 & 1 & 43 \\
\hline
\end{tabular}




\section{Frequencies}

Number of position descriptions coded $=43$

\begin{tabular}{lcc}
\hline Coding category & Present in PD & Not present in PD \\
\hline (1-1) Research planning - Develop question & & $43(100)^{\mathrm{a}}$ \\
(1-2) Research planning - Design study & $15(35)^{\mathrm{a}}$ & $28(65)$ \\
(1-3) Research planning - Write proposal & & $43(100)$ \\
(1-4) Research planning - Develop research program & $7(16)$ & $36(84)$ \\
(2-1) Research execution - Collect data & $12(28)$ & $31(72)$ \\
(2-2) Research execution - Database management & $6(14)$ & $37(86)$ \\
(2-3) Research execution - Conduct surveys & & $43(100)$ \\
(2-4) Research execution - Conduct studies/experiments & $3(7)$ & $40(93)$ \\
(2-5) Research execution - Conduct inventories & $10(23)$ & $33(77)$ \\
(2-6) Research execution - Conduct monitoring & $9(21)$ & $34(79)$ \\
(2-7) Research execution - Conduct literature review & $1(2)$ & $42(98)$ \\
(3-1) Research analyses - Analyze data & $12(28)$ & $31(72)$ \\
(4-1) Research dissemination - Write reports & $8(19)$ & $35(81)$ \\
(4-2) Research dissemination - Publication & $4(9)$ & $39(91)$ \\
(4-3) Research dissemination - Presentation & $4(9)$ & $39(91)$ \\
(5-1) Research application - Management actions & $16(37)$ & $27(63)$ \\
(5-2) Research application - Policy makers & $1(2)$ & $42(98)$ \\
(5-3) Research application - Decision documents & $1(2)$ & $42(98)$ \\
(5-4) Research application - New techniques & $1(2)$ & $42(98)$ \\
(6-1) Research collaboration - Non-FWS & $14(33)$ & $29(67)$ \\
(6-2) Research collaboration - Supervision & $10(23)$ & $33(77)$ \\
(6-3) Research collaboration - Identify funding & & $43(100)$ \\
(6-4) Research collaboration - Write funding proposal & & $43(100)$ \\
(7-1) Knowledge/skill/ability required - Data analysis & $22(51)$ & $21(49)$ \\
(7-2) Knowledge/skill/ability required - Research methods & $22(51)$ & $21(49)$ \\
(7-3) Knowledge/skill/ability required - Statistical software & $5(12)$ & $38(88)$ \\
(7-4) Knowledge/skill/ability required - Document preparation & $7(16)$ & $36(84)$ \\
\hline
\end{tabular}

${ }^{\mathrm{a}}$ Percentages in parentheses. 


\section{Region 2}

\section{Intercoder Agreement}

\begin{tabular}{|c|c|c|c|c|}
\hline \multirow[b]{2}{*}{ Variable } & \multicolumn{2}{|c|}{$\begin{array}{c}\text { Original data } \\
\% \text { agreement }=85 \%\end{array}$} & \multicolumn{2}{|c|}{$\begin{array}{c}\text { Consensus data } \\
\% \text { agreement }=90 \%\end{array}$} \\
\hline & Kappa & Significance & Kappa & Significance \\
\hline (1-1) Planning - Research question & & - & & - \\
\hline (1-2) Planning - Design & $.42^{\mathrm{b}}$ & .02 & $.60^{\mathrm{b}}$ & .00 \\
\hline (1-3) Planning - Write proposal & & - & & - \\
\hline (1-4) Planning - Develop program & $.76^{\mathrm{b}}$ & .00 & $.84^{\mathrm{b}}$ & .00 \\
\hline (2-1) Execution - Data collection & .29 & .11 & $.48^{\mathrm{b}}$ & .01 \\
\hline (2-2) Execution - Manage data & $.43^{\mathrm{b}}$ & .02 & $.69^{\mathrm{b}}$ & .00 \\
\hline (2-3) Execution - Survey & $\mathrm{a}$ & - & $\mathrm{a}$ & - \\
\hline (2-4) Execution - Study & .25 & .12 & $.39^{\mathrm{b}}$ & .02 \\
\hline (2-5) Execution - Inventory & $.49^{\mathrm{b}}$ & .01 & $.62^{\mathrm{b}}$ & .00 \\
\hline (2-6) Execution - Monitoring & $.40^{\mathrm{b}}$ & .02 & $.74^{\mathrm{b}}$ & .00 \\
\hline (2-7) Execution - Literature review & $.61^{\mathrm{b}}$ & .00 & $.71^{\mathrm{b}}$ & .00 \\
\hline (3) Analyses & $.56^{\mathrm{b}}$ & .00 & $.75^{\mathrm{b}}$ & .00 \\
\hline (4-1) Dissemination - Reports & $.37^{\mathrm{b}}$ & .04 & $.67^{\mathrm{b}}$ & .00 \\
\hline (4-2) Dissemination - Publication & $.71^{\mathrm{b}}$ & .00 & $1.0^{\mathrm{b}}$ & .00 \\
\hline (4-3) Dissemination - Presentation & $.89^{\mathrm{b}}$ & .00 & $1.0^{\mathrm{b}}$ & .00 \\
\hline (5-1) Application - Management & $.59^{\mathrm{b}}$ & .00 & $.79^{\mathrm{b}}$ & .00 \\
\hline (5-2) Application - Policy makers & -.08 & .63 & -.05 & .74 \\
\hline (5-3) Application - Decision documents & $\mathrm{a}$ & - & $.48^{\mathrm{b}}$ & .00 \\
\hline (5-4) Application - New approaches & .26 & .15 & $.35^{\mathrm{b}}$ & .05 \\
\hline (6-1) Collaboration - Non-FWS & $.54^{\mathrm{b}}$ & .00 & $.74^{\mathrm{b}}$ & .00 \\
\hline (6-2) Collaboration - Supervision & .32 & .07 & $.61^{\mathrm{b}}$ & .00 \\
\hline (6-3) Collaboration - Funding & a & - & & - \\
\hline (6-4) Collaboration - Grants & $.67^{\mathrm{b}}$ & .00 & $.80^{\mathrm{b}}$ & .00 \\
\hline (7-1) KSA - Data analysis & $.92^{\mathrm{b}}$ & .00 & $.92^{\mathrm{b}}$ & .00 \\
\hline (7-2) KSA - Methods & $.54^{\mathrm{b}}$ & .00 & $.74^{\mathrm{b}}$ & .00 \\
\hline (7-3) KSA - Software & $.43^{\mathrm{b}}$ & .01 & $.62^{\mathrm{b}}$ & .00 \\
\hline (7-4) KSA - Document & $.67^{\mathrm{b}}$ & .00 & $.76^{\mathrm{b}}$ & .00 \\
\hline
\end{tabular}

Significant at $p<.05$

${ }^{\mathrm{b}}$ Kappa is not computed when at least one variable in the 2-way table is a constant. 


\section{Region 2}

\section{Latent Content Analysis Results}

Total number of position descriptions (PDs) coded for Region $2=31$

Number of PDs from published individuals $=15$

Number of PDs from non published individuals $=16$

Percentages are rounded and may not total 100.

\section{Publication Status}

Each coding category was analyzed using a Chi-square, Fisher's exact test when necessary due to sparseness, to determine if the category related to whether or not a person had published. Significant $($ at $p<.05)$ results were found for the following categories:

(4-3) Research dissemination - Present research in professional forums (conference, meetings, symposia, etc $\chi^{2}=5.59$

$p h i=-.43$. This measure of the strength of the association indicates a moderately strong relationship in a negative direction.

\section{Category 4-3 present in PD?}

Of the people who had published, none of them had category 4-3 content in their PDs.

Of the people who had category 4-3 content in their PDs, none of them had published.

(5-1) Research application - Use research-based information to evaluate or inform management actions

$\chi^{2}=4.29$

$p h i=.37$. This measure of the strength of the association indicates a moderately strong relationship.

\begin{tabular}{|c|c|c|c|}
\hline & \multicolumn{3}{|c|}{ Publication status } \\
\hline & No & Yes & Total \\
\hline No & 9 & 3 & 12 \\
\hline Yes & 7 & 12 & 19 \\
\hline Total & 16 & 15 & 31 \\
\hline
\end{tabular}

Of the people who had published, $80 \%$ of them had category 5-1 content in their PDs.

Of the people who had category 5-1 content in their PDs, $63 \%$ of them had published. 
GS Level

Even when using only the GS levels with the highest numbers of PDs, there was still too much sparseness in the data to allow for analyses at the regional level. The frequencies are provided for all content categories.

\begin{tabular}{|c|c|c|c|c|c|c|c|}
\hline & & & & & & & \\
\hline $\begin{array}{l}\text { Category 1-1 } \\
\text { present in PD? }\end{array}$ & $\begin{array}{r}\text { No } \\
\text { Yes }\end{array}$ & 2 & 7 & 9 & 10 & 3 & $\begin{array}{c}31 \\
0\end{array}$ \\
\hline $\begin{array}{l}\text { Category 1-2 } \\
\text { present in PD? }\end{array}$ & $\begin{array}{r}\text { No } \\
\text { Yes }\end{array}$ & 2 & $\begin{array}{l}2 \\
5\end{array}$ & $\begin{array}{l}3 \\
6\end{array}$ & $\begin{array}{l}7 \\
3\end{array}$ & $\begin{array}{l}1 \\
2\end{array}$ & $\begin{array}{l}13 \\
18\end{array}$ \\
\hline $\begin{array}{l}\text { Category 1-3 } \\
\text { present in PD? }\end{array}$ & $\begin{array}{r}\text { No } \\
\text { Yes }\end{array}$ & 2 & 7 & 9 & 10 & 3 & $\begin{array}{c}31 \\
0\end{array}$ \\
\hline $\begin{array}{l}\text { Category 1-4 } \\
\text { present in PD? }\end{array}$ & $\begin{array}{r}\text { No } \\
\text { Yes }\end{array}$ & 2 & $\begin{array}{l}5 \\
2\end{array}$ & $\begin{array}{l}6 \\
3\end{array}$ & $\begin{array}{l}6 \\
4\end{array}$ & $\begin{array}{l}2 \\
1\end{array}$ & $\begin{array}{l}21 \\
10\end{array}$ \\
\hline $\begin{array}{l}\text { Category 2-1 } \\
\text { present in PD? }\end{array}$ & $\begin{array}{r}\text { No } \\
\text { Yes }\end{array}$ & 2 & $\begin{array}{l}1 \\
6\end{array}$ & $\begin{array}{l}2 \\
7\end{array}$ & $\begin{array}{l}8 \\
2\end{array}$ & $\begin{array}{l}2 \\
1\end{array}$ & $\begin{array}{l}13 \\
18\end{array}$ \\
\hline $\begin{array}{l}\text { Category 2-2 } \\
\text { present in PD? }\end{array}$ & $\begin{array}{r}\text { No } \\
\text { Yes }\end{array}$ & 2 & $\begin{array}{l}3 \\
4\end{array}$ & $\begin{array}{l}7 \\
2\end{array}$ & $\begin{array}{l}9 \\
1\end{array}$ & $\begin{array}{l}2 \\
1\end{array}$ & $\begin{array}{c}23 \\
8\end{array}$ \\
\hline $\begin{array}{l}\text { Category 2-3 } \\
\text { present in PD? }\end{array}$ & $\begin{array}{r}\text { No } \\
\text { Yes }\end{array}$ & 2 & 7 & 9 & 10 & 3 & $\begin{array}{c}31 \\
0\end{array}$ \\
\hline $\begin{array}{l}\text { Category 2-4 } \\
\text { present in PD? }\end{array}$ & $\begin{array}{r}\text { No } \\
\text { Yes }\end{array}$ & 2 & $\begin{array}{l}5 \\
2\end{array}$ & $\begin{array}{l}6 \\
3\end{array}$ & $\begin{array}{l}8 \\
2\end{array}$ & 3 & $\begin{array}{c}24 \\
7\end{array}$ \\
\hline $\begin{array}{l}\text { Category 2-5 } \\
\text { present in PD? }\end{array}$ & $\begin{array}{r}\text { No } \\
\text { Yes }\end{array}$ & 2 & $\begin{array}{l}3 \\
4\end{array}$ & $\begin{array}{l}4 \\
5\end{array}$ & $\begin{array}{l}8 \\
2\end{array}$ & $\begin{array}{l}1 \\
2\end{array}$ & $\begin{array}{l}16 \\
15\end{array}$ \\
\hline $\begin{array}{l}\text { Category 2-6 } \\
\text { present in PD? }\end{array}$ & $\begin{array}{r}\text { No } \\
\text { Yes }\end{array}$ & 2 & $\begin{array}{l}5 \\
2\end{array}$ & $\begin{array}{l}5 \\
4\end{array}$ & $\begin{array}{l}9 \\
1\end{array}$ & 3 & $\begin{array}{c}22 \\
9\end{array}$ \\
\hline $\begin{array}{l}\text { Category 2-7 } \\
\text { present in PD? }\end{array}$ & $\begin{array}{r}\text { No } \\
\text { Yes }\end{array}$ & 2 & $\begin{array}{l}5 \\
2\end{array}$ & $\begin{array}{l}8 \\
1\end{array}$ & $\begin{array}{l}9 \\
1\end{array}$ & 3 & $\begin{array}{c}27 \\
4\end{array}$ \\
\hline $\begin{array}{l}\text { Category 3-1 } \\
\text { present in PD? }\end{array}$ & $\begin{array}{r}\text { No } \\
\text { Yes }\end{array}$ & 2 & $\begin{array}{l}1 \\
6\end{array}$ & $\begin{array}{l}3 \\
6\end{array}$ & $\begin{array}{l}8 \\
2\end{array}$ & $\begin{array}{l}1 \\
2\end{array}$ & $\begin{array}{l}13 \\
18\end{array}$ \\
\hline $\begin{array}{l}\text { Category 4-1 } \\
\text { present in PD? }\end{array}$ & $\begin{array}{r}\text { No } \\
\text { Yes }\end{array}$ & 2 & $\begin{array}{l}4 \\
3\end{array}$ & $\begin{array}{l}6 \\
3\end{array}$ & 10 & $\begin{array}{l}2 \\
1\end{array}$ & $\begin{array}{c}24 \\
7\end{array}$ \\
\hline $\begin{array}{l}\text { Category 4-2 } \\
\text { present in PD? }\end{array}$ & $\begin{array}{r}\text { No } \\
\text { Yes }\end{array}$ & 2 & $\begin{array}{l}5 \\
2\end{array}$ & $\begin{array}{l}7 \\
2\end{array}$ & 10 & 3 & $\begin{array}{c}27 \\
4\end{array}$ \\
\hline $\begin{array}{l}\text { Category 4-3 } \\
\text { present in PD? }\end{array}$ & $\begin{array}{r}\text { No } \\
\text { Yes }\end{array}$ & 2 & $\begin{array}{l}5 \\
2\end{array}$ & $\begin{array}{l}8 \\
1\end{array}$ & $\begin{array}{l}8 \\
2\end{array}$ & 3 & $\begin{array}{c}26 \\
5\end{array}$ \\
\hline $\begin{array}{l}\text { Category 5-1 } \\
\text { present in PD? }\end{array}$ & $\begin{array}{r}\text { No } \\
\text { Yes }\end{array}$ & 2 & $\begin{array}{l}2 \\
5\end{array}$ & $\begin{array}{l}3 \\
6\end{array}$ & $\begin{array}{l}6 \\
4\end{array}$ & $\begin{array}{l}1 \\
2\end{array}$ & $\begin{array}{l}12 \\
19\end{array}$ \\
\hline $\begin{array}{l}\text { Category 5-2 } \\
\text { present in PD? }\end{array}$ & $\begin{array}{r}\text { No } \\
\text { Yes }\end{array}$ & 2 & $\begin{array}{l}6 \\
1\end{array}$ & $\begin{array}{l}8 \\
1\end{array}$ & $\begin{array}{l}9 \\
1\end{array}$ & 3 & $\begin{array}{c}28 \\
3\end{array}$ \\
\hline
\end{tabular}




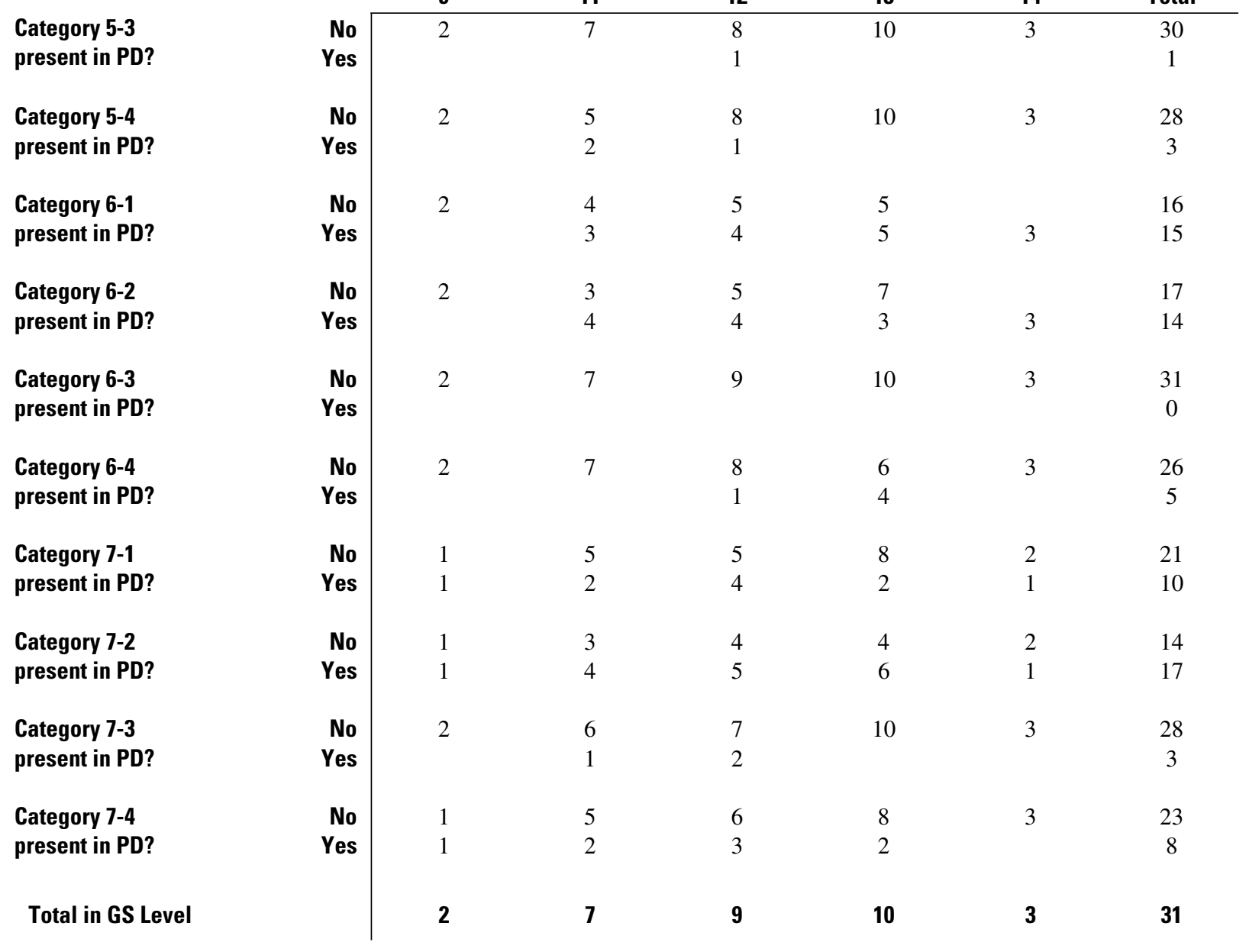


Even when using only the occupational classifications with the highest numbers of PDs, there was still too much sparseness in the data to allow for analyses at the regional level. The frequencies are provided for all content categories.

\begin{tabular}{|c|c|c|c|c|c|c|c|c|}
\hline & & & & & & & & \\
\hline $\begin{array}{l}\text { Category 1-1 } \\
\text { present in PD? }\end{array}$ & $\begin{array}{r}\text { No } \\
\text { Yes }\end{array}$ & 12 & 1 & 1 & 8 & 4 & 5 & $\begin{array}{c}31 \\
0\end{array}$ \\
\hline Category 1-2 & No & 6 & & 1 & 1 & 3 & 2 & 13 \\
\hline present in PD? & Yes & 6 & 1 & & 7 & 1 & 3 & 18 \\
\hline $\begin{array}{l}\text { Category 1-3 } \\
\text { present in PD? }\end{array}$ & $\begin{array}{r}\text { No } \\
\text { Yes }\end{array}$ & 12 & 1 & 1 & 8 & 4 & 5 & $\begin{array}{c}31 \\
0\end{array}$ \\
\hline Category 1-4 & No & 11 & & 1 & 5 & & 4 & 21 \\
\hline present in PD? & Yes & 1 & 1 & & 3 & 4 & 1 & 10 \\
\hline Category 2-1 & No & 4 & & 1 & 3 & 3 & 2 & 13 \\
\hline present in PD? & Yes & 8 & 1 & & 5 & 1 & 3 & 18 \\
\hline Category 2-2 & No & 10 & & 1 & 5 & 3 & 4 & 23 \\
\hline present in PD? & Yes & 2 & 1 & & 3 & 1 & 1 & 8 \\
\hline $\begin{array}{l}\text { Category 2-3 } \\
\text { present in PD? }\end{array}$ & $\begin{array}{r}\text { No } \\
\text { Yes }\end{array}$ & 12 & 1 & 1 & 8 & 4 & 5 & $\begin{array}{c}31 \\
0\end{array}$ \\
\hline Category 2-4 & No & 11 & & 1 & 4 & 3 & 5 & 24 \\
\hline present in PD? & Yes & 1 & 1 & & 4 & 1 & & 7 \\
\hline Category 2-5 & No & 9 & & 1 & 2 & 2 & 2 & 16 \\
\hline present in PD? & Yes & 3 & 1 & & 6 & 2 & 3 & 15 \\
\hline Category 2-6 & No & 10 & & 1 & 5 & 2 & 4 & 22 \\
\hline present in PD? & Yes & 2 & 1 & & 3 & 2 & 1 & 9 \\
\hline Category 2-7 & No & 12 & & 1 & 8 & 4 & 2 & 27 \\
\hline present in PD? & Yes & & 1 & & & & 3 & 4 \\
\hline Category 3-1 & No & 6 & & 1 & 2 & 3 & 1 & 13 \\
\hline present in PD? & Yes & 6 & 1 & & 6 & 1 & 4 & 18 \\
\hline Category 4-1 & No & 10 & & 1 & 6 & 4 & 3 & 24 \\
\hline present in PD? & Yes & 2 & 1 & & 2 & & 2 & 7 \\
\hline Category 4-2 & No & 11 & & 1 & 7 & 4 & 4 & 27 \\
\hline present in PD? & Yes & 1 & 1 & & 1 & & 1 & 4 \\
\hline Category 4-3 & No & 10 & & 1 & 7 & 4 & 4 & 26 \\
\hline present in PD? & Yes & 2 & 1 & & 1 & & 1 & 5 \\
\hline Category 5-1 & No & 3 & & 1 & 3 & 3 & 2 & 12 \\
\hline present in PD? & Yes & 9 & 1 & & 5 & 1 & 3 & 19 \\
\hline Category 5-2 & No & 11 & 1 & 1 & 7 & 4 & 4 & 28 \\
\hline present in PD? & Yes & 1 & & & 1 & & 1 & 3 \\
\hline
\end{tabular}


Category 5-3

present in PD?

Category 5-4

present in PD?

Category 6-1

present in PD?

Category 6-2

present in PD?

Category 6-3

present in PD?

Category 6-4

present in PD?

Category 7-1

present in PD?

Category 7-2

present in PD?

Category 7-3

present in PD?

Category 7-4

present in PD?

Total in Occ.

Class

Occupational classification

480

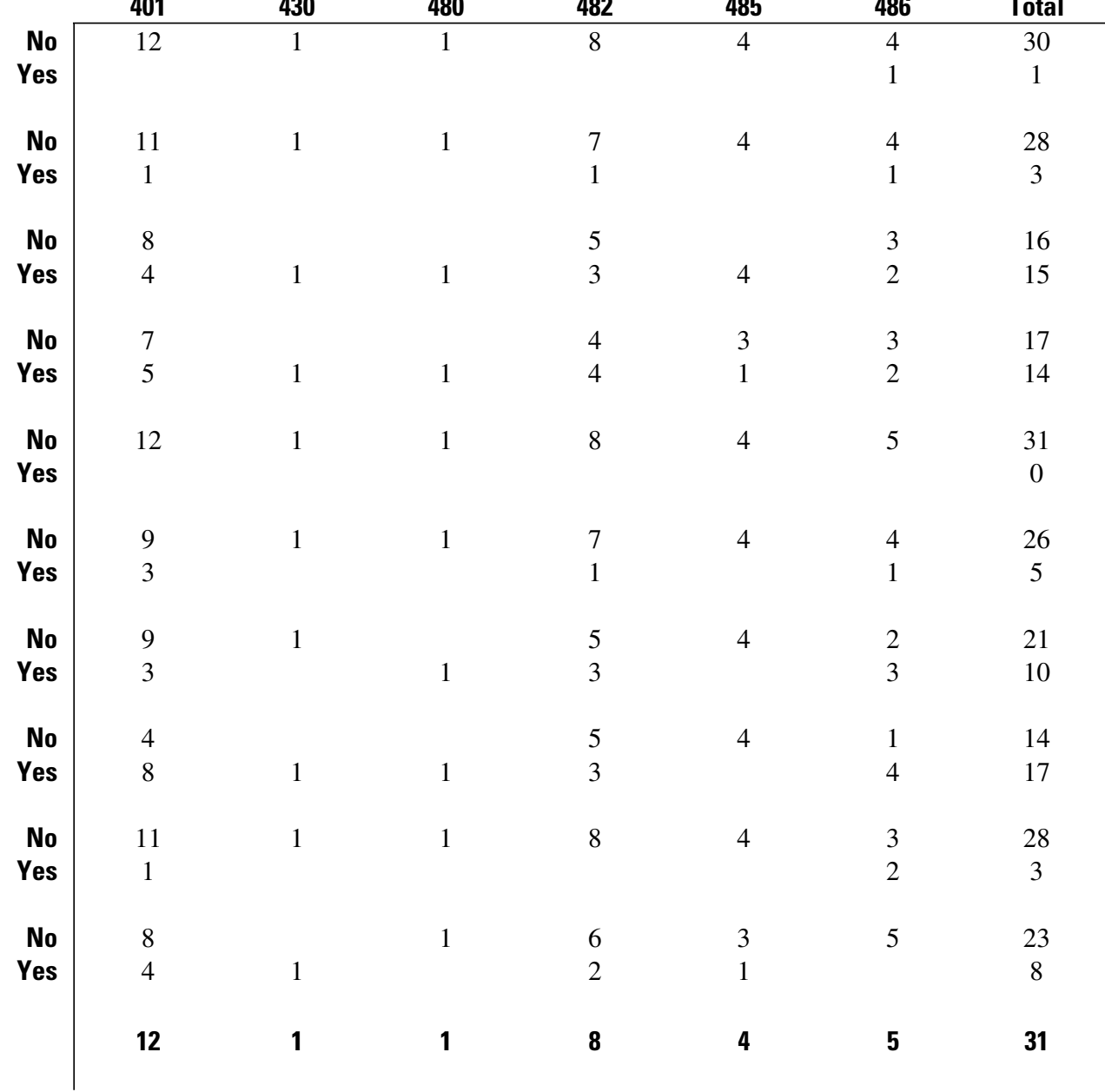




\section{Frequencies}

Number of position descriptions coded $=31$

\begin{tabular}{lcc}
\hline Coding category & Present in PD & Not present in PD \\
\hline (1-1) Research planning - Develop question & & $31(100)^{\mathrm{a}}$ \\
(1-2) Research planning - Design study & $18(58)^{\mathrm{a}}$ & $13(42)$ \\
(1-3) Research planning - Write proposal & & $31(100)$ \\
(1-4) Research planning - Develop research program & $10(32)$ & $21(68)$ \\
(2-1) Research execution - Collect data & $18(58)$ & $13(42)$ \\
(2-2) Research execution - Database management & $8(26)$ & $23(74)$ \\
(2-3) Research execution - Conduct surveys & & $31(100)$ \\
(2-4) Research execution - Conduct studies/experiments & $7(23)$ & $24(77)$ \\
(2-5) Research execution - Conduct inventories & $15(48)$ & $16(52)$ \\
(2-6) Research execution - Conduct monitoring & $9(29)$ & $22(71)$ \\
(2-7) Research execution - Conduct literature review & $4(13)$ & $27(87)$ \\
(3-1) Research analyses - Analyze data & $18(58)$ & $13(42)$ \\
(4-1) Research dissemination - Write reports & $7(23)$ & $24(77)$ \\
(4-2) Research dissemination - Publication & $4(13)$ & $27(87)$ \\
(4-3) Research dissemination - Presentation & $5(16)$ & $26(84)$ \\
(5-1) Research application - Management actions & $19(61)$ & $12(39)$ \\
(5-2) Research application - Policy makers & $3(10)$ & $28(90)$ \\
(5-3) Research application - Decision documents & $1(3)$ & $30(97)$ \\
(5-4) Research application - New techniques & $3(10)$ & $28(90)$ \\
(6-1) Research collaboration - Non-FWS & $15(48)$ & $16(52)$ \\
(6-2) Research collaboration - Supervision & $14(45)$ & $17(55)$ \\
(6-3) Research collaboration - Identify funding & & $31(100)$ \\
(6-4) Research collaboration - Write funding proposal & $5(16)$ & $26(84)$ \\
(7-1) Knowledge/skill/ability required - Data analysis & $10(32)$ & $21(68)$ \\
(7-2) Knowledge/skill/ability required - Research methods & $17(55)$ & $14(45)$ \\
(7-3) Knowledge/skill/ability required - Statistical software & $3(10)$ & $28(90)$ \\
(7-4) Knowledge/skill/ability required - Document preparation & $8(26)$ & $23(74)$ \\
\hline
\end{tabular}

${ }^{\mathrm{a}}$ Percentages in parentheses. 


\section{Region 3}

\section{Intercoder Agreement}

\begin{tabular}{|c|c|c|c|c|}
\hline \multirow[b]{2}{*}{ Variable } & \multicolumn{2}{|c|}{$\begin{array}{c}\text { Original data } \\
\% \text { agreement }=91 \%\end{array}$} & \multicolumn{2}{|c|}{$\begin{array}{c}\text { Consensus data } \\
\% \text { agreement }=96 \%\end{array}$} \\
\hline & Kappa & Significance & Kappa & Significance \\
\hline (1-1) Planning - Research question & & - & & - \\
\hline (1-2) Planning - Design & $.90^{\mathrm{a}}$ & .00 & $.90^{\mathrm{a}}$ & .00 \\
\hline (1-3) Planning - Write proposal & & - & & - \\
\hline (1-4) Planning - Develop program & $.29^{\mathrm{a}}$ & .03 & $.37^{\mathrm{a}}$ & .01 \\
\hline (2-1) Execution - Data collection & $.37^{\mathrm{a}}$ & .05 & $.49^{\mathrm{a}}$ & .01 \\
\hline (2-2) Execution - Manage data & & - & & - \\
\hline (2-3) Execution - Survey & $1.0^{\mathrm{a}}$ & .00 & $1.0^{\mathrm{a}}$ & .00 \\
\hline (2-4) Execution - Study & & - & & - \\
\hline (2-5) Execution - Inventory & $.63^{\mathrm{a}}$ & .00 & $.63^{\mathrm{a}}$ & .00 \\
\hline (2-6) Execution - Monitoring & $.37^{\mathrm{a}}$ & .01 & $.78^{\mathrm{a}}$ & .00 \\
\hline (2-7) Execution - Literature review & $\mathrm{b}$ & - & & - \\
\hline (3) Analyses & $.85^{\mathrm{a}}$ & .00 & $.93^{\mathrm{a}}$ & .00 \\
\hline (4-1) Dissemination - Reports & $.41^{\mathrm{a}}$ & .01 & $.47^{\mathrm{a}}$ & .00 \\
\hline (4-2) Dissemination - Publication & $.61^{\mathrm{a}}$ & .00 & $.61^{\mathrm{a}}$ & .00 \\
\hline (4-3) Dissemination - Presentation & $.65^{\mathrm{a}}$ & .00 & $.65^{\mathrm{a}}$ & .00 \\
\hline (5-1) Application - Management & $.43^{\mathrm{a}}$ & .02 & $.52^{\mathrm{a}}$ & .01 \\
\hline (5-2) Application - Policy makers & $\mathrm{b}$ & - & b & - \\
\hline (5-3) Application - Decision documents & b & - & b & - \\
\hline (5-4) Application - New approaches & -.04 & .85 & b & - \\
\hline (6-1) Collaboration - Non-FWS & .28 & .14 & $.44^{\mathrm{a}}$ & .02 \\
\hline (6-2) Collaboration - Supervision & .08 & .55 & $.78^{\mathrm{a}}$ & .00 \\
\hline (6-3) Collaboration - Funding & & - & & - \\
\hline (6-4) Collaboration - Grants & b & - & b & - \\
\hline (7-1) KSA - Data analysis & $.84^{\mathrm{a}}$ & .00 & $1.0^{\mathrm{a}}$ & .00 \\
\hline (7-2) KSA - Methods & $.54^{\mathrm{a}}$ & .00 & $.54^{\mathrm{a}}$ & .00 \\
\hline (7-3) KSA - Software & $.83^{\mathrm{a}}$ & .00 & $.83^{\mathrm{a}}$ & .00 \\
\hline (7-4) KSA - Document & $.81^{\mathrm{a}}$ & .00 & $.81^{\mathrm{a}}$ & .00 \\
\hline
\end{tabular}

${ }^{\mathrm{a}}$ Significant at $p<.05$

${ }^{\mathrm{b}} \mathrm{Kappa}$ is not computed when at least one variable in the 2-way table is a constant. 


\section{Region 3}

\section{Latent Content Analysis Results}

Total number of position descriptions (PDs) coded for Region $3=29$

Number of PDs from published individuals $=17$

Number of PDs from non published individuals $=12$

Percentages are rounded and may not total 100 .

\section{Publication Status}

Each coding category was analyzed using a Chi-square, Fisher's exact test when necessary due to sparseness, to determine if the category related to whether or not a person had published. Significant (at $p<.05)$ results were found for the following categories:

(3-1) Research analyses - Analyzing data using qualitative or quantitative methods.

$\chi^{2}=6.20$

$p h i=.46$. This measure of the strength of the association indicates a moderately strong relationship.

Category 3-1 present in PD?

\begin{tabular}{|c|c|c|c|}
\hline & \multicolumn{3}{|c|}{ Publication status } \\
\hline & No & Yes & Total \\
\hline No & 11 & 8 & 19 \\
\hline Yes & 1 & 9 & 10 \\
\hline Total & 12 & 17 & 29 \\
\hline
\end{tabular}

Of the people who had published, 53\% of them had category 3-1 content in their PDs.

Of the people who had category 3-1 content in their PDs, $90 \%$ of them had published. 
GS Level

Even when using only the GS levels with the highest numbers of PDs, there was still too much sparseness in the data to allow for analyses at the regional level. The frequencies are provided for all content categories.

\begin{tabular}{|c|c|c|c|c|c|c|c|c|c|}
\hline & & & & & & 13 & 14 & 15 & lotal \\
\hline $\begin{array}{l}\text { Category 1-1 } \\
\text { present in PD? }\end{array}$ & $\begin{array}{r}\text { No } \\
\text { Yes }\end{array}$ & 1 & 3 & 4 & 6 & 10 & 3 & 2 & $\begin{array}{c}29 \\
0\end{array}$ \\
\hline $\begin{array}{l}\text { Category 1-2 } \\
\text { present in PD? }\end{array}$ & $\begin{array}{l}\text { No } \\
\text { Yes }\end{array}$ & 1 & 3 & $\begin{array}{l}1 \\
3\end{array}$ & $\begin{array}{l}3 \\
3\end{array}$ & $\begin{array}{l}9 \\
1\end{array}$ & 3 & 2 & $\begin{array}{c}22 \\
7\end{array}$ \\
\hline $\begin{array}{l}\text { Category 1-3 } \\
\text { present in PD? }\end{array}$ & $\begin{array}{r}\text { No } \\
\text { Yes }\end{array}$ & 1 & 3 & 4 & 6 & 10 & 3 & 2 & $\begin{array}{c}29 \\
0\end{array}$ \\
\hline $\begin{array}{l}\text { Category 1-4 } \\
\text { present in PD? }\end{array}$ & $\begin{array}{r}\text { No } \\
\text { Yes }\end{array}$ & 1 & 3 & 4 & $\begin{array}{l}5 \\
1\end{array}$ & 10 & 3 & 2 & $\begin{array}{c}28 \\
1\end{array}$ \\
\hline $\begin{array}{l}\text { Category 2-1 } \\
\text { present in PD? }\end{array}$ & $\begin{array}{l}\text { No } \\
\text { Yes }\end{array}$ & 1 & $\begin{array}{l}1 \\
2\end{array}$ & $\begin{array}{l}2 \\
2\end{array}$ & $\begin{array}{l}2 \\
4\end{array}$ & 10 & 3 & 2 & $\begin{array}{c}20 \\
9\end{array}$ \\
\hline $\begin{array}{l}\text { Category 2-2 } \\
\text { present in PD? }\end{array}$ & $\begin{array}{r}\text { No } \\
\text { Yes }\end{array}$ & 1 & 3 & 4 & 6 & 10 & 3 & 2 & $\begin{array}{c}29 \\
0\end{array}$ \\
\hline $\begin{array}{l}\text { Category 2-3 } \\
\text { present in PD? }\end{array}$ & $\begin{array}{l}\text { No } \\
\text { Yes }\end{array}$ & 1 & 3 & 4 & $\begin{array}{l}5 \\
1\end{array}$ & 10 & 3 & 2 & $\begin{array}{c}28 \\
1\end{array}$ \\
\hline $\begin{array}{l}\text { Category 2-4 } \\
\text { present in PD? }\end{array}$ & $\begin{array}{r}\text { No } \\
\text { Yes }\end{array}$ & 1 & 3 & 4 & 6 & 10 & 3 & 2 & $\begin{array}{c}29 \\
0\end{array}$ \\
\hline $\begin{array}{l}\text { Category 2-5 } \\
\text { present in PD? }\end{array}$ & $\begin{array}{r}\text { No } \\
\text { Yes }\end{array}$ & 1 & $\begin{array}{l}2 \\
1\end{array}$ & 4 & $\begin{array}{l}5 \\
1\end{array}$ & 10 & 3 & 2 & $\begin{array}{c}27 \\
2\end{array}$ \\
\hline $\begin{array}{l}\text { Category 2-6 } \\
\text { present in PD? }\end{array}$ & $\begin{array}{r}\text { No } \\
\text { Yes }\end{array}$ & 1 & 3 & 4 & $\begin{array}{l}4 \\
2\end{array}$ & 10 & 3 & 2 & $\begin{array}{c}27 \\
2\end{array}$ \\
\hline $\begin{array}{l}\text { Category 2-7 } \\
\text { present in PD? }\end{array}$ & $\begin{array}{l}\text { No } \\
\text { Yes }\end{array}$ & 1 & 3 & 4 & 6 & 10 & 3 & 2 & $\begin{array}{c}29 \\
0\end{array}$ \\
\hline $\begin{array}{l}\text { Category 3-1 } \\
\text { present in PD? }\end{array}$ & $\begin{array}{l}\text { No } \\
\text { Yes }\end{array}$ & 1 & $\begin{array}{l}2 \\
1\end{array}$ & 4 & $\begin{array}{l}3 \\
3\end{array}$ & $\begin{array}{l}8 \\
2\end{array}$ & 3 & 2 & $\begin{array}{l}19 \\
10\end{array}$ \\
\hline $\begin{array}{l}\text { Category 4-1 } \\
\text { present in PD? }\end{array}$ & $\begin{array}{r}\text { No } \\
\text { Yes }\end{array}$ & 1 & $\begin{array}{l}2 \\
1\end{array}$ & $\begin{array}{l}3 \\
1\end{array}$ & 6 & $\begin{array}{l}9 \\
1\end{array}$ & 3 & 2 & $\begin{array}{c}26 \\
3\end{array}$ \\
\hline $\begin{array}{l}\text { Category 4-2 } \\
\text { present in PD? }\end{array}$ & $\begin{array}{l}\text { No } \\
\text { Yes }\end{array}$ & 1 & 3 & 4 & $\begin{array}{l}4 \\
2\end{array}$ & $\begin{array}{l}9 \\
1\end{array}$ & 3 & 2 & $\begin{array}{c}26 \\
3\end{array}$ \\
\hline $\begin{array}{l}\text { Category 4-3 } \\
\text { present in PD? }\end{array}$ & $\begin{array}{r}\text { No } \\
\text { Yes }\end{array}$ & 1 & 3 & 4 & $\begin{array}{l}5 \\
1\end{array}$ & 10 & 3 & 2 & $\begin{array}{c}28 \\
1\end{array}$ \\
\hline $\begin{array}{l}\text { Category 5-1 } \\
\text { present in PD? }\end{array}$ & $\begin{array}{r}\text { No } \\
\text { Yes }\end{array}$ & 1 & $\begin{array}{l}1 \\
2\end{array}$ & $\begin{array}{l}1 \\
3\end{array}$ & $\begin{array}{l}3 \\
3\end{array}$ & $\begin{array}{l}5 \\
5\end{array}$ & 3 & $\begin{array}{l}1 \\
1\end{array}$ & $\begin{array}{l}15 \\
14\end{array}$ \\
\hline $\begin{array}{l}\text { Category 5-2 } \\
\text { present in PD? }\end{array}$ & $\begin{array}{r}\text { No } \\
\text { Yes }\end{array}$ & 1 & 3 & 4 & 6 & 10 & 3 & 2 & $\begin{array}{c}29 \\
0\end{array}$ \\
\hline $\begin{array}{l}\text { Category 5-3 } \\
\text { present in PD? }\end{array}$ & $\begin{array}{r}\text { No } \\
\text { Yes }\end{array}$ & 1 & 3 & 4 & 6 & 10 & 3 & 2 & $\begin{array}{c}29 \\
0\end{array}$ \\
\hline
\end{tabular}


present in PD?

Category 6-1

present in PD?

Category 6-2

present in PD?

Category 6-3

present in PD?

Category 6-4

present in PD?

Category 7-1

present in PD?

Category 7-2

present in PD?

Category 7-3

present in PD?

Category 7-4

present in PD?

Total in GS

Level

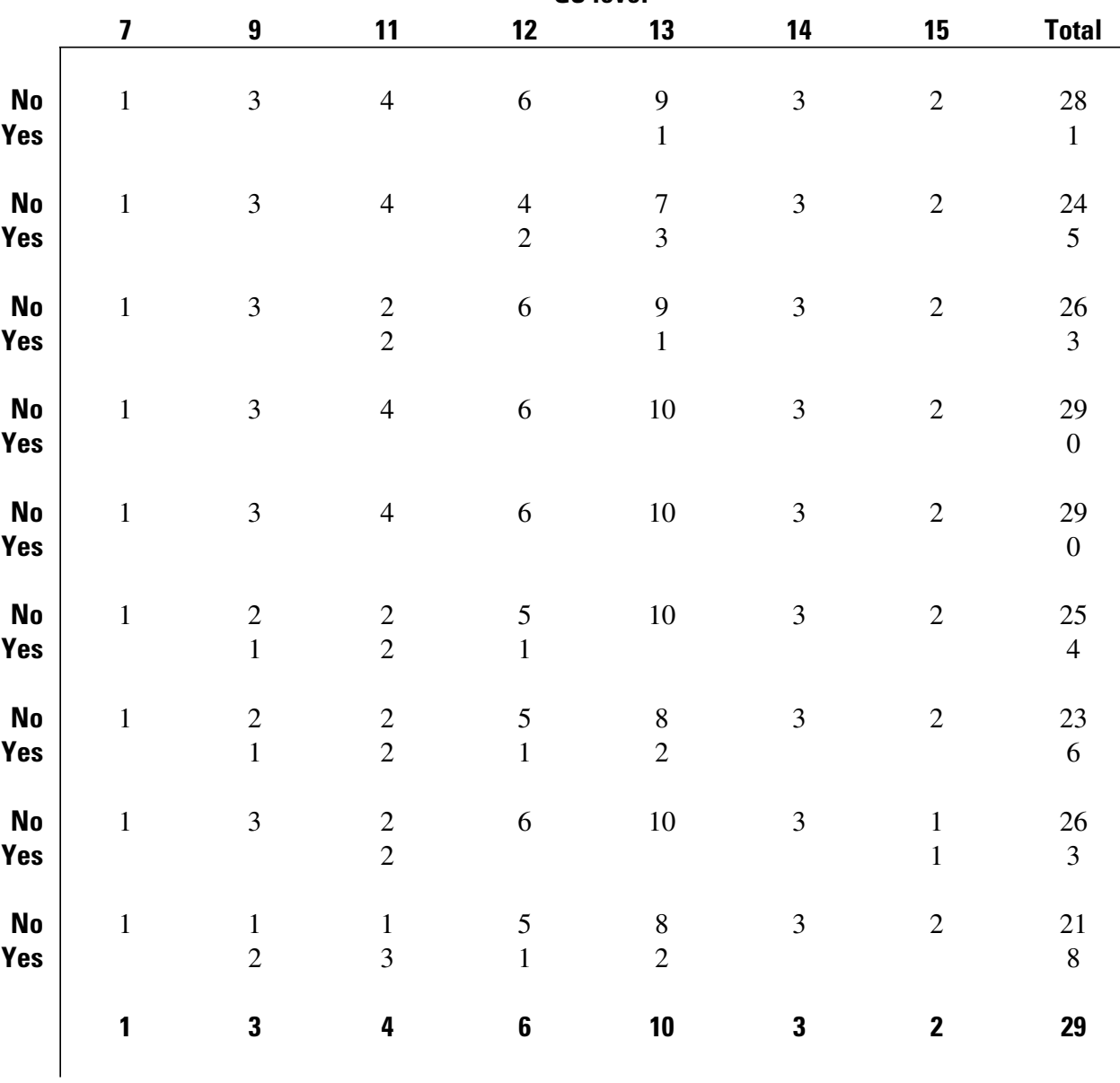


Even when using only the occupational classifications with the highest numbers of PDs, there was still too much sparseness in the data to allow for analyses at the regional level. The frequencies are provided for all content categories.

\begin{tabular}{|c|c|c|c|c|c|c|c|c|}
\hline \multirow[b]{2}{*}{$\begin{array}{l}\text { Category 1-1 } \\
\text { present in PD? }\end{array}$} & \multirow[b]{2}{*}{$\begin{array}{r}\text { No } \\
\text { Yes }\end{array}$} & \multirow{2}{*}{$\begin{array}{c}401 \\
5\end{array}$} & \multirow{2}{*}{$\begin{array}{c}480 \\
3\end{array}$} & \multirow{2}{*}{$\begin{array}{c}\mathbf{4 8 2} \\
16\end{array}$} & \multirow{2}{*}{$\begin{array}{c}\mathbf{4 8 5} \\
3\end{array}$} & \multirow{2}{*}{$\begin{array}{c}\mathbf{4 8 0} \\
1\end{array}$} & \multirow{2}{*}{$\frac{\mid \text { ISZU }}{1}$} & \multirow[b]{2}{*}{$\begin{array}{c}10 t a 1 \\
29 \\
0\end{array}$} \\
\hline & & & & & & & & \\
\hline $\begin{array}{l}\text { Category 1-2 } \\
\text { present in PD? }\end{array}$ & $\begin{array}{l}\text { No } \\
\text { Yes }\end{array}$ & $\begin{array}{l}4 \\
1\end{array}$ & 3 & $\begin{array}{c}13 \\
3\end{array}$ & $\begin{array}{l}2 \\
1\end{array}$ & 1 & 1 & $\begin{array}{c}22 \\
7\end{array}$ \\
\hline $\begin{array}{l}\text { Category 1-3 } \\
\text { present in PD? }\end{array}$ & $\begin{array}{l}\text { No } \\
\text { Yes }\end{array}$ & 5 & 3 & 16 & 3 & 1 & 1 & $\begin{array}{c}29 \\
0\end{array}$ \\
\hline $\begin{array}{l}\text { Category 1-4 } \\
\text { present in PD? }\end{array}$ & $\begin{array}{r}\text { No } \\
\text { Yes }\end{array}$ & 5 & 3 & 16 & 3 & 1 & 1 & $\begin{array}{c}28 \\
1\end{array}$ \\
\hline $\begin{array}{l}\text { Category 2-1 } \\
\text { present in PD? }\end{array}$ & $\begin{array}{l}\text { No } \\
\text { Yes }\end{array}$ & 5 & 3 & $\begin{array}{c}10 \\
6\end{array}$ & $\begin{array}{l}2 \\
1\end{array}$ & 1 & 1 & $\begin{array}{c}20 \\
9\end{array}$ \\
\hline $\begin{array}{l}\text { Category 2-2 } \\
\text { present in PD? }\end{array}$ & $\begin{array}{r}\text { No } \\
\text { Yes }\end{array}$ & 5 & 3 & 16 & 3 & 1 & 1 & $\begin{array}{c}29 \\
0\end{array}$ \\
\hline $\begin{array}{l}\text { Category 2-3 } \\
\text { present in PD? }\end{array}$ & $\begin{array}{r}\text { No } \\
\text { Yes }\end{array}$ & 5 & 3 & 16 & $\begin{array}{l}2 \\
1\end{array}$ & 1 & 1 & $\begin{array}{c}28 \\
1\end{array}$ \\
\hline $\begin{array}{l}\text { Category 2-4 } \\
\text { present in PD? }\end{array}$ & $\begin{array}{r}\text { No } \\
\text { Yes }\end{array}$ & 5 & 3 & 16 & 3 & 1 & 1 & $\begin{array}{c}29 \\
0\end{array}$ \\
\hline $\begin{array}{l}\text { Category 2-5 } \\
\text { present in PD? }\end{array}$ & $\begin{array}{r}\text { No } \\
\text { Yes }\end{array}$ & 5 & 3 & $\begin{array}{c}15 \\
1\end{array}$ & $\begin{array}{l}2 \\
1\end{array}$ & 1 & 1 & $\begin{array}{c}27 \\
2\end{array}$ \\
\hline $\begin{array}{l}\text { Category 2-6 } \\
\text { present in PD? }\end{array}$ & $\begin{array}{l}\text { No } \\
\text { Yes }\end{array}$ & 5 & 3 & $\begin{array}{c}15 \\
1\end{array}$ & 3 & 1 & 1 & $\begin{array}{c}27 \\
2\end{array}$ \\
\hline $\begin{array}{l}\text { Category 2-7 } \\
\text { present in PD? }\end{array}$ & $\begin{array}{r}\text { No } \\
\text { Yes }\end{array}$ & 5 & 3 & 16 & 3 & 1 & 1 & $\begin{array}{c}29 \\
0\end{array}$ \\
\hline $\begin{array}{l}\text { Category 3-1 } \\
\text { present in PD? }\end{array}$ & $\begin{array}{l}\text { No } \\
\text { Yes }\end{array}$ & 5 & 3 & $\begin{array}{l}8 \\
8\end{array}$ & 3 & 1 & 1 & $\begin{array}{l}19 \\
10\end{array}$ \\
\hline $\begin{array}{l}\text { Category 4-1 } \\
\text { present in PD? }\end{array}$ & $\begin{array}{r}\text { No } \\
\text { Yes }\end{array}$ & 5 & 3 & $\begin{array}{c}13 \\
3\end{array}$ & 3 & 1 & 1 & $\begin{array}{c}26 \\
3\end{array}$ \\
\hline $\begin{array}{l}\text { Category 4-2 } \\
\text { present in PD? }\end{array}$ & $\begin{array}{r}\text { No } \\
\text { Yes }\end{array}$ & 5 & 3 & $\begin{array}{c}14 \\
2\end{array}$ & 3 & 1 & 1 & $\begin{array}{c}26 \\
3\end{array}$ \\
\hline $\begin{array}{l}\text { Category 4-3 } \\
\text { present in PD? }\end{array}$ & $\begin{array}{r}\text { No } \\
\text { Yes }\end{array}$ & 5 & 3 & 16 & 3 & 1 & 1 & $\begin{array}{c}28 \\
1\end{array}$ \\
\hline $\begin{array}{l}\text { Category 5-1 } \\
\text { present in PD? }\end{array}$ & $\begin{array}{r}\text { No } \\
\text { Yes }\end{array}$ & $\begin{array}{l}3 \\
2\end{array}$ & $\begin{array}{l}2 \\
1\end{array}$ & $\begin{array}{l}9 \\
7\end{array}$ & $\begin{array}{l}1 \\
2\end{array}$ & 1 & 1 & $\begin{array}{l}15 \\
14\end{array}$ \\
\hline $\begin{array}{l}\text { Category 5-2 } \\
\text { present in PD? }\end{array}$ & $\begin{array}{r}\text { No } \\
\text { Yes }\end{array}$ & 5 & 3 & 16 & 3 & 1 & 1 & $\begin{array}{c}29 \\
0\end{array}$ \\
\hline
\end{tabular}




\begin{tabular}{|c|c|c|c|c|c|c|c|c|}
\hline $\begin{array}{l}\text { Category 5-3 } \\
\text { present in PD? }\end{array}$ & $\begin{array}{r}\text { No } \\
\text { Yes }\end{array}$ & 5 & 3 & 16 & 3 & 1 & 1 & $\begin{array}{c}29 \\
0\end{array}$ \\
\hline $\begin{array}{l}\text { Category 5-4 } \\
\text { present in PD? }\end{array}$ & $\begin{array}{r}\text { No } \\
\text { Yes }\end{array}$ & 5 & 3 & $\begin{array}{c}15 \\
1\end{array}$ & 3 & 1 & 1 & $\begin{array}{c}28 \\
1\end{array}$ \\
\hline $\begin{array}{l}\text { Category 6-1 } \\
\text { present in PD? }\end{array}$ & $\begin{array}{l}\text { No } \\
\text { Yes }\end{array}$ & $\begin{array}{l}3 \\
2\end{array}$ & 3 & $\begin{array}{c}14 \\
2\end{array}$ & 3 & 1 & 1 & $\begin{array}{c}24 \\
5\end{array}$ \\
\hline $\begin{array}{l}\text { Category 6-2 } \\
\text { present in PD? }\end{array}$ & $\begin{array}{r}\text { No } \\
\text { Yes }\end{array}$ & $\begin{array}{l}4 \\
1\end{array}$ & 3 & $\begin{array}{c}14 \\
2\end{array}$ & 3 & 1 & 1 & $\begin{array}{c}26 \\
3\end{array}$ \\
\hline $\begin{array}{l}\text { Category 6-3 } \\
\text { present in PD? }\end{array}$ & $\begin{array}{l}\text { No } \\
\text { Yes }\end{array}$ & 5 & 3 & 16 & 3 & 1 & 1 & $\begin{array}{c}29 \\
0\end{array}$ \\
\hline $\begin{array}{l}\text { Category 6-4 } \\
\text { present in PD? }\end{array}$ & $\begin{array}{r}\text { No } \\
\text { Yes }\end{array}$ & 5 & 3 & 16 & 3 & 1 & 1 & $\begin{array}{c}29 \\
0\end{array}$ \\
\hline $\begin{array}{l}\text { Category 7-1 } \\
\text { present in PD? }\end{array}$ & $\begin{array}{l}\text { No } \\
\text { Yes }\end{array}$ & 5 & 3 & $\begin{array}{c}13 \\
3\end{array}$ & 3 & 1 & 1 & $\begin{array}{c}25 \\
4\end{array}$ \\
\hline $\begin{array}{l}\text { Category 7-2 } \\
\text { present in PD? }\end{array}$ & $\begin{array}{l}\text { No } \\
\text { Yes }\end{array}$ & $\begin{array}{l}3 \\
2\end{array}$ & 3 & $\begin{array}{c}13 \\
3\end{array}$ & 3 & 1 & 1 & $\begin{array}{c}23 \\
6\end{array}$ \\
\hline $\begin{array}{l}\text { Category 7-3 } \\
\text { present in PD? }\end{array}$ & $\begin{array}{r}\text { No } \\
\text { Yes }\end{array}$ & 5 & $\begin{array}{l}2 \\
1\end{array}$ & $\begin{array}{c}14 \\
2\end{array}$ & 3 & 1 & 1 & $\begin{array}{c}26 \\
3\end{array}$ \\
\hline $\begin{array}{l}\text { Category 7-4 } \\
\text { present in PD? }\end{array}$ & $\begin{array}{r}\text { No } \\
\text { Yes }\end{array}$ & $\begin{array}{l}3 \\
2\end{array}$ & 3 & $\begin{array}{c}13 \\
3\end{array}$ & $\begin{array}{l}2 \\
1\end{array}$ & 1 & 1 & $\begin{array}{c}21 \\
8\end{array}$ \\
\hline $\begin{array}{l}\text { Total in Occ. } \\
\text { Class }\end{array}$ & & 5 & 3 & 16 & 3 & 1 & 1 & 29 \\
\hline
\end{tabular}




\section{Frequencies}

Number of position descriptions coded $=29$

\begin{tabular}{lcc}
\hline Coding category & Present in PD & Not present in PD \\
\hline (1-1) Research planning - Develop question & & $29(100)^{\mathrm{a}}$ \\
(1-2) Research planning - Design study & $7(24)^{\mathrm{a}}$ & $22(76)$ \\
(1-3) Research planning - Write proposal & & $29(100)$ \\
(1-4) Research planning - Develop research program & $1(3)$ & $28(97)$ \\
(2-1) Research execution - Collect data & $9(31)$ & $20(69)$ \\
(2-2) Research execution - Database management & & $29(100)$ \\
(2-3) Research execution - Conduct surveys & $1(3)$ & $28(97)$ \\
(2-4) Research execution - Conduct studies/experiments & & $29(100)$ \\
(2-5) Research execution - Conduct inventories & $2(7)$ & $27(93)$ \\
(2-6) Research execution - Conduct monitoring & $2(7)$ & $27(93)$ \\
(2-7) Research execution - Conduct literature review & & $29(100)$ \\
(3-1) Research analyses - Analyze data & $10(35)$ & $19(66)$ \\
(4-1) Research dissemination - Write reports & $3(10)$ & $26(90)$ \\
(4-2) Research dissemination - Publication & $3(10)$ & $26(90)$ \\
(4-3) Research dissemination - Presentation & $1(3)$ & $28(97)$ \\
(5-1) Research application - Management actions & $14(48)$ & $15(52)$ \\
(5-2) Research application - Policy makers & & $29(100)$ \\
(5-3) Research application - Decision documents & & $29(100)$ \\
(5-4) Research application - New techniques & $1(3)$ & $28(97)$ \\
(6-1) Research collaboration - Non-FWS & $5(17)$ & $24(83)$ \\
(6-2) Research collaboration - Supervision & $3(10)$ & $26(90)$ \\
(6-3) Research collaboration - Identify funding & & $29(100)$ \\
(6-4) Research collaboration - Write funding proposal & $4(14)$ & $29(100)$ \\
(7-1) Knowledge/skill/ability required - Data analysis & $6(21)$ & $25(86)$ \\
(7-2) Knowledge/skill/ability required - Research methods & $3(10)$ & $23(79)$ \\
(7-3) Knowledge/skill/ability required - Statistical software & $8(28)$ & $26(90)$ \\
(7-4) Knowledge/skill/ability required - Document preparation & & $21(72)$ \\
\hline
\end{tabular}

${ }^{\mathrm{a}}$ Percentages in parentheses. 


\section{Region 5}

\section{Intercoder Agreement}

\begin{tabular}{|c|c|c|c|c|}
\hline \multirow[b]{2}{*}{ Variable } & \multicolumn{2}{|c|}{$\begin{array}{c}\text { Original data } \\
\% \text { agreement }=90 \%\end{array}$} & \multicolumn{2}{|c|}{$\begin{array}{c}\text { Consensus data } \\
\text { No consensus needed }\end{array}$} \\
\hline & Kappa & Significance & Kappa & Significance \\
\hline (1-1) Planning - Research question & & - & & \\
\hline (1-2) Planning - Design & $.62^{\mathrm{a}}$ & .00 & & \\
\hline (1-3) Planning - Write proposal & $.84^{\mathrm{a}}$ & .00 & & \\
\hline (1-4) Planning - Develop program & $.62^{\mathrm{a}}$ & .00 & & \\
\hline (2-1) Execution - Data collection & $.62^{\mathrm{a}}$ & .00 & & \\
\hline (2-2) Execution - Manage data & $.53^{\mathrm{a}}$ & .00 & & \\
\hline (2-3) Execution - Survey & $\mathrm{b}$ & - & & \\
\hline (2-4) Execution - Study & $.65^{\mathrm{a}}$ & .00 & & \\
\hline (2-5) Execution - Inventory & .33 & .06 & & \\
\hline (2-6) Execution - Monitoring & -.05 & .70 & & \\
\hline (2-7) Execution - Literature review & $.84^{\mathrm{a}}$ & .00 & & \\
\hline (3) Analyses & $.94^{\mathrm{a}}$ & .00 & & \\
\hline (4-1) Dissemination - Reports & $.66^{\mathrm{a}}$ & .00 & & \\
\hline (4-2) Dissemination - Publication & $\mathrm{b}$ & - & & \\
\hline (4-3) Dissemination - Presentation & $.65^{\mathrm{a}}$ & .00 & & \\
\hline (5-1) Application - Management & $.45^{\mathrm{a}}$ & .01 & & \\
\hline (5-2) Application - Policy makers & $1.00^{\mathrm{a}}$ & .00 & & \\
\hline (5-3) Application - Decision documents & & - & & \\
\hline (5-4) Application - New approaches & b & - & & \\
\hline (6-1) Collaboration - Non-FWS & $.37^{\mathrm{a}}$ & .04 & & \\
\hline (6-2) Collaboration - Supervision & $.61^{\mathrm{a}}$ & .00 & & \\
\hline (6-3) Collaboration - Funding & $1.00^{\mathrm{a}}$ & .00 & & \\
\hline (6-4) Collaboration - Grants & & - & & \\
\hline (7-1) KSA - Data analysis & $.87^{\mathrm{a}}$ & .00 & & \\
\hline (7-2) KSA - Methods & $.69^{\mathrm{a}}$ & .00 & & \\
\hline (7-3) KSA - Software & $.78^{\mathrm{a}}$ & .00 & & \\
\hline (7-4) KSA - Document & $.75^{\mathrm{a}}$ & .00 & & \\
\hline
\end{tabular}

${ }^{\mathrm{a}}$ Significant at $p<.05$

${ }^{\mathrm{b}}$ Kappa is not computed when at least one variable in the 2-way table is a constant. 


\section{Region 5}

\section{Latent Content Analysis Results}

Total number of position descriptions (PDs) coded for Region $5=32$

Number of PDs from published individuals $=12$

Number of PDs from non published individuals $=20$

Percentages are rounded and may not total 100.

\section{Publication Status}

Each coding category was analyzed using a Chi-square, Fisher's exact test when necessary due to sparseness, to determine if the category related to whether or not a person had published. Significant $($ at $p<.05)$ results were found for the following categories:

(3-1) Research analyses - Analyzing data using qualitative or quantitative methods

$\chi^{2}=4.80$

$p h i=.39$. This measure of the strength of the association indicates a moderately strong relationship.

\section{Category 3-1 present in PD?}

\begin{tabular}{r|ccc}
\multicolumn{1}{c}{} & \multicolumn{3}{c}{ Publication status } \\
\multicolumn{1}{c}{} & No & Yes & Total \\
\cline { 2 - 4 } No & 13 & 3 & 16 \\
Yes & 7 & 9 & 16 \\
Total & 20 & 12 & 32
\end{tabular}

Of the people who had published, $75 \%$ of them had category 3-1 content in their PDs.

Of the people who had category 3-1 content in their PDs, $56 \%$ of them had published.

(6-1) Research collaboration - Collaborate with non-FWS personnel on research projects

$\chi^{2}=4.10$

$p h i=.36$. This measure of the strength of the association indicates a moderate relationship.

Category 6-1 present in PD?

\begin{tabular}{r|ccc}
\multicolumn{2}{c}{} & \multicolumn{2}{c}{ Publication status } \\
\multicolumn{1}{c}{} & No & Yes & Total \\
\cline { 2 - 4 } No & 14 & 4 & 18 \\
Yes & 6 & 8 & 14 \\
Total & 20 & 12 & 32
\end{tabular}

Of the people who had published, 67\% of them had category 6-1 content in their PDs.

Of the people who had category 6-1 content in their PDs, $57 \%$ of them had published. 
(6-2) Research collaboration - Supervise or coordinate other FWS employees on research projects

$\chi^{2}=5.40$

$p h i=.41$. This measure of the strength of the association indicates a moderately strong relationship.

Category 6-2 present in PD?

\begin{tabular}{|c|c|c|c|}
\hline & & ion st & \\
\hline & No & Yes & Total \\
\hline No & 15 & 4 & 19 \\
\hline Yes & 5 & 8 & 13 \\
\hline Total & 20 & 12 & 32 \\
\hline
\end{tabular}

Of the people who had published, 67\% of them had category 6-2 content in their PDs.

Of the people who had category 6-2 content in their PDs, $62 \%$ of them had published.

(7-1) Knowledge/skill/ability required - Statistical data analysis

$\chi^{2}=4.10$

$p h i=.36$. This measure of the strength of the association indicates a moderate relationship.

\section{Category 7-1 present in PD?}

Of the people who had published, $67 \%$ of them had category 7-1 content in their PDs.
Publication status

\begin{tabular}{r|ccc}
\multicolumn{1}{c}{} & No & Yes & Total \\
\cline { 2 - 4 } No & 14 & 4 & 18 \\
Yes & 6 & 8 & 14 \\
Total & 20 & 12 & 32
\end{tabular}

Of the people who had category 7-1 content in their PDs, $57 \%$ of them had published. 
GS Level

Even when using only the GS levels with the highest numbers of PDs, there was still too much sparseness in the data to allow for analyses at the regional level. The frequencies are provided for all content categories.

\begin{tabular}{|c|c|c|c|c|c|c|c|}
\hline & & & & 13 & 14 & 15 & lotal \\
\hline $\begin{array}{l}\text { Category 1-1 } \\
\text { present in PD? }\end{array}$ & $\begin{array}{r}\text { No } \\
\text { Yes }\end{array}$ & $\begin{array}{c}10 \\
1\end{array}$ & 6 & 11 & 3 & 1 & $\begin{array}{c}31 \\
1\end{array}$ \\
\hline $\begin{array}{l}\text { Category 1-2 } \\
\text { present in PD? }\end{array}$ & $\begin{array}{r}\text { No } \\
\text { Yes }\end{array}$ & $\begin{array}{l}3 \\
8\end{array}$ & $\begin{array}{l}4 \\
2\end{array}$ & $\begin{array}{l}7 \\
4\end{array}$ & 3 & 1 & $\begin{array}{l}18 \\
14\end{array}$ \\
\hline $\begin{array}{l}\text { Category 1-3 } \\
\text { present in PD? }\end{array}$ & $\begin{array}{r}\text { No } \\
\text { Yes }\end{array}$ & $\begin{array}{l}9 \\
2\end{array}$ & $\begin{array}{l}5 \\
1\end{array}$ & 11 & 3 & 1 & $\begin{array}{c}29 \\
3\end{array}$ \\
\hline $\begin{array}{l}\text { Category 1-4 } \\
\text { present in PD? }\end{array}$ & $\begin{array}{r}\text { No } \\
\text { Yes }\end{array}$ & $\begin{array}{l}8 \\
3\end{array}$ & $\begin{array}{l}3 \\
3\end{array}$ & $\begin{array}{l}5 \\
6\end{array}$ & $\begin{array}{l}1 \\
2\end{array}$ & 1 & $\begin{array}{l}17 \\
15\end{array}$ \\
\hline $\begin{array}{l}\text { Category 2-1 } \\
\text { present in PD? }\end{array}$ & $\begin{array}{r}\text { No } \\
\text { Yes }\end{array}$ & $\begin{array}{l}4 \\
7\end{array}$ & $\begin{array}{l}2 \\
4\end{array}$ & $\begin{array}{l}7 \\
4\end{array}$ & 3 & 1 & $\begin{array}{l}17 \\
15\end{array}$ \\
\hline $\begin{array}{l}\text { Category 2-2 } \\
\text { present in PD? }\end{array}$ & $\begin{array}{r}\text { No } \\
\text { Yes }\end{array}$ & $\begin{array}{c}10 \\
1\end{array}$ & 6 & $\begin{array}{l}7 \\
4\end{array}$ & 3 & 1 & $\begin{array}{c}27 \\
5\end{array}$ \\
\hline $\begin{array}{l}\text { Category 2-3 } \\
\text { present in PD? }\end{array}$ & $\begin{array}{r}\text { No } \\
\text { Yes }\end{array}$ & 11 & 6 & 11 & 3 & 1 & $\begin{array}{c}32 \\
0\end{array}$ \\
\hline $\begin{array}{l}\text { Category 2-4 } \\
\text { present in PD? }\end{array}$ & $\begin{array}{r}\text { No } \\
\text { Yes }\end{array}$ & $\begin{array}{c}10 \\
1\end{array}$ & 6 & 11 & 3 & 1 & $\begin{array}{c}31 \\
1\end{array}$ \\
\hline $\begin{array}{l}\text { Category 2-5 } \\
\text { present in PD? }\end{array}$ & $\begin{array}{r}\text { No } \\
\text { Yes }\end{array}$ & $\begin{array}{l}6 \\
5\end{array}$ & $\begin{array}{l}3 \\
3\end{array}$ & $\begin{array}{l}9 \\
2\end{array}$ & 3 & 1 & $\begin{array}{l}22 \\
10\end{array}$ \\
\hline $\begin{array}{l}\text { Category 2-6 } \\
\text { present in PD? }\end{array}$ & $\begin{array}{r}\text { No } \\
\text { Yes }\end{array}$ & $\begin{array}{l}9 \\
2\end{array}$ & $\begin{array}{l}5 \\
1\end{array}$ & $\begin{array}{c}10 \\
1\end{array}$ & 3 & 1 & $\begin{array}{c}28 \\
4\end{array}$ \\
\hline $\begin{array}{l}\text { Category 2-7 } \\
\text { present in PD? }\end{array}$ & $\begin{array}{r}\text { No } \\
\text { Yes }\end{array}$ & $\begin{array}{l}9 \\
2\end{array}$ & $\begin{array}{l}5 \\
1\end{array}$ & 11 & 3 & 1 & $\begin{array}{c}29 \\
3\end{array}$ \\
\hline $\begin{array}{l}\text { Category 3-1 } \\
\text { present in PD? }\end{array}$ & $\begin{array}{r}\text { No } \\
\text { Yes }\end{array}$ & $\begin{array}{l}6 \\
5\end{array}$ & $\begin{array}{l}2 \\
4\end{array}$ & $\begin{array}{l}5 \\
6\end{array}$ & $\begin{array}{l}2 \\
1\end{array}$ & 1 & $\begin{array}{l}16 \\
16\end{array}$ \\
\hline $\begin{array}{l}\text { Category 4-1 } \\
\text { present in PD? }\end{array}$ & $\begin{array}{r}\text { No } \\
\text { Yes }\end{array}$ & $\begin{array}{l}6 \\
5\end{array}$ & $\begin{array}{l}2 \\
4\end{array}$ & $\begin{array}{l}9 \\
2\end{array}$ & 3 & 1 & $\begin{array}{l}21 \\
11\end{array}$ \\
\hline $\begin{array}{l}\text { Category 4-2 } \\
\text { present in PD? }\end{array}$ & $\begin{array}{r}\text { No } \\
\text { Yes }\end{array}$ & 11 & 6 & 11 & 3 & 1 & $\begin{array}{c}32 \\
0\end{array}$ \\
\hline $\begin{array}{l}\text { Category 4-3 } \\
\text { present in PD? }\end{array}$ & $\begin{array}{r}\text { No } \\
\text { Yes }\end{array}$ & $\begin{array}{c}10 \\
1\end{array}$ & 6 & 11 & 3 & 1 & $\begin{array}{c}31 \\
1\end{array}$ \\
\hline $\begin{array}{l}\text { Category 5-1 } \\
\text { present in PD? }\end{array}$ & $\begin{array}{r}\text { No } \\
\text { Yes }\end{array}$ & $\begin{array}{l}8 \\
3\end{array}$ & $\begin{array}{l}3 \\
3\end{array}$ & $\begin{array}{l}7 \\
4\end{array}$ & 3 & 1 & $\begin{array}{l}22 \\
10\end{array}$ \\
\hline $\begin{array}{l}\text { Category 5-2 } \\
\text { present in PD? }\end{array}$ & $\begin{array}{r}\text { No } \\
\text { Yes }\end{array}$ & 11 & 6 & $\begin{array}{c}10 \\
1\end{array}$ & 3 & 1 & $\begin{array}{c}31 \\
1\end{array}$ \\
\hline $\begin{array}{l}\text { Category 5-3 } \\
\text { present in PD? }\end{array}$ & $\begin{array}{l}\text { No } \\
\text { Yes }\end{array}$ & 11 & 6 & 11 & 3 & 1 & $\begin{array}{c}32 \\
0\end{array}$ \\
\hline
\end{tabular}




\begin{tabular}{|c|c|c|c|c|c|c|c|}
\hline & & 11 & 12 & $\begin{array}{c}\text { S level } \\
13 \\
\end{array}$ & 14 & 15 & Total \\
\hline $\begin{array}{l}\text { Category 5-4 } \\
\text { present in PD? }\end{array}$ & $\begin{array}{r}\text { No } \\
\text { Yes }\end{array}$ & 11 & 6 & 11 & 3 & 1 & $\begin{array}{c}32 \\
0\end{array}$ \\
\hline $\begin{array}{l}\text { Category 6-1 } \\
\text { present in PD? }\end{array}$ & $\begin{array}{r}\text { No } \\
\text { Yes }\end{array}$ & $\begin{array}{l}4 \\
7\end{array}$ & $\begin{array}{l}4 \\
2\end{array}$ & $\begin{array}{l}7 \\
4\end{array}$ & 3 & 1 & $\begin{array}{l}18 \\
14\end{array}$ \\
\hline $\begin{array}{l}\text { Category 6-2 } \\
\text { present in PD? }\end{array}$ & $\begin{array}{r}\text { No } \\
\text { Yes }\end{array}$ & $\begin{array}{l}9 \\
2\end{array}$ & $\begin{array}{l}2 \\
4\end{array}$ & $\begin{array}{l}7 \\
4\end{array}$ & $\begin{array}{l}1 \\
2\end{array}$ & 1 & $\begin{array}{l}19 \\
13\end{array}$ \\
\hline $\begin{array}{l}\text { Category 6-3 } \\
\text { present in PD? }\end{array}$ & $\begin{array}{r}\text { No } \\
\text { Yes }\end{array}$ & 11 & 6 & $\begin{array}{c}10 \\
1\end{array}$ & 3 & 1 & $\begin{array}{c}31 \\
1\end{array}$ \\
\hline $\begin{array}{l}\text { Category 6-4 } \\
\text { present in PD? }\end{array}$ & $\begin{array}{r}\text { No } \\
\text { Yes }\end{array}$ & 11 & 6 & 11 & 3 & 1 & $\begin{array}{c}32 \\
0\end{array}$ \\
\hline $\begin{array}{l}\text { Category 7-1 } \\
\text { present in PD? }\end{array}$ & $\begin{array}{r}\text { No } \\
\text { Yes }\end{array}$ & $\begin{array}{l}6 \\
5\end{array}$ & $\begin{array}{l}2 \\
4\end{array}$ & $\begin{array}{l}6 \\
5\end{array}$ & 3 & 1 & $\begin{array}{l}18 \\
14\end{array}$ \\
\hline $\begin{array}{l}\text { Category 7-2 } \\
\text { present in PD? }\end{array}$ & $\begin{array}{r}\text { No } \\
\text { Yes }\end{array}$ & $\begin{array}{l}4 \\
7\end{array}$ & $\begin{array}{l}1 \\
5\end{array}$ & $\begin{array}{l}8 \\
3\end{array}$ & 3 & 1 & $\begin{array}{l}17 \\
15\end{array}$ \\
\hline $\begin{array}{l}\text { Category 7-3 } \\
\text { present in PD? }\end{array}$ & $\begin{array}{r}\text { No } \\
\text { Yes }\end{array}$ & $\begin{array}{c}10 \\
1\end{array}$ & 6 & $\begin{array}{c}10 \\
1\end{array}$ & 3 & 1 & $\begin{array}{c}30 \\
2\end{array}$ \\
\hline $\begin{array}{l}\text { Category 7-4 } \\
\text { present in PD? }\end{array}$ & $\begin{array}{r}\text { No } \\
\text { Yes }\end{array}$ & $\begin{array}{l}5 \\
6\end{array}$ & $\begin{array}{l}3 \\
3\end{array}$ & $\begin{array}{l}7 \\
4\end{array}$ & 3 & 1 & $\begin{array}{l}19 \\
13\end{array}$ \\
\hline Total in GS Level & & 11 & 6 & 11 & 3 & 1 & 32 \\
\hline
\end{tabular}


Even when using only the occupational classifications with the highest numbers of PDs, there was still too much sparseness in the data to allow for analyses at the regional level. The frequencies are provided for all content categories.

\begin{tabular}{|c|c|c|c|c|c|c|c|}
\hline & & & & & & & \\
\hline $\begin{array}{l}\text { Category 1-1 } \\
\text { present in PD? }\end{array}$ & $\begin{array}{l}\text { No } \\
\text { Yes }\end{array}$ & $\begin{array}{c}13 \\
1\end{array}$ & 3 & 11 & 1 & 3 & $\begin{array}{c}31 \\
1\end{array}$ \\
\hline $\begin{array}{l}\text { Category 1-2 } \\
\text { present in PD? }\end{array}$ & $\begin{array}{r}\text { No } \\
\text { Yes }\end{array}$ & $\begin{array}{l}5 \\
9\end{array}$ & 3 & $\begin{array}{l}8 \\
3\end{array}$ & 1 & $\begin{array}{l}1 \\
2\end{array}$ & $\begin{array}{l}18 \\
14\end{array}$ \\
\hline $\begin{array}{l}\text { Category 1-3 } \\
\text { present in PD? }\end{array}$ & $\begin{array}{r}\text { No } \\
\text { Yes }\end{array}$ & $\begin{array}{c}11 \\
3\end{array}$ & 3 & 11 & 1 & 3 & $\begin{array}{c}29 \\
3\end{array}$ \\
\hline $\begin{array}{l}\text { Category 1-4 } \\
\text { present in PD? }\end{array}$ & $\begin{array}{l}\text { No } \\
\text { Yes }\end{array}$ & $\begin{array}{l}7 \\
7\end{array}$ & $\begin{array}{l}1 \\
2\end{array}$ & $\begin{array}{l}8 \\
3\end{array}$ & 1 & $\begin{array}{l}1 \\
2\end{array}$ & $\begin{array}{l}17 \\
15\end{array}$ \\
\hline $\begin{array}{l}\text { Category 2-1 } \\
\text { present in PD? }\end{array}$ & $\begin{array}{r}\text { No } \\
\text { Yes }\end{array}$ & $\begin{array}{l}5 \\
9\end{array}$ & 3 & $\begin{array}{l}6 \\
5\end{array}$ & 1 & 3 & $\begin{array}{l}17 \\
15\end{array}$ \\
\hline $\begin{array}{l}\text { Category 2-2 } \\
\text { present in PD? }\end{array}$ & $\begin{array}{l}\text { No } \\
\text { Yes }\end{array}$ & $\begin{array}{c}13 \\
1\end{array}$ & 3 & $\begin{array}{l}7 \\
4\end{array}$ & 1 & 3 & $\begin{array}{c}27 \\
5\end{array}$ \\
\hline $\begin{array}{l}\text { Category 2-3 } \\
\text { present in PD? }\end{array}$ & $\begin{array}{r}\text { No } \\
\text { Yes }\end{array}$ & 14 & 3 & 11 & 1 & 3 & $\begin{array}{c}32 \\
0\end{array}$ \\
\hline $\begin{array}{l}\text { Category 2-4 } \\
\text { present in PD? }\end{array}$ & $\begin{array}{l}\text { No } \\
\text { Yes }\end{array}$ & $\begin{array}{c}13 \\
1\end{array}$ & 3 & 11 & 1 & 3 & $\begin{array}{c}31 \\
1\end{array}$ \\
\hline $\begin{array}{l}\text { Category 2-5 } \\
\text { present in PD? }\end{array}$ & $\begin{array}{l}\text { No } \\
\text { Yes }\end{array}$ & $\begin{array}{l}8 \\
6\end{array}$ & 3 & $\begin{array}{l}8 \\
3\end{array}$ & 1 & $\begin{array}{l}2 \\
1\end{array}$ & $\begin{array}{l}22 \\
10\end{array}$ \\
\hline $\begin{array}{l}\text { Category 2-6 } \\
\text { present in PD? }\end{array}$ & $\begin{array}{l}\text { No } \\
\text { Yes }\end{array}$ & $\begin{array}{c}11 \\
3\end{array}$ & 3 & 11 & 1 & 3 & $\begin{array}{c}28 \\
4\end{array}$ \\
\hline $\begin{array}{l}\text { Category 2-7 } \\
\text { present in PD? }\end{array}$ & $\begin{array}{l}\text { No } \\
\text { Yes }\end{array}$ & $\begin{array}{c}11 \\
3\end{array}$ & 3 & 11 & 1 & 3 & $\begin{array}{c}29 \\
3\end{array}$ \\
\hline $\begin{array}{l}\text { Category 3-1 } \\
\text { present in PD? }\end{array}$ & $\begin{array}{r}\text { No } \\
\text { Yes }\end{array}$ & $\begin{array}{l}6 \\
8\end{array}$ & $\begin{array}{l}2 \\
1\end{array}$ & $\begin{array}{l}6 \\
5\end{array}$ & 1 & $\begin{array}{l}1 \\
2\end{array}$ & $\begin{array}{l}16 \\
16\end{array}$ \\
\hline $\begin{array}{l}\text { Category 4-1 } \\
\text { present in PD? }\end{array}$ & $\begin{array}{l}\text { No } \\
\text { Yes }\end{array}$ & $\begin{array}{l}6 \\
8\end{array}$ & 3 & $\begin{array}{l}8 \\
3\end{array}$ & 1 & 3 & $\begin{array}{l}21 \\
11\end{array}$ \\
\hline $\begin{array}{l}\text { Category 4-2 } \\
\text { present in PD? }\end{array}$ & $\begin{array}{l}\text { No } \\
\text { Yes }\end{array}$ & 14 & 3 & 11 & 1 & 3 & $\begin{array}{c}32 \\
0\end{array}$ \\
\hline $\begin{array}{l}\text { Category 4-3 } \\
\text { present in PD? }\end{array}$ & $\begin{array}{l}\text { No } \\
\text { Yes }\end{array}$ & $\begin{array}{c}13 \\
1\end{array}$ & 3 & 11 & 1 & 3 & $\begin{array}{c}31 \\
1\end{array}$ \\
\hline $\begin{array}{l}\text { Category 5-1 } \\
\text { present in PD? }\end{array}$ & $\begin{array}{l}\text { No } \\
\text { Yes }\end{array}$ & $\begin{array}{l}8 \\
6\end{array}$ & 3 & $\begin{array}{c}10 \\
1\end{array}$ & 1 & $\begin{array}{l}1 \\
2\end{array}$ & $\begin{array}{l}22 \\
10\end{array}$ \\
\hline $\begin{array}{l}\text { Category 5-2 } \\
\text { present in PD? }\end{array}$ & $\begin{array}{l}\text { No } \\
\text { Yes }\end{array}$ & 14 & 3 & 11 & 1 & $\begin{array}{l}2 \\
1\end{array}$ & $\begin{array}{c}31 \\
1\end{array}$ \\
\hline
\end{tabular}


Category 5-3

present in PD?

Category 5-4

present in PD?

Category 6-1

present in PD?

Category 6-2

present in PD?

Category 6-3

present in PD?

Category 6-4

present in PD?

Category 7-1

present in PD?

Category 7-2

present in PD?

Category 7-3

present in PD?

Category 7-4

present in PD?

Total in Occ. Class

\begin{tabular}{|c|c|c|c|c|c|c|}
\hline & & & cupati & ificat & & \\
\hline & 401 & 480 & 482 & 485 & 486 & Total \\
\hline $\begin{array}{r}\text { No } \\
\text { Yes }\end{array}$ & 14 & 3 & 11 & 1 & 3 & $\begin{array}{c}32 \\
0\end{array}$ \\
\hline $\begin{array}{r}\text { No } \\
\text { Yes }\end{array}$ & 14 & 3 & 11 & 1 & 3 & $\begin{array}{c}32 \\
0\end{array}$ \\
\hline No & 8 & 2 & 6 & 1 & 1 & 18 \\
\hline Yes & 6 & 1 & 5 & & 2 & 14 \\
\hline No & 9 & 1 & 7 & 1 & 1 & 19 \\
\hline Yes & 5 & 2 & 4 & & 2 & 13 \\
\hline $\begin{array}{r}\text { No } \\
\text { Yes }\end{array}$ & 14 & 3 & $\begin{array}{c}10 \\
1\end{array}$ & 1 & 3 & $\begin{array}{c}31 \\
1\end{array}$ \\
\hline $\begin{array}{r}\text { No } \\
\text { Yes }\end{array}$ & 14 & 3 & 11 & 1 & 3 & $\begin{array}{c}32 \\
0\end{array}$ \\
\hline No & 6 & 3 & 8 & 1 & & 18 \\
\hline Yes & 8 & & 3 & & 3 & 14 \\
\hline No & 5 & 3 & 8 & 1 & & 17 \\
\hline Yes & 9 & & 3 & & 3 & 15 \\
\hline No & 14 & 3 & 10 & 1 & 2 & 30 \\
\hline Yes & & & 1 & & 1 & 2 \\
\hline No & 5 & 3 & 9 & & 2 & 19 \\
\hline Yes & 9 & & 2 & 1 & 1 & 13 \\
\hline & 14 & 3 & 11 & 1 & 3 & 32 \\
\hline
\end{tabular}




\section{Frequencies}

Number of position descriptions coded $=32$

\begin{tabular}{lcc}
\hline Coding category & Present in PD & Not present in PD \\
\hline (1-1) Research planning - Develop question & $1(3)^{\mathrm{a}}$ & $31(97)^{\mathrm{a}}$ \\
(1-2) Research planning - Design study & $14(44)$ & $18(56)$ \\
(1-3) Research planning - Write proposal & $3(9)$ & $29(91)$ \\
(1-4) Research planning - Develop research program & $15(47)$ & $17(53)$ \\
(2-1) Research execution - Collect data & $15(47)$ & $17(53)$ \\
(2-2) Research execution - Database management & $5(16)$ & $27(84)$ \\
(2-3) Research execution - Conduct surveys & & $32(100)$ \\
(2-4) Research execution - Conduct studies/experiments & $1(3)$ & $31(97)$ \\
(2-5) Research execution - Conduct inventories & $10(31)$ & $22(69)$ \\
(2-6) Research execution - Conduct monitoring & $4(13)$ & $28(88)$ \\
(2-7) Research execution - Conduct literature review & $3(9)$ & $29(91)$ \\
(3-1) Research analyses - Analyze data & $16(50)$ & $16(50)$ \\
(4-1) Research dissemination - Write reports & $11(34)$ & $21(66)$ \\
(4-2) Research dissemination - Publication & & $32(100)$ \\
(4-3) Research dissemination - Presentation & $1(3)$ & $31(97)$ \\
(5-1) Research application - Management actions & $10(31)$ & $22(69)$ \\
(5-2) Research application - Policy makers & $1(3)$ & $31(97)$ \\
(5-3) Research application - Decision documents & & $32(100)$ \\
(5-4) Research application - New techniques & & $32(100)$ \\
(6-1) Research collaboration - Non-FWS & $14(44)$ & $18(56)$ \\
(6-2) Research collaboration - Supervision & $13(41)$ & $19(59)$ \\
(6-3) Research collaboration - Identify funding & $1(3)$ & $31(97)$ \\
(6-4) Research collaboration - Write funding proposal & & $32(100)$ \\
(7-1) Knowledge/skill/ability required - Data analysis & $14(44)$ & $18(56)$ \\
(7-2) Knowledge/skill/ability required - Research methods & $15(47)$ & $17(53)$ \\
(7-3) Knowledge/skill/ability required - Statistical software & $2(6)$ & $30(94)$ \\
(7-4) Knowledge/skill/ability required - Document preparation & $19(41)$ & $19(59)$ \\
\hline
\end{tabular}

${ }^{\mathrm{a}}$ Percentages in parentheses. 


\section{Region 6}

\section{Intercoder Agreement}

\begin{tabular}{lcccc}
\hline & \multicolumn{2}{c}{ Original data } & \multicolumn{2}{c}{ Consensus data } \\
& $\%$ agreement $=92 \%$ & $\%$ agreement $=92 \%$ \\
Variable & Kappa & Significance & Kappa & Significance \\
\hline (1-1) Planning - Research question & $.66^{\mathrm{a}}$ & .00 & $1.0^{\mathrm{a}}$ & .00 \\
(1-2) Planning - Design & $.66^{\mathrm{a}}$ & .00 & $.66^{\mathrm{a}}$ & .00 \\
(1-3) Planning - Write proposal & $.72^{\mathrm{a}}$ & .00 & $.80^{\mathrm{a}}$ & .00 \\
(1-4) Planning - Develop program & $.83^{\mathrm{a}}$ & .00 & $.91^{\mathrm{a}}$ & .00 \\
(2-1) Execution - Data collection & $.84^{\mathrm{a}}$ & .00 & $.84^{\mathrm{a}}$ & .00 \\
(2-2) Execution - Manage data & $.87^{\mathrm{a}}$ & .00 & $.87^{\mathrm{a}}$ & .00 \\
(2-3) Execution - Survey & $\mathrm{b}$ & - & $\mathrm{b}$ & - \\
(2-4) Execution - Study & $\mathrm{b}$ & - & $\mathrm{b}$ & - \\
(2-5) Execution - Inventory & $.94^{\mathrm{a}}$ & .00 & $.94^{\mathrm{a}}$ & .00 \\
(2-6) Execution - Monitoring & $.75^{\mathrm{a}}$ & .00 & $.80^{\mathrm{a}}$ & .00 \\
(2-7) Execution - Literature review & $.48^{\mathrm{a}}$ & .00 & $.48^{\mathrm{a}}$ & .00 \\
(3) Analyses & $.76^{\mathrm{a}}$ & .00 & $.76^{\mathrm{a}}$ & .00 \\
(4-1) Dissemination - Reports & $.59^{\mathrm{a}}$ & .00 & $.67^{\mathrm{a}}$ & .00 \\
(4-2) Dissemination - Publication & $.87^{\mathrm{a}}$ & .00 & $.87^{\mathrm{a}}$ & .00 \\
(4-3) Dissemination - Presentation & $1.0^{\mathrm{a}}$ & .00 & $1.0^{\mathrm{a}}$ & .00 \\
(5-1) Application - Management & .28 & .08 & $.35^{\mathrm{a}}$ & .03 \\
(5-2) Application - Policy makers & $\mathrm{b}$ & - & $\mathrm{b}^{\mathrm{a}}$ & - \\
(5-3) Application - Decision documents & $\mathrm{b}$ & - & $\mathrm{b}^{\mathrm{b}}$ & - \\
(5-4) Application - New approaches & $\mathrm{b}$ & - & $\mathrm{b}$ & - \\
(6-1) Collaboration - Non-FWS & .27 & .07 & .27 & .07 \\
(6-2) Collaboration - Supervision & $.55^{\mathrm{a}}$ & .00 & $.55^{\mathrm{a}}$ & .00 \\
(6-3) Collaboration - Funding & $.66^{\mathrm{a}}$ & .00 & $.66^{\mathrm{a}}$ & .00 \\
(6-4) Collaboration - Grants & $1.0^{\mathrm{a}}$ & .00 & $1.0^{\mathrm{a}}$ & .00 \\
(7-1) KSA - Data analysis & $.84^{\mathrm{a}}$ & .00 & $.89^{\mathrm{a}}$ & .00 \\
(7-2) KSA - Methods & $.74^{\mathrm{a}}$ & .00 & $.79^{\mathrm{a}}$ & .00 \\
(7-3) KSA - Software & $1.0^{\mathrm{a}}$ & .00 & $1.0^{\mathrm{a}}$ & .00 \\
(7-4) KSA - Document & $.59^{\mathrm{a}}$ & .00 & $.66^{\mathrm{a}}$ & .00 \\
\hline
\end{tabular}

${ }^{\mathrm{a}}$ Significant at $p<.05$

${ }^{\mathrm{b}} \mathrm{Kappa}$ is not computed when at least one variable in the 2-way table is a constant. 


\section{Region 6}

\section{Latent Content Analysis Results}

Total number of position descriptions (PDs) coded for Region $6=38$

Number of PDs from published individuals $=20$

Number of PDs from non published individuals $=18$

Percentages are rounded and may not total 100.

Publication Status

Each coding category was analyzed using a Chi-square, Fisher's exact test when necessary due to sparseness, to determine if the category related to whether or not a person had published. No significant (at $p<.05)$ results were found for any categories.

GS Level

Even when using only the GS levels with the highest numbers of PDs, there was still too much sparseness in the data to allow for analyses at the regional level. The frequencies are provided for all content categories.

\begin{tabular}{|c|c|c|}
\hline $\begin{array}{l}\text { Category 1-1 } \\
\text { present in PD? }\end{array}$ & $\begin{array}{l}\text { No } \\
\text { Yes }\end{array}$ & 3 \\
\hline $\begin{array}{l}\text { Category 1-2 } \\
\text { present in PD? }\end{array}$ & $\begin{array}{r}\text { No } \\
\text { Yes }\end{array}$ & $\begin{array}{l}1 \\
2\end{array}$ \\
\hline $\begin{array}{l}\text { Category 1-3 } \\
\text { present in PD? }\end{array}$ & $\begin{array}{l}\text { No } \\
\text { Yes }\end{array}$ & 3 \\
\hline $\begin{array}{l}\text { Category 1-4 } \\
\text { present in PD? }\end{array}$ & $\begin{array}{r}\text { No } \\
\text { Yes }\end{array}$ & 3 \\
\hline $\begin{array}{l}\text { Category 2-1 } \\
\text { present in PD? }\end{array}$ & $\begin{array}{r}\text { No } \\
\text { Yes }\end{array}$ & $\begin{array}{l}1 \\
2\end{array}$ \\
\hline $\begin{array}{l}\text { Category 2-2 } \\
\text { present in PD? }\end{array}$ & $\begin{array}{l}\text { No } \\
\text { Yes }\end{array}$ & $\begin{array}{l}2 \\
1\end{array}$ \\
\hline $\begin{array}{l}\text { Category 2-3 } \\
\text { present in PD? }\end{array}$ & $\begin{array}{r}\text { No } \\
\text { Yes }\end{array}$ & 3 \\
\hline $\begin{array}{l}\text { Category 2-4 } \\
\text { present in PD? }\end{array}$ & $\begin{array}{r}\text { No } \\
\text { Yes }\end{array}$ & 3 \\
\hline $\begin{array}{l}\text { Category 2-5 } \\
\text { present in PD? }\end{array}$ & $\begin{array}{r}\text { No } \\
\text { Yes }\end{array}$ & $\begin{array}{l}1 \\
2\end{array}$ \\
\hline $\begin{array}{l}\text { Category 2-6 } \\
\text { present in PD? }\end{array}$ & $\begin{array}{r}\text { No } \\
\text { Yes }\end{array}$ & 3 \\
\hline $\begin{array}{l}\text { Category 2-7 } \\
\text { present in PD? }\end{array}$ & $\begin{array}{r}\text { No } \\
\text { Yes }\end{array}$ & 3 \\
\hline
\end{tabular}

GS level

\begin{tabular}{|c|c|c|c|c|}
\hline & 12 & 13 & 14 & Total \\
\hline & 11 & 8 & 4 & 36 \\
\hline & 2 & & & 2 \\
\hline & 5 & 6 & 4 & 24 \\
\hline & 8 & 2 & & 14 \\
\hline & 9 & 7 & 4 & 31 \\
\hline & 4 & 1 & & 7 \\
\hline & 11 & 7 & 3 & 31 \\
\hline & 2 & 1 & 1 & 7 \\
\hline & 7 & 7 & 4 & 23 \\
\hline & 6 & 1 & & 15 \\
\hline & 12 & 7 & 4 & 33 \\
\hline & 1 & 1 & & 5 \\
\hline & 13 & 8 & 4 & 38 \\
\hline & & & & 0 \\
\hline & 13 & 8 & 4 & 38 \\
\hline & & & & 0 \\
\hline 5 & 6 & 8 & 4 & 25 \\
\hline & 7 & & & 13 \\
\hline & 8 & 7 & 4 & 28 \\
\hline & 5 & 1 & & 10 \\
\hline & 13 & 8 & 4 & 37 \\
\hline & & & & 1 \\
\hline
\end{tabular}




\begin{tabular}{|c|c|c|c|c|c|c|c|}
\hline & & & & & & & \\
\hline & & 9 & 11 & 12 & 13 & 14 & Total \\
\hline Category 3-1 & No & 1 & 8 & 5 & 7 & 4 & 25 \\
\hline present in PD? & Yes & 2 & 2 & 8 & 1 & & 13 \\
\hline Category 4-1 & No & 2 & 8 & 7 & 7 & 4 & 28 \\
\hline present in PD? & Yes & 1 & 2 & 6 & 1 & & 10 \\
\hline Category 4-2 & No & 3 & 9 & 9 & 8 & 4 & 33 \\
\hline present in PD? & Yes & & 1 & 4 & & & 5 \\
\hline Category 4-3 & No & 3 & 9 & 10 & 7 & 4 & 33 \\
\hline present in PD? & Yes & & 1 & 3 & 1 & & 5 \\
\hline Category 5-1 & No & & 8 & 8 & 6 & 2 & 24 \\
\hline present in PD? & Yes & 3 & 2 & 5 & 2 & 2 & 14 \\
\hline Category 5-2 & No & 3 & 9 & 13 & 8 & 4 & 37 \\
\hline present in PD? & Yes & & 1 & & & & 1 \\
\hline Category 5-3 & No & 3 & 8 & 13 & 8 & 4 & 36 \\
\hline present in PD? & Yes & & 2 & & & & 2 \\
\hline Category 5-4 & No & 3 & 10 & 11 & 7 & 4 & 35 \\
\hline present in PD? & Yes & & & 2 & 1 & & 3 \\
\hline Category 6-1 & No & 3 & 9 & 9 & 7 & 4 & 32 \\
\hline present in PD? & Yes & & 1 & 4 & 1 & & 6 \\
\hline Category 6-2 & No & 2 & 8 & 10 & 8 & 3 & 31 \\
\hline present in PD? & Yes & 1 & 2 & 3 & & 1 & 7 \\
\hline Category 6-3 & No & 3 & 10 & 12 & 7 & 4 & 36 \\
\hline present in PD? & Yes & & & 1 & 1 & & 2 \\
\hline Category 6-4 & No & 3 & 9 & 13 & 8 & 4 & 37 \\
\hline present in PD? & Yes & & 1 & & & & 1 \\
\hline Category 7-1 & No & & 5 & 6 & 5 & 4 & 20 \\
\hline present in PD? & Yes & 3 & 5 & 7 & 3 & & 18 \\
\hline Category 7-2 & No & 1 & 6 & 3 & 4 & 3 & 17 \\
\hline present in PD? & Yes & 2 & 4 & 10 & 4 & 1 & 21 \\
\hline Category 7-3 & No & 3 & 10 & 11 & 8 & 4 & 36 \\
\hline present in PD? & Yes & & & 2 & & & 2 \\
\hline Category 7-4 & No & 2 & 7 & 9 & 8 & 2 & 28 \\
\hline present in PD? & Yes & 1 & 3 & 4 & & 2 & 10 \\
\hline Total in GS Level & & 3 & 10 & 13 & 8 & 4 & 38 \\
\hline
\end{tabular}


Even when using only the occupational classifications with the highest numbers of PDs, there was still too much sparseness in the data to allow for analyses at the regional level. The frequencies are provided for all content categories.

\begin{tabular}{|c|c|c|c|c|c|c|c|}
\hline \multirow[b]{2}{*}{$\begin{array}{l}\text { Category 1-1 } \\
\text { present in PD? }\end{array}$} & & & & & & & \\
\hline & $\begin{array}{r}\text { No } \\
\text { Yes }\end{array}$ & 10 & 1 & 3 & $\begin{array}{l}8 \\
2\end{array}$ & 14 & $\begin{array}{c}36 \\
2\end{array}$ \\
\hline $\begin{array}{l}\text { Category 1-2 } \\
\text { present in PD? }\end{array}$ & $\begin{array}{r}\text { No } \\
\text { Yes }\end{array}$ & $\begin{array}{l}9 \\
1\end{array}$ & 1 & 3 & $\begin{array}{l}5 \\
5\end{array}$ & $\begin{array}{l}6 \\
8\end{array}$ & $\begin{array}{l}24 \\
14\end{array}$ \\
\hline $\begin{array}{l}\text { Category 1-3 } \\
\text { present in PD? }\end{array}$ & $\begin{array}{r}\text { No } \\
\text { Yes }\end{array}$ & $\begin{array}{l}9 \\
1\end{array}$ & 1 & 3 & $\begin{array}{l}7 \\
3\end{array}$ & $\begin{array}{c}11 \\
3\end{array}$ & $\begin{array}{c}31 \\
7\end{array}$ \\
\hline $\begin{array}{l}\text { Category 1-4 } \\
\text { present in PD? }\end{array}$ & $\begin{array}{r}\text { No } \\
\text { Yes }\end{array}$ & $\begin{array}{l}8 \\
2\end{array}$ & 1 & 3 & 10 & $\begin{array}{l}9 \\
5\end{array}$ & $\begin{array}{c}31 \\
7\end{array}$ \\
\hline $\begin{array}{l}\text { Category 2-1 } \\
\text { present in PD? }\end{array}$ & $\begin{array}{r}\text { No } \\
\text { Yes }\end{array}$ & $\begin{array}{l}5 \\
5\end{array}$ & 1 & 3 & $\begin{array}{l}5 \\
5\end{array}$ & $\begin{array}{c}10 \\
4\end{array}$ & $\begin{array}{l}23 \\
15\end{array}$ \\
\hline $\begin{array}{l}\text { Category 2-2 } \\
\text { present in PD? }\end{array}$ & $\begin{array}{r}\text { No } \\
\text { Yes }\end{array}$ & $\begin{array}{l}9 \\
1\end{array}$ & 1 & 3 & $\begin{array}{l}9 \\
1\end{array}$ & $\begin{array}{c}11 \\
3\end{array}$ & $\begin{array}{c}33 \\
5\end{array}$ \\
\hline $\begin{array}{l}\text { Category 2-3 } \\
\text { present in PD? }\end{array}$ & $\begin{array}{r}\text { No } \\
\text { Yes }\end{array}$ & 10 & 1 & 3 & 10 & 14 & $\begin{array}{c}38 \\
0\end{array}$ \\
\hline $\begin{array}{l}\text { Category 2-4 } \\
\text { present in PD? }\end{array}$ & $\begin{array}{r}\text { No } \\
\text { Yes }\end{array}$ & 10 & 1 & 3 & 10 & 14 & $\begin{array}{c}38 \\
0\end{array}$ \\
\hline $\begin{array}{l}\text { Category 2-5 } \\
\text { present in PD? }\end{array}$ & $\begin{array}{r}\text { No } \\
\text { Yes }\end{array}$ & $\begin{array}{l}5 \\
5\end{array}$ & 1 & 3 & $\begin{array}{l}8 \\
2\end{array}$ & $\begin{array}{l}8 \\
6\end{array}$ & $\begin{array}{l}25 \\
13\end{array}$ \\
\hline $\begin{array}{l}\text { Category 2-6 } \\
\text { present in PD? }\end{array}$ & $\begin{array}{r}\text { No } \\
\text { Yes }\end{array}$ & 10 & 1 & 3 & $\begin{array}{l}6 \\
4\end{array}$ & $\begin{array}{l}9 \\
5\end{array}$ & $\begin{array}{l}28 \\
10\end{array}$ \\
\hline $\begin{array}{l}\text { Category 2-7 } \\
\text { present in PD? }\end{array}$ & $\begin{array}{r}\text { No } \\
\text { Yes }\end{array}$ & $\begin{array}{l}9 \\
1\end{array}$ & 1 & 3 & 10 & 14 & $\begin{array}{c}37 \\
1\end{array}$ \\
\hline $\begin{array}{l}\text { Category 3-1 } \\
\text { present in PD? }\end{array}$ & $\begin{array}{r}\text { No } \\
\text { Yes }\end{array}$ & $\begin{array}{l}7 \\
3\end{array}$ & 1 & 3 & $\begin{array}{l}7 \\
3\end{array}$ & $\begin{array}{l}7 \\
7\end{array}$ & $\begin{array}{l}25 \\
13\end{array}$ \\
\hline $\begin{array}{l}\text { Category 4-1 } \\
\text { present in PD? }\end{array}$ & $\begin{array}{r}\text { No } \\
\text { Yes }\end{array}$ & $\begin{array}{l}7 \\
3\end{array}$ & 1 & 3 & $\begin{array}{l}8 \\
2\end{array}$ & $\begin{array}{l}9 \\
5\end{array}$ & $\begin{array}{l}28 \\
10\end{array}$ \\
\hline $\begin{array}{l}\text { Category 4-2 } \\
\text { present in PD? }\end{array}$ & $\begin{array}{r}\text { No } \\
\text { Yes }\end{array}$ & 10 & 1 & 3 & $\begin{array}{l}7 \\
3\end{array}$ & $\begin{array}{c}12 \\
2\end{array}$ & $\begin{array}{c}33 \\
5\end{array}$ \\
\hline $\begin{array}{l}\text { Category 4-3 } \\
\text { present in PD? }\end{array}$ & $\begin{array}{r}\text { No } \\
\text { Yes }\end{array}$ & 10 & 1 & 3 & $\begin{array}{l}7 \\
3\end{array}$ & $\begin{array}{c}12 \\
2\end{array}$ & $\begin{array}{c}33 \\
5\end{array}$ \\
\hline $\begin{array}{l}\text { Category 5-1 } \\
\text { present in PD? }\end{array}$ & $\begin{array}{r}\text { No } \\
\text { Yes }\end{array}$ & $\begin{array}{l}7 \\
3\end{array}$ & 1 & $\begin{array}{l}2 \\
1\end{array}$ & $\begin{array}{l}6 \\
4\end{array}$ & $\begin{array}{l}9 \\
5\end{array}$ & $\begin{array}{l}24 \\
14\end{array}$ \\
\hline $\begin{array}{l}\text { Category 5-2 } \\
\text { present in PD? }\end{array}$ & $\begin{array}{r}\text { No } \\
\text { Yes }\end{array}$ & $\begin{array}{l}9 \\
1\end{array}$ & 1 & 3 & 10 & 14 & $\begin{array}{c}37 \\
1\end{array}$ \\
\hline
\end{tabular}




\begin{tabular}{|c|c|c|c|c|c|c|c|}
\hline $\begin{array}{l}\text { Category 5-3 } \\
\text { present in PD? }\end{array}$ & $\begin{array}{r}\text { No } \\
\text { Yes }\end{array}$ & $\begin{array}{l}9 \\
1\end{array}$ & 1 & 3 & 10 & $\begin{array}{c}13 \\
1\end{array}$ & $\begin{array}{c}36 \\
2\end{array}$ \\
\hline $\begin{array}{l}\text { Category 5-4 } \\
\text { present in PD? }\end{array}$ & $\begin{array}{l}\text { No } \\
\text { Yes }\end{array}$ & 10 & 1 & 3 & $\begin{array}{l}9 \\
1\end{array}$ & $\begin{array}{c}12 \\
2\end{array}$ & $\begin{array}{c}35 \\
3\end{array}$ \\
\hline $\begin{array}{l}\text { Category 6-1 } \\
\text { present in PD? }\end{array}$ & $\begin{array}{l}\text { No } \\
\text { Yes }\end{array}$ & $\begin{array}{l}9 \\
1\end{array}$ & 1 & 3 & $\begin{array}{l}8 \\
2\end{array}$ & $\begin{array}{c}11 \\
3\end{array}$ & $\begin{array}{c}32 \\
6\end{array}$ \\
\hline $\begin{array}{l}\text { Category 6-2 } \\
\text { present in PD? }\end{array}$ & $\begin{array}{l}\text { No } \\
\text { Yes }\end{array}$ & $\begin{array}{l}9 \\
1\end{array}$ & 1 & 3 & $\begin{array}{l}7 \\
3\end{array}$ & $\begin{array}{c}12 \\
2\end{array}$ & $\begin{array}{c}31 \\
7\end{array}$ \\
\hline $\begin{array}{l}\text { Category 6-3 } \\
\text { present in PD? }\end{array}$ & $\begin{array}{r}\text { No } \\
\text { Yes }\end{array}$ & 10 & 1 & 3 & 10 & $\begin{array}{c}12 \\
2\end{array}$ & $\begin{array}{c}36 \\
2\end{array}$ \\
\hline $\begin{array}{l}\text { Category 6-4 } \\
\text { present in PD? }\end{array}$ & $\begin{array}{l}\text { No } \\
\text { Yes }\end{array}$ & 10 & 1 & 3 & 10 & $\begin{array}{c}13 \\
1\end{array}$ & $\begin{array}{c}37 \\
1\end{array}$ \\
\hline $\begin{array}{l}\text { Category 7-1 } \\
\text { present in PD? }\end{array}$ & $\begin{array}{l}\text { No } \\
\text { Yes }\end{array}$ & $\begin{array}{l}6 \\
4\end{array}$ & 1 & 3 & $\begin{array}{l}6 \\
4\end{array}$ & $\begin{array}{l}5 \\
9\end{array}$ & $\begin{array}{l}20 \\
18\end{array}$ \\
\hline $\begin{array}{l}\text { Category 7-2 } \\
\text { present in PD? }\end{array}$ & $\begin{array}{l}\text { No } \\
\text { Yes }\end{array}$ & $\begin{array}{l}5 \\
5\end{array}$ & 1 & 3 & $\begin{array}{l}5 \\
5\end{array}$ & $\begin{array}{c}4 \\
10\end{array}$ & $\begin{array}{l}17 \\
21\end{array}$ \\
\hline $\begin{array}{l}\text { Category 7-3 } \\
\text { present in PD? }\end{array}$ & $\begin{array}{l}\text { No } \\
\text { Yes }\end{array}$ & 10 & 1 & 3 & $\begin{array}{l}8 \\
2\end{array}$ & 14 & $\begin{array}{c}36 \\
2\end{array}$ \\
\hline $\begin{array}{l}\text { Category 7-4 } \\
\text { present in PD? }\end{array}$ & $\begin{array}{r}\text { No } \\
\text { Yes }\end{array}$ & $\begin{array}{l}7 \\
3\end{array}$ & 1 & $\begin{array}{l}2 \\
1\end{array}$ & $\begin{array}{l}8 \\
2\end{array}$ & $\begin{array}{c}10 \\
4\end{array}$ & $\begin{array}{l}28 \\
10\end{array}$ \\
\hline Total in Occ. Class & & 10 & 1 & 3 & 10 & 14 & 38 \\
\hline
\end{tabular}




\section{Frequencies}

Number of position descriptions coded $=38$

\begin{tabular}{lcc}
\hline Coding category & Present in PD & Not present in PD \\
\hline (1-1) Research planning - Develop question & $2(5)^{\mathrm{a}}$ & $36(95)^{\mathrm{a}}$ \\
(1-2) Research planning - Design study & $14(37)$ & $24(63)$ \\
(1-3) Research planning - Write proposal & $7(18)$ & $31(82)$ \\
(1-4) Research planning - Develop research program & $7(18)$ & $31(82)$ \\
(2-1) Research execution - Collect data & $15(40)$ & $23(61)$ \\
(2-2) Research execution - Database management & $5(13)$ & $33(87)$ \\
(2-3) Research execution - Conduct surveys & & $38(100)$ \\
(2-4) Research execution - Conduct studies/experiments & & $38(100)$ \\
(2-5) Research execution - Conduct inventories & $13(34)$ & $25(66)$ \\
(2-6) Research execution - Conduct monitoring & $10(26)$ & $28(74)$ \\
(2-7) Research execution - Conduct literature review & $1(3)$ & $37(97)$ \\
(3-1) Research analyses - Analyze data & $13(34)$ & $25(66)$ \\
(4-1) Research dissemination - Write reports & $10(26)$ & $28(74)$ \\
(4-2) Research dissemination - Publication & $5(13)$ & $33(87)$ \\
(4-3) Research dissemination - Presentation & $5(13)$ & $33(87)$ \\
(5-1) Research application - Management actions & $14(37)$ & $24(63)$ \\
(5-2) Research application - Policy makers & $1(3)$ & $37(97)$ \\
(5-3) Research application - Decision documents & $2(5)$ & $36(95)$ \\
(5-4) Research application - New techniques & $3(8)$ & $35(92)$ \\
(6-1) Research collaboration - Non-FWS & $6(16)$ & $32(84)$ \\
(6-2) Research collaboration - Supervision & $7(18)$ & $31(82)$ \\
(6-3) Research collaboration - Identify funding & $2(5)$ & $36(95)$ \\
(6-4) Research collaboration - Write funding proposal & $7(18)$ & $31(82)$ \\
(7-1) Knowledge/skill/ability required - Data analysis & $18(47)$ & $20(53)$ \\
(7-2) Knowledge/skill/ability required - Research methods & $21(55)$ & $17(45)$ \\
(7-3) Knowledge/skill/ability required - Statistical software & $2(5)$ & $36(95)$ \\
(7-4) Knowledge/skill/ability required - Document preparation & $10(26)$ & $28(74)$ \\
\hline
\end{tabular}

${ }^{\mathrm{a}}$ Percentages in parentheses. 


\section{Region 7}

\section{Intercoder Agreement}

\begin{tabular}{|c|c|c|c|c|}
\hline \multirow[b]{2}{*}{ Variable } & \multicolumn{2}{|c|}{$\begin{array}{c}\text { Original data } \\
\% \text { agreement }=86 \%\end{array}$} & \multicolumn{2}{|c|}{$\begin{array}{c}\text { Consensus data } \\
\% \text { agreement }=93 \%\end{array}$} \\
\hline & Kappa & Significance & Kappa & Significance \\
\hline (1-1) Planning - Research question & & - & $1.00^{\mathrm{a}}$ & .00 \\
\hline (1-2) Planning - Design & $.65^{\mathrm{a}}$ & .00 & $.77^{\mathrm{a}}$ & .00 \\
\hline (1-3) Planning - Write proposal & $.47^{\mathrm{a}}$ & .01 & $.47^{\mathrm{a}}$ & .01 \\
\hline (1-4) Planning - Develop program & $.54^{\mathrm{a}}$ & .00 & $.68^{\mathrm{a}}$ & .00 \\
\hline (2-1) Execution - Data collection & $.33^{\mathrm{a}}$ & .05 & $.66^{\mathrm{a}}$ & .00 \\
\hline (2-2) Execution - Manage data & .11 & .50 & .53 & .00 \\
\hline (2-3) Execution - Survey & & - & & - \\
\hline (2-4) Execution - Study & b & - & b & - \\
\hline (2-5) Execution - Inventory & $.61^{\mathrm{a}}$ & .00 & $.66^{\mathrm{a}}$ & .00 \\
\hline (2-6) Execution - Monitoring & $.43^{\mathrm{a}}$ & .00 & $.71^{\mathrm{a}}$ & .00 \\
\hline (2-7) Execution - Literature review & $.48^{\mathrm{a}}$ & .00 & $.65^{\mathrm{a}}$ & .00 \\
\hline (3) Analyses & $.78^{\mathrm{a}}$ & .00 & $.94^{\mathrm{a}}$ & .00 \\
\hline (4-1) Dissemination - Reports & $.56^{\mathrm{a}}$ & .00 & $.78^{\mathrm{a}}$ & .00 \\
\hline (4-2) Dissemination - Publication & $.81^{\mathrm{a}}$ & .00 & $.88^{\mathrm{a}}$ & .00 \\
\hline (4-3) Dissemination - Presentation & $.72^{\mathrm{a}}$ & .00 & $.87^{\mathrm{a}}$ & .00 \\
\hline (5-1) Application - Management & .08 & .64 & $.57^{\mathrm{a}}$ & .00 \\
\hline (5-2) Application - Policy makers & & - & & - \\
\hline (5-3) Application - Decision documents & b & - & b & - \\
\hline (5-4) Application - New approaches & .12 & .13 & $.21^{\mathrm{a}}$ & .04 \\
\hline (6-1) Collaboration - Non-FWS & $.38^{\mathrm{a}}$ & .02 & $.83^{\mathrm{a}}$ & .00 \\
\hline (6-2) Collaboration - Supervision & $.62^{\mathrm{a}}$ & .00 & $.77^{\mathrm{a}}$ & .00 \\
\hline (6-3) Collaboration - Funding & & - & & - \\
\hline (6-4) Collaboration - Grants & b & - & b & - \\
\hline (7-1) KSA - Data analysis & $.94^{\mathrm{a}}$ & .00 & $.94^{\mathrm{a}}$ & .00 \\
\hline (7-2) KSA - Methods & $.94^{\mathrm{a}}$ & .00 & $.94^{\mathrm{a}}$ & .00 \\
\hline (7-3) KSA - Software & $.35^{\mathrm{a}}$ & .01 & $.70^{\mathrm{a}}$ & .00 \\
\hline (7-4) KSA - Document & $.68^{\mathrm{a}}$ & .00 & $.88^{\mathrm{a}}$ & .00 \\
\hline
\end{tabular}

${ }^{\mathrm{a}}$ Significant at $p<.05$

${ }^{\mathrm{b}} \mathrm{Kappa}$ is not computed when at least one variable in the 2-way table is a constant. 


\section{Region 7}

\section{Latent Content Analysis Results}

Total number of position descriptions (PDs) coded for Region $7=36$

Number of PDs from published individuals $=23$

Number of PDs from non published individuals $=13$

Percentages are rounded and may not total 100.

\section{Publication Status}

Each coding category was analyzed using a Chi-square, Fisher's exact test when necessary due to sparseness, to determine if the category related to whether or not a person had published. Significant (at $p<.05)$ results were found for the following categories:

(1-2) Research planning - Design research study/data collection method

$\chi^{2}=7.88$

$p h i=.47$. This measure of the strength of the association indicates a moderately strong relationship.

Category 1-2 present in PD?

\begin{tabular}{|c|c|c|c|}
\hline & \multicolumn{3}{|c|}{ Publication status } \\
\hline & No & Yes & Total \\
\hline No & 9 & 5 & 14 \\
\hline Yes & 4 & 18 & 22 \\
\hline Total & 13 & 23 & 36 \\
\hline
\end{tabular}

Of the people who had published, $78 \%$ of them had category 1-2 content in their PDs.

Of the people who had category 1-2 content in their PDs, $82 \%$ of them had published.

(7-2) Knowledge/skill/ability required - Research methods

$\chi^{2}=6.36$

$p h i=.42$. This measure of the strength of the association indicates a moderately strong relationship.

Category 7-2 present in PD?

\begin{tabular}{|c|c|c|c|}
\hline & \multicolumn{3}{|c|}{ Publication status } \\
\hline & No & Yes & Total \\
\hline No & 9 & 6 & 15 \\
\hline Yes & 4 & 17 & 21 \\
\hline Total & 13 & 23 & 36 \\
\hline
\end{tabular}

Of the people who had published, $74 \%$ of them had category 7-2 content in their PDs.

Of the people who had category 7-2 content in their PDs, $81 \%$ of them had published. 
(7-4) Knowledge/skill/ability required - Document preparation

$\chi^{2}=8.95$

$p h i=.50$. This measure of the strength of the association indicates a strong relationship.

\begin{tabular}{crccc}
\multicolumn{2}{c}{} & \multicolumn{2}{c}{ Publication status } & Yotal \\
\cline { 3 - 5 } Category 7-4 present in PD? & No & 13 & 12 & 25 \\
& No & 0 & 11 & 11 \\
& Total & 13 & 23 & 36
\end{tabular}

Of the people who had published, $48 \%$ of them had category 7-4 content in their PDs.

Of the people who had category 7-4 content in their PDs, $100 \%$ of them had published. 
GS Level

Even when using only the GS levels with the highest numbers of PDs, there was still too much sparseness in the data to allow for analyses at the regional level. The frequencies are provided for all content categories.

\begin{tabular}{|c|c|c|c|c|c|c|c|}
\hline & & & & & & & \\
\hline $\begin{array}{l}\text { Category 1-1 } \\
\text { present in PD? }\end{array}$ & $\begin{array}{r}\text { No } \\
\text { Yes }\end{array}$ & 1 & 10 & $\begin{array}{c}17 \\
1\end{array}$ & 6 & 1 & $\begin{array}{c}35 \\
1\end{array}$ \\
\hline $\begin{array}{l}\text { Category 1-2 } \\
\text { present in PD? }\end{array}$ & $\begin{array}{r}\text { No } \\
\text { Yes }\end{array}$ & 1 & $\begin{array}{l}2 \\
8\end{array}$ & $\begin{array}{l}9 \\
9\end{array}$ & $\begin{array}{l}2 \\
4\end{array}$ & 1 & $\begin{array}{l}14 \\
22\end{array}$ \\
\hline $\begin{array}{l}\text { Category 1-3 } \\
\text { present in PD? }\end{array}$ & $\begin{array}{r}\text { No } \\
\text { Yes }\end{array}$ & 1 & $\begin{array}{l}9 \\
1\end{array}$ & 18 & $\begin{array}{l}5 \\
1\end{array}$ & 1 & $\begin{array}{c}34 \\
2\end{array}$ \\
\hline $\begin{array}{l}\text { Category 1-4 } \\
\text { present in PD? }\end{array}$ & $\begin{array}{l}\text { No } \\
\text { Yes }\end{array}$ & 1 & $\begin{array}{l}7 \\
3\end{array}$ & $\begin{array}{c}14 \\
4\end{array}$ & 6 & 1 & $\begin{array}{c}29 \\
7\end{array}$ \\
\hline $\begin{array}{l}\text { Category 2-1 } \\
\text { present in PD? }\end{array}$ & $\begin{array}{r}\text { No } \\
\text { Yes }\end{array}$ & 1 & $\begin{array}{l}4 \\
6\end{array}$ & $\begin{array}{c}10 \\
8\end{array}$ & $\begin{array}{l}3 \\
3\end{array}$ & 1 & $\begin{array}{l}19 \\
17\end{array}$ \\
\hline $\begin{array}{l}\text { Category 2-2 } \\
\text { present in PD? }\end{array}$ & $\begin{array}{r}\text { No } \\
\text { Yes }\end{array}$ & 1 & $\begin{array}{l}9 \\
1\end{array}$ & $\begin{array}{c}17 \\
1\end{array}$ & $\begin{array}{l}5 \\
1\end{array}$ & 1 & $\begin{array}{c}32 \\
4\end{array}$ \\
\hline $\begin{array}{l}\text { Category 2-3 } \\
\text { present in PD? }\end{array}$ & $\begin{array}{r}\text { No } \\
\text { Yes }\end{array}$ & 1 & 10 & 18 & 6 & 1 & $\begin{array}{c}36 \\
0\end{array}$ \\
\hline $\begin{array}{l}\text { Category 2-4 } \\
\text { present in PD? }\end{array}$ & $\begin{array}{r}\text { No } \\
\text { Yes }\end{array}$ & 1 & 10 & 18 & 6 & 1 & $\begin{array}{c}36 \\
0\end{array}$ \\
\hline $\begin{array}{l}\text { Category 2-5 } \\
\text { present in PD? }\end{array}$ & $\begin{array}{r}\text { No } \\
\text { Yes }\end{array}$ & 1 & $\begin{array}{l}1 \\
9\end{array}$ & $\begin{array}{c}6 \\
12\end{array}$ & $\begin{array}{l}3 \\
3\end{array}$ & 1 & $\begin{array}{l}11 \\
25\end{array}$ \\
\hline $\begin{array}{l}\text { Category 2-6 } \\
\text { present in PD? }\end{array}$ & $\begin{array}{r}\text { No } \\
\text { Yes }\end{array}$ & 1 & $\begin{array}{l}6 \\
4\end{array}$ & $\begin{array}{c}15 \\
3\end{array}$ & 6 & 1 & $\begin{array}{c}29 \\
7\end{array}$ \\
\hline $\begin{array}{l}\text { Category 2-7 } \\
\text { present in PD? }\end{array}$ & $\begin{array}{r}\text { No } \\
\text { Yes }\end{array}$ & 1 & 10 & $\begin{array}{c}17 \\
1\end{array}$ & 6 & 1 & $\begin{array}{c}35 \\
1\end{array}$ \\
\hline $\begin{array}{l}\text { Category 3-1 } \\
\text { present in PD? }\end{array}$ & $\begin{array}{r}\text { No } \\
\text { Yes }\end{array}$ & 1 & $\begin{array}{l}5 \\
5\end{array}$ & $\begin{array}{c}7 \\
11\end{array}$ & $\begin{array}{l}3 \\
3\end{array}$ & 1 & $\begin{array}{l}16 \\
20\end{array}$ \\
\hline $\begin{array}{l}\text { Category 4-1 } \\
\text { present in PD? }\end{array}$ & $\begin{array}{r}\text { No } \\
\text { Yes }\end{array}$ & 1 & $\begin{array}{l}7 \\
3\end{array}$ & $\begin{array}{c}7 \\
11\end{array}$ & $\begin{array}{l}4 \\
2\end{array}$ & 1 & $\begin{array}{l}20 \\
16\end{array}$ \\
\hline $\begin{array}{l}\text { Category 4-2 } \\
\text { present in PD? }\end{array}$ & $\begin{array}{r}\text { No } \\
\text { Yes }\end{array}$ & 1 & $\begin{array}{l}7 \\
3\end{array}$ & $\begin{array}{c}13 \\
5\end{array}$ & $\begin{array}{l}4 \\
2\end{array}$ & 1 & $\begin{array}{l}25 \\
11\end{array}$ \\
\hline $\begin{array}{l}\text { Category 4-3 } \\
\text { present in PD? }\end{array}$ & $\begin{array}{r}\text { No } \\
\text { Yes }\end{array}$ & 1 & 10 & $\begin{array}{c}14 \\
4\end{array}$ & $\begin{array}{l}5 \\
1\end{array}$ & 1 & $\begin{array}{c}31 \\
5\end{array}$ \\
\hline $\begin{array}{l}\text { Category 5-1 } \\
\text { present in PD? }\end{array}$ & $\begin{array}{r}\text { No } \\
\text { Yes }\end{array}$ & 1 & $\begin{array}{l}3 \\
7\end{array}$ & $\begin{array}{l}9 \\
9\end{array}$ & $\begin{array}{l}2 \\
4\end{array}$ & 1 & $\begin{array}{l}16 \\
20\end{array}$ \\
\hline $\begin{array}{l}\text { Category 5-2 } \\
\text { present in PD? }\end{array}$ & $\begin{array}{r}\text { No } \\
\text { Yes }\end{array}$ & 1 & 10 & $\begin{array}{c}16 \\
2\end{array}$ & 6 & 1 & $\begin{array}{c}34 \\
2\end{array}$ \\
\hline
\end{tabular}




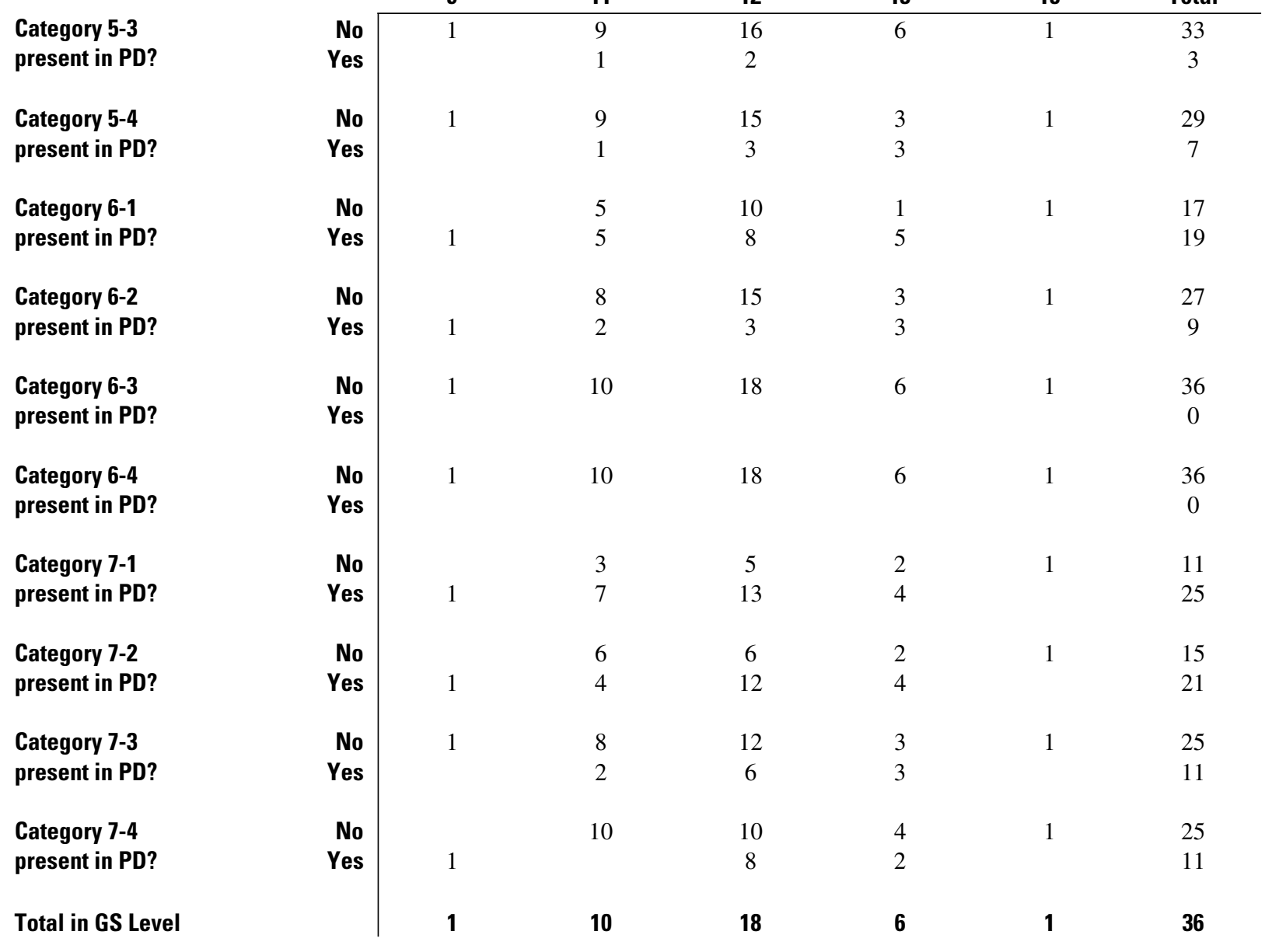


Even when using only the occupational classifications with the highest numbers of PDs, there was still too much sparseness in the data to allow for analyses at the regional level. The frequencies are provided for all content categories.

\begin{tabular}{|c|c|c|c|c|c|c|c|c|c|}
\hline & & & & & Ipatio & Issific & & & \\
\hline & & 193 & 401 & 480 & 482 & 485 & 486 & 1530 & Total \\
\hline $\begin{array}{l}\text { Category 1-1 } \\
\text { present? }\end{array}$ & $\begin{array}{r}\text { No } \\
\text { Yes }\end{array}$ & 1 & 10 & 1 & 2 & 2 & $\begin{array}{c}18 \\
1\end{array}$ & 1 & $\begin{array}{c}35 \\
1\end{array}$ \\
\hline $\begin{array}{l}\text { Category 1-2 } \\
\text { present? }\end{array}$ & $\begin{array}{l}\text { No } \\
\text { Yes }\end{array}$ & 1 & $\begin{array}{l}2 \\
8\end{array}$ & 1 & 2 & 2 & $\begin{array}{c}9 \\
10\end{array}$ & 1 & $\begin{array}{l}14 \\
22\end{array}$ \\
\hline $\begin{array}{l}\text { Category 1-3 } \\
\text { present? }\end{array}$ & $\begin{array}{l}\text { No } \\
\text { Yes }\end{array}$ & 1 & 10 & 1 & $\begin{array}{l}1 \\
1\end{array}$ & 2 & $\begin{array}{c}18 \\
1\end{array}$ & 1 & $\begin{array}{c}34 \\
2\end{array}$ \\
\hline $\begin{array}{l}\text { Category 1-4 } \\
\text { present? }\end{array}$ & $\begin{array}{r}\text { No } \\
\text { Yes }\end{array}$ & 1 & $\begin{array}{l}9 \\
1\end{array}$ & 1 & 2 & 2 & $\begin{array}{c}13 \\
6\end{array}$ & 1 & $\begin{array}{c}29 \\
7\end{array}$ \\
\hline $\begin{array}{l}\text { Category 2-1 } \\
\text { present? }\end{array}$ & $\begin{array}{l}\text { No } \\
\text { Yes }\end{array}$ & 1 & $\begin{array}{l}2 \\
8\end{array}$ & 1 & $\begin{array}{l}1 \\
1\end{array}$ & 2 & $\begin{array}{c}13 \\
6\end{array}$ & 1 & $\begin{array}{l}19 \\
17\end{array}$ \\
\hline $\begin{array}{l}\text { Category 2-2 } \\
\text { present? }\end{array}$ & $\begin{array}{l}\text { No } \\
\text { Yes }\end{array}$ & 1 & 10 & 1 & 2 & 2 & $\begin{array}{c}16 \\
3\end{array}$ & 1 & $\begin{array}{c}32 \\
4\end{array}$ \\
\hline $\begin{array}{l}\text { Category 2-3 } \\
\text { present? }\end{array}$ & $\begin{array}{l}\text { No } \\
\text { Yes }\end{array}$ & 1 & 10 & 1 & 2 & 2 & 19 & 1 & $\begin{array}{c}36 \\
0\end{array}$ \\
\hline $\begin{array}{l}\text { Category 2-4 } \\
\text { present? }\end{array}$ & $\begin{array}{l}\text { No } \\
\text { Yes }\end{array}$ & 1 & 10 & 1 & 2 & 2 & 19 & 1 & $\begin{array}{c}36 \\
0\end{array}$ \\
\hline $\begin{array}{l}\text { Category 2-5 } \\
\text { present? }\end{array}$ & $\begin{array}{l}\text { No } \\
\text { Yes }\end{array}$ & 1 & $\begin{array}{l}3 \\
7\end{array}$ & 1 & 2 & 2 & $\begin{array}{c}4 \\
15\end{array}$ & 1 & $\begin{array}{l}11 \\
25\end{array}$ \\
\hline $\begin{array}{l}\text { Category 2-6 } \\
\text { present? }\end{array}$ & $\begin{array}{l}\text { No } \\
\text { Yes }\end{array}$ & 1 & 10 & 1 & 2 & 2 & $\begin{array}{c}12 \\
7\end{array}$ & 1 & $\begin{array}{c}29 \\
7\end{array}$ \\
\hline $\begin{array}{l}\text { Category 2-7 } \\
\text { present? }\end{array}$ & $\begin{array}{l}\text { No } \\
\text { Yes }\end{array}$ & 1 & $\begin{array}{l}9 \\
1\end{array}$ & 1 & 2 & 2 & 19 & 1 & $\begin{array}{c}35 \\
1\end{array}$ \\
\hline $\begin{array}{l}\text { Category 3-1 } \\
\text { present? }\end{array}$ & $\begin{array}{l}\text { No } \\
\text { Yes }\end{array}$ & 1 & $\begin{array}{l}4 \\
6\end{array}$ & 1 & 2 & 2 & $\begin{array}{c}8 \\
11\end{array}$ & 1 & $\begin{array}{l}16 \\
20\end{array}$ \\
\hline $\begin{array}{l}\text { Category 4-1 } \\
\text { present? }\end{array}$ & $\begin{array}{l}\text { No } \\
\text { Yes }\end{array}$ & 1 & $\begin{array}{l}3 \\
7\end{array}$ & 1 & 2 & 2 & $\begin{array}{c}11 \\
8\end{array}$ & 1 & $\begin{array}{l}20 \\
16\end{array}$ \\
\hline $\begin{array}{l}\text { Category 4-2 } \\
\text { present? }\end{array}$ & $\begin{array}{l}\text { No } \\
\text { Yes }\end{array}$ & 1 & 10 & 1 & 2 & 2 & $\begin{array}{c}9 \\
10\end{array}$ & 1 & $\begin{array}{l}25 \\
11\end{array}$ \\
\hline $\begin{array}{l}\text { Category 4-3 } \\
\text { present? }\end{array}$ & $\begin{array}{r}\text { No } \\
\text { Yes }\end{array}$ & 1 & $\begin{array}{l}8 \\
2\end{array}$ & 1 & 2 & 2 & $\begin{array}{c}17 \\
2\end{array}$ & 1 & $\begin{array}{c}31 \\
5\end{array}$ \\
\hline $\begin{array}{l}\text { Category 5-1 } \\
\text { present? }\end{array}$ & $\begin{array}{l}\text { No } \\
\text { Yes }\end{array}$ & 1 & $\begin{array}{l}3 \\
7\end{array}$ & 1 & 2 & 2 & $\begin{array}{c}9 \\
10\end{array}$ & 1 & $\begin{array}{l}16 \\
20\end{array}$ \\
\hline $\begin{array}{l}\text { Category 5-2 } \\
\text { present? }\end{array}$ & $\begin{array}{r}\text { No } \\
\text { Yes }\end{array}$ & 1 & 10 & 1 & 2 & 2 & $\begin{array}{c}17 \\
2\end{array}$ & 1 & $\begin{array}{c}34 \\
2\end{array}$ \\
\hline
\end{tabular}

Occupational classification 


\begin{tabular}{|c|c|c|c|c|c|c|c|c|c|}
\hline & & & & & upatio & ssific & & & \\
\hline & & 193 & 401 & 480 & 482 & 485 & 486 & 1530 & Total \\
\hline Category 5-3 & No & 1 & 9 & 1 & 2 & 2 & 17 & 1 & 33 \\
\hline present? & Yes & & 1 & & & & 2 & & 3 \\
\hline Category 5-4 & No & 1 & 9 & 1 & 2 & 2 & 14 & & 29 \\
\hline present? & Yes & & 1 & & & & 5 & 1 & 7 \\
\hline Category 6-1 & No & & 8 & 1 & 2 & & 6 & & 17 \\
\hline present? & Yes & 1 & 2 & & & 2 & 13 & 1 & 19 \\
\hline Category 6-2 & No & 1 & 10 & 1 & 1 & 1 & 13 & & 27 \\
\hline present? & Yes & & & & 1 & 1 & 6 & 1 & 9 \\
\hline $\begin{array}{l}\text { Category 6-3 } \\
\text { present? }\end{array}$ & $\begin{array}{r}\text { No } \\
\text { Yes }\end{array}$ & 1 & 10 & 1 & 2 & 2 & 19 & 1 & $\begin{array}{c}36 \\
0\end{array}$ \\
\hline $\begin{array}{l}\text { Category 6-4 } \\
\text { present? }\end{array}$ & $\begin{array}{r}\text { No } \\
\text { Yes }\end{array}$ & 1 & 10 & 1 & 2 & 2 & 19 & 1 & $\begin{array}{c}36 \\
0\end{array}$ \\
\hline Category 7-1 & No & 1 & 4 & 1 & 1 & 2 & 2 & & 11 \\
\hline present? & Yes & & 6 & & 1 & & 17 & 1 & 25 \\
\hline Category 7-2 & No & 1 & 2 & 1 & 2 & 2 & 7 & & 15 \\
\hline present? & Yes & & 8 & & & & 12 & 1 & 21 \\
\hline Category 7-3 & No & 1 & 6 & 1 & 2 & 2 & 12 & 1 & 25 \\
\hline present? & Yes & & 4 & & & & 7 & & 11 \\
\hline Category 7-4 & No & 1 & 6 & 1 & 2 & 2 & 12 & 1 & 25 \\
\hline present? & Yes & & 4 & & & & 7 & & 11 \\
\hline $\begin{array}{l}\text { Total in Occ. } \\
\text { Class }\end{array}$ & & 1 & 10 & 1 & 2 & 2 & 19 & 1 & 36 \\
\hline
\end{tabular}




\section{Frequencies}

Number of position descriptions coded $=36$

\begin{tabular}{lcc}
\hline Coding category & Present in PD & Not present in PD \\
\hline (1-1) Research planning - Develop question & $1(3)^{\mathrm{a}}$ & $35(97)^{\mathrm{a}}$ \\
(1-2) Research planning - Design study & $22(61)$ & $14(39)$ \\
(1-3) Research planning - Write proposal & $2(6)$ & $34(94)$ \\
(1-4) Research planning - Develop research program & $7(19)$ & $29(81)$ \\
(2-1) Research execution - Collect data & $17(47)$ & $19(53)$ \\
(2-2) Research execution - Database management & $4(11)$ & $32(89)$ \\
(2-3) Research execution - Conduct surveys & & $36(100)$ \\
(2-4) Research execution - Conduct studies/experiments & & $36(100)$ \\
(2-5) Research execution - Conduct inventories & $25(69)$ & $11(31)$ \\
(2-6) Research execution - Conduct monitoring & $7(19)$ & $29(81)$ \\
(2-7) Research execution - Conduct literature review & $1(3)$ & $35(97)$ \\
(3-1) Research analyses - Analyze data & $20(56)$ & $16(44)$ \\
(4-1) Research dissemination - Write reports & $16(44)$ & $20(56)$ \\
(4-2) Research dissemination - Publication & $11(31)$ & $25(69)$ \\
(4-3) Research dissemination - Presentation & $5(14)$ & $31(86)$ \\
(5-1) Research application - Management actions & $20(56)$ & $16(44)$ \\
(5-2) Research application - Policy makers & $2(6)$ & $34(94)$ \\
(5-3) Research application - Decision documents & $3(8)$ & $33(92)$ \\
(5-4) Research application - New techniques & $7(19)$ & $29(81)$ \\
(6-1) Research collaboration - Non-FWS & $19(53)$ & $17(47)$ \\
(6-2) Research collaboration - Supervision & $9(25)$ & $27(75)$ \\
(6-3) Research collaboration - Identify funding & & $36(100)$ \\
(6-4) Research collaboration - Write funding proposal & $25(69)$ & $36(100)$ \\
(7-1) Knowledge/skill/ability required - Data analysis & $21(58)$ & $11(31)$ \\
(7-2) Knowledge/skill/ability required - Research methods & $11(31)$ & $25(69)$ \\
(7-3) Knowledge/skill/ability required - Statistical software & $11(31)$ & $25(69)$ \\
(7-4) Knowledge/skill/ability required - Document preparation & & \\
\hline
\end{tabular}

${ }^{\mathrm{a}}$ Percentages in parentheses. 


\section{Region 9}

\section{Intercoder Agreement}

\begin{tabular}{|c|c|c|c|c|}
\hline \multirow[b]{2}{*}{ Variable } & \multicolumn{2}{|c|}{$\begin{array}{c}\text { Original data } \\
\% \text { agreement }=94\end{array}$} & \multicolumn{2}{|c|}{$\begin{array}{c}\text { Consensus data } \\
\text { No consensus needed }\end{array}$} \\
\hline & Kappa & Significance & Kappa & Significance \\
\hline (1-1) Planning - Research question & & - & & \\
\hline (1-2) Planning - Design & $.58^{\mathrm{a}}$ & .00 & & \\
\hline (1-3) Planning - Write proposal & & - & & \\
\hline (1-4) Planning - Develop program & $.64^{\mathrm{a}}$ & .00 & & \\
\hline (2-1) Execution - Data collection & $.5^{\mathrm{a}}$ & .00 & & \\
\hline (2-2) Execution - Manage data & $1.00^{\mathrm{a}}$ & .00 & & \\
\hline (2-3) Execution - Survey & $\mathrm{b}$ & - & & \\
\hline (2-4) Execution - Study & b & - & & \\
\hline (2-5) Execution - Inventory & $.84^{\mathrm{a}}$ & .00 & & \\
\hline (2-6) Execution - Monitoring & $.30^{\mathrm{a}}$ & .01 & & \\
\hline (2-7) Execution - Literature review & -.04 & .80 & & \\
\hline (3) Analyses & $.47^{\mathrm{a}}$ & .00 & & \\
\hline (4-1) Dissemination - Reports & $.39^{\mathrm{a}}$ & .04 & & \\
\hline (4-2) Dissemination - Publication &.-03 & .86 & & \\
\hline (4-3) Dissemination - Presentation & & - & & \\
\hline (5-1) Application - Management & $.40^{\mathrm{a}}$ & .02 & & \\
\hline (5-2) Application - Policy makers & -.03 & .86 & & \\
\hline (5-3) Application - Decision documents & & - & & \\
\hline (5-4) Application - New approaches & $.68^{\mathrm{a}}$ & .00 & & \\
\hline (6-1) Collaboration - Non-FWS & $.59^{\mathrm{a}}$ & .00 & & \\
\hline (6-2) Collaboration - Supervision & $.72^{\mathrm{a}}$ & .00 & & \\
\hline (6-3) Collaboration - Funding & & - & & \\
\hline (6-4) Collaboration - Grants & $\mathrm{b}$ & - & & \\
\hline (7-1) KSA - Data analysis & $.93^{\mathrm{a}}$ & .00 & & \\
\hline (7-2) KSA - Methods & $.82^{\mathrm{a}}$ & .00 & & \\
\hline (7-3) KSA - Software & $.48^{\mathrm{a}}$ & .00 & & \\
\hline (7-4) KSA - Document & $1.00^{\mathrm{a}}$ & .00 & & \\
\hline
\end{tabular}

${ }^{\mathrm{a}}$ Significant at $p<.05$

${ }^{\mathrm{b}} \mathrm{Kappa}$ is not computed when at least one variable in the 2-way table is a constant. 


\section{Region 9}

\section{Latent Content Analysis Results}

Total number of position descriptions (PDs) coded for Region $9=35$

Number of PDs from published individuals $=16$

Number of PDs from non published individuals $=19$

Percentages are rounded and may not total 100.

\section{Publication Status}

Each coding category was analyzed using a Chi-square, Fisher's exact test when necessary due to sparseness, to determine if the category related to whether or not a person had published. Significant (at $p<.05)$ results were found for the following categories:

(2-5) Research execution - Conduct inventories/field studies

$\chi^{2}=5.64$

$p h i=.40$. This measure of the strength of the association indicates a moderately strong relationship.

\section{Category 2-5 present in PD?}

\begin{tabular}{|c|c|c|c|}
\hline & \multicolumn{3}{|c|}{ Publication status } \\
\hline & No & Yes & Total \\
\hline No & 18 & 10 & 28 \\
\hline Yes & 1 & 6 & 7 \\
\hline Total & 19 & 16 & 35 \\
\hline
\end{tabular}

Of the people who had published, $38 \%$ of them had category 2-5 content in their PDs.

Of the people who had category $2-5$ content in their PDs, $86 \%$ of them had published.

(5-1) Research application - Use research-based information to evaluate or inform management actions

$\chi^{2}=11.06$

$p h i=.56$. This measure of the strength of the association indicates a strong relationship.

Category 5-1 present in PD?

\begin{tabular}{r|ccc}
\multicolumn{1}{c}{} & \multicolumn{1}{c}{$\begin{array}{c}\text { Publication status } \\
\text { Yes }\end{array}$} & Total \\
\cline { 2 - 4 } No & No & 7 & 25 \\
Yes & 18 & 9 & 10 \\
Total & 1 & 16 & 35
\end{tabular}

Of the people who had published, 56\% of them had category 5-1 content in their PDs.

Of the people who had category 5-1 content in their PDs, 90\% of them had published. 
(6-1) Research collaboration - Collaborate with non-FWS personnel on research projects

$\chi^{2}=6.93$

$p h i=.45$. This measure of the strength of the association indicates a moderately strong relationship.

\section{Category 6-1 present in PD?}

\begin{tabular}{r|ccc}
\multicolumn{2}{c}{} & \multicolumn{2}{c}{ Publication status } \\
\multicolumn{1}{c}{} & No & Yes & Total \\
\cline { 2 - 4 } No & 19 & 11 & 30 \\
Yes & 0 & 5 & 5 \\
Total & 19 & 16 & 35
\end{tabular}

Of the people who had published, $31 \%$ of them had category 6-1 content in their PDs.

Of the people who had category 6-1 content in their PDs, $100 \%$ of them had published.

(7-1) Knowledge/skill/ability required - Statistical data analysis

$\chi^{2}=4.72$

$p h i=.37$. This measure of the strength of the association indicates a moderate relationship.

\section{Category 7-1 present in PD?}

\begin{tabular}{|c|c|c|c|}
\hline & & tion & \\
\hline & No & Yes & Total \\
\hline No & 16 & 8 & 24 \\
\hline Yes & 3 & 8 & 11 \\
\hline Total & 19 & 16 & 35 \\
\hline
\end{tabular}

Of the people who had published, 50\% of them had category 7-1 content in their PDs.

Of the people who had category 7-1 content in their PDs, $73 \%$ of them had published.

(7-2) Knowledge/skill/ability required - Research methods

$\chi^{2}=4.64$

$p h i=.36$. This measure of the strength of the association indicates a moderate relationship.

\section{Category 7-2 present in PD?}

\begin{tabular}{|c|c|c|c|}
\hline & & ation & \\
\hline & No & Yes & Total \\
\hline No & 14 & 6 & 20 \\
\hline Yes & 5 & 10 & 15 \\
\hline Total & 19 & 16 & 35 \\
\hline
\end{tabular}

Of the people who had published, 63\% of them had category 7-2 content in their PDs.

Of the people who had category 7-2 content in their PDs, $67 \%$ of them had published. 
GS Level

Even when using only the GS levels with the highest numbers of PDs, there was still too much sparseness in the data to allow for analyses at the regional level. The frequencies are provided for all content categories.

\begin{tabular}{|c|c|c|c|c|c|c|c|}
\hline & & 11 & 12 & 13 & 14 & 15 & Iotal \\
\hline $\begin{array}{l}\text { Category 1-1 } \\
\text { present in PD? }\end{array}$ & $\begin{array}{r}\text { No } \\
\text { Yes }\end{array}$ & 2 & 6 & 20 & 5 & 2 & $\begin{array}{c}35 \\
0\end{array}$ \\
\hline $\begin{array}{l}\text { Category 1-2 } \\
\text { present in PD? }\end{array}$ & $\begin{array}{r}\text { No } \\
\text { Yes }\end{array}$ & 2 & $\begin{array}{l}5 \\
1\end{array}$ & $\begin{array}{c}15 \\
5\end{array}$ & 5 & 2 & $\begin{array}{c}29 \\
6\end{array}$ \\
\hline $\begin{array}{l}\text { Category 1-3 } \\
\text { present in PD? }\end{array}$ & $\begin{array}{r}\text { No } \\
\text { Yes }\end{array}$ & 2 & 6 & 20 & 5 & 2 & $\begin{array}{c}35 \\
0\end{array}$ \\
\hline $\begin{array}{l}\text { Category 1-4 } \\
\text { present in PD? }\end{array}$ & $\begin{array}{r}\text { No } \\
\text { Yes }\end{array}$ & 2 & 6 & $\begin{array}{c}18 \\
2\end{array}$ & 5 & 2 & $\begin{array}{c}33 \\
2\end{array}$ \\
\hline $\begin{array}{l}\text { Category 2-1 } \\
\text { present in PD? }\end{array}$ & $\begin{array}{r}\text { No } \\
\text { Yes }\end{array}$ & $\begin{array}{l}1 \\
1\end{array}$ & $\begin{array}{l}5 \\
1\end{array}$ & $\begin{array}{c}16 \\
4\end{array}$ & $\begin{array}{l}4 \\
1\end{array}$ & 2 & $\begin{array}{c}28 \\
7\end{array}$ \\
\hline $\begin{array}{l}\text { Category 2-2 } \\
\text { present in PD? }\end{array}$ & $\begin{array}{r}\text { No } \\
\text { Yes }\end{array}$ & 2 & 6 & $\begin{array}{c}19 \\
1\end{array}$ & 5 & 2 & $\begin{array}{c}34 \\
1\end{array}$ \\
\hline $\begin{array}{l}\text { Category 2-3 } \\
\text { present in PD? }\end{array}$ & $\begin{array}{r}\text { No } \\
\text { Yes }\end{array}$ & 2 & 6 & $\begin{array}{c}19 \\
1\end{array}$ & 5 & 2 & $\begin{array}{c}34 \\
1\end{array}$ \\
\hline $\begin{array}{l}\text { Category 2-4 } \\
\text { present in PD? }\end{array}$ & $\begin{array}{r}\text { No } \\
\text { Yes }\end{array}$ & 2 & 6 & 20 & 5 & 2 & $\begin{array}{c}35 \\
0\end{array}$ \\
\hline $\begin{array}{l}\text { Category 2-5 } \\
\text { present in PD? }\end{array}$ & $\begin{array}{r}\text { No } \\
\text { Yes }\end{array}$ & $\begin{array}{l}1 \\
1\end{array}$ & 6 & $\begin{array}{c}15 \\
5\end{array}$ & $\begin{array}{l}4 \\
1\end{array}$ & 2 & $\begin{array}{c}28 \\
7\end{array}$ \\
\hline $\begin{array}{l}\text { Category 2-6 } \\
\text { present in PD? }\end{array}$ & $\begin{array}{r}\text { No } \\
\text { Yes }\end{array}$ & 2 & 6 & $\begin{array}{c}16 \\
4\end{array}$ & $\begin{array}{l}4 \\
1\end{array}$ & 2 & $\begin{array}{c}30 \\
5\end{array}$ \\
\hline $\begin{array}{l}\text { Category 2-7 } \\
\text { present in PD? }\end{array}$ & $\begin{array}{r}\text { No } \\
\text { Yes }\end{array}$ & 2 & 6 & $\begin{array}{c}19 \\
1\end{array}$ & 5 & 2 & $\begin{array}{c}34 \\
1\end{array}$ \\
\hline $\begin{array}{l}\text { Category 3-1 } \\
\text { present in PD? }\end{array}$ & $\begin{array}{r}\text { No } \\
\text { Yes }\end{array}$ & 2 & $\begin{array}{l}5 \\
1\end{array}$ & $\begin{array}{c}15 \\
5\end{array}$ & 5 & 2 & $\begin{array}{c}29 \\
6\end{array}$ \\
\hline $\begin{array}{l}\text { Category 4-1 } \\
\text { present in PD? }\end{array}$ & $\begin{array}{r}\text { No } \\
\text { Yes }\end{array}$ & 2 & 6 & $\begin{array}{c}18 \\
2\end{array}$ & 5 & 2 & $\begin{array}{c}33 \\
2\end{array}$ \\
\hline $\begin{array}{l}\text { Category 4-2 } \\
\text { present in PD? }\end{array}$ & $\begin{array}{r}\text { No } \\
\text { Yes }\end{array}$ & 2 & 6 & $\begin{array}{c}19 \\
1\end{array}$ & 5 & 2 & $\begin{array}{c}34 \\
1\end{array}$ \\
\hline $\begin{array}{l}\text { Category 4-3 } \\
\text { present in PD? }\end{array}$ & $\begin{array}{r}\text { No } \\
\text { Yes }\end{array}$ & 2 & 6 & 20 & 5 & 2 & $\begin{array}{c}35 \\
0\end{array}$ \\
\hline $\begin{array}{l}\text { Category 5-1 } \\
\text { present in PD? }\end{array}$ & $\begin{array}{r}\text { No } \\
\text { Yes }\end{array}$ & $\begin{array}{l}1 \\
1\end{array}$ & $\begin{array}{l}5 \\
1\end{array}$ & $\begin{array}{c}14 \\
6\end{array}$ & $\begin{array}{l}3 \\
2\end{array}$ & 2 & $\begin{array}{l}25 \\
10\end{array}$ \\
\hline $\begin{array}{l}\text { Category 5-2 } \\
\text { present in PD? }\end{array}$ & $\begin{array}{r}\text { No } \\
\text { Yes }\end{array}$ & 2 & 6 & $\begin{array}{c}19 \\
1\end{array}$ & 5 & 2 & $\begin{array}{c}34 \\
1\end{array}$ \\
\hline
\end{tabular}


Category 5-3

present in PD?

Category 5-4

present in PD?

Category 6-1

present in PD?

Category 6-2

present in PD?

Category 6-3

present in PD?

Category 6-4

present in PD?

Category 7-1

present in PD?

Category 7-2

present in PD?

Category 7-3

present in PD?

Category 7-4

present in PD?

Total in GS Level

GS level

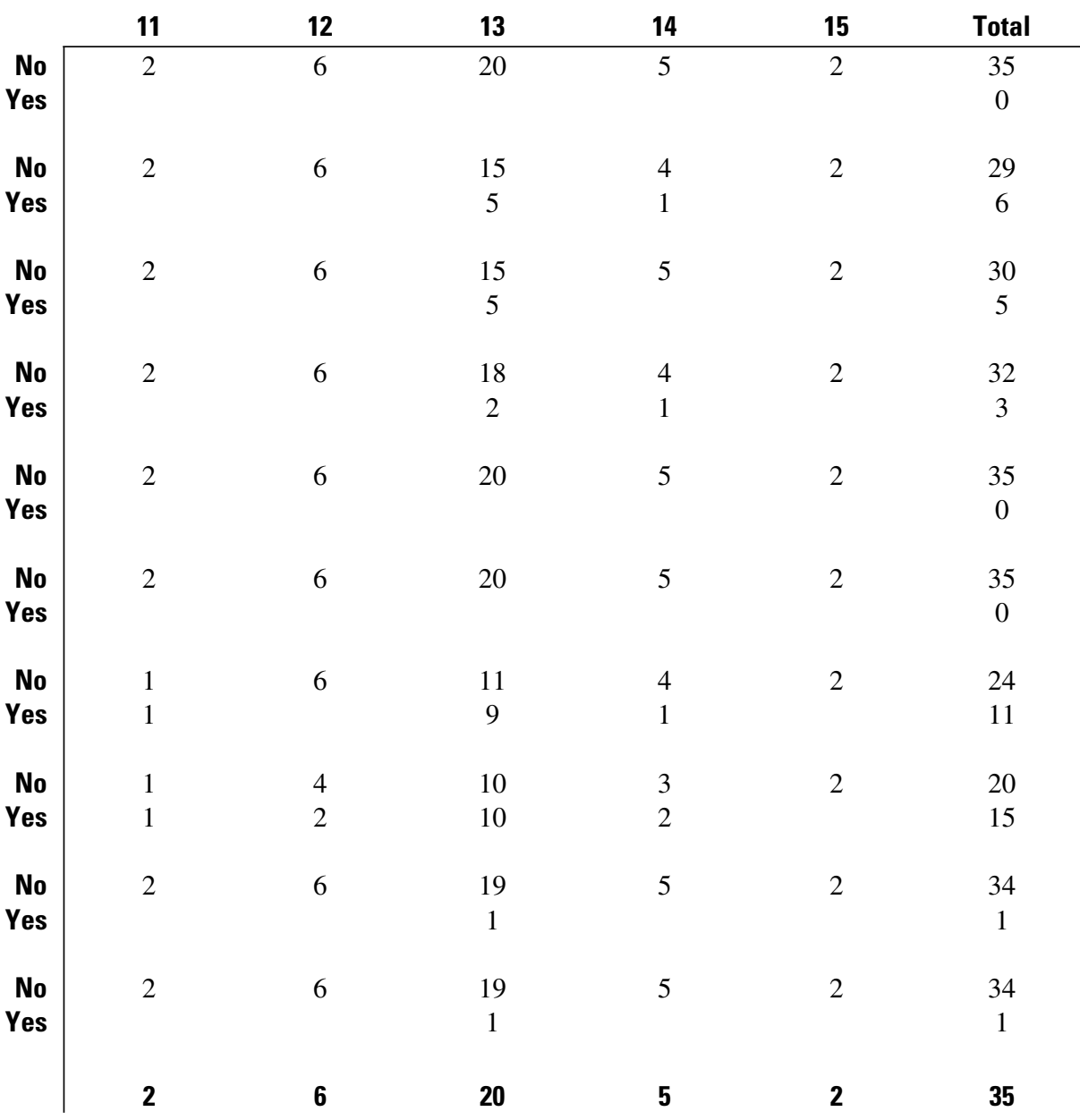


Even when using only the occupational classifications with the highest numbers of PDs, there was still too much sparseness in the data to allow for analyses at the regional level. The frequencies are provided for all content categories.

\begin{tabular}{|c|c|c|c|c|c|c|c|c|c|c|c|}
\hline & & & & & & & & & & & \\
\hline $\begin{array}{l}\text { Category 1-1 } \\
\text { present? }\end{array}$ & $\begin{array}{r}\text { No } \\
\text { Yes }\end{array}$ & 1 & 1 & 6 & 2 & 5 & 2 & 15 & 1 & 2 & $\begin{array}{c}35 \\
0\end{array}$ \\
\hline $\begin{array}{l}\text { Category 1-2 } \\
\text { present? }\end{array}$ & $\begin{array}{r}\text { No } \\
\text { Yes }\end{array}$ & 1 & 1 & 6 & 2 & $\begin{array}{l}4 \\
1\end{array}$ & 2 & $\begin{array}{c}11 \\
4\end{array}$ & 1 & $\begin{array}{l}1 \\
1\end{array}$ & $\begin{array}{c}29 \\
6\end{array}$ \\
\hline $\begin{array}{l}\text { Category 1-3 } \\
\text { present? }\end{array}$ & $\begin{array}{r}\text { No } \\
\text { Yes }\end{array}$ & 1 & 1 & 6 & 2 & 5 & 2 & 15 & 1 & 2 & $\begin{array}{c}35 \\
0\end{array}$ \\
\hline $\begin{array}{l}\text { Category 1-4 } \\
\text { present? }\end{array}$ & $\begin{array}{r}\text { No } \\
\text { Yes }\end{array}$ & 1 & 1 & $\begin{array}{l}5 \\
1\end{array}$ & 2 & 5 & 2 & 15 & 1 & 2 & $\begin{array}{c}33 \\
2\end{array}$ \\
\hline $\begin{array}{l}\text { Category 2-1 } \\
\text { present? }\end{array}$ & $\begin{array}{r}\text { No } \\
\text { Yes }\end{array}$ & 1 & 1 & 6 & 2 & $\begin{array}{l}4 \\
1\end{array}$ & 2 & $\begin{array}{c}10 \\
5\end{array}$ & 1 & $\begin{array}{l}1 \\
1\end{array}$ & $\begin{array}{c}28 \\
7\end{array}$ \\
\hline $\begin{array}{l}\text { Category 2-2 } \\
\text { present? }\end{array}$ & $\begin{array}{r}\text { No } \\
\text { Yes }\end{array}$ & 1 & 1 & 6 & 2 & $\begin{array}{l}4 \\
1\end{array}$ & 2 & 15 & 1 & 2 & $\begin{array}{c}34 \\
1\end{array}$ \\
\hline $\begin{array}{l}\text { Category 2-3 } \\
\text { present? }\end{array}$ & $\begin{array}{r}\text { No } \\
\text { Yes }\end{array}$ & 1 & 1 & 6 & 2 & 5 & 2 & $\begin{array}{c}14 \\
1\end{array}$ & 1 & 2 & $\begin{array}{c}34 \\
1\end{array}$ \\
\hline $\begin{array}{l}\text { Category 2-4 } \\
\text { present? }\end{array}$ & $\begin{array}{r}\text { No } \\
\text { Yes }\end{array}$ & 1 & 1 & 6 & 2 & 5 & 2 & 15 & 1 & 2 & $\begin{array}{c}35 \\
0\end{array}$ \\
\hline $\begin{array}{l}\text { Category 2-5 } \\
\text { present? }\end{array}$ & $\begin{array}{r}\text { No } \\
\text { Yes }\end{array}$ & 1 & 1 & 6 & 2 & 5 & 2 & $\begin{array}{l}8 \\
7\end{array}$ & 1 & 2 & $\begin{array}{c}28 \\
7\end{array}$ \\
\hline $\begin{array}{l}\text { Category 2-6 } \\
\text { present? }\end{array}$ & $\begin{array}{r}\text { No } \\
\text { Yes }\end{array}$ & 1 & 1 & 6 & 2 & 5 & 2 & $\begin{array}{c}11 \\
4\end{array}$ & 1 & $\begin{array}{l}1 \\
1\end{array}$ & $\begin{array}{c}30 \\
5\end{array}$ \\
\hline $\begin{array}{l}\text { Category 2-7 } \\
\text { present? }\end{array}$ & $\begin{array}{r}\text { No } \\
\text { Yes }\end{array}$ & 1 & 1 & 6 & 2 & 5 & 2 & 15 & 1 & 2 & $\begin{array}{c}34 \\
1\end{array}$ \\
\hline $\begin{array}{l}\text { Category 3-1 } \\
\text { present? }\end{array}$ & $\begin{array}{r}\text { No } \\
\text { Yes }\end{array}$ & 1 & 1 & 6 & 2 & $\begin{array}{l}3 \\
2\end{array}$ & 2 & $\begin{array}{c}12 \\
3\end{array}$ & 1 & $\begin{array}{l}1 \\
1\end{array}$ & $\begin{array}{c}29 \\
6\end{array}$ \\
\hline $\begin{array}{l}\text { Category 4-1 } \\
\text { present? }\end{array}$ & $\begin{array}{r}\text { No } \\
\text { Yes }\end{array}$ & 1 & 1 & 6 & 2 & $\begin{array}{l}4 \\
1\end{array}$ & 2 & 15 & 1 & $\begin{array}{l}1 \\
1\end{array}$ & $\begin{array}{c}33 \\
2\end{array}$ \\
\hline $\begin{array}{l}\text { Category 4-2 } \\
\text { present? }\end{array}$ & $\begin{array}{r}\text { No } \\
\text { Yes }\end{array}$ & 1 & 1 & 6 & 2 & 5 & 2 & 15 & 1 & $\begin{array}{l}1 \\
1\end{array}$ & $\begin{array}{c}34 \\
1\end{array}$ \\
\hline $\begin{array}{l}\text { Category 4-3 } \\
\text { present? }\end{array}$ & $\begin{array}{r}\text { No } \\
\text { Yes }\end{array}$ & 1 & 1 & 6 & 2 & 5 & 2 & 15 & 1 & 2 & $\begin{array}{c}35 \\
0\end{array}$ \\
\hline $\begin{array}{l}\text { Category 5-1 } \\
\text { present? }\end{array}$ & $\begin{array}{r}\text { No } \\
\text { Yes }\end{array}$ & 1 & 1 & 6 & 2 & $\begin{array}{l}3 \\
2\end{array}$ & 2 & $\begin{array}{l}8 \\
7\end{array}$ & 1 & $\begin{array}{l}1 \\
1\end{array}$ & $\begin{array}{l}25 \\
10\end{array}$ \\
\hline $\begin{array}{l}\text { Category 5-2 } \\
\text { present? }\end{array}$ & $\begin{array}{r}\text { No } \\
\text { Yes }\end{array}$ & 1 & 1 & 6 & 2 & 5 & 2 & $\begin{array}{c}14 \\
1\end{array}$ & 1 & 2 & $\begin{array}{c}34 \\
1\end{array}$ \\
\hline
\end{tabular}


Category 5-3

present?

Category 5-4

present?

Category 6-1

present?

Category 6-2

present?

Category 6-3

present?

Category 6-4

present?

Category 7-1

present?

Category 7-2

present?

Category 7-3

present?

Category 7-4 present?

Total in Occ. Class

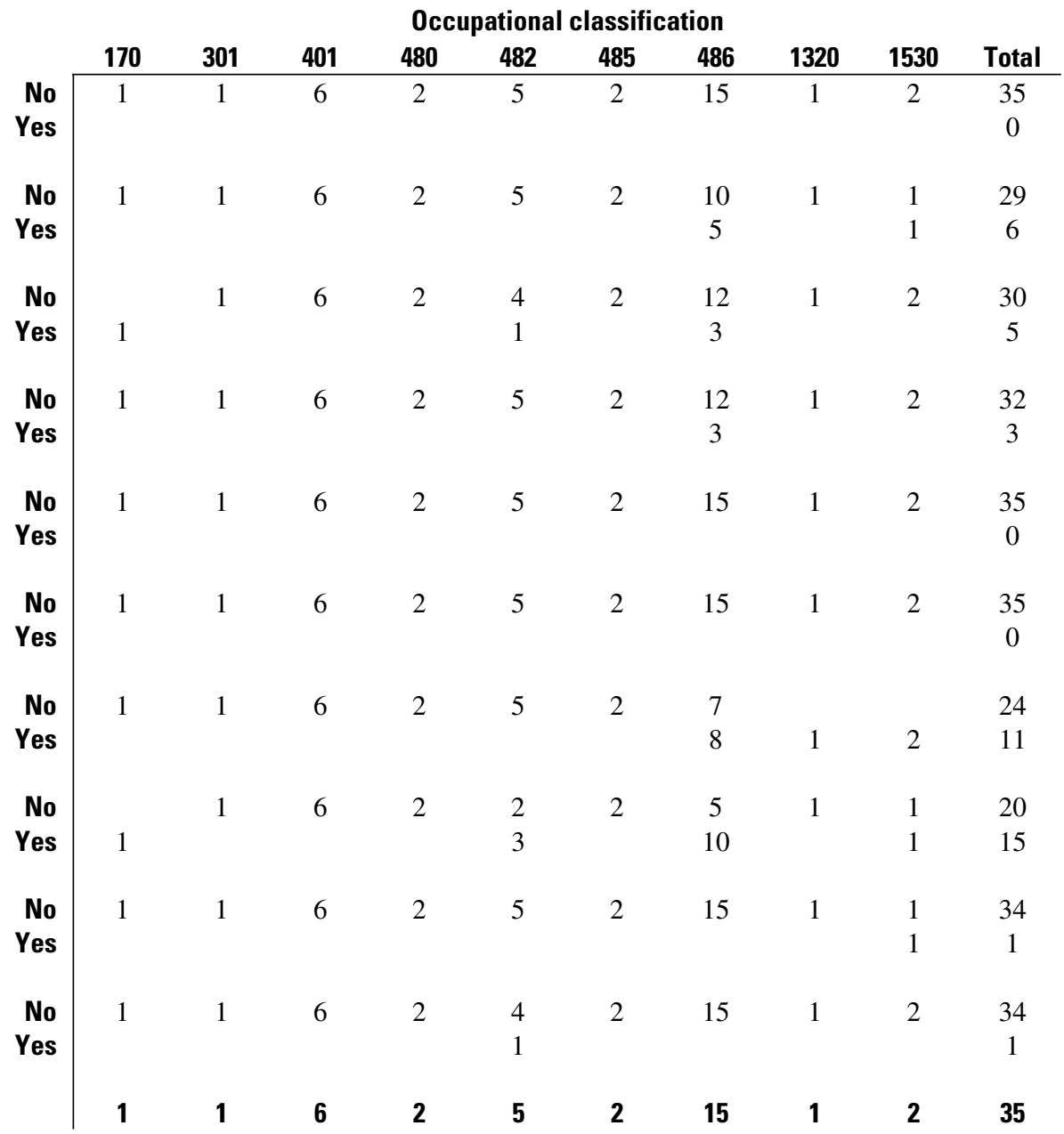




\section{Frequencies}

Number of position descriptions coded $=35$

\begin{tabular}{lcc}
\hline Coding category & Present in PD & Not present in PD \\
\hline (1-1) Research planning - Develop question & & $35(100)^{\mathrm{a}}$ \\
(1-2) Research planning - Design study & $6(17)^{\mathrm{a}}$ & $29(83)$ \\
(1-3) Research planning - Write proposal & & $35(100)$ \\
(1-4) Research planning - Develop research program & $2(6)$ & $33(94)$ \\
(2-1) Research execution - Collect data & $7(20)$ & $28(80)$ \\
(2-2) Research execution - Database management & $1(3)$ & $34(97)$ \\
(2-3) Research execution - Conduct surveys & $1(3)$ & $34(97)$ \\
(2-4) Research execution - Conduct studies/experiments & & $35(100)$ \\
(2-5) Research execution - Conduct inventories & $7(20)$ & $28(80)$ \\
(2-6) Research execution - Conduct monitoring & $5(14)$ & $30(86)$ \\
(2-7) Research execution - Conduct literature review & $1(3)$ & $34(97)$ \\
(3-1) Research analyses - Analyze data & $6(17)$ & $29(83)$ \\
(4-1) Research dissemination - Write reports & $2(6)$ & $33(94)$ \\
(4-2) Research dissemination - Publication & $1(3)$ & $34(97)$ \\
(4-3) Research dissemination - Presentation & & $35(100)$ \\
(5-1) Research application - Management actions & $10(29)$ & $25(71)$ \\
(5-2) Research application - Policy makers & $1(3)$ & $34(97)$ \\
(5-3) Research application - Decision documents & & $35(100)$ \\
(5-4) Research application - New techniques & $6(17)$ & $29(83)$ \\
(6-1) Research collaboration - Non-FWS & $5(14)$ & $30(86)$ \\
(6-2) Research collaboration - Supervision & $3(9)$ & $32(91)$ \\
(6-3) Research collaboration - Identify funding & & $35(100)$ \\
(6-4) Research collaboration - Write funding proposal & $11(31)$ & $35(100)$ \\
(7-1) Knowledge/skill/ability required - Data analysis & $15(43)$ & $24(69)$ \\
(7-2) Knowledge/skill/ability required - Research methods & $1(3)$ & $20(57)$ \\
(7-3) Knowledge/skill/ability required - Statistical software & $1(3)$ & $34(97)$ \\
(7-4) Knowledge/skill/ability required - Document preparation & & $34(97)$ \\
\hline
\end{tabular}

${ }^{\mathrm{a}}$ Percentages in parentheses. 


\section{Appendix 3B. Manifest Content Analysis Results}

Question 1: Is there a relationship between the presence (or absence) of each keyword in a PD and publication status? Answer:

\begin{tabular}{|c|c|c|c|c|c|c|c|c|}
\hline Keyword: & $\begin{array}{l}\text { All FWS } \\
\begin{array}{l}\text { Npub }=408 \\
\text { Nnon }=353\end{array}\end{array}$ & $\begin{array}{l}\text { Region } 1 \\
\text { only } \\
\text { Npub }=112 \\
\text { Nnon }=105\end{array}$ & $\begin{array}{l}\text { Region } 2 \\
\text { only } \\
\text { Npub }=34 \\
\text { Nnon }=34\end{array}$ & $\begin{array}{l}\text { Region } 3 \\
\text { only } \\
\text { Npub }=35 \\
\text { Nnon }=26\end{array}$ & $\begin{array}{l}\text { Region } \mathbf{5} \\
\text { only } \\
\text { Npub }=50 \\
\text { Nnon }=45\end{array}$ & $\begin{array}{l}\text { Region } 6 \\
\text { only } \\
\text { Npub }=67 \\
\text { Nnon }=55\end{array}$ & $\begin{array}{l}\text { Region } 7 \\
\text { only } \\
\text { Npub }=60 \\
\text { Nnon }=45\end{array}$ & $\begin{array}{l}\text { Region } \mathbf{9} \\
\text { only } \\
\text { Npub }=50 \\
\text { Nnon }=43\end{array}$ \\
\hline Analysis & $\begin{array}{l}\text { Yes } \\
\chi^{2}=6.69 \\
\Phi=.09 \\
\varphi^{2}=.01\end{array}$ & No & No & No & No & No & No & No \\
\hline Evaluating & No & No & No & No & No & No & No & No \\
\hline Evaluation & No & No & No & $\begin{array}{l}\text { Yes } \\
\chi^{2}=6.15 \\
\varphi=.32 \\
\varphi^{2}=.10\end{array}$ & No & No & No & No \\
\hline Methods & No & No & No & No & No & No & No & No \\
\hline Monitoring & $\begin{array}{l}\text { Yes } \\
\chi^{2}=4.32 \\
\varphi=.08 \\
\varphi^{2}=.01\end{array}$ & No & No & No & No & No & No & No \\
\hline $\begin{array}{r}\text { National } \\
\text { (excluding } \\
\text { proper names) }\end{array}$ & No & No & No & No & No & No & No & No \\
\hline Problems & No & No & No & No & No & No & No & No \\
\hline Research & $\begin{array}{l}\text { Yes } \\
\chi^{2}=9.97 \\
\varphi=.11 \\
\varphi^{2}=.01\end{array}$ & No & No & $\begin{array}{l}\text { Yes } \\
\chi^{2}=3.99 \\
\varphi=.26 \\
\varphi^{2}=.07\end{array}$ & No & $\begin{array}{l}\text { Yes } \\
\chi^{2}=7.33 \\
\varphi=.25 \\
\varphi^{2}=.06\end{array}$ & No & No \\
\hline Scientific & $\begin{array}{l}\text { Yes } \\
\chi^{2}=4.68 \\
\varphi=.08 \\
\varphi^{2}=.01\end{array}$ & No & No & No & No & No & No & No \\
\hline Studies & No & No & No & $\begin{array}{l}\text { Yes } \\
\chi^{2}=4.21 \\
\varphi=.26 \\
\varphi^{2}=.07\end{array}$ & No & No & No & No \\
\hline
\end{tabular}

Notes. $\chi^{2}=$ Chi Square measure of association. $\varphi=$ Phi, a correlation between two dichotomous variables. $\varphi^{2}=$ an index of the strength of the relationship between two dichotomous variables, can be interpreted as \% of variance. All reported statistics are significant at $p<.05$; values have been rounded to two decimal places. 
Question 2: Is there a relationship between the sum of each keyword appearing at least once in a PD (total number of different keywords appearing in a PD, range $=0-10$ ) and publication status?

\begin{tabular}{|c|c|c|c|c|c|c|c|c|}
\hline & $\begin{array}{l}\text { All FWS } \\
\begin{array}{l}\text { Npub }=408 \\
\text { Nnon }=353\end{array}\end{array}$ & $\begin{array}{l}\text { Region } 1 \\
\text { only } \\
\text { Npub }=112 \\
\text { Nnon }=105\end{array}$ & $\begin{array}{l}\text { Region } 2 \\
\text { only } \\
\text { Npub }=34 \\
\text { Nnon }=34\end{array}$ & $\begin{array}{l}\text { Region } 3 \\
\text { only } \\
\text { Npub }=35 \\
\text { Nnon }=26\end{array}$ & $\begin{array}{l}\text { Region } 5 \\
\text { only } \\
\text { Npub }=50 \\
\text { Nnon }=45\end{array}$ & $\begin{array}{l}\text { Region } 6 \\
\text { only } \\
\text { Npub }=67 \\
\text { Nnon }=55\end{array}$ & $\begin{array}{l}\text { Region } 7 \\
\text { only } \\
\text { Npub }=60 \\
\text { Nnon }=45\end{array}$ & $\begin{array}{l}\text { Region } 9 \\
\text { only } \\
\text { Npub }=50 \\
\text { Nnon }=43\end{array}$ \\
\hline Answer: & $\begin{array}{l}\text { Yes } \\
\mathrm{t}=2.65^{\mathrm{a}}\end{array}$ & No & No & $\begin{array}{l}\text { Yes } \\
\mathrm{t}=3.23^{\mathrm{b}}\end{array}$ & No & No & No & No \\
\hline $\begin{array}{r}\text { Mean- } \\
\text { pub }\end{array}$ & 7.06 & & & 7.11 & & & & \\
\hline $\begin{array}{r}\text { Mean- } \\
\text { non }\end{array}$ & 6.70 & & & 5.92 & & & & \\
\hline
\end{tabular}

Notes. $\mathrm{t}=\mathrm{t}$-test. All reported statistics are significant at $p<.05$ values have been rounded to two decimal places.

${ }^{\mathrm{a}}$ The $95 \%$ confidence interval for the sum of the keywords in PDs of published individuals ranges from 6.88 to 7.23 ; the $95 \%$ confidence interval for non-published individuals ranges from 6.50 to 6.90 . There is a small amount of overlap between the two confidence intervals.

b The 95\% confidence interval for the sum of the keywords in PDs of R3 published individual's ranges from 6.67 to 7.55 ; the $95 \%$ confidence interval for non-published individuals ranges from 5.28 to 6.56 . There is no overlap between the two confidence intervals indicating that these two groups differ. 
Question 3: Is there a relationship between the frequency of each keyword in a PD and publication status? Answer:

\begin{tabular}{|c|c|c|c|c|c|c|c|c|}
\hline Keyword: & $\begin{array}{l}\text { All FWS } \\
\begin{array}{l}\text { Npub }=408 \\
\text { Nnon }=353\end{array}\end{array}$ & $\begin{array}{l}\begin{array}{l}\text { Region } 1 \\
\text { only } \\
\text { Npub }=112 \\
\text { Nnon }=105\end{array} \\
\end{array}$ & $\begin{array}{l}\begin{array}{l}\text { Region } 2 \\
\text { only } \\
\text { Npub }=34 \\
\text { Nnon }=34\end{array} \\
\end{array}$ & $\begin{array}{l}\text { Region } 3 \\
\text { only } \\
\text { Npub }=35 \\
\text { Nnon }=26 \\
\end{array}$ & $\begin{array}{l}\text { Region } 5 \\
\text { only } \\
\text { Npub }=50 \\
\text { Nnon }=45 \\
\end{array}$ & $\begin{array}{l}\text { Region } 6 \\
\text { only } \\
\text { Npub }=67 \\
\text { Nnon }=55 \\
\end{array}$ & $\begin{array}{l}\text { Region } 7 \\
\text { only } \\
\text { Npub }=60 \\
\text { Nnon }=45\end{array}$ & $\begin{array}{l}\text { Region } 9 \\
\text { only } \\
\text { Npub }=50 \\
\text { Nnon }=43\end{array}$ \\
\hline Analysis & $\begin{array}{l}\text { Yes } \\
\mathrm{t}=11.77^{\mathrm{a}}\end{array}$ & No & No & No & $\begin{array}{l}\text { Yes } \\
\mathrm{t}=5.44^{\mathrm{b}}\end{array}$ & No & $\begin{array}{l}\text { Yes } \\
\mathrm{F}=5.58^{\mathrm{b}}\end{array}$ & No \\
\hline Evaluating & No & No & No & No & No & No & No & No \\
\hline Evaluation & No & No & No & $\begin{array}{l}\text { Yes } \\
\mathrm{F}=4.00^{\mathrm{b}}\end{array}$ & No & No & No & No \\
\hline Methods & No & No & No & No & No & No & No & No \\
\hline Monitoring & $\begin{array}{l}\text { Yes } \\
\mathrm{t}=3.99^{\mathrm{b}}\end{array}$ & No & No & No & No & No & No & No \\
\hline $\begin{array}{r}\text { National } \\
\text { (excluding } \\
\text { proper names) }\end{array}$ & No & No & No & No & $\begin{array}{l}\text { Yes } \\
\mathrm{t}=5.41^{\mathrm{b}}\end{array}$ & No & No & No \\
\hline Problems & No & No & No & No & No & No & No & No \\
\hline Research & $\begin{array}{l}\text { Yes } \\
\mathrm{t}=22.74^{\mathrm{c}}\end{array}$ & $\begin{array}{l}\text { Yes } \\
\mathrm{t}=5.21^{\mathrm{b}}\end{array}$ & No & No & No & $\begin{array}{l}\text { Yes } \\
\mathrm{t}=12.08^{\mathrm{e}}\end{array}$ & No & No \\
\hline Scientific & $\begin{array}{l}\text { Yes } \\
t=11.70^{d}\end{array}$ & No & No & No & No & $\begin{array}{l}\text { Yes } \\
\mathrm{t}=5.57^{\mathrm{b}}\end{array}$ & $\begin{array}{l}\text { Yes } \\
F=4.37^{b}\end{array}$ & No \\
\hline Studies & $\begin{array}{l}\text { Yes } \\
\mathrm{t}=7.19^{\mathrm{b}}\end{array}$ & No & No & No & No & No & No & No \\
\hline
\end{tabular}

Notes. $\mathrm{t}=$ Welch's $\mathrm{t}-$ test for unequal variances. All reported statistics are significant at $p<.05$; values have been rounded to two decimal places.

"The 95\% confidence interval for the frequency of "analysis" in the PDs of known publishers ranges from 1.64 to 2.02 ; the $95 \%$ confidence interval for the non-publishers ranges from 1.23 to 1.55 . There is no overlap in these two confidence intervals indicating that the average frequency with which "analysis" appears in the PDs of the two groups is different.

${ }^{\mathrm{b}}$ There is overlap in the $95 \%$ confidence intervals for the frequency of this keyword in the PDs of published and non-published individuals. The two groups may not differ on this variable.

'The 95\% confidence interval for the frequency of "research" in the PDs of known publishers ranges from 2.78 to 3.58 ; the $95 \%$ confidence interval for the non-publishers ranges from 1.69 to 2.27. There is no overlap in these two confidence intervals indicating that the average frequency with which "research" appears in the PDs of the two groups is different.

d The 95\% confidence interval for the frequency of "scientific" in the PDs of known publishers ranges from 2.45 to 3.11 ; the $95 \%$ confidence interval for the non-publishers ranges from 1.80 to 2.31 . There is no overlap in these two confidence intervals indicating that the average frequency with which "scientific" appears in the PDs of the two groups is different.

"The 95\% confidence interval for the frequency of "research" in the PDs of R6 known publishers ranges from 3.73 to 6.33 ; the $95 \%$ confidence interval for the non-publishers ranges from 1.48 to 3.18. There is no overlap in these two confidence intervals indicating that the average frequency with which "research" appears in the PDs of the two groups is different. 
Question 4: Is there a relationship between the sum of the frequencies of all keywords in a PD (all keyword frequencies summed together) and publication status?

\begin{tabular}{|c|c|c|c|c|c|c|c|c|}
\hline & $\begin{array}{l}\text { All FWS } \\
\begin{array}{l}\text { Npub }=408 \\
\text { Nnon }=353\end{array}\end{array}$ & $\begin{array}{l}\text { Region } 1 \\
\text { only } \\
\text { Npub }=112 \\
\text { Nnon }=105\end{array}$ & $\begin{array}{l}\begin{array}{l}\text { Region } 2 \\
\text { only } \\
\text { Npub }=34 \\
\text { Nnon }=34\end{array} \\
\end{array}$ & $\begin{array}{l}\text { Region } 3 \\
\text { only } \\
\text { Npub }=35 \\
\text { Nnon }=26\end{array}$ & $\begin{array}{l}\begin{array}{l}\text { Region } 5 \\
\text { only }\end{array} \\
\text { Npub }=50 \\
\text { Nnon }=45\end{array}$ & $\begin{array}{l}\text { Region } 6 \\
\text { only } \\
\text { Npub }=67 \\
\text { Nnon }=55\end{array}$ & $\begin{array}{l}\text { Region } 7 \\
\text { only } \\
\text { Npub = } 60 \\
\text { Nnon }=45 \\
\end{array}$ & $\begin{array}{l}\text { Region } 9 \\
\text { only } \\
\text { Npub }=50 \\
\text { Nnon }=43\end{array}$ \\
\hline Answer: & $\begin{array}{l}\text { Yes } \\
\mathrm{t}=14.51^{\mathrm{a}}\end{array}$ & No & No & No & $\begin{array}{l}\text { Yes } \\
\mathrm{F}=4.80^{\mathrm{b}}\end{array}$ & $\begin{array}{l}\text { Yes } \\
\mathrm{F}=4.45^{\mathrm{b}}\end{array}$ & No & No \\
\hline Means: & $\begin{array}{l}\text { Mpub = } \\
25.03 \\
\text { Mnon }= \\
21.45\end{array}$ & $\begin{array}{l}\text { Mpub = } \\
22.98 \\
\text { Mnon = } \\
20.59\end{array}$ & $\begin{array}{l}\text { Mpub = } \\
27.15 \\
\text { Mnon = } \\
23.68\end{array}$ & $\begin{array}{l}\text { Mpub = } \\
22.69 \\
\text { Mnon = } \\
19.88\end{array}$ & $\begin{array}{l}\text { Mpu b= } \\
25.5 \\
\text { Mnon = } \\
19.87\end{array}$ & $\begin{array}{l}\text { Mpub = } \\
29.43 \\
\text { Mnon = } \\
23.35\end{array}$ & $\begin{array}{l}\text { Mpub = } \\
31.08 \\
\text { Mnon = } \\
27.07\end{array}$ & $\begin{array}{l}\text { Mpub = } \\
16.18 \\
\text { Mnon = } \\
16.12\end{array}$ \\
\hline Ranges: & $\begin{array}{l}\text { All } \\
(1-128) \\
\text { Pub } \\
(1-128) \\
\text { Non } \\
(1-69)\end{array}$ & $\begin{array}{l}\text { All } \\
(4-78) \\
\text { Pub } \\
(5-78) \\
\text { Non } \\
(4-49)\end{array}$ & $\begin{array}{l}\text { All } \\
(9-98) \\
\text { Pub } \\
(12-98) \\
\text { Non } \\
(9-69)\end{array}$ & $\begin{array}{l}\text { All } \\
(7-43) \\
\text { Pub } \\
(7-43) \\
\text { Non } \\
(7-37)\end{array}$ & $\begin{array}{l}\text { All } \\
(5-62) \\
\text { Pub } \\
(6-62) \\
\text { Non } \\
(5-55)\end{array}$ & $\begin{array}{l}\text { All } \\
(3-128) \\
\text { Pub } \\
(4-128) \\
\text { Non } \\
(3-63)\end{array}$ & $\begin{array}{l}\text { All } \\
(4-63) \\
\text { Pub } \\
(6-58) \\
\text { Non } \\
(4-63)\end{array}$ & $\begin{array}{l}\text { All } \\
(1-32) \\
\text { Pub } \\
(1-32) \\
\text { Non } \\
(1-30)\end{array}$ \\
\hline
\end{tabular}

Notes. All reported statistics are significant at $p<.05$, values have been rounded to two decimal places.

\footnotetext{
${ }^{\mathrm{a}}$ The $95 \%$ confidence interval for the frequency of keywords in the PDs of known publishers ranges from 23.61 to 26.45 ; the $95 \%$ confidence interval for the non-publishers ranges from 20.29 to 22.61 . There is no overlap in these two confidence intervals indicating that the average frequency with which keywords appear in the PDs of the two groups is different.

${ }^{b}$ There is overlap in the $95 \%$ confidence intervals for the frequency of keywords in the PDs of published and non-published individuals. The two groups may not differ on this variable.
} 


\section{Appendix 3C. Latent Content Analysis Results}

\begin{tabular}{|c|c|c|c|c|}
\hline Category & \multicolumn{2}{|c|}{ Sub category } & Definition & \multirow{2}{*}{$\begin{array}{l}\text { question to be } \\
\text { cific project. }\end{array}$} \\
\hline (1) Research planning & $\begin{array}{l}\text { (1) I } \\
\text { form }\end{array}$ & $\begin{array}{l}\text { lop research question/ } \\
\text { te hypotheses* }\end{array}$ & $\begin{array}{l}\text { Creating a spec } \\
\text { addressed by a }\end{array}$ & \\
\hline Region & $\begin{array}{l}\text { PDs coded with this } \\
\text { sub category }\end{array}$ & $\begin{array}{l}\text { Relationship with } \\
\text { publication status }\end{array}$ & $\begin{array}{l}\text { Relationship with GS } \\
\text { level (limited range) }\end{array}$ & $\begin{array}{l}\text { Relationship with } \\
\text { occupational } \\
\text { classification } \\
\text { (limited range) }\end{array}$ \\
\hline All FWS & 4 of $244(2 \%)$ & - & - & - \\
\hline 1 & 0 of $43(0 \%)$ & - & - & - \\
\hline 2 & 0 of $31(0 \%)$ & - & - & - \\
\hline 3 & 0 of $29(0 \%)$ & - & - & - \\
\hline 5 & 1 of $32(3 \%)$ & No & - & - \\
\hline 6 & 2 of $38(5 \%)$ & No & - & - \\
\hline 7 & 1 of $36(3 \%)$ & No & - & - \\
\hline 9 & 0 of $35(0 \%)$ & - & - & - \\
\hline
\end{tabular}

Notes. - indicates that the data were too sparse to permit testing of a relationship between the variables.

\begin{tabular}{|c|c|c|c|c|}
\hline Category & \multicolumn{2}{|c|}{ Sub category } & Definition & \\
\hline (1) Research planning & \multicolumn{2}{|c|}{$\begin{array}{l}\text { (2) Design research study/data } \\
\text { collection method* }\end{array}$} & \multicolumn{2}{|c|}{$\begin{array}{l}\text { Designing the format of a study or the } \\
\text { process by which a study will be } \\
\text { conducted. }\end{array}$} \\
\hline Region & $\begin{array}{l}\text { PDs coded with this } \\
\text { sub category }\end{array}$ & $\begin{array}{l}\text { Relationship with } \\
\text { publication status }\end{array}$ & $\begin{array}{l}\text { Relationship with GS } \\
\text { level (limited range) }\end{array}$ & $\begin{array}{l}\text { Relationship with } \\
\text { occupational } \\
\text { classification } \\
\text { (limited range) }\end{array}$ \\
\hline All FWS & 96 of $244(39 \%)$ & Yes & Yes & Yes \\
\hline 1 & 15 of $43(35 \%)$ & No & - & - \\
\hline 2 & 18 of $31(58 \%)$ & No & - & - \\
\hline 3 & 7 of $29(24 \%)$ & No & - & - \\
\hline 5 & 14 of $32(44 \%)$ & No & - & - \\
\hline 6 & 14 of $38(37 \%)$ & No & - & - \\
\hline 7 & 22 of $36(61 \%)$ & Yes & - & - \\
\hline 9 & 6 of $35(17 \%)$ & No & - & - \\
\hline
\end{tabular}

Notes. - indicates that the data were too sparse to permit testing of a relationship between the variables.

All FWS:

Publication status: $\chi^{2}=9.60, p<.05$. Chi-square analysis indicates a statistically significant relationship between this content and publication status. The measure of the strength of the relationship, $p h i=.20, p<.05$, indicating a moderate relationship. Of the 125 individuals in this sample who had published, $61(49 \%)$ had this content in their position description; 35 (29\%) of the 119 non-publishers had this content.

GS level: $\chi^{2}=18.39, p<.05$. Chi-square analysis indicates a statistically significant relationship between this sub category and GS Level. The measure of the strength of the relationship, Cramer's $\mathrm{V}=.29, p<.05$, indicating a moderate relationship. More than half of the individuals in GS level $11(31 / 55=56 \%)$ had content fitting this sub category in their position descriptions.

Occupational classification: $\chi^{2}=30.84, p<.05$. Chi-square analysis indicates a statistically significant relationship between this sub category and occupational classification. The measure of the strength of the relationship, Cramer's $\mathrm{V}=.36, p<.05$, indicating a moderately strong relationship. A substantial proportion (75\% or greater) of the individuals in occupational classifications 193-Archaeology $(1 / 1=100 \%), 408$-Ecology $(1 / 1=100 \%), 430$-Botany 
$(1 / 1=100 \%)$, and $701-$ Veterinary Medical Science $(1 / 1=100 \%)$ had content fitting this sub category in their position descriptions. Of the position descriptions with this content, the largest proportion were classified as 486Wildlife Biology $(35 / 96=36 \%)$.

\section{Region 7:}

Publication status: $\chi^{2}=7.88, p<.05$. Chi-square analysis indicates a statistically significant relationship between this content and publication status. The measure of the strength of the relationship, phi $=.47, p<.05$, indicating a moderately strong relationship. Of the 23 individuals in this sample who had published, 18 (78\%) had this content in their position description; 4 (31\%) of the 13 non-publishers had this content.

\section{Category}

(1) Research planning
Sub category

(3) Write research project proposal*

Definition

\begin{tabular}{rr|cccc}
\multicolumn{1}{r|}{ Region } & PDs coded with this & $\begin{array}{l}\text { Relationship with } \\
\text { publication status }\end{array}$ & $\begin{array}{l}\text { Relationship with GS } \\
\text { level (limited range) }\end{array}$ & $\begin{array}{l}\text { Relationship with } \\
\text { occupational } \\
\text { classification } \\
\text { (limited range) }\end{array}$ \\
\hline All FWS & $\begin{array}{r}12 \text { of } 244(5 \%) \\
\mathbf{1}\end{array}$ & 0 of $43(0 \%)$ & No & - & - \\
$\mathbf{2}$ & 0 of $31(0 \%)$ & - & - & - \\
$\mathbf{3}$ & 0 of $29(0 \%)$ & - & - & - \\
$\mathbf{5}$ & 3 of $32(9 \%)$ & No & - & - \\
$\mathbf{6}$ & 7 of $38(18 \%)$ & No & - & - \\
$\mathbf{7}$ & 2 of $36(6 \%)$ & No & - & -
\end{tabular}

Notes. - indicates that the data were too sparse to permit testing of a relationship between the variables.

\section{Category}

(1) Research planning

\section{Sub category}

(4) Develop research program/set research agenda

\section{Definition}

Identifying information needs, or research projects to be pursued; this may include determining which projects will be funded.

\begin{tabular}{|c|c|c|c|c|}
\hline Region & $\begin{array}{l}\text { PDs coded with this } \\
\text { sub category }\end{array}$ & $\begin{array}{l}\text { Relationship with } \\
\text { publication status }\end{array}$ & $\begin{array}{l}\text { Relationship with GS } \\
\text { level (limited range) }\end{array}$ & $\begin{array}{l}\text { Relationship with } \\
\text { occupational } \\
\text { classification } \\
\text { (limited range) }\end{array}$ \\
\hline All FWS & 49 of $244(20 \%)$ & No & No & No \\
\hline 1 & 7 of $43(16 \%)$ & No & - & - \\
\hline 2 & 10 of $31(32 \%)$ & No & - & - \\
\hline 3 & 1 of $29(3 \%)$ & No & - & - \\
\hline 5 & 15 of $32(47 \%)$ & No & - & - \\
\hline 6 & 7 of $38(18 \%)$ & No & - & - \\
\hline 7 & 7 of $36(19 \%)$ & No & - & - \\
\hline 9 & 2 of $35(6 \%)$ & No & - & - \\
\hline
\end{tabular}

Notes. - indicates that the data were too sparse to permit testing of a relationship between the variables. 


\begin{tabular}{|c|c|c|c|c|}
\hline Region & $\begin{array}{l}\text { PDs coded with this } \\
\text { sub category }\end{array}$ & $\begin{array}{l}\text { Relationship with } \\
\text { publication status }\end{array}$ & $\begin{array}{l}\text { Relationship with GS } \\
\text { level (limited range) }\end{array}$ & $\begin{array}{l}\text { Relationship with } \\
\text { occupational } \\
\text { classification } \\
\text { (limited range) }\end{array}$ \\
\hline All FWS & 93 of $244(38 \%)$ & No & Yes & Yes \\
\hline 1 & 12 of $43(28 \%)$ & No & - & - \\
\hline 2 & 18 of $31(58 \%)$ & No & - & - \\
\hline 3 & 9 of $29(31 \%)$ & No & - & - \\
\hline 5 & 15 of $32(47 \%)$ & No & - & - \\
\hline 6 & 15 of $38(40 \%)$ & No & - & - \\
\hline 7 & 17 of $36(47 \%)$ & No & - & - \\
\hline 9 & 7 of $35(20 \%)$ & No & - & - \\
\hline
\end{tabular}

Notes. - indicates that the data were too sparse to permit testing of a relationship between the variables.

\section{All FWS:}

GS level: $\chi^{2}=23.58, p<.05$. Chi-square analysis indicates a statistically significant relationship between this sub category and GS Level. The measure of the strength of the relationship, Cramer's V $=.32, p<.05$, indicating a moderately strong relationship. Greater than half of the individuals in GS level $11(32 / 55=58 \%)$ had content fitting this sub category in their position descriptions.

Occupational classification: $\chi^{2}=18.81, p<.05$. Chi-square analysis indicates a statistically significant relationship between this sub category and occupational classification. The measure of the strength of the relationship, Cramer's $\mathrm{V}=.29, p<.05$, indicating a moderately strong relationship. None of the occupation classifications analyzed had more than 50\% of PD with this content. Of the position descriptions with this content, the largest proportion of them were classified as 401-General Biological Science $(34 / 86=40 \%)$.

\section{Category}

(2) Research execution
Sub category

(2) Organize and manage data/database
Definition

Compiling data into a database.

\begin{tabular}{|c|c|c|c|c|}
\hline Region & $\begin{array}{l}\text { PDs coded with this } \\
\text { sub category }\end{array}$ & $\begin{array}{l}\text { Relationship with } \\
\text { publication status }\end{array}$ & $\begin{array}{l}\text { Relationship with GS } \\
\text { level (limited range) }\end{array}$ & $\begin{array}{l}\text { Relationship with } \\
\text { occupational } \\
\text { classification } \\
\text { (limited range) }\end{array}$ \\
\hline All FWS & 29 of $244(12 \%)$ & No & No & No \\
\hline 1 & 6 of $43(14 \%)$ & No & - & - \\
\hline 2 & 8 of $31(26 \%)$ & No & - & - \\
\hline 3 & 0 of $29(0 \%)$ & - & - & - \\
\hline 5 & 5 of $32(16 \%)$ & No & - & - \\
\hline 6 & 5 of $38(13 \%)$ & No & - & - \\
\hline 7 & 4 of $36(11 \%)$ & No & - & - \\
\hline 9 & 1 of $35(3 \%)$ & No & - & - \\
\hline
\end{tabular}

Notes. - indicates that the data were too sparse to permit testing of a relationship between the variables. 


\begin{tabular}{rr|cccc}
\multicolumn{1}{r|}{ Region } & PDs coded with this & $\begin{array}{l}\text { Relationship with } \\
\text { publication status }\end{array}$ & $\begin{array}{l}\text { Relationship with } \\
\text { occupational } \\
\text { classification } \\
\text { (limited range) }\end{array}$ \\
\hline All FWS & 2 of $244(1 \%)$ & - & - & - \\
1 & 0 of $43(0 \%)$ & - & - & - \\
2 & 0 of $31(0 \%)$ & No & - & - \\
3 & 1 of $29(3 \%)$ & - & - & - \\
5 & 0 of $32(0 \%)$ & - & - & - \\
6 & 0 of $38(0 \%)$ & - & - & -
\end{tabular}

Notes. - indicates that the data were too sparse to permit testing of a relationship between the variables.

Category

(2) Research execution
Subcategory

(4) Conduct studies/experiments

\section{Definition}

Participating in conducting a research study (i.e., a non-survey study; a study in which some type of intervention is applied).

\begin{tabular}{rr|cccc}
\multicolumn{1}{r|}{ Region } & PDs coded with this & $\begin{array}{l}\text { Relationship with } \\
\text { publication status }\end{array}$ & $\begin{array}{l}\text { Relationship with } \\
\text { occupational } \\
\text { classification } \\
\text { level (limited range) }\end{array}$ & $\begin{array}{l}\text { Relationship with GS } \\
\text { (limited range) }\end{array}$ \\
\hline All FWS & 11 of $244(5 \%)$ & No & - & - \\
1 & 3 of $43(7 \%)$ & No & - & - \\
2 & 7 of $31(23 \%)$ & No & - & - \\
3 & 0 of $29(0 \%)$ & No & - & - \\
5 & 1 of $32(3 \%)$ & - & - & - \\
6 & 0 of $38(0 \%)$ & - & - & -
\end{tabular}

Notes. - indicates that the data were too sparse to permit testing of a relationship between the variables.

Category

(2) Research execution
Subcategory

(5) Conduct inventories/field studies

\section{Definition}

Participating in a count of the current status of a plant or animal.

\begin{tabular}{|c|c|c|c|c|}
\hline Region & $\begin{array}{l}\text { PDs coded with this } \\
\text { sub category }\end{array}$ & $\begin{array}{l}\text { Relationship with } \\
\text { publication status }\end{array}$ & $\begin{array}{l}\text { Relationship with GS } \\
\text { level (limited range) }\end{array}$ & $\begin{array}{l}\text { Relationship with } \\
\text { occupational } \\
\text { classification } \\
\text { (limited range) }\end{array}$ \\
\hline All FWS & 82 of $244(34 \%)$ & No & Yes & Yes \\
\hline 1 & 10 of $43(23 \%)$ & No & - & - \\
\hline 2 & 15 of $31(48 \%)$ & No & - & - \\
\hline 3 & 2 of $29(7 \%)$ & No & - & - \\
\hline 5 & 10 of $32(31 \%)$ & No & - & - \\
\hline 6 & 13 of $38(34 \%)$ & No & - & - \\
\hline 7 & 25 of $36(69 \%)$ & No & - & - \\
\hline 9 & 7 of $35(20 \%)$ & Yes & - & - \\
\hline
\end{tabular}

Notes. - indicates that the data were too sparse to permit testing of a relationship between the variables. 


\section{All FWS:}

GS Level: $\chi^{2}=21.75, p<.05$. Chi-square analysis indicates a statistically significant relationship between this sub category and GS Level. The measure of the strength of the relationship, Cramer's V $=.31, p<.05$, indicating a moderately strong relationship. More than half of the individuals in GS level $11(28 / 55=51 \%)$ had content fitting this sub category in their position descriptions.

Occupational classification: $\chi^{2}=32.79, p<.05$. Chi-square analysis indicates a statistically significant relationship between this sub category and occupational classification. The measure of the strength of the relationship, Cramer's $\mathrm{V}=.37, p<.05$, indicating a moderately strong relationship. None of the occupational classifications analyzed had more than $50 \%$ of PDs with this content. Of the position descriptions with this content, the largest proportion of them were classified as 486-Wildlife Biology $(39 / 80=49 \%)$.

\section{Region 9:}

Publication status: $\chi^{2}=5.64, p<.05$. Chi-square analysis indicates a statistically significant relationship between this content and publication status. The measure of the strength of the relationship, $p h i=.40, p<.05$, indicating a moderately strong relationship. Of the 16 individuals in this sample who had published, $6(38 \%)$ had this content in their position description; 1 (5\%) of the 19 non-publishers had this content.

\begin{tabular}{|c|c|c|c|c|}
\hline Category & Sub & gory & Definition & \\
\hline (2) Research execution & (6) & luct monitoring & $\begin{array}{l}\text { Participating in } \\
\text { performance of } \\
\text { standard; this c } \\
\text { projects addres } \\
\text { characteristic tl } \\
\text { will require cor }\end{array}$ & $\begin{array}{l}\text { neasure of the } \\
\text { me indicator against a } \\
\text { yory may apply to } \\
\text { a specific } \\
\text { more likely than not } \\
\text { rison to a standard. }\end{array}$ \\
\hline Region & $\begin{array}{l}\text { PDs coded with this } \\
\text { sub category }\end{array}$ & $\begin{array}{l}\text { Relationship with } \\
\text { publication status }\end{array}$ & $\begin{array}{l}\text { Relationship with GS } \\
\text { level (limited range) }\end{array}$ & $\begin{array}{l}\text { Relationship with } \\
\text { occupational } \\
\text { classification } \\
\text { (limited range) }\end{array}$ \\
\hline All FWS & 46 of $244(19 \%)$ & No & Yes & Yes \\
\hline 1 & 9 of $43(21 \%)$ & No & - & - \\
\hline 2 & 9 of $31(29 \%)$ & No & - & - \\
\hline 3 & 2 of $29(7 \%)$ & No & - & - \\
\hline 5 & 4 of $32(13 \%)$ & No & - & - \\
\hline 6 & 10 of $38(26 \%)$ & No & - & - \\
\hline 7 & 7 of $36(19 \%)$ & No & - & - \\
\hline 9 & 5 of $35(14 \%)$ & No & - & - \\
\hline
\end{tabular}

Notes. - indicates that the data were too sparse to permit testing of a relationship between the variables.

\section{All FWS:}

GS Level: $\chi^{2}=9.34, p<.05$. Chi-square analysis indicates a statistically significant relationship between this sub category and GS Level. The measure of the strength of the relationship, Cramer's V $=.20, p<.05$, indicating a moderate relationship. There were no GS levels in which more than half of the individuals had content fitting this sub category in their position descriptions.

Occupational classification: $\chi^{2}=21.06, p<.05$. Chi-square analysis indicates a statistically significant relationship between this sub category and occupational classification. The measure of the strength of the relationship, Cramer's $\mathrm{V}=.30, p<.05$, indicating a moderately strong relationship. None of the occupational classifications analyzed had more than $50 \%$ of PDs with this content. Of the position descriptions with this content, the largest proportion of them were classified as 486-Wildlife Biology $(22 / 40=55 \%)$. 


$\begin{array}{lc}\text { Region } & \\ \text { All FWS } & \begin{array}{l}\text { PDs coded with this } \\ \text { sub category }\end{array} \\ \mathbf{1} & 11 \text { of } 244(5 \%) \\ \mathbf{2} & \text { of } 43(2 \%) \\ \mathbf{3} & 0 \text { of } 31(13 \%) \\ \mathbf{5} & 3 \text { of } 32(9 \%) \\ \mathbf{6} & 1 \text { of } 38(3 \%) \\ \mathbf{7} & 1 \text { of } 36(3 \%) \\ \mathbf{9} & 1 \text { of } 35(3 \%)\end{array}$

Relationship with
publication status
No
No
No
-
No
No
No
No

Relationship with occupational classification Relationship with GS level (limited range) (limited range)

Notes. - indicates that the data were too sparse to permit testing of a relationship between the variables.

Category

(3) Research analyses
Subcategory

(1) Analyze data*

Definition

Analyzing data using qualitative or quantitative methods.

\begin{tabular}{rr|rccc}
\multicolumn{1}{r|}{ Region } & PDs coded with this & Relationship with & & \multicolumn{1}{c}{$\begin{array}{l}\text { Relationship with } \\
\text { occupational } \\
\text { classification } \\
\text { (limited range) }\end{array}$} \\
\hline All FWS & 95 of $244(39 \%)$ & $\begin{array}{l}\text { Relationship with GS } \\
\text { level (limited range) }\end{array}$ & Yes & Yes \\
$\mathbf{1}$ & 12 of $43(28 \%)$ & No & - & - \\
$\mathbf{2}$ & 18 of $31(58 \%)$ & No & - & - \\
$\mathbf{3}$ & 10 of $29(35 \%)$ & Yes & - & - \\
$\mathbf{5}$ & 16 of $32(50 \%)$ & Yes & - & - \\
$\mathbf{6}$ & 13 of $38(34 \%)$ & No & - & -
\end{tabular}

Notes. - indicates that the data were too sparse to permit testing of a relationship between the variables.

\section{All FWS:}

Publication status: $\chi^{2}=8.86, p<.05$. Chi-square analysis indicates a statistically significant relationship between this content and publication status. The measure of the strength of the relationship, phi $=.19, p<.05$, indicating a moderate relationship. Of the 125 individuals in this sample who had published, $60(48 \%)$ had this content in their position description; 35 (29\%) of the 119 non-publishers had this content.

GS level: $\chi^{2}=15.96, p<.05$. Chi-square analysis indicates a statistically significant relationship between this sub category and GS Level. The measure of the strength of the relationship, Cramer's $\mathrm{V}=.27, p<.05$, indicating a moderately strong relationship. Half of the individuals in GS level $12(39 / 78=50 \%)$ had content fitting this sub category in their position descriptions.

Occupational classification: $\chi^{2}=19.10, p<.05$. Chi-square analysis indicates a statistically significant relationship between this sub category and occupational classification. The measure of the strength of the relationship, Cramer's $\mathrm{V}=.29, p<.05$, indicating a moderately strong relationship. None of the occupational classifications analyzed had more than $50 \%$ of PDs with this content. Of the position descriptions with this content, the largest proportion of them were classified as 486-Wildlife Biology $(33 / 90=37 \%)$.

\section{Region 3:}

Publication status: $\chi^{2}=6.20, p<.05$. Chi-square analysis indicates a statistically significant relationship between this content and publication status. The measure of the strength of the relationship, $p h i=.46, p<.05$, indicating a moderately strong relationship. Of the 17 individuals in this sample who had published, $9(53 \%)$ had this content in their position description; $1(8 \%)$ of the 12 non-publishers had this content. 


\title{
Region 5:
}

Publication status: $\chi^{2}=4.80, p<.05$. Chi-square analysis indicates a statistically significant relationship between this content and publication status. The measure of the strength of the relationship, $p h i=.39, p<.05$, indicating a moderately strong relationship. Of the 12 individuals in this sample who had published, $9(75 \%)$ had this content in their position description; 7 (35\%) of the 20 non-publishers had this content.

\section{Category}

(4) Research dissemination

\section{Sub category}

(1) Write reports from data*

\section{Definition}

Writing up results of a data set into a report.

\begin{tabular}{|c|c|c|c|c|}
\hline Region & $\begin{array}{l}\text { PDs coded with this } \\
\text { sub category }\end{array}$ & $\begin{array}{l}\text { Relationship with } \\
\text { publication status }\end{array}$ & $\begin{array}{l}\text { Relationship with GS } \\
\text { level (limited range) }\end{array}$ & $\begin{array}{l}\text { Relationship with } \\
\text { occupational } \\
\text { classification } \\
\text { (limited range) }\end{array}$ \\
\hline All FWS & 57 of $244(23 \%)$ & Yes & Yes & Yes \\
\hline 1 & 8 of $43(19 \%)$ & No & - & - \\
\hline 2 & 7 of $31(23 \%)$ & No & - & - \\
\hline 3 & 3 of $29(10 \%)$ & No & - & - \\
\hline 5 & 11 of $32(34 \%)$ & No & - & - \\
\hline 6 & 10 of $38(26 \%)$ & No & - & - \\
\hline 7 & 16 of $36(44 \%)$ & No & - & - \\
\hline 9 & 2 of $35(6 \%)$ & No & - & - \\
\hline
\end{tabular}

Notes. - indicates that the data were too sparse to permit testing of a relationship between the variables.

\begin{abstract}
All FWS:
Publication status: $\chi^{2}=5.57, p<.05$. Chi-square analysis indicates a statistically significant relationship between this content and publication status. The measure of the strength of the relationship, $p h i=.15, p<.05$, indicating a weak relationship. Of the 125 individuals in this sample who had published, $37(30 \%)$ had this content in their position description; 20 (17\%) of the 119 non-publishers had this content.
\end{abstract}

GS level: $\chi^{2}=17.63, p<.05$. Chi-square analysis indicates a statistically significant relationship between this sub category and GS Level. The measure of the strength of the relationship, Cramer's V $=.28, p<.05$, indicating a moderately strong relationship. No GS level had a proportion greater than $50 \%$ of position descriptions with this content. Of the position descriptions that did have this content, the largest proportion $(27 / 54=50 \%)$ were GS-12.

Occupational classification: $\chi^{2}=13.84, p<.05$. Chi-square analysis indicates a statistically significant relationship between this sub category and occupational classification. The measure of the strength of the relationship, Cramer's $\mathrm{V}=.24, p<.05$, indicating a moderate relationship. None of the occupational classifications analyzed had more than $50 \%$ of PDs with this content. Of the position descriptions with this content, the largest proportion of them were classified as 401-General Biological Science $(22 / 54=41 \%)$. 
Category

(4) Research dissemination
Sub category

(2) Write articles for publication from research data.

\section{Definition}

Writing research based articles for publication in (professional or scientific) journals.

\begin{tabular}{rr|rccc}
\multicolumn{1}{r|}{ Region } & PDs coded with this & Relationship with & & \multicolumn{1}{c}{$\begin{array}{l}\text { Relationship with } \\
\text { occupational } \\
\text { classification } \\
\text { (limited range) }\end{array}$} \\
\hline All FWS & 28 of $244(12 \%)$ & No & $\begin{array}{l}\text { Relationship with GS } \\
\text { level (limited range) }\end{array}$ & Yes & Yes \\
$\mathbf{1}$ & 4 of $43(9 \%)$ & No & - & - \\
$\mathbf{2}$ & 4 of $31(13 \%)$ & No & No & - & - \\
$\mathbf{3}$ & 3 of $29(10 \%)$ & - & - & - \\
$\mathbf{5}$ & 0 of $32(0 \%)$ & No & - & - \\
$\mathbf{6}$ & 5 of $38(13 \%)$ & No & - & -
\end{tabular}

Notes. - indicates that the data were too sparse to permit testing of a relationship between the variables.

\section{All FWS:}

GS level: $\chi^{2}=9.76, p<.05$. Chi-square analysis indicates a statistically significant relationship between this sub category and GS Level. The measure of the strength of the relationship, Cramer's $\mathrm{V}=.21, p<.05$, indicating a moderate relationship. No GS level had a proportion greater than $50 \%$ of position descriptions with this content. Of the position descriptions that did have this content, the largest proportion $(15 / 27=56 \%)$ were GS-12.

Occupational classification: $\chi^{2}=22.84, p<.05$. Chi-square analysis indicates a statistically significant relationship between this sub category and occupational classification. The measure of the strength of the relationship, Cramer's $\mathrm{V}=.31, p<.05$, indicating a strong relationship. None of the occupational classifications analyzed had more than $50 \%$ of PDs with this content. Of the position descriptions with this content, the largest proportion of them were classified as 486-Wildlife Biology $(15 / 23=65 \%)$.

\begin{tabular}{lll} 
Category & Sub category & Definition \\
\hline (4) Research dissemination & (3) Present research in professional & Presenting research in professional \\
& forums (conferences, meetings, & forums (conferences, meetings, \\
symposia, etc.) & symposia, etc.)
\end{tabular}

\begin{tabular}{rr|rccc}
\multicolumn{1}{r|}{ Region } & PDs coded with this & Relationship with \\
sub category & publication status & $\begin{array}{l}\text { Relationship with } \\
\text { Reccupational } \\
\text { level (limited range) }\end{array}$ & $\begin{array}{l}\text { classification } \\
\text { (limited range) }\end{array}$ \\
\hline All FWS & 21 of $244(9 \%)$ & No & No & - \\
$\mathbf{1}$ & 4 of $43(9 \%)$ & No & - & - \\
$\mathbf{2}$ & 5 of $31(16 \%)$ & Yes & - & - \\
$\mathbf{3}$ & 1 of $29(3 \%)$ & No & - & - \\
$\mathbf{5}$ & 1 of $32(3 \%)$ & No & - & - \\
$\mathbf{6}$ & 5 of $38(13 \%)$ & No & - & -
\end{tabular}

Notes. - indicates that the data were too sparse to permit testing of a relationship between the variables.

\section{Region 2:}

Publication status: $\chi^{2}=5.59, p<.05$. Chi-square analysis indicates a statistically significant relationship between this content and publication status. The measure of the strength of the relationship, $p h i=-.43, p<.05$, indicating a moderately strong relationship in a negative direction. Of the 15 individuals in this sample who had published, none had this content in their position description; 5 (31\%) of the 16 non-publishers had this content. 
Category

(5) Research application

Note: Research application can be used in situations in which a person did not personally collect the data or is otherwise not using original data.

\section{Sub category}

(1) Use research-based information to evaluate or inform management actions*

\section{Definition}

Use research-based information to evaluate or inform management actions.

\begin{tabular}{|c|c|c|c|c|}
\hline Region & $\begin{array}{l}\text { PDs coded with this } \\
\text { sub category }\end{array}$ & $\begin{array}{l}\text { Relationship with } \\
\text { publication status }\end{array}$ & $\begin{array}{l}\text { Relationship with GS } \\
\text { level (limited range) }\end{array}$ & $\begin{array}{l}\text { Relationship with } \\
\text { occupational } \\
\text { classification } \\
\text { (limited range) }\end{array}$ \\
\hline All FWS & 103 of $244(42 \%)$ & Yes & No & No \\
\hline 1 & 16 of $43(37 \%)$ & No & - & - \\
\hline 2 & 19 of $31(61 \%)$ & Yes & - & - \\
\hline 3 & 14 of $29(48 \%)$ & No & - & - \\
\hline 5 & 10 of $32(31 \%)$ & No & - & - \\
\hline 6 & 14 of $38(37 \%)$ & No & - & - \\
\hline 7 & 20 of $36(56 \%)$ & No & - & - \\
\hline 9 & 10 of $35(29 \%)$ & Yes & - & - \\
\hline
\end{tabular}

Notes. - indicates that the data were too sparse to permit testing of a relationship between the variables.

\section{All FWS:}

Publication status: $\chi^{2}=7.04, p<.05$. Chi-square analysis indicates a statistically significant relationship between this content and publication status. The measure of the strength of the relationship, $p h i=.17, p<.05$, indicating a weak relationship. Of the 125 individuals in this sample who had published, $63(50 \%)$ had this content in their position description; 40 (34\%) of the 119 non-publishers had this content.

\section{Region 2:}

Publication status: $\chi^{2}=4.29, p<.05$. Chi-square analysis indicates a statistically significant relationship between this content and publication status. The measure of the strength of the relationship, phi $=.37, p<.05$, indicating a moderately strong relationship. Of the 15 individuals in this sample who had published, $12(80 \%)$ had content fitting this sub category in their position description; 7 (44\%) of the 16 non-publishers had this content.

\section{Region 9:}

Publication status: $\chi^{2}=11.06, p<.05$. Chi-square analysis indicates a statistically significant relationship between this content and publication status. The measure of the strength of the relationship, $p h i=.56, p<.05$, indicating a strong relationship. Of the 16 individuals in this sample who had published, $9(56 \%)$ had content fitting this sub category in their position description; 1 (5\%) of the 19 non-publishers had this content. 
Category

(5) Research application

Note: Research application can be used in situations in which a person

did not personally collect the data or is

otherwise not using original data.
Sub category

(2) Use research-based information to inform policy makers*
Definition

Use research-based information to inform policy makers. The document must indicate a specific recipient of the information.

\begin{tabular}{rr|cccc} 
Region & PDs coded with this & $\begin{array}{l}\text { Relationship with } \\
\text { publication status }\end{array}$ & $\begin{array}{l}\text { Relationship with GS } \\
\text { level (limited range) }\end{array}$ & $\begin{array}{l}\text { Relationship with } \\
\text { occupational } \\
\text { classification } \\
\text { (limited range) }\end{array}$ \\
\hline All FWS & 9 of $244(4 \%)$ & - & - & - \\
$\mathbf{1}$ & 1 of $43(2 \%)$ & No & - & - \\
$\mathbf{2}$ & 3 of $31(10 \%)$ & No & - & - \\
$\mathbf{3}$ & 0 of $29(0 \%)$ & - & - & - \\
$\mathbf{5}$ & 1 of $32(3 \%)$ & No & - & - \\
$\mathbf{6}$ & 1 of $38(3 \%)$ & No & - & - \\
$\mathbf{7}$ & 2 of $36(6 \%)$ & No & - & -
\end{tabular}

Notes. - indicates that the data were too sparse to permit testing of a relationship between the variables.

\section{Category}

(5) Research application Note: Research application can be used in situations in which a person did not personally collect the data or is otherwise not using original data.

\section{Sub category}

(3) Use research-based information to formulate decision documents*

\section{Definition}

Use research-based information to formulate Environmental Impact Statements, Environmental Assessments, or other decision documents.

\begin{tabular}{rr|cccc}
\multicolumn{1}{r|}{ Region } & PDs coded with this & $\begin{array}{l}\text { Relationship with } \\
\text { publication status }\end{array}$ & $\begin{array}{l}\text { Relationship with } \\
\text { occupational } \\
\text { classification } \\
\text { (limited range) }\end{array}$ \\
\hline All FWS & 7 of $244(3 \%)$ & - & - & - \\
$\mathbf{1}$ & 1 of $43(2 \%)$ & No & - & - \\
$\mathbf{2}$ & 1 of $31(3 \%)$ & No & - & - \\
$\mathbf{3}$ & 0 of $29(0 \%)$ & - & - & - \\
$\mathbf{5}$ & 0 of $32(0 \%)$ & No & - & - \\
$\mathbf{6}$ & 2 of $38(5 \%)$ & No & - & -
\end{tabular}

Notes. - indicates that the data were too sparse to permit testing of a relationship between the variables. 
Category

(5) Research application

Note: Research application can be used in situations in which a person did not personally collect the data or is otherwise not using original data.
Sub category

(4) Develop new techniques/ technologies/methods for research or analysis.

\section{Definition}

Create a new approach to data collection, or research design.

\begin{tabular}{|c|c|c|c|c|}
\hline Region & $\begin{array}{l}\text { PDs coded with this } \\
\text { sub category }\end{array}$ & $\begin{array}{l}\text { Relationship with } \\
\text { publication status }\end{array}$ & $\begin{array}{l}\text { Relationship with GS } \\
\text { level (limited range) }\end{array}$ & $\begin{array}{l}\text { Relationship with } \\
\text { occupational } \\
\text { classification } \\
\text { (limited range) }\end{array}$ \\
\hline All FWS & 21 of $244(9 \%)$ & No & No & Yes \\
\hline 1 & 1 of $43(2 \%)$ & No & - & - \\
\hline 2 & 3 of $31(10 \%)$ & No & - & - \\
\hline 3 & 1 of $29(3 \%)$ & No & - & - \\
\hline 5 & 0 of $32(0 \%)$ & - & - & - \\
\hline 6 & 3 of $38(8 \%)$ & No & - & - \\
\hline 7 & 7 of $36(19 \%)$ & No & - & - \\
\hline 9 & 6 of $35(17 \%)$ & No & - & - \\
\hline
\end{tabular}

Notes. - indicates that the data were too sparse to permit testing of a relationship between the variables.

\section{All FWS:}

Occupational classification: $\chi^{2}=22.72, p<.05$. Chi-square analysis indicates a statistically significant relationship between this sub category and occupational classification. The measure of the strength of the relationship, Cramer's $\mathrm{V}=.31, p<.05$, indicating a moderately strong relationship. No occupational classification had a substantial proportion of position descriptions with content fitting this sub category. Of the position descriptions with this content, the largest proportion of them were classified as 486-Wildlife Biology $(14 / 19=73 \%)$.

Category

(6) Research collaboration

\section{Sub category}

(1) Collaborate with non-FWS personnel on research projects*

\section{Definition}

Working with any one outside of the FWS on a research project in any capacity.

\begin{tabular}{|c|c|c|c|c|}
\hline Region & $\begin{array}{l}\text { PDs coded with this } \\
\text { sub category }\end{array}$ & $\begin{array}{l}\text { Relationship with } \\
\text { publication status }\end{array}$ & $\begin{array}{l}\text { Relationship with GS } \\
\text { level (limited range) }\end{array}$ & $\begin{array}{l}\text { Relationship with } \\
\text { occupational } \\
\text { classification } \\
\text { (limited range) }\end{array}$ \\
\hline All FWS & 78 of $244(32 \%)$ & Yes & No & Yes \\
\hline 1 & 14 of $43(33 \%)$ & No & - & - \\
\hline 2 & 15 of $31(48 \%)$ & No & - & - \\
\hline 3 & 5 of $29(17 \%)$ & No & - & - \\
\hline 5 & 14 of $32(44 \%)$ & Yes & - & - \\
\hline 6 & 6 of $38(16 \%)$ & No & - & - \\
\hline 7 & 19 of $36(53 \%)$ & No & - & - \\
\hline 9 & 5 of $35(14 \%)$ & Yes & - & - \\
\hline
\end{tabular}

Notes. - indicates that the data were too sparse to permit testing of a relationship between the variables.

\section{All FWS:}

Publication status: $\chi^{2}=10.94, p<.05$. Chi-square analysis indicates a statistically significant relationship between this content and publication status. The measure of the strength of the relationship, $p h i=.21, p<.05$, indicating a moderate relationship. Of the 125 individuals in this sample who had published, $52(42 \%)$ had this content in their position description; 26 (22\%) of the 119 non-publishers had this content.

Occupational classification: $\chi^{2}=11.75, p<.05$. Chi-square analysis indicates a statistically significant relationship between this sub category and occupational classification. The measure of the strength of the relationship, Cramer's $\mathrm{V}=.23, p<.05$, indicating a moderate relationship. None of the occupational classifications analyzed had more than 
$50 \%$ of PDs with this content. Of the position descriptions with this content, the largest proportion of them were classified as 486-Wildlife Biology $(26 / 71=37 \%)$.

\section{Region 5:}

Publication status: $\chi^{2}=4.10, p<.05$. Chi-square analysis indicates a statistically significant relationship between this content and publication status. The measure of the strength of the relationship, $p h i=.36, p<.05$, indicating a moderate strong relationship. Of the 12 individuals in this sample who had published, $8(67 \%)$ had this content in their position description; 6 (30\%) of the 20 non-publishers had this content.

\section{Region 9:}

Publication status: $\chi^{2}=6.93, p<.05$. Chi-square analysis indicates a statistically significant relationship between this content and publication status. The measure of the strength of the relationship, $p h i=.45, p<.05$, indicating a moderately strong relationship. Of the 16 individuals in this sample who had published, 5 (31\%) had content fitting this sub category in their position description; none of the 19 non-publishers had this content.

\begin{tabular}{lll} 
Category & Sub category & Definition \\
\hline (6) Research collaboration & (2) Supervise or coordinate other FWS & Supervising or coordinating among other \\
& employees on research projects* & FWS employees in any aspect of the \\
& research process.
\end{tabular}

\begin{tabular}{|c|c|c|c|c|}
\hline Region & $\begin{array}{l}\text { PDs coded with this } \\
\text { sub category }\end{array}$ & $\begin{array}{l}\text { Relationship with } \\
\text { publication status }\end{array}$ & $\begin{array}{l}\text { Relationship with GS } \\
\text { level (limited range) }\end{array}$ & $\begin{array}{l}\text { Relationship with } \\
\text { occupational } \\
\text { classification } \\
\text { (limited range) }\end{array}$ \\
\hline All FWS & 59 of $244(24 \%)$ & No & No & No \\
\hline 1 & 10 of $43(23 \%)$ & No & - & - \\
\hline 2 & 14 of $31(45 \%)$ & No & - & - \\
\hline 3 & 3 of $29(10 \%)$ & No & - & - \\
\hline 5 & 13 of $32(41 \%)$ & Yes & - & - \\
\hline 6 & 7 of $38(18 \%)$ & No & - & - \\
\hline 7 & 9 of $36(25 \%)$ & No & - & - \\
\hline 9 & 3 of $35(9 \%)$ & No & - & - \\
\hline
\end{tabular}

Notes. - indicates that the data were too sparse to permit testing of a relationship between the variables.

\section{Region 5:}

Publication status: $\chi^{2}=5.40, p<.05$. Chi-square analysis indicates a statistically significant relationship between this content and publication status. The measure of the strength of the relationship, $p h i=.39, p<.05$, indicating a moderately strong relationship. Of the 12 individuals in this sample who had published, $8(67 \%)$ had this content in their position description; 5 (25\%) of the 20 non-publishers had this content.

\begin{tabular}{lll} 
Category & Sub category & Definition \\
\hline (6) Research collaboration & $\begin{array}{l}\text { (3) Identify sources of funding for } \\
\text { research }\end{array}$ & $\begin{array}{l}\text { Identifying sources of funding for } \\
\text { research. }\end{array}$
\end{tabular}

\begin{tabular}{|c|c|c|c|c|}
\hline Region & $\begin{array}{l}\text { PDs coded with this } \\
\text { sub category }\end{array}$ & $\begin{array}{l}\text { Relationship with } \\
\text { publication status }\end{array}$ & $\begin{array}{l}\text { Relationship with GS } \\
\text { level (limited range) }\end{array}$ & $\begin{array}{l}\text { Relationship with } \\
\text { occupational } \\
\text { classification } \\
\text { (limited range) }\end{array}$ \\
\hline All FWS & 3 of $244(1 \%)$ & - & - & - \\
\hline 1 & 0 of $43(0 \%)$ & - & - & - \\
\hline 2 & 0 of $31(0 \%)$ & - & - & - \\
\hline 3 & 0 of $29(0 \%)$ & - & - & - \\
\hline 5 & 1 of $32(3 \%)$ & No & - & - \\
\hline 6 & 2 of $38(5 \%)$ & No & - & - \\
\hline 7 & 0 of $36(0 \%)$ & - & - & - \\
\hline 9 & 0 of $35(0 \%)$ & - & - & - \\
\hline
\end{tabular}

Notes. - indicates that the data were too sparse to permit testing of a relationship between the variables. 
Category

(6) Research collaboration
Sub category

(4) Write research funding proposals
Definition

Writing research grant or other funding proposals.

\begin{tabular}{|c|c|c|c|c|}
\hline Region & $\begin{array}{l}\text { PDs coded with this } \\
\text { sub category }\end{array}$ & $\begin{array}{l}\text { Relationship with } \\
\text { publication status }\end{array}$ & $\begin{array}{l}\text { Relationship with GS } \\
\text { level (limited range) }\end{array}$ & $\begin{array}{l}\text { Relationship with } \\
\text { occupational } \\
\text { classification } \\
\text { (limited range) }\end{array}$ \\
\hline All FWS & 6 of $244(3 \%)$ & - & - & - \\
\hline 1 & 0 of $43(0 \%)$ & - & - & - \\
\hline 2 & 5 of $31(16 \%)$ & No & - & - \\
\hline 3 & 0 of $29(0 \%)$ & - & - & - \\
\hline 5 & 0 of $32(0 \%)$ & - & - & - \\
\hline 6 & 1 of $38(3 \%)$ & No & - & - \\
\hline 7 & 0 of $36(0 \%)$ & - & - & - \\
\hline 9 & 0 of $35(0 \%)$ & - & - & - \\
\hline
\end{tabular}

Notes. - indicates that the data were too sparse to permit testing of a relationship between the variables.

\section{Category}

(7) Knowledge/skill/ability required
Sub category

(1) Knowledge/skill/ability - statistical data analysis

\section{Definition}

This position requires knowledge/skill/ability in data analysis techniques and methods.

\begin{tabular}{rr|rccc}
\multicolumn{1}{r|}{ Region } & PDs coded with this & Relationship with & & \multicolumn{1}{c}{$\begin{array}{l}\text { Relationship with } \\
\text { occupational } \\
\text { classification } \\
\text { (limited range) }\end{array}$} \\
\hline AlI FWS & publication status & $\begin{array}{l}\text { Relationship with GS } \\
\text { level (limited range) }\end{array}$ & Yes \\
$\mathbf{1}$ & 22 of $43(51 \%)$ & Yes & No & - & - \\
$\mathbf{2}$ & 10 of $31(32 \%)$ & No & No & - & - \\
$\mathbf{3}$ & 4 of $29(14 \%)$ & Yes & - & - \\
$\mathbf{5}$ & 14 of $32(44 \%)$ & No & - & - \\
$\mathbf{6}$ & 18 of $38(47 \%)$ & No & - & -
\end{tabular}

Notes. - indicates that the data were too sparse to permit testing of a relationship between the variables.

\section{All FWS:}

Publication status: $\chi^{2}=9.22, p<.05$. Chi-square analysis indicates a statistically significant relationship between this content and publication status. The measure of the strength of the relationship, $p h i=.19, p<.05$, indicating a moderate relationship. Of the 125 individuals in this sample who had published, $65(52 \%)$ had this content in their position description; 39 (33\%) of the 119 non-publishers had this content.

GS level: $\chi^{2}=15.88, p<.05$. Chi-square analysis indicates a statistically significant relationship between this sub category and GS Level. The measure of the strength of the relationship, Cramer's V $=.27, p<.05$, indicating a moderately strong relationship. More than half of the individuals in GS levels $11(30 / 55=55 \%)$, and $12(41 / 78=$ 53\%) had content fitting this sub category in their position descriptions.

Occupational classification: $\chi^{2}=44.16, p<.05$. Chi-square analysis indicates a statistically significant relationship between this sub category and occupational classification. The measure of the strength of the relationship, Cramer's $\mathrm{V}=.44, p<.05$, indicating a strong relationship. None of the occupational classifications analyzed had more than $50 \%$ of PDs with this content. Of the position descriptions with this content, the largest proportion of them were classified as 486-Wildlife Biology $(47 / 97=48 \%)$. 


\title{
Region 5:
}

Publication status: $\chi^{2}=4.10, p<.05$. Chi-square analysis indicates a statistically significant relationship between this content and publication status. The measure of the strength of the relationship, $p h i=.36, p<.05$, indicating a moderately strong relationship. Of the 12 individuals in this sample who had published, $8(67 \%)$ had this content in their position description; 6 (30\%) of the 20 non-publishers had this content.

\section{Region 9:}

Publication status: $\chi^{2}=4.72, p<.05$. Chi-square analysis indicates a statistically significant relationship between this content and publication status. The measure of the strength of the relationship, $p h i=.37, p<.05$, indicating a moderate relationship. Of the 16 individuals in this sample who had published, $8(50 \%)$ had content fitting this sub category in their position description; 3 (16\%) of the 19 non-publishers had this content.

Category

(7) Knowledge/skill/ability required
Sub category

(2) Knowledge/skill/ability - research methods
Definition

\section{This position requires}

knowledge/skill/ability in research methods, including data collection techniques and study design.

\begin{tabular}{rr|cccc}
\multicolumn{1}{r|}{ Region } & Yes & & & \multicolumn{1}{c}{$\begin{array}{l}\text { Relationship with } \\
\text { occupational } \\
\text { classification } \\
\text { (limited range) }\end{array}$} \\
\hline All FWS & $\begin{array}{l}\text { PDs coded with this } \\
\text { sub category }\end{array}$ & $\begin{array}{l}\text { Relationship with } \\
\text { publication status }\end{array}$ & $\begin{array}{l}\text { Relationship with GS } \\
\text { level (limited range) }\end{array}$ & No & Yes \\
$\mathbf{1}$ & 22 of $43(51 \%)$ & Yes & - & - & - \\
$\mathbf{2}$ & 17 of $31(55 \%)$ & No & - & - \\
$\mathbf{3}$ & 6 of $29(21 \%)$ & No & No & - & - \\
$\mathbf{5}$ & 15 of $32(47 \%)$ & No & - & - \\
$\mathbf{6}$ & 21 of $38(55 \%)$ & Yes & - & -
\end{tabular}

Notes. - indicates that the data were too sparse to permit testing of a relationship between the variables.

\begin{abstract}
All FWS:
Publication status: $\chi^{2}=14.91, p<.05$. Chi-square analysis indicates a statistically significant relationship between this content and publication status. The measure of the strength of the relationship, $p h i=.25, p<.05$, indicating a moderate relationship. Of the 125 individuals in this sample who had published, $75(60 \%)$ had this content in their position description; 42 (35\%) of the 119 non-publishers had this content.
\end{abstract}

Occupational classification: $\chi^{2}=42.16, p<.05$. Chi-square analysis indicates a statistically significant relationship between this sub category and occupational classification. The measure of the strength of the relationship, Cramer's $\mathrm{V}=.43, p<.05$, indicating a strong relationship. None of the occupational classifications analyzed had more than $50 \%$ of PDs with this content. Of the position descriptions with this content, the largest proportion of them were classified as 486-Wildlife Biology $(45 / 109=41 \%)$.

\section{Region 1:}

Publication status: $\chi^{2}=5.22, p<.05$. Chi-square analysis indicates a statistically significant relationship between this content and publication status. The measure of the strength of the relationship, $p h i=.35, p<.05$, indicating a moderately strong relationship. Of the 22 individuals in this sample who had published, 15 (68\%) had content fitting this sub category in their position description; 7 (33\%) of the 21 non-publishers had this content.

\section{Region 7:}

Publication status: $\chi^{2}=6.36, p<.05$. Chi-square analysis indicates a statistically significant relationship between this content and publication status. The measure of the strength of the relationship, $p h i=.42, p<.05$, indicating a moderately strong relationship. Of the 23 individuals in this sample who had published, 17 (74\%) had this content in their position description; 4 (31\%) of the 13 non-publishers had this content. 


\section{Region 9:}

Publication status: $\chi^{2}=4.64, p<.05$. Chi-square analysis indicates a statistically significant relationship between this content and publication status. The measure of the strength of the relationship, $p h i=.36, p<.05$, indicating a moderate relationship. Of the 16 individuals in this sample who had published, $10(63 \%)$ had content fitting this sub category in their position description; 5 (26\%) of the 19 non-publishers had this content.

\section{Category}

(7) Knowledge/skill/ability required

\section{Sub category}

(3) Knowledge/skill/ability - statistical software

\section{Definition}

This position requires knowledge/skill/ability in use of statistical software packages.

\begin{tabular}{|c|c|c|c|c|}
\hline Region & $\begin{array}{l}\text { PDs coded with this } \\
\text { sub category }\end{array}$ & $\begin{array}{l}\text { Relationship with } \\
\text { publication status }\end{array}$ & $\begin{array}{l}\text { Relationship with GS } \\
\text { level (limited range) }\end{array}$ & $\begin{array}{l}\text { Relationship with } \\
\text { occupational } \\
\text { classification } \\
\text { (limited range) }\end{array}$ \\
\hline All FWS & 27 of $244(11 \%)$ & Yes & No & No \\
\hline 1 & 5 of $43(12 \%)$ & No & - & - \\
\hline 2 & 3 of $31(10 \%)$ & No & - & - \\
\hline 3 & 3 of $29(10 \%)$ & No & - & - \\
\hline 5 & 2 of $32(6 \%)$ & No & - & - \\
\hline 6 & 2 of $38(5 \%)$ & No & - & - \\
\hline 7 & 11 of $36(31 \%)$ & No & - & - \\
\hline 9 & 1 of $35(3 \%)$ & No & - & - \\
\hline
\end{tabular}

Notes. - indicates that the data were too sparse to permit testing of a relationship between the variables.

\section{All FWS:}

Publication status: $\chi^{2}=4.45, p<.05$. Chi-square analysis indicates a statistically significant relationship between this content and publication status. The measure of the strength of the relationship, $p h i=.14, p<.05$, indicating a weak relationship. Of the 125 individuals in this sample who had published, $19(15 \%)$ had this content in their position description; 8 (7\%) of the 119 non-publishers had this content.

\section{Category}

(7) Knowledge/skill/ability required

\section{Sub category}

(4) Knowledge/skill/ability - document preparation

\section{Definition}

This position requires knowledge/skill/ability to write reports, papers, manuscripts based on research for dissemination or publication.

\begin{tabular}{|c|c|c|c|c|}
\hline Region & $\begin{array}{l}\text { PDs coded with this } \\
\text { sub category }\end{array}$ & $\begin{array}{l}\text { Relationship with } \\
\text { publication status }\end{array}$ & $\begin{array}{l}\text { Relationship with GS } \\
\text { level (limited range) }\end{array}$ & $\begin{array}{l}\text { Relationship with } \\
\text { occupational } \\
\text { classification } \\
\text { (limited range) }\end{array}$ \\
\hline All FWS & 58 of $244(24 \%)$ & No & Yes & No \\
\hline 1 & 7 of $43(16 \%)$ & No & - & - \\
\hline 2 & 8 of $31(26 \%)$ & No & - & - \\
\hline 3 & 8 of $29(28 \%)$ & No & - & - \\
\hline 5 & 13 of $32(41 \%)$ & No & - & - \\
\hline 6 & 10 of $38(26 \%)$ & No & - & - \\
\hline 7 & 11 of $36(31 \%)$ & Yes & - & - \\
\hline 9 & 1 of $35(3 \%)$ & No & - & - \\
\hline
\end{tabular}

Notes. - indicates that the data were too sparse to permit testing of a relationship between the variables.

\section{All FWS:}

GS level: $\chi^{2}=7.96, p<.05$. Chi-square analysis indicates a statistically significant relationship between this sub category and GS Level. The measure of the strength of the relationship, Cramer's V $=.19, p<.05$, indicating a moderate relationship. None of the GS levels had more than half of the PDs with content fitting this sub category. Of the position descriptions that did have this content, the largest proportion $(23 / 53=43 \%)$ were GS-12. 


\section{Region 7:}

Publication status: $\chi^{2}=8.95, p<.05$. Chi-square analysis indicates a statistically significant relationship between this content and publication status. The measure of the strength of the relationship, $p h i=.50, p<.05$, indicating a moderately strong relationship. Of the 23 individuals in this sample who had published, 11 (48\%) had this content in their position description; 0 of the 13 non-publishers had this content. 


\section{Appendix 4A. Responses to Open-ended Question Asking All Respondents for Other Comments}

Below are the responses to the final question on the FWS survey: "Please tell us if you have any other comments, suggestions, or information."

Two-hundred respondents to the survey took the opportunity to answer this open ended question. The responses were sorted into categories and when appropriate, sub-categories. Each of the numbered comments is the complete response provided by an individual. Often, the content of a response fell into more than one category. In these cases, the response appears in multiple categories in its entirety so that no single comment can be taken out of context. All percentages are rounded to whole numbers.

The categories of content are as follows:

Primary category: Comments regarding the survey

Sub-category: General positive comments

Sub-category: General negative comments

Sub-category: Survey questions not applicable to respondent

Sub-category: Criticism of specific questions or response options

Primary category: Comments regarding the respondent's background as it may apply to the survey

Sub-category: Time in job

Sub-category: Other agency experience

Sub-category: Amount of research content in their job

Sub-category: Type of research content in their job

Sub-category: Miscellaneous comments regarding respondent's background

Primary category: Comments regarding research in the FWS

Sub-category: Necessity of research in the FWS

Sub-category: Resources for research in the FWS

Sub-category: Outside influences on research in the FWS

Sub-category: Perceptions of FWS as a research agency

Primary category: Miscellaneous comments

Primary category: Comments regarding the survey

$25 \%$ of respondents' comments $\left(63^{\mathrm{a}} / 250\right)$ contained content reflected in this category.

ane comment appears in two subcategories of this primary category, therefore the comments number 63 and not 64 . 


\section{General positive comments \\ $6 \%$ of comments from all respondents $(16 / 250)$ \\ $25 \%$ of respondents commenting regarding the survey (16/63)}

(13) The service has a long tradition of excellent science that continues to the present day. However, the questioning of our science due to a political agenda is very disconcerting for all involved. To add to staff's frustration is the perception that BRD should do research which leaves the perception that the service does "hobby science" (see previous comments). As a side note, I know that refuges "is" the service, but as a non-refuge employee, it is very disturbing to see the blue goose side by side with the service logo as if refuges was an equal partner (as another agency would be) with the service instead of a program within the service. Signs/symptoms such as this add to the disillusionment/confusion as to how do non-refuge programs fit within the service and reduce camaraderie among programs that used to be within the service. Thanks for the opportunity to comment. I look forward to seeing the results.

(20) Given above, why not just ask my name? Kidding aside, thank you for being introspective about research and biological programs of FWS, I hope you have excellent cooperation in this survey endeavor and I look forward to the results.

(23) Thank you for focusing on this important topic.

(34) Thanks for your interest.

(48) Thank you for asking from a long-term, seasonal employee. Desire is the project and not the pay check. Can't live in that unreal world much longer...student loans are not getting chunked out as a gs-7. Might be jumping ship to go work for USGS. Would rather stay with this agency and be part of the return of research within the FWS, to complement and collaborate with USGS, academia and non-profits. Cheers

(49) Thanks for the opportunity to participate in the survey.

(66) Interesting survey.

(123) Again, not sure whether the results from my questionnaire will be useful. After taking the questionnaire, my answer up front maybe should have been that I don't conduct research although I do analyze data. However, I'm glad that an effort has been made to seek more information about FWS research. I was under the impression that after region 8 was moved to USGS, the FWS was no longer to conducted research. After reading this questionnaire, looks like I was wrong.

(149) I hope you get some good information from this survey.

(182) In addition to needing more time and financial resources to conduct research (who doesn't?), additional educational opportunities to remain current or obtain advanced degrees more aligned with increasing research complexity could be beneficial. Thank you for conducting this survey and providing the opportunity to respond. The results will be most interesting.

(190) Would appreciate receiving a copy of survey results. Hopefully these promote some change in the institution. One other point: it would be useful if the service could establish a more effective institutional (and funding) framework for science support. Prime example of an effective top-down initiative is the national park service's natural resource inventory and monitoring program.

(199) That this survey is being conducted is a positive sign. Please disseminate the results.

(205) Just reorganized and was re-assigned branch chief for "applied science" (fewer responsibilities for research in this capacity). Other comments: I am a lead in monitoring an endangered species (population trends \& habitat modeling) some do not consider monitoring as research per se. For the purposes of this survey, I am considering statistically valid monitoring as research. From my perspective, the FWS has lost the capacity to do scientifically credible research since it lost its research branch. Sure there are a few isolated individuals or groups who are involved with research activities, but generally speaking FWS does not do research (i.e. Hypotheses testing). There is shoe string work going on willy-nilly that those who are doing thing they are doing research, but in reality they are doing descriptive studies, or their work lacks a statistically valid/rigorous design (i.e. Most is not publishable). Lee, you are more than welcome to give me a call if you want to discuss the survey further. [name deleted] (p.s. well organized and thoughtful survey!)

(236) I am responsible for designing courses for the FWS addressing the use of science in decision making and conservation planning for endangered species. I am the design team leader and coordinate the efforts of scientifics from several agencies \& universities. While not actively involved in research myself, I am acutely aware of the scientific skills required of FWS staff and encourage increased participation of USGS scientists in assisting/supporting FWS staff in practice and in providing training. I am very interested in results of your survey and hope it will be available to FWS staff soon. 
(237) Good questions, look forward to seeing a summary.

(245) Institutional lack of support for publishing in peer-reviewed journals. FWS does not value scientists. Thanks for the opportunity to comment. 11. Despite job being $90 \%$ research, FWS refuses to acknowledge it on paper and keeps my title in management services. Hence, there is no career path for me by conducting research. Publication in peer-reviewed journals is not rewarded or encouraged by FWS. I appealed my title, but lost. Region 6 - fisheries clearly does not want its biologists to be classed as researchers even though in my case, essentially all of my funding comes from the Colorado river recovery program rather than FWS base funds. Part of the problem is that administrators at regional level do not have a research background and do not understand its importance. Also, many decisions within agency are increasingly based on political consideration rather than on sound science, hence, science is under-valued.

\section{General negative comments \\ $4 \%$ of comments from all respondents $(11 / 250)$ \\ $17 \%$ of respondents commenting regarding the survey $11 / 63$ )}

\section{Sub-theme: Definition of research}

(125) Based upon the questions, I am not sure that this survey was intended to include planning type "research" (i.e. Data gathering to write a CCP, EA, EIS). However, it is from the planning viewpoint that this survey was answered.

(133) Research should be better defined for your survey purposes.

(188) Because of the inconsistent references to "conduct research" in the survey, I found myself uncertain how to respond to some questions. I decided to use the broad definition provided at the beginning of the survey when answering, even though some of the questions seemed to imply an association to direct research delivery activities. I would suggest that these uncertainties be recognized in the survey report so that the data can be viewed in the broadest context.

\section{Sub-theme: Technical issues}

(32) You should allow people responding to the survey to be completely anonymous - e.g., do not request any personal info. and do not invite people, by name, to take the survey. It's not an issue for me, because I'm happy with my job and with the status of research in my division. But, if I had lots of complaints, I may be hesitant to voice them knowing that my name is (at least initially) attached to my responses.

(47) The survey should allow us to print a hardcopy of our answers.

(143) I sent lee an email with comments. For some reason this page was not available after I finished section 6.

(225) The website was slow and not user friendly! Thus, I completed this. [name deleted]

(230) I didn't complete this online because I put yes on the first question by mistake and was not able to go back and change the answer.

(234) Well, it's time to gripe! I tried the on-line version and had quite a few problems, between how incredibly slow it was after clicking the continue arrows to getting two error messages, I was pretty frustrated. I wasn't confident in the online program before the second error message shut me down. Well, I decided to do the PDF version and the whole thing only took me 15 minutes. On-line surveys seem so frustrating because of how slow they are and error messages or even programs locking up. I was asked recently to do another survey and I didn't because of the hassles and time commitments. I almost "blew-off" this one as well, but decided to in the end as it was more directed to /by the service. I, and others, are always glad to help out. But, we'd sure like less hassles in these processes!!!

(246) When offering a web based survey - make sure it works! I was booted off twice, once when I had partially completed the survey. Many folks would have not completed the survey after this experience.

(247) As I supervise field stations who conduct research, I have answered questions for those stations. I have not performed research for $20+$ years. The service desperately needs a career track for scientists/researchers so we can retain their research skills. To get ahead, you must go into management with ABC, RPI and KPMG audits to name a few. We spend an increasing amount of management and staff time of administrative and not science or even policymaking that is a result of scientific endeavors. After looking at this, it is set up wrong. If a person checks the last item on page 2, "supervise or coordinate the efforts of there FWS employees...." They should go to track 2 and not track 1 . The web site has been down today (11/24/04). I reported it. 


\section{Miscellaneous:}

(25) What is the purpose of this survey: more to USGS or more research back to the FWS?

\section{Survey questions not applicable to respondent $9 \%$ of comments from all respondents $(22 / 250)$ $35 \%$ of respondents commenting regarding the survey $(22 / 63)$}

(3) My position does not involve conducting research; therefore most of the questions in this survey were left blank.

(15) Questions were hard to answer as I actually supervise a refuge biologist who conducts what research we do here.

(43) most questions designed for people who spend most of their time as researchers

(87) This survey is more applicable for wildlife biologist than refuge managers. In addition, we were told years ago that biologist on refuges should not be doing research unless it was in cooperation with USGS or with universities taking the lead. Refuge biologists are supposed to collect data only on monitoring type studies that are not considered research. Perhaps this policy changed without my knowledge but that is the way I understood it as an employee with FWS.

(97) I am not comfortable that the survey accurately portrays what I or my counterparts do. We must be experts for our lead species, and as such direct research including preparation and review of proposals, review and interpretation of data, and scientific judgments. I (we) rarely am afforded the opportunity to conduct field investigations, though we must be on top of the literature. Frequently, research is just the beginning. Thereafter, we have to explain it and sell it to our many state and non-governmental partners.

(111) The design of this survey leaves much to be desired. You ask in the first section if the respondent supervises someone doing research. If the answer is yes, then you were to continue with the survey which asked questions about conducting research, which few supervisors do. If you answered yes to the supervisory question, you should have had the option to continue with the survey if you also conduct research or stop if you only supervise researchers. Given the design of the survey, the results are suspect.

(123) Again, not sure whether the results from my questionnaire will be useful. After taking the questionnaire, my answer up front maybe should have been that I don't conduct research although I do analyze data. However, I'm glad that an effort has been made to seek more information about FWS research. I was under the impression that after region 8 was moved to USGS, the FWS was no longer to conducted research. After reading this questionnaire, looks like I was wrong.

(124) Actually this entire survey is not a very good fit for me. I submitted on the first page that I am only involved in research through the supervision of an individual, which apparently qualified me to answer all the questions asked directly of researchers. Since there were few "does not apply" answers including, my survey would only tend to skew the results.

(141) Most questions do not apply to my position. We are building a better refuge science program, engaged in multirefuge studies and improving our biological data collection and use processes; my work is more of supervisory nature, not hands on.

(161) The questions are a poor fit for those in supervisory roles.

(163) I probably should not have done this survey, but I supervise a couple of staff who have some involvement in research, albeit mostly supporting others, rather than doing it themselves. It would have been more meaningful if there were another category for supervisors, who don't do research themselves.

(169) I started taking this survey thinking that I could get it to apply to my everyday work, but was unsuccessful. I do not conduct research as a part of my current position, but I do commend those that do.

(174) Much of this survey really doesn't apply to my dealings with research very well

(180) I answered yes to the question in section 1 regarding whether I conduct research because you included monitoring, writing reports, analyzing data, etc. Those activities are the main components of my job. However, I am mainly involved in annual population and productivity surveys that were designed by others, and I have had very little involvement with survey design, obtaining funds or partnering with other agencies/NGO. Therefore I feel that many of the questions in this survey don't really apply to me. Also, in the section on publications, I responded that I never presented results in "publications of FWS or other agencies." I assumed you meant true publications, e.g. The technical report series, and not unpublished agency reports. (I write many of those).

(187) Your questionnaire is not really geared to those who coordinate research. 
(200) This questionnaire was hard for I answer as I commented before. I feel that you should not have had the selection of supervising as all of the questions deal with research and as a project leader I do not conduct my own research.

(201) I fall between your track 1 and track 2 - I am collaborating with other agencies and university researchers on a project and have collected some data and contributed to the study design and have been involved in the funding process, but not to the extent listed. My supervisor is supportive, and is also involved. For future questionnaires online, it would be useful for those of us who have the questions "sort of" apply to be able to go back to the initial page of activities to change our answers. (Which is why I'm mailing this in, rather than completing it online, as I started to do?)

(215) My job duties as an oil and gas specialist don't really require in-depth research on my part. I don't know if this questionnaire pertains to me as much as it would if I had a "typical" wildlife biologist position

(217) This station remains committed to applied research projects that will improve management and we will do what we have do to see this type of work continue - but it is a struggle - you have to want it very much to make it happen. I understand why many give up - increasing administrative burdens and restrictions drain your "on the ground efforts" and emotions. Section 2: I probably should not have answered this section since I have minimal involvement in actual research. But, I have initiated studies, found \$, students, partners for research. If I wasn't involved and committed many of these projects and others would not have happened. Section 3.2: 5\% actual research, I am a manager who strongly supports research. I seek funds, partnerships, students, etc. Refuge biologist and others do actual work. Station biologist, $\mathrm{ms} / \mathrm{PhD}$ students, coop. Research. Investigators do work requested.

(223) The questions in this survey do not apply to my position. I supervise biologists, fire staff, foresters, and public use employees that may be involved in research activities. These questions seemed designed for them. However, no funding is available for research and limited staff makes research a very low priority.

(233) This survey has nothing to do with my job duties and responsibilities.

(241) Currently, all of my "research" activity is endangered species monitoring as just part of my job. Therefore, some of the questions in the survey did not seem very applicable to my situation, mainly in regard to my position. My job is refuge management and I do not have a research emphasis. However, if research is needed I feel there is a good atmosphere for getting it done.

\section{Criticism of specific questions or response options $6 \%$ of comments from all respondents $(14 / 250)$ $22 \%$ of respondents commenting regarding the survey (14/63)}

(19) In section 2 on the question about the source of my research funds I put $100 \%$ in the base funded category just so I could get out of the box. I don't do research so I have no funds for that purpose from any source.

(70) On the question about how we get research funds, one option was base funding, but there are some nuances about our definition of "base" which in our case is pitifully small. There are other opportunities within the division of refuges, like challenge cost share, whereby non-federal partners contribute at least $50 \%$ and the regional office (refuges) contributes the remainder. This is different from base funds in my opinion and provides significant opportunities for research that would not occur if we had to rely on "base" funds.

(79) The answer above about adding research responsibilities suggests that I do more research. Actually, I do little, but just have more done by others on the refuge (staff and universities).

(114) This survey was too long and had questions where I had to make up numbers because I couldn't leave them blank. The amount of budget spent on research question is an example. I have no idea how much of the station's budget is spent on research and where it comes from, so you can delete those answers.

(117) I had a difficult time answering some of the survey questions for multiple reasons. Part of the problem related to questions about definitions (types, levels) of research and support. Thus, I did not always feel like I was able to answer questions appropriately.

It would be interesting to see a comparison of survey responses among different levels (national, regional, field) and divisions/offices (e.g., refuges, ecosystem services, and migratory birds) of the FWS. Further, it would be interesting to see how other groups (outside the FWS) view science in the FWS.

(120) Several questions of this survey do not include an appropriate response option covering all possibilities. At the very least, a NA might be required for some. It also lacks some important questions or appears to assume that only certain situations exist within the FWS, so that the results may be incomplete. Some of these likely relate to the situation I describe in the comments of the last section. 
(129) The funding page of this questionnaire did not include an option that I would have chosen - tribal funding.

(131) The last question in section 4 was confusing. I was to answer "yes" or "no" to "not applicable" to me. I do not publish or present research results." Since that section was applicable to me and I do those things, I answered "no," but the double negatives were weird.

(135) In regards to my answer of the preceding question, the added research responsibilities have been self-generated, not developed or imposed by my supervisors. As with many such surveys, the template for answering some questions did not always suit the questions being asked. For example, some questions do not apply to and/or adequately describe the situation being asked about. As a result, it is not clear how to answer those questions. For example, for some questions, a "neutral" response could mean that you don't feel strongly about the issue, the issue doesn't apply to you at all, or that the answers provided do not adequately capture your response to the question. Therefore, a single response type (e.g., "neutral") could actually mean three different things to the survey subjects, but will be treated uniformly by the surveyor when he/she summarizes and synthesizes the data. As a result, a lot of potentially useful information is lost to the surveyor. Of course, it is difficult to be simultaneously comprehensive and streamlined with this type of effort, so format and question limitations are, of necessity, compromises.

(138) The questions regarding communication of research results was difficult to answer as all of the research that is funded under the grant programs I am involved with is published/presented in some format - however, I am never the author or speaker - but serve as a reviewer of the study results.

(153) I believe the survey should have had more focus on the applied aspects of fisheries offices activities. In particular, how does the activities we are engaged in help or influence in inter-jurisdictional activities, multi-state or multi-agency management activities, and etc.

(160) The questions asked in previous sections do not seem straight forward. I would rephrase or remove the likely, unlikely questions, to something more straight forward and clear.

(186) This questionnaire should include "non-applicable" (n/a) as a response option.

(208) Survey would be more useful if there was more focus and inclusion on use of the existing scientific literature to answer management questions of interest. This is a very fundamental and basic use of research within the service. Also would have been better to focus questions on research completion. In my experience, many projects are good at data gathering but often data sits in drawers or files and never gets analyzed, summarized, and used in management.

Primary category: Comments regarding the respondent's background as it may apply to the survey $24 \%$ of respondents' comments $(59 / 250)$ contained content reflected in this category.

\section{Time in job}

$3 \%$ of comments from all respondents $(7 / 250)$

$12 \%$ of respondents commenting regarding respondent's background (7/59)

(9) This questionnaire was difficult for me because I have only been in my present position where I support the field (office based) for the last 2 months. I spent the last 14 years in the field.

(38) I am very new to the FWS and am not sure you should be using me in this survey.

(108) Have only been with FWS since June 1, came from USGS. Conducted research only at USGS, but was impressed by research opportunities with FWS. Was disappointed to find that no budget/personnel were available for research in FWS. Not likely to leave this job within 6 months, but may start looking.

(115) I have only been a biologist for the last year, in that time good research support.

(136) $25 \mathrm{yrs}$ if you include the NBS/USGS screw-up

(159) I am new to the FWS. I worked with another federal agency for 20 years.

(206) I'm quite new to this position, therefore my answers refer to research I expect to conduct in the coming year. In my previous position (with USFWS ecological services) opportunities for research were negligible, and led me to seek my current position (refuges). 


\section{Other agency experience \\ $4 \%$ of comments from all respondents $(9 / 250)$ \\ $15 \%$ of respondents commenting regarding respondent's background (9/59)}

(12) Previous experience in conducting research includes eight years as a fisheries biologist specializing in salmonid otolith microstructural analyses. Experience obtained in Seattle, Washington working for the 'national biological service: western fisheries research center' for the first two years and then began working for the 'skagit system cooperative' for the remaining time. Became a fisheries field biologist in 2001 and was given research responsibilities for the last two years by this office.

(17) I answered the questions from the standpoint of the wildlife biologist position that I served in since 1998. I was promoted to RM less than a year ago.

(21) I accepted my current position with the FWS about 4.5 years ago, after having a similar position with the state of Alaska for over 10 years. There are no other positions for me to move to, unless I want to move into a purely management position.

(55) I moved from BLM to my current FWS position in large part because it included more research responsibilities.

(67) Work included two years with region 8, FWS research prior to its transfer to USGS. Previous work experience at state and private facilities. Assistant manager

(83) I was the chemical contaminants biologist for 16 years. In the past three years I became the coordinator for the Florida gulf coastal program. I am retiring in January, 2005 to take a position as executive director of a local coastal management program.

(91) I moved from USGS-BRD to the service

(99) I came to the service after 17 years doing research and monitoring on the great lakes with us EPA. Would love to see more (actually any) career advancement paths for researchers

(139) I was a research biologist in the fish and wildlife service for the first $25+$ years of my 38 years with the service.

\section{Amount of research content in job $10 \%$ of comments from all respondents $(24 / 250)$ $41 \%$ of respondents commenting regarding respondent's background (24/59)}

(11) My current position has more research opportunities than my previous one, but whether that ends up being the case is yet to be seen.

(29) I have fewer research responsibilities due to cuts in funding and other management needs.

(44) It should be noted that at this time I am working in a capacity where I am more of a data manager than a researcher. If it was my desire to perform more research, I would likely need to seek out additional funding sources and request research-oriented projects from my supervisor. At this time, I do not choose to do so, since I am enjoying working parttime.

(45) Only one on site at current station, took the job thinking I would have more opportunity for biology, but it turned out not to be the case. In my prior position as a wildlife biologist the encouragement and staff support was more for public use and less on biology, unfortunately the thinking was that biology could wait.

(75) I have just started in a job that has more research potential, so most of the answers received in this survey are from two research projects conducted within my first 10 years in FWS. Hopefully opportunities to conduct research will increase. Unfortunately base funding is tight and appears to be getting tighter, and partner's money also seems to be disappearing.

(85) Over the course of my career, my job has evolved from field biologist (undertaking monitoring and research tasks) to project manager (defining and overseeing these tasks, utilizing results in mgmt. Decisions). I understand this as a natural progression of duties and responsibilities, and while I may "fantasize" about the "good old days" of field work, I do not regret the decisions that I have made that have lead to this transition. I value the opportunity I have to apply that which I have learned through practical experience to policy and management decisions. I believe that if the need for more direct involvement in research returns to me, I could leave FWS for academic pursuits...it's clear to me that I'm making choices that balance conflicting interests by advancing my FWS career. 
(104) I have remained in essentially the same job, but my research responsibilities have neither increased nor decreased.

(106) I don't do any "research" although we are always looking at ways to improve the results of what we do.

(121) I have changed jobs but both require about the same amount of research.

(132) Ok, I probably screwed up your survey. I filled this out from the prospective of my previous job. The one I have now has no research or wildlife responsibility at all. I'm misclassified, really, but would love to function as a wildlife biologist, with research responsibilities, again some day.

(135) In regards to my answer of the preceding question, the added research responsibilities have been self-generated, not developed or imposed by my supervisors. As with many such surveys, the template for answering some questions did not always suit the questions being asked. For example, some questions do not apply to and/or adequately describe the situation being asked about. As a result, it is not clear how to answer that question. For example, for some questions, a "neutral" response could mean that you don't feel strongly about the issue, the issue doesn't apply to you at all, or that the answers provided do not adequately capture your response to the question. Therefore, a single response type (e.g., "neutral") could actually mean three different things to the survey subjects, but will be treated uniformly by the surveyor when he/she summarizes and synthesizes the data. As a result, a lot of potentially useful information is lost to the surveyor. Of course, it is difficult to be simultaneously comprehensive and streamlined with this type of effort, so format and question limitations are, of necessity, compromises.

(145) Within the past five years, I have written 4 biological research proposals to address wildlife management issues but have not received funding to conduct the research.

(146) I have changed jobs and still have no research responsibilities. Most of the "research responsibilities" I may have is to assist with monitoring relative to impacts of federal actions. I have recently moved on opportunities for research that should assist with recovery implementation and planning.

(154) Again, I am not in a research type position.

(164) I am on a detail with more research responsibilities.

(173) There are no research responsibilities in my job. All of my research is self motivated and very basic. I mainly monitor fire effects on a variety of plant communities and insect populations using variations in timing and fire intensity. I simply want to further my knowledge of fire effects that are not clearly stated in the literature.

(198) While most of my responsibilities during the past six years have been to compile and analyze data collected by others (production of biological opinions, EIS); I also have participated in research conducted principally by others in this office. I now have inherited those responsibilities (due to retirement and other staff departures) with no reduction in my other duties. I feel quality research is crucial to the service meeting its management goals and obligations, but staffing and monetary constraints limit the production of useful information. Although this may not be specifically pertinent to your survey, it has been my experience (especially during recent years) that politics, more than science, drives management decisions in the service. For biologists at mid-management levels and below, this is very disheartening.

(201) I fall between your track 1 and track 2 - I am collaborating with other agencies and university researchers on a project and have collected some data and contributed to the study design and have been involved in the funding process, but not to the extent listed. My supervisor is supportive, and is also involved. For future questionnaires online, it would be useful for those of us who have the questions "sort of" apply to be able to go back to the initial page of activities to change our answers. (This is why I'm mailing this in, rather than completing it online, as I started to do.)

(205) Just reorganized and was re-assigned branch chief for "applied science" (fewer responsibilities for research in this capacity). Other comments: I am a lead in monitoring an endangered species (population trends \& habitat modeling) some do not consider monitoring as research per se. For the purposes of this survey, I am considering statistically valid monitoring as research. From my perspective, the FWS has lost the capacity to do scientifically credible research since it lost its research branch. Sure there are a few isolated individuals or groups who are involved with research activities, but generally speaking FWS does not do research (i.e. Hypotheses testing). There is shoe string work going on willy-nilly that those who are doing thing they are doing research, but in reality they are doing descriptive studies, or their work lacks a statistically valid/rigorous design (i.e. Most is not publishable). Lee, you are more than welcome to give me a call if you want to discuss the survey further. [name deleted] (p.s. Well organized and thoughtful survey!)

(212) I've recently started conducting more research than in the past, and so, anticipate presenting the results. Thus my answers in sec. 4. 
(217) This station remains committed to applied research projects that will improve management and we will do what we have do to see this type of work continue - but it is a struggle - you have to want it very much to make it happen. I understand why many give up - increasing a administrate burdens and restrictions drain your "on the ground efforts" and emotions. Section 2: I probably should not have answered this section since I have minimal involvement in actual research. But, I have initiated studies, found \$, students, partners for research. If I wasn't involved and committed many of these projects and others would not have happened. Section 3.2: 5\% actual research, I am a manager who strongly supports research. I seek funds, partnerships, students, etc. Refuge biologist and others do actual work. Station biologist, $\mathrm{ms} / \mathrm{PhD}$ students, coop. Research. Investigators do work requested.

(218) Renamed in current job, and continue to seek research opportunities to both improve decision making, and improve personal performance.

(235) I started with USFWS as a seasonal biological technician which included more research responsibilities than my current position does as an education specialist.

(240) The job does not require research but can be done. [name deleted]

\section{Type of research content in job}

$5 \%$ of comments from all respondents (13/250)

$22 \%$ of respondents commenting regarding respondent's background (13/59)

(2) My research was mainly in my last job with the USFS as a fisheries biologist. I have continued coordinating, conducting, and summarizing fish data in my present job in coordination with the USFS and other agencies.

(40) My current position involved primarily reviewing environmental assessments and environmental impact statements and other NEPA-related activities. I do not consider my review of these to be research. Even when called to produce a product such as a fish and wildlife coordination act report, these projects, with transfer funds, must all depend on research done by others, not conducting new research?

(89) The research that I'm involved is project monitoring for the partners for fish and wildlife program which is gaining in emphasis. However, very little research is done by the E.S. In Arizona.

(97) I am not comfortable that the survey accurately portrays what I or my counterparts do. We must be experts for our lead species, and as such direct research including preparation and review of proposals, review and interpretation of data, and scientific judgments. I (we) rarely am afforded the opportunity to conduct field investigations, though we must be on top of the literature. Frequently, research is just the beginning. Thereafter, we have to explain it and sell it to our many state and non-governmental partners.

(101) My current involvement with 'research' does not include field work; thus, my responses about 'research' covers not only field data-gathering, but data and related problem analysis (for example, computer-based analysis).

(130) I am including in my definition of research, bird monitoring, synthesis of data from various sources, and coordination (by way of technical assistance, granting, and prioritization) of various monitoring and research projects within the area in the u.s. And Mexico that my program works.

(157) The research I am involved in is environmental investigations required by regulatory agencies to comply with environmental laws necessary to protect human health and the resource (environment). This research is funded by funds requested from DOI, private companies, and the university. There are many chemicals in the environment causing negative impacts to the natural resources. Research is needed to provide managers with information to make informed decisions. Currently, decisions are made based on information qualified by many uncertainties.

(168) "Research"-type investigations I participate in are usually done in conjunction with preparing legal cases and therefore much of the results of the data gathering, analyses, etc., that are generated can not be readily published until all the legal aspects of each case are resolved either through settlement or litigation.

(183) Most of the "research" I do consists of aerial surveys to assess and monitor populations of waterbirds for management activities, such as supporting ES recovery plans, harvest regulations, ENV. Impact statements, permit requirements, etc. I also provide aerial survey and piloting expertise to other investigators and agencies.

(195) The only research I do is obtaining water level readings

(209) Job has remained the same within the past three years. The results of my research have been used to: compliance with federal regulations. 
(221) I am an easement enforcement officer so most of my research is for law enforcement cases.

(241) Currently, all of my "research" activity is endangered species monitoring as just part of my job. Therefore, some of the questions in the survey did not seem very applicable to my situation, mainly in regard to my position. My job is refuge management and I do not have a research emphasis. However, if research is needed I feel there is a good atmosphere for getting it done.

\section{Miscellaneous statements regarding respondent's background $2 \%$ of comments from all respondents $(6 / 250)$ $10 \%$ of respondents commenting regarding respondent's background (6/59)}

(24) I am not sure if this applies to the survey or not....I am currently a permanent full time employee not in a SCEP position and in my second year of graduate school. The managers at my station have not only encouraged but also allowed me to change my schedule to go to class and to conduct my thesis research on the refuge. My advisor at the university and the refuge have partnered for two grants which support research on the refuge. However, I do have to analyze data and write the thesis report on my own time. The refuge will benefit from the research conducted and the published articles while I benefit by furthering my education. This refuge has supported another past employee in this same manner. The results from that thesis project have changed the way we manage that species on the refuge today and are looked at neighboring refuges. If only other biologists were so lucky.

(54) The situation that I am in is completely different than most of the biologists in similar program responsibilities.

(62) I hope to complete my PhD within a year.

(73) My job description does not remotely describe the duties that I routinely perform on the job. I have two complementary master's degrees (4 years of graduate education), but this is counted by OPM as only 2 years of graduate education for the purposes of hiring or promotion. I think that this is a flawed practice since my 2 complementary degrees make me better qualified to perform my job then if I simply held a PhD in either field. Even this survey has a box titled "what is the highest educational degree that you have obtained" which implies that someone with a PhD is more qualified then someone with 2 interdisciplinary master's degrees.

(126) Some in my position would say I'm overqualified relative to others with similar duties, but I'm quite satisfied and feel my duties reflect my position well

(236) I am responsible for designing courses for the FWS addressing the use of science in decision making and conservation planning for endangered species. I am the design team leader and coordinate the efforts of scientists from several agencies \& universities. While not actively involved in research myself, I am acutely aware of the scientific skills required of FWS staff and encourage increased participation of USGS scientists in assisting/supporting FWS staff in practice and in providing training. I am very interested in results of your survey and hope it will be available to FWS staff soon.

Primary category: comments regarding research in the FWS

$52 \%$ of respondents' comments $(130 * / 250)$ contained content reflected in this category.

*several comments appear in two subcategories of this primary category, therefore the comments number 130 and not 139 .

Necessity of research in the FWS

$21 \%$ of comments from all respondents $(53 / 250)$

$41 \%$ of respondents commenting on research in FWS $(53 / 130)$

\section{Sub-theme: research should be internal to FWS}

(18) Fish and wildlife should be involved in more monitoring activities. USGS-BRD and best divisions are supposed to conduct monitoring on our behalf but this does not happen. We need to care for our research needs ourselves and not expect others to do them. Also, when we conduct studies, we gain from the experience and can use that work as opportunities for training our junior coworkers.

(39) Would like to see more research opportunities within FWS and prefer having a research branch within FWS.

(42) The FWS needs to upgrade their research because USGS is a not necessarily that receptive to our needs, and we have the capabilities to do the same work. 
(48) Thank you for asking from a long-term, seasonal employee. Desire is the project and not the pay check. Can't live in that unreal world much longer...student loans are not getting chunked out as a GS-7. Might be jumping ship to go work for USGS. Would rather stay with this agency and be part of the return of research within the FWS, to complement and collaborate with USGS, academia and non-profits. Cheers

(50) I feel it is critical to FWS success as lead agency with mandated fish and wildlife management and regulatory responsibilities to have clear vision on research needs specific to our agency mission. USGS and cooperators cannot fill role of research needs that require internal coordination and vision w/n FWS (e.g. Endangered species, ANS). A scientifically based management agency without a R\&D arm is left to accept new and evolving information w/n the context of political priorities, budgeting shortfalls, agency ownership issues which is not conducive to 'good science' or the scientific method.

(52) Encourage more research without jeopardizing our management responsibilities.

(57) FWS needs to rebuild it's research capability within the agency

(59) Make it mandatory to review the "science" in monitoring programs every three years or so, and provide adequate funding for an independent review panel. Get serious about publishing, and provide an incentive - promote staff that publishes. Provide opportunities to share "science" expertise between offices. Do something to attract and keep staff with good "science" capabilities, and remove those that don't. I spent 23 with NMFS before I came to FWS. I started my career with NMFS as a gs5 and left as a gs13. I advanced within NMFS because I developed and repeatedly demonstrated my research capabilities. I don't see that opportunity in FWS, at least at this office.

(60) I believe that data gathering through responsible research should be top priority for the FWS. The FWS cannot responsibly update the status of species or resources under our jurisdiction without appropriate data. Biologists should be directed and encouraged to coordinate, lead, and/or supervise research activities or research possibilities (e.g., partnerships, contracts, or grants) that would better assist the FWS in making properly-informed management and recovery decisions. Without the necessary tools and support, FWS biologists cannot provide the agency with the best available information to conserve and enhance fish and wildlife resources.

(61) FWS needs to a research career path.

(75) I have just started in a job that has more research potential, so most of the answers received in this survey are from two research projects conducted within my first 10 years in FWS. Hopefully opportunities to conduct research will increase. Unfortunately base funding is tight and appears to be getting tighter, and partner's money also seems to be disappearing.

(77) It would be terrific if the FWS would recognize that ecological services biologists could and should conduct research! It would also be terrific if FWS would be able to get the research they needed done through BRD, as it was supposed to happen. However, if you are a botanist and need plant genetics research conducted or specific life history research, there is almost zero chance of getting BRD to do it, either due to lack of interest or capability. Getting research accomplished on plants in the FWS is virtually impossible unless you go to an outside source for funding and investigators.

(80) The FWS needs to create a research branch again. The research needs of the FWS are not being met in an organized and efficient way.

(90) Move the research function related to USFWS back to USFWS!

(94) In the service we need to do proper science and base management decisions on data. Additionally, there are a number of ways to encourage our workforce to do more \&/or better research within the confines of existing positions.

(98) The FWS desperately needs a recognized research component. Short of bring the coop units and science centers back into the FWS, at least develop positions and opportunities to conduct research to address the needs of the FWS. There are a number of FWS employees that are capable of conducting high level research but they are frequently told not to do research as that is the role of BRD. Unfortunately, very little information needed by the FWS has come from BRD as most researchers within BRD are not interested in the type of research needed by the FWS. One suggestion is to develop partnerships between the FWS and universities by placing designated FWS researchers at universities to conduct research needed by the FWS.

(99) I came to the service after 17 years doing research and monitoring on the great lakes with us EPA. Would love to see more (actually any) career advancement paths for researchers. 
(100) The loss of FWS region 8 crippled FWS capabilities to scientifically track, monitor, and manage fish and wildlife resources. Only in a very few high profile cases are adequate resources available to do the job in house or through funding external groups. There is a widening gap between research and FWS as the proportion of FWS managers and staff with research backgrounds and knowledge shrinks. Research capable young people are unlikely to choose FWS careers when there is no research/monitoring mission available. Some may end up in FWS for various reasons, but not because of research opportunities. The disaster of losing region 8 has torn the heart and soul out of FWS.

(102) As oversight and review of our work continues to increases under things such as the data quality act, reporting requirements under ATAMS, tails and/or other workload tracking systems, and pressures from economic interests of any given us administration and/or local politicians, our work and decisions are going to be open to increasing scrutiny and challenges. In my opinion, research and management can not be separated without negative consequences. Research is a facet of scientific based management that validates a given management scheme, identifies existing inadequacies, or future needs. Without this type of oversight, management operates in a vacuum, under a static view of the world.

(107) Refuges have to find a balance that excludes "hobby research" but includes sound high-priority project that refuge biologists participate in (to maintain the refuge focus and to build experience and credibility of the staff). We need to partner with BRD and others to provide statistical advice and experts in other disciplines not available in refuges. Once priority research is identified, biologists need to see projects through to publication, even if in gray literature and be sure appropriate data are stored in a database. Refuges are ideal in many ways to contribute to broader geographic based monitoring and should look for opportunities to participate.

(110) Since creation of the biological research division in USGS, the USFWS has generally experienced a slow but steady net reduction in the proportion of programmatic funding dedicated to conducting applied research. This is compared to the period when the USFWS maintained a research branch. In lieu of an increased agency commitment to conducting research, the agency now does a better job of encouraging partnerships or competing for limited sources of funding outside of the agency. My specific program is probably an exception and we have experienced slow growth in conducting research programs with direct management applications, in part due to specific congressional appropriation language, and in part due to an unfulfilled need to generate answers to biological question of importance to management of species, habitat, and/or human activities effecting species or habitat. My sense is that no matter how much effort is made in partnering with USGS, the FWS will not achieve a desirable level of support for scientific research until the agency recreates or rededicates significant support for research, inventory, and applied studies. My general sense is that upper level administrators are focused on areas that directly effect their positions....administration, budget, policy development, etc and consequently until a priority is placed on developing research capacity to generate answers to pressing resource question, and a concomitant agency commitment to accountability for achieving these ends we will continue to overlook biological research. This is sad since these natural resources and an adequate understanding of life history, demographics, response to perturbations, etc. Are the underpinnings of our stewardship obligations? They are the core of our public trust obligations and they are the reason we receive public revenues. My suggestion would to recreate a research function within FWS or program specific research functions.

(112) Research should of stayed within FWS and not to USGS.

(142) The service should provide opportunities for career advancement (higher jobs grades, and supervisory responsibility) to those who choose to remain in "field" (research)-oriented positions. There is no "career track" for this sort of development within the agency.

(151) In today's rapidly changing environment, the service, now more than ever, needs in-house scientific investigations to help guide decision-makers and fish and wildlife managers. Scientific investigations do not have to be strictly "research" type endeavors that can be published in peer-reviewed journals but can be simple investigations that follow the scientific method and hold up to peer-reviewed scientific scrutiny. This will obviously require more funds and staff but if this nation is serious about conserving and protecting our dwindling fish and wildlife resources, it needs to make this commitment. Our stakeholders such as hunters, anglers, and wildlife watchers need to be made aware of this.

(155) Refuges should have their own scientific staff. It is very expensive to contract out scientific work to the USGS. We would accomplish very little scientific work at our refuge if we had to depend on hiring other people to do it. It would be better to spend money upgrading our existing biological staff through training and new hires than to spend money hiring people who are not familiar with the local conditions under which the work is to be carried out. It was a mistake years ago to take the biologists out of the refuges and put them in the NBS and now the USGS. It is time that we recognized this mistake and returned science to the refuges.

(166) Need to keep the good people around and give them permanent positions instead of letting them go. Once this happens, it takes tons of time and effort to train the next batch of folks that eventually leave because they realize there is no future. 
(171) I am very encouraged that you are doing this work. I spent the first 16 years of my FWS career doing applied fishery research in the fisheries assistance function, all in region 1. I have been out of that division now for 9 years. I really can't expect to do more research than I am now, in the job I have. I saw the service make a positive transition from being providers of recreation to being stewards of recovery. During that period, there was always a gap between our research branch and fisheries assistance. This was so both before and after the unfortunate transfer of that function to USGS. Our local fisheries office seemed to develop its own agenda independent of research. That was tolerable, for as long as we had stable base funding and lots of flexibility to take the initiative, we were able to do most of the applied research that tribes, states, and watershed councils needed, and the work was immensely satisfying. I think reduced funds have limited our applied research capability while much litigation has forced our agency toward a regulatory emphasis. Meanwhile, the states, tribes, and NOAA fisheries have stepped in to take over many of our former responsibilities. I don't think we can go back home again, but we still have a culture of creativity, initiative, and follow-through to the finished product. With top-down support, my opinion is that research could recover at least part of its former emphasis in our agency.

(175) I wish that FWS was more research oriented in nature, as we were pre-mid 1990s. As it stands now, I feel that we are generally just bureaucrats acting as consultants ever since our research branch was stripped from us (what I refer to as "Bobbitt's folly"). I firmly believe that this single action compromised the scientific integrity of our agency and I hope against hope that we will some day get our research folks back into FWS.

(178) I work as a plant ecologist in Alaska, because I love what I do. I think it is important for an ecologist to be committed to work in one region as their life's work. Experience and understanding are essential and are of great benefit to the service. However, I see little opportunity to increase in GS level as a practicing plant ecologist. There should be an avenue whereby an employee was valued and rewarded at higher GS levels for producing highly-credible scientific papers. This does not mean that I would leave the service for more money or become a manager. I love the work I do, but it is clear that managers are rewarded from the GS and financial aspect. This is not necessarily true for botanists that function as scientists.

(184) Bring independent science capacity back to the FWS!

(194) While my position requires almost no research I would hope that as a premier professional organization that the FWS would conduct research and publish research results.

(220) Move research staff from USGS back to FWS.

(239) My time would be better used on evaluations rather than interagency coordination. But the service does need somebody to do the coordination. It was a mistake to take FWS research people away form FWS and put them into USGS.

(247) As I supervise field stations who conduct research, I have answered questions for those stations. I have not performed research for $20+$ years. The service desperately needs a career track for scientists/researchers so we can retain their research skills. To get ahead, you must go into management with ABC, RPI and KPMG audits to name a few. We spend an increasing amount of management and staff time of administrative and not science or even policymaking that is a result of scientific endeavors. After looking at this, it is set up wrong. If a person checks the last item on page 2, "supervise or coordinate the efforts of there FWS employees...." They should go to track 2 and not track 1 . The web site has been down today (11/24/04). I reported it.

(248) FWS has had to increase research capability (internal) since our research arm transferred to USGS. USGS can be a valuable partner, but they are very slow (some times years) to release and share conclusions.

\section{Sub-theme: Necessity of research to fulfill mission of FWS}

(10) While it is tempting to focus exclusively on biological research, we also should be paying attention to social science research. For example, many management issues appear to be the result of crowding, but in fact are the result of lack of common mores regarding behavior in the back country.

(26) FWS needs more research done

(46) Lack of appropriate, applied research hurts our public image by forcing us to make and justify decisions based on gross generalizations, out-dated or out-of-context studies, or pure professional judgment. Such decisions may then appear unscientific. We cannot prevail in protecting public resources or conserving at-risk species without research results to back up our policies and decisions with solid data. 
(64) Few people who have done research choose to apply that depth of knowledge to decision-making or policy efforts. Most scientists shun policy and try to "keep their hands clean" and stick to just the research side. There seems to be a large gulf between the creation of the actual scientific product ("scientist") and the use and understanding of that product ("manager"). The scientist-manager gulf is huge! However, the translation of science into policy is a critical linkage for the FWS as a predominantly science using agency. The FWS must put some resources and strengthening this linkage. Thus, while I don't do research for the FWS I am actively trying to strengthen the linkage between science and policy/decision-making.

(78) I strongly believe that the FWS needs to make research and monitoring a higher priority. Our understanding of status and trends and the underlying causes of these trends, coupled with the need for an ecosystem approach to management argues, in my view, the need for increased and continued effort in this area.

(103) As an agency we need to take our research responsibilities seriously and not just pay lip service to the concept. This means taking on a leadership role in the monitoring and adaptive management of regional hips with multiple participating jurisdictions if we want them to be successful. While we attempt to do that here in this office, more resources need to be made available for plan implementation (and follow up on section 7 consultations) than are available currently. We need to be able to dedicate qualified staff to these activities, rather than filing the project away and hoping that it works.

(109) In general the service would do better science without the artificial dichotomy between "research" and "management". The programs need to be reviewed for relevance. Research should be question driven with actual research designs and should be aimed at understanding processes, rather than having a narrow focus. It should, at least in r7, be aimed at collecting baseline information and understanding.

(157) The research I am involved in is environmental investigations required by regulatory agencies to comply with environmental laws necessary to protect human health and the resource (environment). This research is funded by funds requested from DOI, private companies, and the university. There are many chemicals in the environment causing negative impacts to the natural resources. Research is needed to provide managers with information to make informed decisions. Currently, decisions are made based on information qualified by many uncertainties.

(176) I believe that the current system, with BRD separated from FWS and FWS supposed to be getting any science knowledge necessary to make management and policy decisions purely by osmosis from a distant source, is quite detrimental to the agency's effectiveness as a science-based management and policy agency. While I personally have no need to do a lot of research, I have been (until very recently) regularly discouraged from even attending scientific meetings much less undertaking research myself. When I have attended the society for conservation biology or other scientific meetings, I find the service very poorly represented, which cuts us off from some of our potentially most useful supporters and allies. The most regular staff I see at these meetings tend to be there on their own time and dime. Similarly, journals are difficult to access, and must be read on personal time. Thus, whether the result or the cause, the service's scientific knowledge often seems both parochial and outdated and I worry about the effectiveness of management decisions based on such.

(177) Personal considerations maintain me at my current location (husband is a tenured professor in the local university). Also, I worked in research positions for years before joining the service. I am looking for new challenges, but would like to focus on challenges for restoration of aquatic and coastal habitats through work with others. Academia has many researchers to play the publications game, but few that can afford (career-wise) to conduct long-term research and monitoring. The public perception is that government researchers are carrying out these longer-term, but lower publication yielding tasks. This is not true. The biggest fallacy is that these tasks might be relegated to graduate studentsdefinitely not true. Government researchers should be given the time and resources to dedicate to this longer term, albeit lower publication yielding and "sexy" research needs. We desperately need this information to understand where the resources have been, where they're going, and why. Pushing government researchers into high publication yielding pursuits will simply throw them into the same game as academic researchers. Government research obviously needs sound peer review to ensure good science, but should be done separately from the academic scramble.

(197) I enjoy doing research, but in the position I am in, I find that time is the biggest hurdle with respect to doing research. There is a great need to do specific research in stream restoration, and I would be happy to become more involved in supporting and supervising students, interns, etc., in research opportunities relating to stream restoration. A research fund that supported students and provided allowances for us to add in time and equipment to a project would be one idea.

(202) Although I do not do much research in my position with FWS, I use research to make regulatory decisions. Research is very important to my job and there is much information that is still lacking - for example we do not know what one of the federally endangered animals that I work with eats. Our own research staff (FWS biomonitors) and USGS staff (out of Kearney, Mesa and Carlsbad) have been extremely helpful to me. In particular, research staff was on extremelv valuable resource when I was working on the western riverside MSHEP In an addition USGS staff has helped 
our Carlsbad FWS biomonitors develop digital forms for data collection. This has allowed us to collect data on palm pilots and handheld computers, and download data into a database. This saves our biomonitors time and also helps to eliminate human error. The one problem that needs desperately to be addressed is that our FWS staff can not remotely transfer data to the USGS server. It is my understanding that there is some sort of firewall problem in Colorado. As a result, we must ask biologists that are heading in the direction of the USGS office to hand carry the data on CD. It is a great tragedy that in this day and age of advanced technology; the department of the interior cannot transfer digital data from one agency to another. Please provide USGS san Diego with support that they need to resolve this issue.

(203) Do not know and have never had research responsibilities. Although I am aware of budget and staffing constraints in FWS, it would be very helpful to have staff to do additional vegetation/habitat/wildlife monitoring in conjunction with refuge management activities.

(211) Pulling research from FWS was detrimental - development of NBS/BRD. FWS decisions are being overturned by interior bases on politics rather than good science. FWS needs more research to meet our obligation (e.g. SPP. Status reviews) - but needs the time specifically. Now we must collaborate with others to get research done, and are subject to uncertainties.

(226) As a grant specialist in federal assistance, I review and recommend approval of grant proposals that include research from state fish and wildlife agencies. Although some concern environmental education and its associated research, I also review grant proposals to conduct biological research. I rely on both professional conferences and journals and on my colleagues who keep up with the new research findings in their respective specialties. Important note: having professional federal assistance staff that know the science and keep up with the research is essential to: (1) our (FWS) ability to foster and approve the strongest, most effective research for the benefit of fish and wildlife resources across the country and (2) maintain our credibility, respect and peer relationship with our state agency and university colleagues. Losing that expertise would reduce the effectiveness of these grant programs that the congress has given to FWS to administer and would risk a deterioration of our federal-state relationships. Natural resources and citizens deserve the best science that we, collectively, can bring to the table.

(228) FWS does not appear to be able to meet most of its very basic research needs in the endangered species program. We look only to short term, small low \$ amount research projects. We can't even properly fund development of species survey protocols, never mind, original research. ESA implementation is ham strung because of the lack of information we have available and little chance of obtaining it through research. Regions work with chump change and don't even bother pursuing major research projects that are needed to unlock secrets of species that continue to decline. E.g. Indiana bats. For that species, declining $20 \%$ every 10 years, we still don't have even basic population structure of dynamic research. We may be just documenting its extinction, but don't even know it.

(231) I have many questions I would like answered regarding that habitat that I manage and restore etc. I would like to think that I am doing what's best for the resources that occur in my ecological regions, but often I am guessing at the results. More research could improve techniques that use, or completely change the way I do them - which would ultimately benefit the resources that I seek to improve. I may be making too many "educated guesses" and may have no idea if I'm improving habitat, or having little effect on the habitat I manage and restore.

(232) I feel more research could be done on refuges by refuge staff. Refuges tend to disregard done by university folks.

\section{Resources for research in the FWS \\ $18 \%$ of comments from all respondents (46/250) \\ $35 \%$ of respondents commenting on research in FWS (46/130)}

\section{Sub-theme: Funding/staffing issues}

(4) I didn't feel the questions really applied to me so I wanted to explain my own thoughts about the role of research in the FWS. Before I joined FWS I was in a research position. My first supervisor made it clear that my job did not include research and he was right and that continues to be the case today. The USGS does a great job of meeting our research needs when they have the staff and funding to do so. However, the FWS research needs far outstrip USGS' ability to do all needed studies. Consequently I believe the real research problem in the FWS is that we lack the $\$$ to fund needed studies. One could; however, make the case that without the budget to fund studies we should be doing more of them ourselves and I believe that is true. However, in ecological services there is too few staff to meet our ESA and contaminant responsibilities much less to do the needed studies. Management may feel that research is a low priority because they lack the staff to do the required work for which we have funding. Therefore, I don't believe it's as much a problem with management not giving research a higher priority as it is a problem of congress' failure to adequately fund USGS and FWS. 
(16) I think that biological programs on refuges should have a separate funding subactivity that cannot be redistributed to other accounts. A set $\%$ of the base should automatically be allocated to this subactivity. This would allow better tracking of the services commitment to science and remove the discretion of managers to fund biological research and monitoring. I also believe that any new projects initiated on the refuge whether they be public use, fire, or habitat management should automatically include an assessment charge for monitoring that will be distributed to the biological program subactivity. Remaining biological funds should also be rolled over each year to allow for project continuity.

(41) Your wording in the section on support does not ask the fundamental questions - yes, I have access to refuge tools, computers, and all my higher ups say "yes, do research!", but we need cash and staffing to carry out research and we have neither. Can one biologist with no budget (some stations don't even have one biologist) carry out the necessary research for a large refuge complex? No, so we all feel totally burned out. If the service wants to truly promote scientific excellence, it needs to put its money where its mouth is! The good science that I do get done is usually in spite of the efforts of the service to have me do otherwise. You ask where I can partner to get the financial resources to run my program-that's unrealistic. Yes, I partner like crazy all the time, but that is still not satisfactory-it isn't working. To be effective I need some kind of very basic budget to start with, that I can depend on more than soft money with strings attached. Do you ask refuge managers who they partner with to get their operating budget? Of course not, because they have to start with some kind of basic budget to function (and then we all can partner later). Our maintenance staff gets a very nice well-funded budget, so I often beg from them to try and augment my program, but it requires bending the rules so really isn't right-I feel bad doing it, and shouldn't have to!

(53) Research is not important or emphasized by the RO. Participation in professional societies and symposia is not encouraged or supported. IDPS are left unsigned/unapproved and in some cases been used as an excuse not to permit attendance/participation a professional conferences because they are not signed. It is critical and essential for those of us in natural resource management and research to stay in touch with our respective fields and all the information that is being generated today. I find the service ultra conservative in its attitude and philosophy towards research and professional society participation of its employees. This lack of participation hurts the agency and it hurts the employee as well insofar as maintaining career/professional proficiency. Despite the encouragement given in the "town meeting" broadcast last may about the desire to have more FWS employees participate in professional societies, it isn't getting done. A recent example of lack of support - a request for one day leave (the conf. Was held over a weekend, Friday through Monday, so only one work day was required) to participate in the society for conservation biology conference in New York in aug.'04. Rejected. A request for leave/support to rep the service (personal invitation to participate) as a delegate to the congress on building capacity for coastal solutions, wash. Dc was rejected. Although we have some 165 NWR in the coastal/ocean/estuarine environments, anything with coastal or marine in the title is considered "not job related." People who serve as officers or on the board of directors of professional organizations are not being accorded official leave and travel to participate. Of course some others in programs other than refuges are granted time/official leave/travel funding. Equity is not equal and managers/supervisors make up their own policies to support their own decisions.

(56) Research is needed, but we need to get our house in order. Adequate funding needs to be obtained for core activities before funding is spent on research activities. If core funding is not obtained how can a non-core activity like research even be considered? The research needs to be linked to a core activity so something useful could possibly come out of it. If the research doesn't help anyway with the service's activities why should we sponsor it and use our limited resources to fund it? Mandating research is wrong, good useful research should develop from a need not a desire or whim.

(72) As an agency we chronically have too few dollars chasing too many projects on nearly 100 million acres of FWS lands. I have come to recognize that we also have an identity problem when viewed by the public because our mission has long been obscured by poor public relations and a lack of status as a stand alone, land based natural resource management agency. Rather than being recognized as a national wildlife refuge system, we are a cog in the wheel of the u.s. fish and wildlife service along with a variety of other entities with many related, but different missions. This dilutes the annual funding even more. The end result is that the resource, i.e. Refuges, never get enough money to maintain what we already have much less advance through research. With fewer branches squabbling over funding perhaps we could develop a meaningful research arm.

(74) We need a uniform policy that supports peer-reviewed publication of research as the norm. At the moment I need to get independent funding to support my salary during write-up because "publication is not a priority". This causes research funded to support management to languish in the gray literature and professional credibility to erode.

(105) Increased base funding would be nice, but I am sure everyone says that!

(108) have only been with FWS since June 1, came from USGS. Conducted research only at USGS, but was impressed by research opportunities with FWS. Was disappointed to find that no budget/personnel were available for research in FWS. Not likely to leave this job within 6 months, but may start looking. 
(116) Reduction in research responsibilities is in part due to reduction in budgets and staff. It is also impacted because of time constraints due to increased information requests, surveys, administrative workload and picking up the slack for others.

(118) I have just started a new position and have not fully explored research possibilities within this position. One thing that I found frustrating in my past position was the rush to get a nationwide survey implemented, which lacked field sample oriented quality assurance/quality control (QA/QC) standard operating procedure and, in my opinion, was not properly funded/staffed for the amount of intense field work required. As a result, surveys had to be rushed and implemented before the protocol was finalized so that protocol timelines could be met; common species, which were similar to the target species and would have been expected to be present each year, were not detected each year; there was no QA/QC on formulations sent to the field, which may have been of variable strengths due to mixing problems/errors, and may be the reason common species were not detected in some years; as well as a variety of other problems causing undesirable working conditions. There was also a perception that principle investigators and other decision making personnel had preconceived ideas on where the species existed based on certain criteria while other criteria appeared to be ignored, regardless of the evidence to the contrary. I believe all of these problems could have been avoided/fixed if the surveys would have been delayed until fully developed (I. E., implementation would have had to be delayed by one year), principle investigators and other decision makers were more receptive and had better field review/personnel interaction, the surveys were properly funded/staffed, and QA/QC procedures commonly used (such as contaminants studies) were developed/implemented for field samples collected in association with the surveys.

(137) I have not had the opportunity to attend FWS seminars providing information about funding sources for research.

(145) Within the past five years, I have written 4 biological research proposals to address wildlife management issues but have not received funding to conduct the research.

(172) Our biggest obstacles to conducting meaningful research:

1. Money

2. Staffing

3. Perception that research is not for FWS to do

(182) In addition to needing more time and financial resources to conduct research (who doesn't?), additional educational opportunities to remain current or obtain advanced degrees more aligned with increasing research complexity could be beneficial. Thank you for conducting this survey and providing the opportunity to respond. The results will be most interesting.

(223) The questions in this survey do not apply to my position. I supervise biologists, fire staff, foresters, and public use employees that may be involved in research activities. These questions seemed designed for them. However, no funding is available for research and limited staff makes research a very low priority.

(228) FWS does not appear to be able to meet most of its very basic research needs in the endangered species program. We look only to short term, small low \$ amount research projects. We can't even properly fund development of species survey protocols, never mind, original research. ESA implementation is ham strung because of the lack of information we have available and little chance of obtaining it through research. Regions work with chump change and don't even bother pursuing major research projects that are needed to unlock secrets of species that continue to decline. E.g. Indiana bats. For that species, declining $20 \%$ every 10 years, we still don't have even basic population structure of dynamic research. We may be just documenting its extinction, but don't even know it.

(229) As stated: I don't have an adequate station budget to hire a full staff. Therefore, we don't conduct research because we don't have staff to do the work. Our current staffing level only allows us enough to complete work that is essential to operations. Feed fish, clean ponds, fix equipment.

\section{Sub-theme: Conflicting responsibilities}

(1) Via our responsibility to protect our trust resources and fulfill our agency mission, quality control of mitigation should be an important role for the FWS. As it stands it plays a relatively minor role compared to our other job responsibilities. We need to find ways to balance this currently skewed situation.

(63) We would like a stronger relationship with the researchers at USGS so we can have them as a resource for assistance in data analysis. Better training in analysis methods for ourselves. Basic training of supervisors so that they understand that they are tasking some of their staff to develop recovery plans/activities, or develop/review monitoring plans for HEPS who have little understanding of how to do this. This wastes resources on poorly designed activities. 
(69) Lack of manpower on many stations has biologists often doing management work, just to make sure it is done when needed. Sort of a mixed blessing and a curse to people interested in management aspects.

(76) The amount of paperwork has increased dramatically in the six years that I have been a service employee. On most refuges, management staff does not have the resources to do their office work. Thus, some of it filters down to biologists. If this trend continues, along with inadequate resources to perform the necessary biological work, natural resources on refuges will suffer. Although not directly related to research, the FWS needs to get involved in land use planning so refuges and similar federal properties will not end up the only reservoirs of biological diversity. Perhaps this should be coordinated with other agencies to get the attention of the congress and garner support for consideration of natural resources in land use planning. Definitely an uphill battle, but one that should begin now. I have seen this effort pay off big dividends in a program I worked for in the Chesapeake Bay area. The benefits of our private lands initiatives will disappear as development gulps up land in an uncontrolled manner. Getting involved in land use planning will conserve more "trust resources" than we can ever do on our relatively small land base.

(84) Different supervisors have approached research differently, both fiscally and in terms of job time allocations. My opinion of research needs is sometimes very different from my supervisor's

(147) If I am too strongly encouraged to conduct scientific research, publish and present papers, instead of focusing on improving management and natural resources of our refuge (the two are not mutually inclusive), I will probably look for another position inside or out of the FWS. I probably do not possess the necessary skills, and certainly not the time to conduct scientific research (I do conduct research, but typically without randomization and without statistical analysis). I do not now have the time to read and assimilate applicable research documents and information that would allow a better understanding and management of refuge resources. Other research entities do conduct scientific research on the refuge, and which aids in management decisions.

(152) The real problem is too few people and resources to do all the jobs managers dream of. Management needs to learn how to prioritize, and to scale project goals to realistic levels so that people can do quality work. The current situation places superhuman expectations on the people that actually do the work. Consequently, creative, dedicated people are likely to look for a job somewhere else, before their careers are destroyed in a situation where they cannot win. The focus needs to be on quality, not quantity. This has never been the case in my experience here.

(179) Administrative and reporting burden of project leaders and staff have increased greatly in recent years, with resultant decline in time available for research, monitoring, and evaluation. Base funding decreases have lead to increased vacancies and loss of expertise and research capability.

(181) Sorry if my answers seemed offensive, it's the frustration talking. We're sucking wind out here in the field and while administrative and reporting requirements (and surveys such as this!) continue to pile up, we're losing staff and money. The resource will suffer and no one seems to be paying attention.

(249) Report writing work load is precluding $90 \%$ of needed basic and applied research on our refuge resources. Monthly activity reports, annual narratives, rear, laps, annual habitat work plans, etc. We are crushed by our paperwork load. We can't even complete fundamental monitoring of endangered species much less design and implement studies to improve habitat management.

\section{Sub-theme: Working with other agencies}

(27) I think there is a significant need to get USGS researchers to work more closely with FWS biologists on applied, product oriented questions. There needs to be more support within USGS for those researchers who work closely with stakeholders on the application of their research results. This is a form of scientific productivity that doesn't appear to be supported within USGS but is the link that is needed to insure that scientific results are applied.

(63) We would like a stronger relationship with the researchers at USGS so we can have them as a resource for assistance in data analysis. Better training in analysis methods for ourselves. Basic training of supervisors so that they understand that they are tasking some of their staff to develop recovery plans/activities, or develop/review monitoring plans for HEPS who have little understanding of how to do this. This wastes resources on poorly designed activities.

(77) It would be terrific if the FWS would recognize that ecological services biologists could and should conduct research! It would also be terrific if FWS would be able to get the research they needed done through BRD, as it was supposed to happen. However, if you are a botanist and need plant genetics research conducted or specific life history research, there is almost zero chance of getting BRD to do it, either due to lack of interest or capability. Getting research accomplished on plants in the FWS is virtually impossible unless you go to an outside source for funding and investigators. 
(86) I worked with the USGS as a researcher before coming to the FWS, and further back, with the FWS before the research wing was split off into the USGS. Currently, I rely heavily on the USGS to provide research I use when writing recovery plans and regulatory documents. Whether it was better to have had research as a branch of FWS, or that the current arrangement is more appropriate, I don't think I can comment on. However, the connection between FWS-ES (regulatory) and USGS (research) is essential to my doing my job well. At least within my current job description (and the general job responsibilities of ES as I see these), without that connection to research, and ideally, targeted applied research that informs management decisions, it would be extremely difficult for me to do my job. I guess this is sort of a statement of the importance for a continued close coordination between FWS and USGS to support and develop good research for species conservation.

(92) Splitting the research unit of the USFWS off was probably not one of the smartest things to have happened. Since that time I have seen a change in the way the service operates. Our office went from 100 to $50 \%$ assistance to state and public needs and now the other $50 \%$ is more in the way of research, applying for grants, writing up reports and presenting the findings. This is not a bad thing, as I am enjoying the change in conducting more research. I have noticed now that when job openings are available, they tend to lean toward applicants with their PhD's, though they may not be the best suited. This is done to get more people in that have the mentality for conducting research. This change has also led to competition between USGS-BRD and USFWS for the few funding sources that are available. Instead of working together most of the time, the two agencies are competing.

(167) There needs to be closer coordination between the USGS research stations and the ecological services field offices so that coordinated research can occur. The local USGS office does little research that addresses ecological service's needs and questions. The USFWS should re-emphasize research as a means for answering basic questions about species recovery and management, rather than continue to be stuck in short term thinking and producing rules without any overall advances in our knowledge of species' biology.

(189) An earlier question mentioned publications of the FWS. I think that is a great idea, but such outlets need credibility. Publication in one FWS publication with which I am familiar is dependent on the whims of a poorly qualified nonscientist editor whose name often ends up added to the list of authors. People in the field are aware of this, and science and the service are served poorly by such actions. Adopting an editorial board, similar to that used by most scientific publications, would be appropriate and would help restore credibility to service publications. However, this board should be comprised of qualified people from throughout the region, not a small group of cronies from within the regional office. Also, we have been told many times by our regional leaders that research for the service is the purview of USGS. That does nothing to promote good science within the service, and also ignores the fact that many researchers within the USGS whom we have worked with won't touch a project without lots of money and guarantees of first authorship on resulting publications.

(202) Although I do not do much research in my position with FWS, I use research to make regulatory decisions. Research is very important to my job and there is much information that is still lacking - for example we do not know what one of the federally endangered animals that I work with eats. Our own research staff (FWS biomonitors) and USGS staff (out of Kearney Mesa and Carlsbad) have been extremely helpful to me. In particular, research staff was on extremely valuable resource when I was working on the western riverside MSHEP. In an addition, USGS staff has helped our Carlsbad FWS biomonitors develop digital forms for data collection. This has allowed us to collect data on palm pilots and handheld computers, and download data into a database. This saves our biomonitors time and also helps to eliminate human error. The one problem that needs desperately to be addressed is that our FWS staff can not remotely transfer data to the USGS server. It is my understanding that there is some sort of firewall problem in Colorado. As a result, we must ask biologists that are heading in the direction of the USGS office to hand carry the data on CD. It is a great tragedy that in this day and age of advanced technology; the department of the interior cannot transfer digital data from one agency to another. Please provide USGS san Diego with support that they need to resolve this issue.

(219) I think the USGS could be used as a resource by the FWS, except the structure does not encourage partnership. The funding is not shared, but competed for. This causes strife instead of collaboration. Money set aside by our agency to be paid to USGS for services would solve this problem.

(248) FWS has had to increase research capability (internal) since our research arm transferred to USGS. USGS can be a valuable partner, but they are very slow (some times years) to release and share conclusions.

\section{Sub-theme: Other resources}

(6) I find that too much emphasis is placed on what degrees a person has. Too often the belief is that one is incapable of doing research or can not do quality research unless they have a PhD. After their name. The FWS has a lot of incredibly talented field biologists who are more than capable of doing the research needed if they were only given the resources. 
(8) Technological support for research is non-existent. It, throughout the FWS, has been either of no help or acted as an impediment to our efforts in collaborating with USGS and other partners, as well as in our efforts to deploy technological solutions to data collection efforts. For example, use of PDAS to collect field data is completely unsupported, despite their ability to significantly reduce labor costs and improve data QA/QC. USGS is able to offer limited support, but FWS network protocols prevent data sharing with USGS partners (an IT issue). Recognition and support of technology that can provide solutions to common problems as well as establishing open standards that permit or even promote data sharing and collaborative research between agencies would significantly increase the efficiency and effectiveness of the research at FWS, USGS, and other partnering agencies.

(35) Thanks for getting us access to the electronic journals in the recent past. This has been a tremendous time saver. Please increase the number of journals in the pollution, toxicology and medical journal areas.

(68) The service's online literature search capability/interface is excellent and should be retained. The electronic library of journals available online is a good start, but should be enhanced. In this age of needing information at your finger-tips, it is vital to be able to get this kind of information without having to drive across town to a research library and photocopy journal articles. There are several contaminants journals like environmental science and technology, marine pollution bulletin, etc. That the service should subscribe to.

(115) I have only been a biologist for the last year, in that time good research support.

(128) Research support in FWS for service scientists is completely missing in this organization. There is no recognition of the necessary research work some of us do nor the effort does it take to get outside the service funding to accomplish this necessary work. Why this is a mystery.

(190) Would appreciate receiving a copy of survey results. Hopefully these promote some change in the institution. One other point: it would be useful if the service could establish a more effective institutional (and funding) framework for science support. Prime example of an effective top-down initiative is the national park service's natural resource inventory and monitoring program.

(193) Please make a recommendation for an agency-sponsored web-based journal that would become the service's or refuge division's outlet for archiving and sharing gray literature. This is a major gap and problem within the service. Too few of our reports ever make it to a peer-reviewed journal. Most refuge workers recognize that the results of all their projects may not merit publication in a journal, but such reports certainly merit better archiving and sharing within the agency.

(241) Currently, all of my "research" activity is endangered species monitoring as just part of my job. Therefore, some of the questions in the survey did not seem very applicable to my situation, mainly in regard to my position. My job is refuge management and I do not have a research emphasis. However, if research is needed I feel there is a good atmosphere for getting it done.

\section{Outside influences on research in the FWS $6 \%$ of comments from all respondents $(15 / 250)$ $12 \%$ of respondents commenting on research in FWS (15/130)}

(5) The service isn't held in very high regard w/our peers in other fed. agencies, state agencies, private sector, or academia. We aren't as lowly as bureau of reclamation or corps. of engineers, but we aren't much higher up from the bottom of the pile. The staff biologists constantly get rolled by the very top heavy layer of middle management at the state fish \& wildlife offices, and especially at the regional offices and D.C. Politics plays way too much of a role in our agencies decisions and in funding from D.C hiring practices weigh heavily on nepotism and cronyism and most offices are very incestuous. The managers at every level are populated by climbers who show up to work to work on their next promotion, not working to recover listed species and their habitats. Moral isn't that high, and there's not much respect for the managers. This isn't meant to be a rant, just the way I see it. Maybe I'm an ideologue, or full of it. Working for a bureaucracy is tough, and I am not naive to think there is any "big” organization that doesn't basically exist to self perpetuate and not reach the goals of their mission statement or what society (and taxpayers) expect of them. Enough said.

(7) I hope that this survey can reveal that the role of research and science in decision-making at the FWS and DOI has been severely undermined. It is not only the lack of original research, but the notion that data can be rejected (or worse, it is "bad science") if it does not fit into the goals of the decision makers. We have numerous instances where peer-reviewed literature was rejected or reinterpreted to support a position contrary to the conservation mission of the FWS. This has occurred even to the point of a reviewer inserting disparaging remarks about a researcher for no other reason than the researcher had data about the needs of a particular species that would have refuted a pre-determined conclusion. As a scientist, the politicization of science is extremely disturbing, and I object to a non-scientist defining "bad science" for me. 
(13) The service has a long tradition of excellent science that continues to the present day. However, the questioning of our science due to a political agenda is very disconcerting for all involved. To add to staff's frustration is the perception that BRD should do research which leaves the perception that the service does "hobby science" (see previous comments). As a side note, I know that refuges "is" the service, but as a non-refuge employee, it is very disturbing to see the blue goose side by side with the service logo as if refuges was an equal partner (as another agency would be) with the service instead of a program within the service. Signs/symptoms such as this add to the disillusionment/confusion as to how do non-refuge programs fit within the service and reduce camaraderie among programs that used to be within the service. Thanks for the opportunity to comment. I look forward to seeing the results.

(22) As a scientist it is extremely disappointing to be ask to complete this FWS "science" questionnaire without being given any meaningful background on the why, what, how and so what of the survey. Especially when my trust and respect level for how data and science are currently used, ignored, spun or abused is by far the lowest I've experienced in 33 years of federal conservation science service in both republican and democratic administrations.

(50) I feel it is critical to FWS success as lead agency with mandated fish and wildlife management and regulatory responsibilities to have clear vision on research needs specific to our agency mission. USGS and cooperators cannot fill role of research needs that require internal coordination and vision w/n FWS (e.g. Endangered species, ANS). A scientifically based management agency without a R\&D arm is left to accept new and evolving information w/n the context of political priorities, budgeting shortfalls, agency ownership issues which is not conducive to 'good science' or the scientific method.

(51) Once again, regulatory duties consume most of the staff time and it is prioritized as such. Although there is some support from administrators to advance science, often research is not supported if there is a chance for results to not support a policy decision. We often receive short notice for research funding but we are not able to utilize such funds because time was not prioritized for proposal writing. My last and strongest point of emphasis is that one's background in research and publishing is not at all considered when evaluating candidates for an open position. Most promotions/hires occur when applicants excel in law and policy but only meet the minimum education requirements (BS degree with minimum credit hours).

(71) What about the fact that our research information, applications, and recommendations are completely ignored by the Washington office? Policies are instituted based on political influence, not biological facts.

(96) I feel that science or research should drive what the FWS does and way to often it is neglected or pushed aside.

(102) As oversight and review of our work continues to increase under things such as the data quality act, reporting requirements under atoms, tails and/or other workload tracking systems, and pressures from economic interests of any given us administration and/or local politicians, our work and decisions are going to be open to increasing scrutiny and challenges. In my opinion, research and management can not be separated without negative consequences. Research is a facet of scientific based management that validates a given management scheme, identifies existing inadequacies, or future needs. Without this type of oversight, management operates in a vacuum, under a static view of the world.

(127) FWS administrators have become advocates of not offending outside interests to the point of not supporting individual biologists that have research findings that become contentious. As part of that advocacy, FWS administrators will 'throw to the wolves' any employee that doesn't toe the line and say what the 'official' word is. The sad fact is that the "good science" policy for DOI employees doesn't apply to management. FWS management is the worst enemy of the agency biologists.

(165) FWS management at the highest levels in the CNO is absolutely shameless when it comes to ignoring research in order to issue incidental take permits under section 10, to the point where the entire program is an embarrassment.

(170) This agency is moving toward a wildlife conservation schedule that is dictated by politics, not science. It is very disappointing and disheartening!

(185) There are continuing morale problems regarding research in FWS. The recent effort to instruct us in good science (video, etc.) was condescending, especially in light of the current hypocrisy on a larger scale of the lack of acceptance of global warming, the recent marbled murrelet decision, among many other decisions or positions that are contrary to good science. It is a discouraging atmosphere; however, I think field staff will continue to use integrity and science principles in decision making and resource protection and management to the best of their abilities and authorities. The loss of the research arm of FWS reduced our abilities to have good research available to problem solve. Coordination and communication with USGS has not sufficiently filled that gap.

(198) While most of my responsibilities during the past six years have been to compile and analyze data collected by others (production of biological opinions, EIS); I also have participated in research conducted principally by others in this nffice I now have inherited those responsibilities (due to retirement and other staff departures) with no reduction in my 
other duties. I feel quality research is crucial to the service meeting its management goals and obligations, but staffing and monetary constraints limit the production of useful information.

Although this may not be specifically pertinent to your survey, it has been my experience (especially during recent years) that politics, more than science, drives management decisions in the service. For biologists at mid-management levels and below, this is very disheartening.

(211) Pulling research from FWS was detrimental - development of NBS/BRD. FWS decisions are being overturned by interior bases on politics rather than good science. FWS needs more research to meet our obligation (e.g. SPP. Status reviews) - but needs the time specifically. Now we must collaborate with others to get research done, and are subject to uncertainties.

\section{Perceptions of the FWS as a research agency $10 \%$ of comments from all respondents $(24 / 250)$ $18 \%$ of respondents commenting on research in FWS (24/130)}

(31) Research in the service is not promoted, we lost that when we lost the research centers like Patuxent, Lee Town, and the coop units, what we do now are "studies".

(36) Any research in the service should be directed to on the ground accomplishment. "Good science" is important, but the definition of "good science" needs to be clear. Decisions should be based on the best scientific information possible. But, "good science" is directly proportional to the amount of time, money, and people available. There probably will never be enough time and money to know all the answers. To successfully protect and manage this country's fish and wildlife resources, timely decisions will have to be made with available information. In this day of ever increasing time spent on the policy and procedure overload, we need to be careful that requirements for producing peer reviewed articles in professional journals do not take precedence over on the ground accomplishments for fish and wildlife resources.

(37) In region 5, the regional biologists contracted with a statistician to answer any questions refuge biologist may have with their projects. I think this tends to be the weakest area for most biologists, and have helped significantly to improve research design and data analysis.

(87) This survey is more applicable for wildlife biologist than refuge managers. In addition, we were told years ago that biologist on refuges should not be doing research unless it was in cooperation with USGS or with universities taking the lead. Refuge biologists are supposed to collect data only on monitoring type studies that are not considered research. Perhaps this policy changed without my knowledge but that is the way I understood it as an employee with FWS.

(88) I find it mildly humorous/odd/something that we are being asked about FWS research in light of our researchers being moved to USGS. I just don't consider FWS to be a researching organization - at least not the ecological services portion of our agency. Because anyone with any knowledge at all of region 1 could figure out from my demographic info that I am, here it is: [name deleted]. So, if you have any questions about my responses, give me a yell.

(95) FWS needs to decide what level of research they want to be involved in and then to commit to it. It seems that ever since the research branch moved to USGS, the service has been unclear on what they should or should not be doing in the area of research. I can remember being told not to use the word "research" to describe any of my activities.

(113) I am one of very few experienced scientists in my office. I frequently am called upon to assist my co-workers with scientific issues, but I rarely am able to obtain assistance within the office on scientific matters because there are so few people with sufficient knowledge. I do not feel that I am part of an organization that conducts scientific research.

(119) Overall, I have a high opinion of the FWS, in spite of its many shortcomings. FWS could be a much more efficient $\&$ effective wildlife conservation agency. However, during my 25 year career, the agency has become more bureaucratic at the field level. When I first started working for the agency in the late 1970s, field biologists were more insulated from administrative \& bureaucratic tasks. We practiced good science and left politics to supervisors \& administrative tasks to administrators. Sadly, that isn't the case anymore. We're encouraged by FWS to practice good science (incl. Research where appropriate) but field biologists are so burden with bureaucratic BS (and given tasks that are unrelated to our jobs) it's increasingly difficult to perform good science. It's frustrating and tough on morale.

(140) Most positions in the service are not oriented towards research. In general, we provide oversight of program funding, review of actions, and evaluate impacts.

(162) The separation of the research branch within us fish \& wildlife service to that of us geological survey, has fragmented the research capabilities of the agency. In addition, there is absolutely no incentive or reward system in place to recognize those who publish peer-reviewed scientific research; or performance/conduct system in place to address 
biologist with no interest/skills to publish their studies. There are only limited opportunities to present at national meetings of wildlife professionals (e.g. The wildlife society). The agency limits how many staff may attend from each region, which is a disincentive to submit papers/posters for participation because of the uncertainty of funding to support presenting it. A travel ceiling in 2004 prevented me from presenting a paper at the Burlington, VT TWS meeting for which I had been accepted as a presenter. This aspect is very unfortunate. The TWS national meetings are comprised of professors and students primarily, and to a much lesser degree, state and federal agency personnel. Existing state and federal staff has much to contribute, but because of agency priorities, few are interested and willing to attend and contribute to the advancement of science. There is no incentives or reward systems by our agency to attend scientific meetings or to formally write-up results of investigations. This facet of the profession is left up entirely to the priority systems established by each individual employee. Those who believe it is important to present and publish the results of our studies do, without reward/regret; and those that couldn't care less don't. We both get paid the same.

(172) Our biggest obstacles to conducting meaningful research:

1. Money

2. Staffing

3. Perception that research is not for FWS to do

(204) Beyond my current "research " which is part of a large monitoring effort, opportunities or encouragement to pursue original research are extremely limited, at best. I have been told more than once that "FWS does not do research," since FWS research functions were split off to USGS-BRD (=NBS, etc.)

(205) Just reorganized and was re-assigned branch chief for "applied science" (fewer responsibilities for research in this capacity). Other comments: I am a lead in monitoring an endangered species (population trends \& habitat modeling) some do not consider monitoring as research per se. For the purposes of this survey, I am considering statistically valid monitoring as research. From my perspective, the FWS has lost the capacity to do scientifically credible research since it lost its research branch. Sure there are a few isolated individuals or groups who are involved with research activities, but generally speaking FWS does not do research (i.e. Hypotheses testing). There is shoe string work going on willy-nilly that those who are doing thing they are doing research, but in reality they are doing descriptive studies, or their work lacks a statistically valid/rigorous design (i.e. Most is not publishable). Lee, you are more than welcome to give me a call if you want to discuss the survey further. [name deleted] ( $p$.s. well organized and thoughtful survey!) Just reorganized and was re-assigned branch chief for "applied science." Fewer responsibilities for research in this capacity.

(213) When I asked four other employees if they were filling out this survey, they laughed at me and said "research in FWS is a joke," and "why bother - they will just add a little spin control and it will all mean nothing because "everything is fine"', If you complain, you get passed over for advancement. FWS is amassing a large bobble-head collection of biologists under the current regime.

(214) I have seen a steady reduction in emphasis on quality research in the FWS over the last 25 years (experienced both in the service and as a professional researcher before joining). I see contracting out our research capacity and directing our biologists out of the field and into paperwork administration as a major weakness. Refuge biologists must be out in the field to do their jobs well for several reasons. (1) They provide a better balanced view of the refuge ecosystem that cans contractors or specialists who are brought in for a short, narrowly focused job. (2) if refuge biologist are allowed time to go out in the field regularly on research, they will be in a position to notice small interactions that may well be critical but not noticeable on the short term or if you cannot go right out in the response to reports or conditions. (3) Refuge biologists will have the refuges best interests in view - not the "publish or perish" attitude that I have personally seen drive academic (and increasingly USGS) into making their personal, short-term job evaluations look good. There is a chronic problem with FWS biologists not staying in one location long enough to develop a consistent data base for the refuge since there is no career or salary ladder to reward them unless they move on. This may work for managers, but is a poor model for biologists. P.s. whatever happened to the promises that have been repeatedly reaffirmed both within and outside the service - that the top priority is a biologist on every refuge? We still have only $1 / 2$ the refuges with biological staff.

(216) I believe there are people in the USFWS that have been here to long and don't want to do anymore than they have to. They hold back others who want to do more. It is like they are afraid someone will gain more knowledge than them. I feel these types of employees see it as a threat to their job security if they give someone a chance to gain knowledge. 
(217) This station remains committed to applied research projects that will improve management and we will do what we have do to see this type of work continue - but it is a struggle - you have to want it very much to make it happen. I understand why many give up - increasing a administrate burdens and restrictions drain your "on the ground efforts" and emotions. Section 2: I probably should not have answered this section since I have minimal involvement in actual research. But, I have initiated studies, found \$, students, partners for research. If I wasn't involved and committed many of these projects and others would not have happened. Section 3.2: 5\% actual research, I am a manager who strongly supports research. I seek funds, partnerships, students, etc. Refuge biologist and others do actual work. Station biologist, $\mathrm{ms} / \mathrm{PhD}$ students, coop. Research. Investigators do work requested.

(227) I'm very dismayed by the apparent emphasis on bean counting and budgets in FWS as opposed to a focus on science and natural resources.

(238) Service needs to recognize its employees more when research is done and published in peer reviewed journals etc. Currently (my case) never recognized for any publications - however, have been recognized for promoting research projects.

(242) The key here is the fundamental difference between pure and applied science. Since Petuxent, Northern Prairie, and Denver have been spun off to USGS and USDA, FWS has become a largely applied science organization. We use research results of others to develop management plans, etc. on national wildlife refuges. I feel free to call with further questions/discussion. If research is again in the future of this agency it will take new people, new PDs, new money, etc.training would also be good. Lee, please feel free to call.

(243) I think FWS needs to decide what capacity they want to have to do research. If they want to do research then they should have research positions and reward scientists for their good research.

(244) I strongly urge you to change the climate within the USFWS so that conducting research is valued and supported above the levels today. Right now it seems only research can be conducted by USGS scientists.

(245) Institutional lack of support for publishing in peer-reviewed journals. FWS does not value scientists. Thanks for the opportunity to comment. 11. Despite job being $90 \%$ research, FWS refuses to acknowledge it on paper and keeps my title in management services. Hence, there is no career path for me by conducting research. Publication in peer-reviewed journals is not rewarded or encouraged by FWS. I appealed my title, but lost. Region 6 - fisheries clearly does not want its biologists to be classed as researchers even though in my case, essentially all of my funding comes from the Colorado river recovery program rather than FWS base funds. Part of the problem is that administrators at regional level do not have a research background and do not understand its importance. Also, many decisions within agency are increasingly based on political consideration rather than on sound science, hence, science is under-valued.

(250) I would like to see the FWS moved back towards a more research oriented role in order to provide staff with more hands on application of science in regards to the regulatory documents we generate. Furthermore, I see biological decisions being made by non-scientists or individuals who have lost touch with the scientific method.

Primary category: miscellaneous comments

$9 \%$ of respondents' comments $(23 / 250)$ contained content reflected in this category.

\section{Sub-theme: Research}

(28) You should have a questionnaire about how FWS scientist feel about this current administration's support for science based research.

(58) There are so many imperiled species for which we nothing little about. The field will always have a need for research that informs routine decision-making related to conservation of at risk species.

(65) The law places a high reliance on the professional judgment of field level managers; especially refuge managers (see compatibility policy). In the eyes of some research-oriented personnel with different agendas, that professional judgment is often discounted as unreliable qualitative information.

(122) Within the last 2 years a biologist was added to the staff, station previously did not have a biologist position, we now have someone dedicated to monitoring and collecting data. 
(148) In my opinion, research often fails to provide up-to-date clear answers for practical questions. People who manage moist soil units, forests, or wetlands are biologists, foresters, biotech's, and refuge managers. These people are not going to pull out a scientific article written for scientists, and make a list of tasks they need to do to support habitat management. To be really effective research must be written for the people who do the work at the level where those decisions are being made. If the goal is to provide scientific information that can guide management decisions, the answers must be provided quickly, not years later. Researcher's suggestions on how to manage habitat (based on research they have conducted) should be clear and concise, not vague, ambiguous, or suggestions that to answer that question, another research project should be conducted. Researchers should be receptive to conducting research on relevant topics that will help make management decisions, rather than on what they want to or are accustomed to conducting research on. There comes a time when a decision must be made on where to invest the dollars - on yet another shorebird (for example) research project that will show what we already know - that shorebirds are in great decline due to habitat losses - or on reversing the habitat losses by restoring or protecting habitat to support the species better. Do we need to study the train wreck, or fix the tracks? Since my job is all about habitat, and most species are in decline due to habitat losses or degradation, why not apply the majority of dollars to habitat improvements and restoration? Fund research that is specific to questions that need to be answered to address management issues. Do not fund research projects that study the same issue over and over, or are simply written to obtain publications. Resources are too meager to support research for research's sake.

(150) For large research project there should be the potential to involve all staff in some format and all staff should know what activities are taking place on site or in cooperation with others.

(207) We recently hired a science coordinator who heads our joint venture technical committee and has primary responsibility for research in our office.

(222) NCTC - to - field office. More research but not much. More of a need currently.

(224) Personally, research on my own or with colleagues helped me to better understand the environment and it was very rewarding. In addition, building relationships with experts outside the service is important.

\section{Sub-theme: People who felt the need to comment that they had no comments}
(14) None
(82) No
(191) None
(30) None.
(93) No
(192) None
(81) None
(156) None
(196) None

\section{Miscellaneous}

(33) Good luck!

(134) As always, not enough funding to do mission of protecting trust resources.

(144) See section 6

(158) Cultural hindrances are the hardest to change from the field level and easiest to change from the leadership level.

(210) It would be beneficial to obtain more guides from personal and educational course work by attend meetings of professional society and training classes or college course. 


\section{Appendix 4B. Survey Instrument}

Science in the U.S. Fish and Wildlife Service
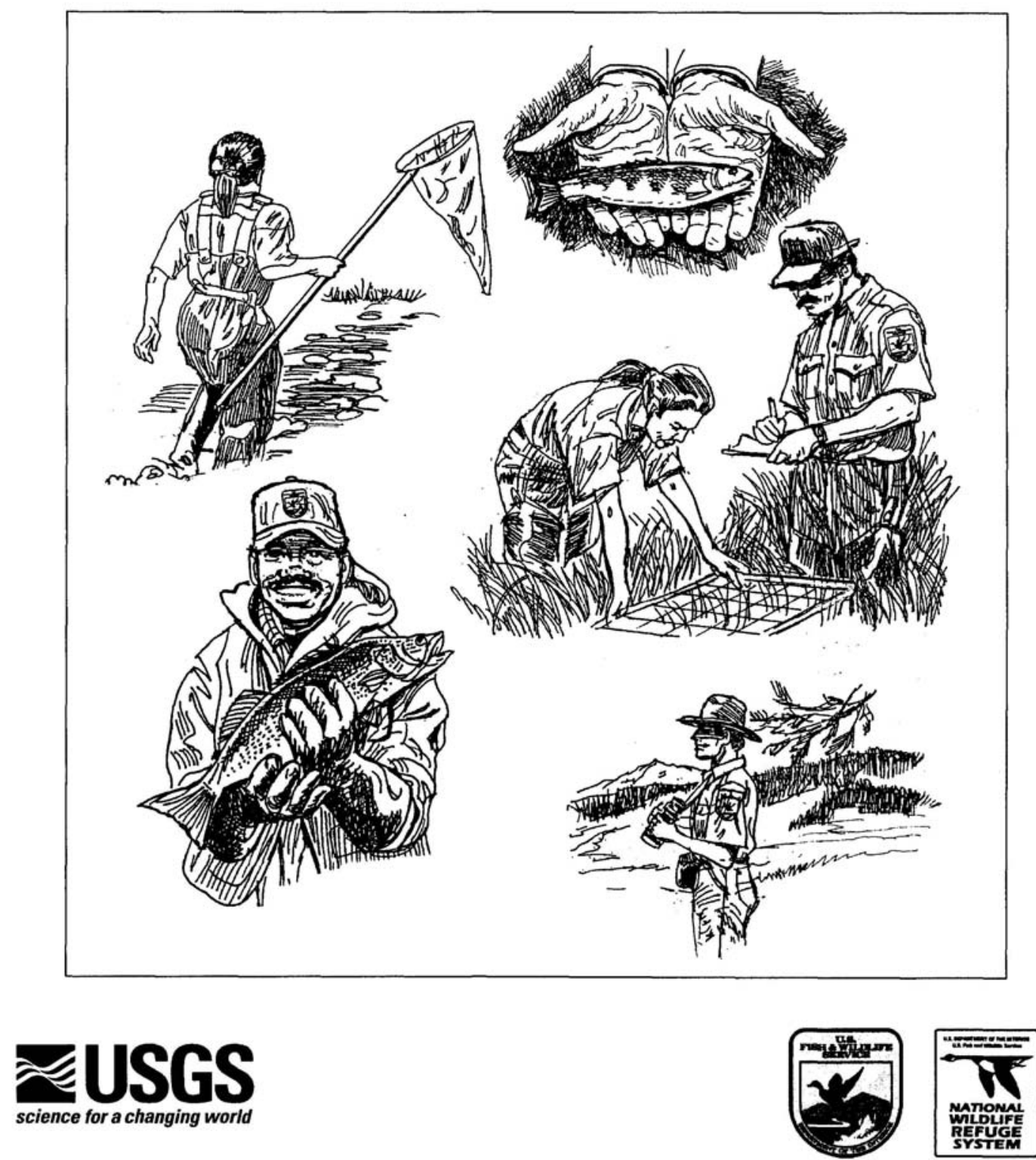
This survey inquires about science in the U.S. Fish and Wildlife Service (FWS). The purpose is to help FWS managers understand the obstacles and inducements to conducting biological, ecological, monitoring studies and research, as well as the scientific capacity of the FWS. Many of the items in this survey will ask about your involvement (or non-involvement) in research activities.

Below is a list of activities that may constitute involvement in research. Please consider these activities and place a check mark by all of the activities that you have performed in your current position with the FWS.

Test hypotheses that further the state of scientific knowledge

Design methods of data collection for research projects

Write research project proposals

Analyze data (statistically or qualitatively)

Write reports of research results

Collect data and use those data to evaluate particular management actions

Collect data and use those data to inform managers or decision-makers who develop plans or policies

Collect data and use those data to provide input to environmental impact statements

Use monitoring data to detect environmental or ecological trends or causes of trends.

Collaborate with individuals from other organizations (e.g., US Geological Survey, universities) on a research project where they may be the Principal Investigator, but you write some portion of the final research output

Supervise or coordinate the efforts of other FWS employees who are engaged in one or more of the research activities listed above

If you placed a check mark by $A N Y$ of the activities listed above, GO TO QUESTION TRACK 1 ON this page.

If you DID NOT place a check mark by any of the activities listed above, GO TO QUESTION TRACK 2 On Page 7.

\section{Question Track 1}

\section{Section 1: The role of research in the FWS.}

\begin{tabular}{|c|c|c|c|c|c|}
\hline & 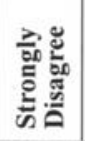 & 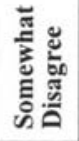 & 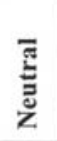 & 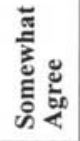 & 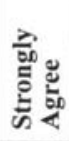 \\
\hline 1. I am expected to conduct research as part of my normal job duties. & 1 & 2 & 3 & 4 & 5 \\
\hline $\begin{array}{l}\text { 2. There is a clear career path leading to advancement for me through } \\
\text { conducting research. }\end{array}$ & 1 & 2 & 3 & 4 & 5 \\
\hline $\begin{array}{l}\text { 3. I am able to obtain the financial resources that are necessary to conduct } \\
\text { research from FWS funds. }\end{array}$ & 1 & 2 & 3 & 4 & 5 \\
\hline 4. My supervisor encourages me to publish research. & 1 & 2 & 3 & 4 & 5 \\
\hline
\end{tabular}




\begin{tabular}{|c|c|c|c|c|c|}
\hline & 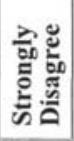 & 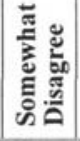 & 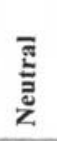 & 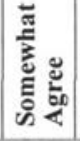 & 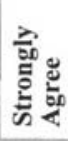 \\
\hline 5. I feel that the FWS encourages me to publish research. & 1 & 2 & 3 & 4 & 5 \\
\hline $\begin{array}{l}\text { 6. I feel comfortable approaching my supervisor when I have questions or } \\
\text { need help regarding my research projects. }\end{array}$ & 1 & 2 & 3 & 4 & 5 \\
\hline $\begin{array}{l}\text { 7. I have been in other positions within the FWS that have been more } \\
\text { supportive of conducting research than my current position. }\end{array}$ & 1 & 2 & 3 & 4 & 5 \\
\hline $\begin{array}{l}\text { 8. I have been in other positions within FWS that have been less supportive of } \\
\text { conducting research than my current position. }\end{array}$ & 1 & 2 & 3 & 4 & 5 \\
\hline $\begin{array}{l}\text { 9. Support for FWS employees to do research has increased in the past } 10 \\
\text { years. }\end{array}$ & 1 & 2 & 3 & 4 & 5 \\
\hline 10. Support for FWS employees to do research has decreased in the past 10 years. & 1 & 2 & 3 & 4 & 5 \\
\hline 11. I feel that the FWS encourages me to get involved in research. & 1 & 2 & 3 & 4 & 5 \\
\hline
\end{tabular}

Section 2: Please tell us about the resources available to you for conducting research.

\begin{tabular}{|c|c|c|c|c|c|c|}
\hline & & 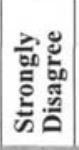 & 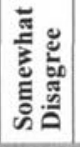 & 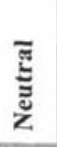 & 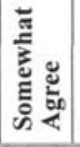 & 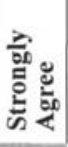 \\
\hline & $\begin{array}{l}\text { I have access to the equipment (e.g., tools, machinery, etc.) I need to } \\
\text { conduct research. }\end{array}$ & 1 & 2 & 3 & 4 & 5 \\
\hline & $\begin{array}{l}\text { I have access to the technology (e.g., computers, tracking devices, etc.) I } \\
\text { need to conduct research. }\end{array}$ & 1 & 2 & 3 & 4 & 5 \\
\hline & $\begin{array}{l}\text { I have access to the computer software (e.g., statistics, etc.) I need to } \\
\text { conduct research. }\end{array}$ & 1 & 2 & 3 & 4 & 5 \\
\hline 4. & I have access to the journals, books, etc. that I need to conduct research. & 1 & 2 & 3 & 4 & 5 \\
\hline & $\begin{array}{l}\text { I have access to the training I need to keep me current in research and data } \\
\text { analysis methods. }\end{array}$ & 1 & 2 & 3 & 4 & 5 \\
\hline & $\begin{array}{l}\text { My supervisor is a valuable resource to me because he or she is } \\
\text { knowledgeable about research. }\end{array}$ & 1 & 2 & 3 & 4 & 5 \\
\hline & $\begin{array}{l}\text { My co-workers are a valuable resource to me because they are } \\
\text { knowledgeable about research. }\end{array}$ & 1 & 2 & 3 & 4 & 5 \\
\hline 8. & I feel that the time necessary to conduct research is made available to me. & 1 & 2 & 3 & 4 & 5 \\
\hline \multicolumn{7}{|c|}{$\begin{array}{l}\text { 9. I am able to obtain the financial resources that are necessary to conduct my } \\
\text { research by partnering with: }\end{array}$} \\
\hline & a. City, county, or state government agencies & 1 & 2 & 3 & 4 & 5 \\
\hline & b. Other federal agencies & 1 & 2 & 3 & 4 & 5 \\
\hline & c. Non-profit agencies & 1 & 2 & 3 & 4 & 5 \\
\hline & d. Private companies & 1 & 2 & 3 & 4 & 5 \\
\hline & e. Universities & 1 & 2 & 3 & 4 & 5 \\
\hline
\end{tabular}


10 Which of the following resources do you use to support research projects? Please indicate the percentage of each totaling $100 \%$ :

\begin{tabular}{l} 
Base operating funds \\
Partnerships with other organizations where no money changes hands \\
Volunteers \\
Research grants obtained independently or through collaboration with others \\
Line-item funds from Congress \\
Reverted federal aid funds \\
Agreements with for-profit organizations, where they provide some or all of the funding \\
Agreements with universities and/or non-profit organizations, where they provide some or all of the \\
funding \\
Agreements with other governments (e.g., state, local), where they provide some or all of the funding \\
\hline $\begin{array}{l}\text { Inter-agency agreements with other federal agencies, where they provide some or all of the funding } \\
\text { Total Research Budget }\end{array}$
\end{tabular}

\section{Section 3: Please tell us about the nature of the research you conduct.}

1. What is the subject or topic of your current or most recent research project? (For example, black-footed ferret reintroduction monitoring, migration, reproduction, fire management, hydrological study of refuge marshes, etc.)

2. What percentage of your job involves research?

$\%$

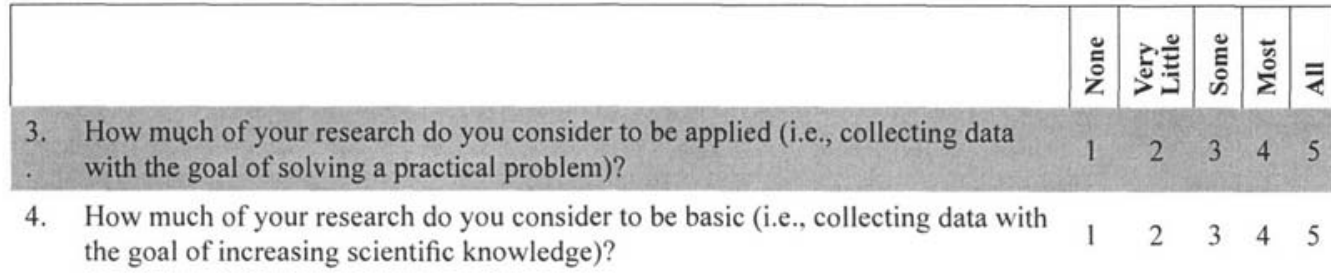
the goal of increasing scientific knowledge)?

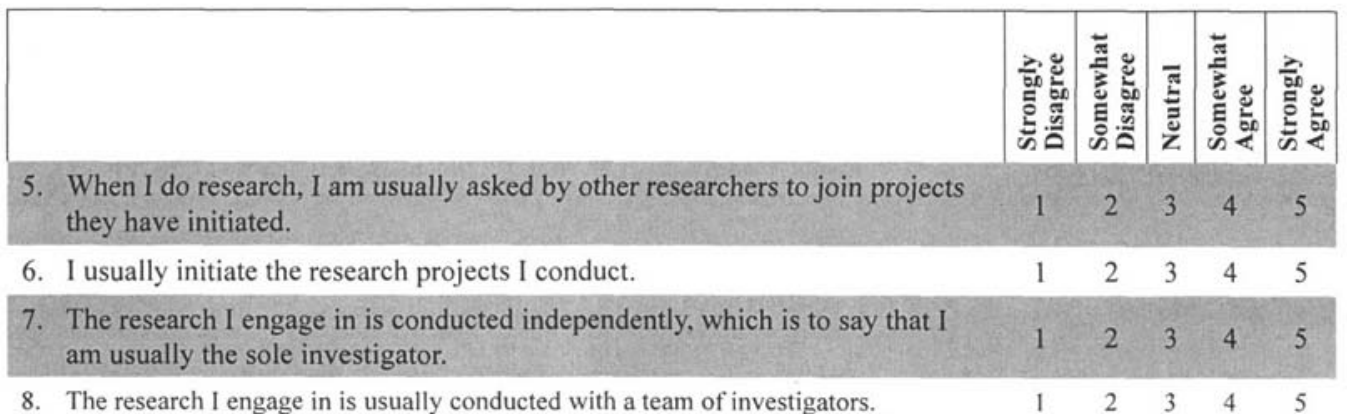


SECTION 4: Please tell us how your research results are reported.

\begin{tabular}{|c|c|c|c|c|}
\hline 1. How frequently do you present the results of your research in the following sources? & $\begin{array}{l}\grave{s} \\
\grave{d} \\
z\end{array}$ & 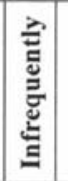 & 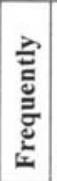 & $\frac{n}{2}$ \\
\hline Publications of the FWS or other government agencies & 1 & 2 & 3 & 4 \\
\hline Peer-reviewed scientific journals & 1 & 2 & 3 & 4 \\
\hline Peer-reviewed professional or trade journals & 1 & 2 & 3 & 4 \\
\hline Non-peer-reviewed magazines & 1 & 2 & 3 & 4 \\
\hline Newspapers or TV media & 1 & 2 & 3 & 4 \\
\hline Web-based media & 1 & 2 & 3 & 4 \\
\hline Scientific symposia or conferences & 1 & 2 & 3 & 4 \\
\hline Chapters in edited books & 1 & 2 & 3 & 4 \\
\hline Sole-authorship books & 1 & 2 & 3 & 4 \\
\hline Multiple-authorship books & 1 & 2 & 3 & 4 \\
\hline FWS internal symposia or conferences & 1 & 2 & 3 & 4 \\
\hline
\end{tabular}

2. There are several possible objectives for publishing or presenting research results. Which would you say best describes your purpose when you publish or present research results? Please check ALL that apply.
$\square$ Provide information to other scientists
$\square$ Provide information for land, water, or wildlife managers
$\square$ Provide information to the general public
Not applicable to me. I do not publish or present research results

\section{SECTION 5: Please tell us how the results of your research projects are used.}

Check ALL of the statements below that apply to you.

In my current position with the FWS, the results of my research have been used to:

\section{Inform myself or other FWS employees of better practices}

Improve policy

Improve government programs

Write environmental impact statements

Advise administrative rule-making, permits, or licenses

Increase the scientific knowledge in my discipline or field

Satisfy a directive of my supervisor 
SECTION 6: Please tell us how you feel about working at FWS.

\begin{tabular}{|c|c|c|c|c|c|}
\hline How satisfied are you with: & 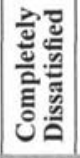 & 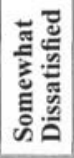 & $\begin{array}{l}\bar{\pi} \\
\text { z } \\
\text { z }\end{array}$ & 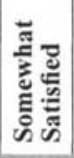 & 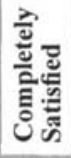 \\
\hline 1. Your current position at the FWS? & 1 & 2 & 3 & 4 & 5 \\
\hline $\begin{array}{l}\text { 2. The weight that is given to research productivity in your performance } \\
\text { evaluations, in your current position at the FWS? }\end{array}$ & 1 & 2 & 3 & 4 & 5 \\
\hline $\begin{array}{l}\text { 3. The level of financial support you receive for research in your current } \\
\text { position? }\end{array}$ & 1 & 2 & 3 & 4 & 5 \\
\hline $\begin{array}{l}\text { 4. The level of encouragement you receive from your supervisor for research in } \\
\text { your current position? }\end{array}$ & 1 & 2 & 3 & 4 & 5 \\
\hline $\begin{array}{l}\text { 5. The amount of research time you have, free from other commitments, in your } \\
\text { current position? }\end{array}$ & 1 & 2 & 3 & 4 & 3 \\
\hline
\end{tabular}

\begin{tabular}{|c|c|c|c|c|c|}
\hline . & 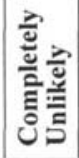 & 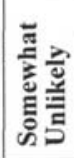 & 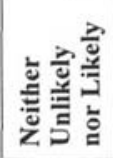 & 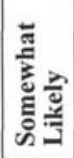 & 专 \\
\hline $\begin{array}{l}\text { 6. How likely are you to begin looking for another job outside of the FWS } \\
\text { in the next six months, due to a lack of opportunity for research in the FWS? }\end{array}$ & 1 & 2 & 3 & 4 & 5 \\
\hline $\begin{array}{l}\text { 7. How likely is it that you would be happier with your job at the FWS if it } \\
\text { included greater opportunities for research? }\end{array}$ & 1 & 2 & 3 & 4 & 5 \\
\hline $\begin{array}{l}\text { 8. How likely is it that you would be happier with your job at the FWS if it } \\
\text { included fewer research obligations? }\end{array}$ & 1 & 2 & 3 & 4 & 5 \\
\hline
\end{tabular}

9. Do you feel that your current position description adequately includes the research you do?

$\square$ Yes or $\square$ No

10. Did you initially seek employment with the FWS because you expected research opportunities?

$\square$ Yes or $\square$ No

11. Is there any other information you would like to provide regarding the support, lack of support, obstacles, inducements, or resources at the FWS with regard to research? If so, please write your answer below:

Please skip Track 2 Questions and answer the

"Final Questions on Page 7" 


\section{Question Track 2}

\section{SECTION 1: Please help us learn more about your attitude toward research at the FWS.}

1. Overall, would you say that your formal education prepared you to conduct either applied (i.e., collecting data with the goal of solving practical problems) or basic research (i.e., collecting data with the goal of increasing knowledge)?

$\square$ Yes $\square$ No

2. Were you hired originally by the FWS solely or in part to do research?

$\square$ Yes $\square$ No

3. If I had a position in the FWS that was rewarded for conducting research, I would be: Please circle one.

$\begin{array}{ccccc}1 & 2 & 3 & 4 & 5 \\ \text { Greatly Less } & \text { Slightly Less } & \text { Neutral } & \text { Slightly More } & \text { Greatly More } \\ \text { Satisfied } & \text { Satisfied } & & \text { Satisfied } & \text { Satisfied }\end{array}$

SECTION 2: Although you do not conduct research yourself, we would like to know if you are involved in the research process in some other way.

1. Do you supervise employees or manage groups of employees who conduct research?

$\square$ Yes $\square$ No

2. Do you or your employees contract outside of the FWS for research to be conducted (such as with private companies, universities, or other agencies)?

$\square$ No

$\square$ Yes, Then what is the major consideration you use in deciding to whom you should award these contracts:

3. Do you use the results of others' research studies in the course of your work?

$\square$ No

$\square$ Yes, What percentage of the following sources of research information do you find most helpful?

Please indicate the percentage of each totaling $100 \%$ :

\begin{tabular}{|c|c|}
\hline & Professional or scientific conferences \\
\hline & Professional or scientific journals \\
\hline & The world wide web \\
\hline & Personal contacts with scientists \\
\hline & Newspaper, TV or other open media sources \\
\hline & Colleagues within the FWS \\
\hline & Colleagues in other agencies (e.g., universities, USGS, etc.) \\
\hline & Reports of other agencies \\
\hline$=100 \%$ & \\
\hline
\end{tabular}




\section{Final Questions}

\section{Please tell us about yourself.}

This information will NOT be used to identify you. It will be aggregated with other data to give us a better understanding of research in the FWS.

1. What is your age? (years)

2. What is your gender? Please check one. $\quad \square$ Male $\square$ Female

3. What is the highest educational degree you have completed? Please check one.

$\begin{array}{ll}\square \text { High school diploma } & \square \mathrm{PhD} \\ \square \text { Terminal occupational program } & \square \text { JD } \\ \square \text { Associate degree } & \square \text { MD } \\ \square \text { Bachelor's degree } & \square \text { Other professional graduate degree } \\ \square \text { Master's degree } & \end{array}$

4. What is your job title and grade?

5. How many years have you worked for the FWS? (years at FWS)

6. What region of the FWS do you work in?

7. Within the past 3 years, have your research responsibilities changed, or have you moved within the FWS to or from a job with more research responsibility? Please check the response that applies.

$\square$ To a job that includes more research responsibilities

$\square$ From a job that included more research responsibilities

$\square$ Remained in current job, but now have added research responsibilities

$\square$ Remained in current job, but now have fewer research responsibilities

$\square$ None of the above apply to me

Please tell us if you have any other comments, suggestions, or information: 


\section{Appendix 4C. Demographic Comparison of Known Publishers v. Other Survey Respondents}

Table 4c.1. Central tendency measure comparison of the age of known publishers v. other survey respondents.

\begin{tabular}{r|cc} 
& Known publishers $(\mathbf{n}=\mathbf{3 6 8})$ & Other survey respondents $(\mathbf{n}=\mathbf{9 2 5})$ \\
\hline Mean & 46.4 & 43.8 \\
Median & 47.0 & 45 \\
Mode & $44,49,50$ (multiple modes) & 50
\end{tabular}

Notes. The $95 \%$ confidence interval for the mean of age of the known publishers ranges from 45.58 to 47.22 ; the $95 \%$ confidence interval for the mean of the age of the other survey respondents ranges from 43.2 to 44.37 . There is no overlap in these two confidence intervals indicating that the average ages of the individuals in the published group and the other survey respondent group are different.

Table 4c.2. Frequency comparison of the gender of known publishers v. other survey respondents.

\begin{tabular}{r|cc} 
& Known publishers $(\mathbf{n}=\mathbf{3 6 8})$ & Other survey respondents $(\mathbf{n}=\mathbf{9 2 5})$ \\
\hline Male & 260 & 591 \\
Female & 106 & 320
\end{tabular}

Table 4c.3. Frequency and central tendency measure comparison of the educational level of known publishers v. other survey respondents.

\begin{tabular}{|c|c|c|}
\hline & Known publishers ( $n=368$ ) & Other survey respondents $(n=925)$ \\
\hline (1)High school diploma & 1 & 4 \\
\hline (2)Terminal occupational & & 3 \\
\hline (3)Associate degree & & 9 \\
\hline (4)Bachelor's degree & 77 & 404 \\
\hline (5)Master's degree & 198 & 432 \\
\hline (6)PhD & 86 & 55 \\
\hline (7)JD & 1 & 1 \\
\hline (8)MD & 1 & 1 \\
\hline (9)Other & 3 & 6 \\
\hline Median & 5.0 & 5 \\
\hline Mode & 5.0 & 5 \\
\hline
\end{tabular}

Notes. Sparsity across the full range of values in the table precluded a chi-square test. A Chi-square using only educational levels 4,5 , and 6 did indicate an association between educational level and known publication status (16\% of BS, $31 \%$ of MS, and $61 \%$ of PhD were known publishers). Treating the data for only educational levels 4,5 , and 6 as interval data (although it may violate some assumptions to do so), the average education level for publishers is 5.06 (95\% confidence interval ranging from 4.98 to 5.14); the average education level for the other survey respondents is 4.6 ( $95 \%$ confidence interval ranging from 4.55 to 4.65 ). These two confidence intervals do not overlap, indicating that the average education level (limited range) between the known publishers and other survey respondents is significantly different.

Table 4c.4. Central tendency measure comparison of the employment tenure of known publishers v. other survey respondents.

\begin{tabular}{r|cc} 
& Known publishers $\mathbf{( n = 3 6 8 )}$ & Other survey respondents $(\mathbf{n}=\mathbf{9 2 5})$ \\
\hline Mean & 15.5 & 11.8 \\
Median & 14 & 10 \\
Mode & 13 & 3
\end{tabular}

Notes. The 95\% confidence interval for the mean of tenure of the known publishers ranges from 14.66 to 16.40 ; the $95 \%$ confidence interval for the mean of the tenure of the other survey respondents ranges from 11.24 to 12.39 . There is no overlap in these two confidence intervals indicating that the average tenures of the individuals in the published group and the other survey respondent group are different. 
Table 4c.5. Frequency and central tendency measure comparison of the Fish and Wildlife Service region of known publishers v. other survey respondents.

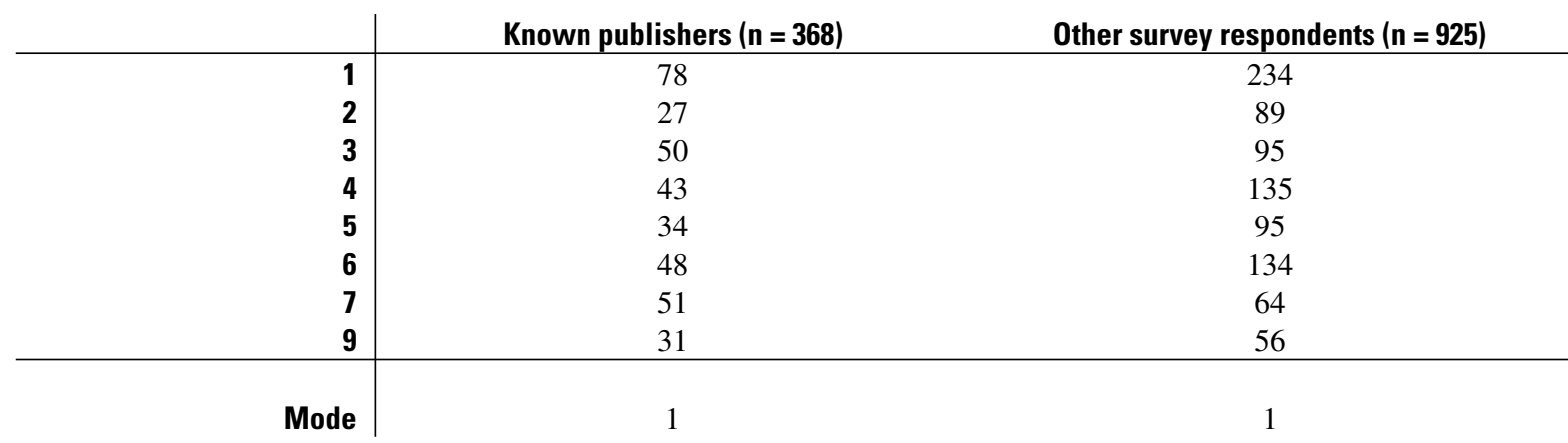

Notes. A Chi-square measure of association indicated a relationship between region of FWS and categorization as a known publisher or not. The actual form of the relationship driving this finding is difficult to determine. Within the known researchers, the greatest percentage came from Region 1 (21.5\%), next highest percentage was from Region 7 (14\%), the lowest was from Region 2 (7.5\%). As far as percentage of known researchers within region, Region 7 had the highest proportion of respondents who were known researchers (44.3\%); the region with the next highest proportion was Region 9 with 35.6\%; the lowest proportion was from Region 2 (23.3\%).

Table 4c.6. Frequency and central tendency measure comparison of responses of known publishers and other survey respondents to the question "Within the past 3 years, have your research responsibilities changed, or have you moved within the Fish and Wildlife Service to or from a job with more research responsibility?"

\begin{tabular}{l|cc} 
& $\begin{array}{c}\text { Known publishers } \\
\text { (n= 368) }\end{array}$ & $\begin{array}{c}\text { Other survey } \\
\text { respondents (n= 925) }\end{array}$ \\
\hline (1) To a job that includes more research responsibilities & 29 & 89 \\
(2) From a job that included more research responsibilities & 53 & 104 \\
(3) Remained in current job, but now have added research responsibilities & 62 & 105 \\
(4) Remained in current job but now have fewer research responsibilities & 42 & 71 \\
(5) None of the above apply to me & 178 & 531 \\
\hline & Mode & 5
\end{tabular}

Table 4c.7. Frequency comparison of known researchers and survey respondents who answered that $50 \%$ or more of their job is research.

\begin{tabular}{l|cc} 
& Known researcher & Other survey respondent \\
\hline $0-49 \%$ of job involves research & $232(24 \%)$ & $521(54 \%)$ \\
$50-100 \%$ of job involves research & $97(10 \%)$ & $120(12 \%)$
\end{tabular}

Notes. This comparison indicates that the group of known researchers and the group of survey respondents who answered that $50 \%$ or more of their job is research are not highly overlapping groups. 